\title{
Scale and Regionality of Nonelectric Markets for U.S. Nuclear Light Water Reactors
}

L. Todd Knighton, Daniel Wendt, Abdalla Jaoude, Cristian Rabiti, and Richard Boardman (INL),

Amgad Elgowainy, Krishna Reddi, and Adarsh Bafana (ANL),

Brian D. James, Brian Murphy, Julia Scheerer, and Fred Peterson (Strategic Analysis)

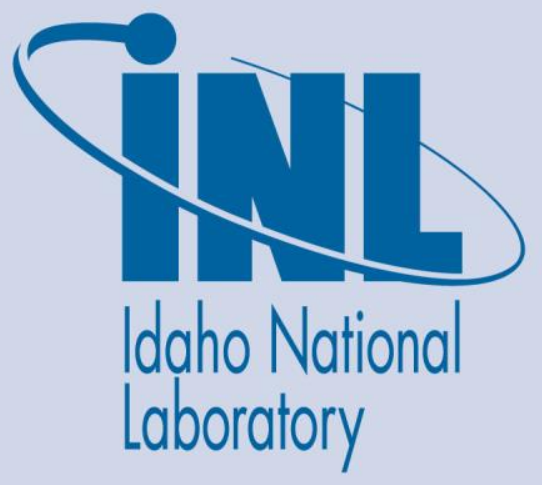

The INL is a U.S. Department of Energy National Laboratory operated by Battelle Energy Alliance 


\section{DISCLAIMER}

This information was prepared as an account of work sponsored by an agency of the U.S. Government. Neither the U.S. Government nor any agency thereof, nor any of their employees, makes any warranty, expressed or implied, or assumes any legal liability or responsibility for the accuracy, completeness, or usefulness, of any information, apparatus, product, or process disclosed, or represents that its use would not infringe privately owned rights. References herein to any specific commercial product, process, or service by trade name, trade mark, manufacturer, or otherwise, does not necessarily constitute or imply its endorsement, recommendation, or favoring by the U.S. Government or any agency thereof. The views and opinions of authors expressed herein do not necessarily state or reflect those of the U.S. Government or any agency thereof. 


\title{
Scale and Regionality of Nonelectric Markets for U.S. Nuclear Light Water Reactors
}

\author{
L. Todd Knighton, Daniel Wendt, \\ Abdalla Jaoude, Cristian Rabiti, \\ and Richard Boardman (INL), \\ Amgad Elgowainy, Krishna Reddi, \\ and Adarsh Bafana (ANL), \\ Brian D. James, Brian Murphy, \\ Julia Scheerer, and Fred Peterson (Strategic Analysis)
}

March 2020

Idaho National Laboratory Idaho Falls, Idaho 83415

http://www.inl.gov 


\section{EXECUTIVE SUMMARY}

Nuclear energy is increasingly being recognized as a valuable low-carbon, low-emissions energy source that can help meet clean energy targets being set by states, commissions, and utilities in the United States. Currently, nuclear power provides about one-fifth of the country's electricity. Nuclear power plants (NPPs) further provide the grid with all-weather season-long baseload capacity that is important to grid reliability and resiliency.

An innovative revenue model that has been proposed for U.S. LWRs is to alternatively use the heat and electricity from nuclear reactors to produce indemand industrial products - hydrogen for use in fuel cell electric vehicles (FCEV), cofiring with natural gas (NG), petroleum and biofuel refining, ammonia production, direct-reduced iron (DRI) for steel production, and synthetic fuels (synfuels) and chemicals (synchems) such as methanol, polymers, formic acid, and others-via thermal and electrochemical processes during seasonal and daily periods of low grid-electricity market pricing (overgeneration) in lieu of being curtailed or producing electricity to the grid at a less-than-optimal electricity price. Repurposing NPPs to flexibly produce nonelectric products and clean-energy carriers could help alleviate the economic pressure on NPPs and enable decarbonization of the power sector, as well as the transportation and industrial sectors.

This study takes an in-depth look into various regions interest (Figure ES1) representing a variety of operating markets, local generation mix, and seasonal climates within the U.S. near existing LWR facilities to identify the scale, location, and accessibility of a wide variety of candidate industrial-product markets, as well as their feedstocks as applicable-for example $\mathrm{CO}_{2}$, as a feedstock to synfuels or formic acid production - that could be accessed by producing these products using the heat and electricity from nuclear reactors. Both current and future market opportunities surrounding these nuclear plants were investigated. Regions were selected where nuclear operating utilities such as Exelon, Xcel Energy, Harbor Energy, Arizona Public Service, Duke Energy, and Southern Company are currently considering nonelectric product possibilities. Other interested utilities and the topics of possible future studies include Nebraska Public Power District and Wolf Creek Operating Corporation. This study shows a large variety of product opportunities open to nuclear plants as they diversify their offerings in addition to producing grid electricity. Electricity capacity markets are also discussed because they reward large and reliable generators, such as nuclear plants, that are able to guarantee allweather/all-season capacity and are important in the mix of alternate revenue sources that will help these nuclear plants to remain profitable and sustainable. Also presented is a sample analysis of the economics of hydrogen production in the Minnesota area, considering the capital and operating costs of the hydrogen plant as well as local market demand for hydrogen. 


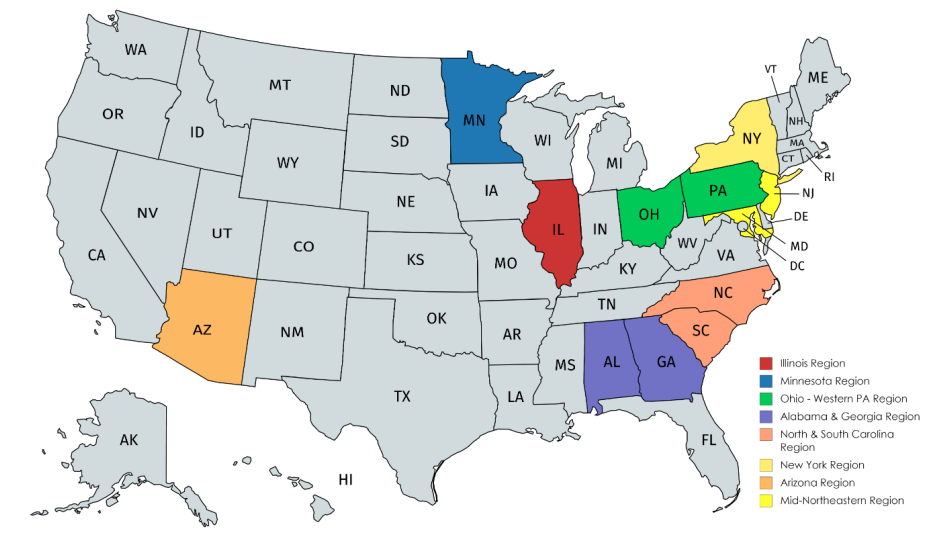

Figure ES1: Regions of study for this report

NPP operators are presented with diverse market options to consider in order to optimize their revenue by economically dispatching electricity either to the grid or to the production of industrial products, fuels, and chemicals.

The objectives of this study include:

- Provide U.S. NPP operators a robust sampling of the market demand location, scale, and accessibility (including storage and transportation) of the wide variety of industrial-product choices that could be produced using thermal nuclear energy and electricity in proximity to a subset of U.S. NPPs to inform the industry of the potential opportunity

- Show examples and trade-off analyses of how U.S. LWR operators can access these markets, including storage and transportation of industrial products to their intended markets

- Present a general analytic example for one industrial product (i.e., hydrogen) in one region (the Minnesota area), including production, storage, and transportation, to show how nuclear-hybrid integrated energy systems (IESs) could access local markets and improve the profitability of a NPP.

It is envisioned that, in the near future, large industrial processes - such as metals refineries, and synfuels and polymers production plants-may choose to advantageously collocate and closely couple with the heat and electricity generated by NPPs in order to fully realize the advantages and synergies of nuclear-hybrid IESs. By collocating industrial-process plants near NPPs, large amounts of thermal and electrical energy produced by a nuclear plant can be efficiently and locally used to produce transportable fungible products such as refined metals and steels, synfuels, polymers, ammonia, formic acid, and others onsite.

This report focuses heavily on direct demand for hydrogen and its use in making other products and chemicals such as DRI for steel production, ammonia and fertilizers, and synfuels etc). Demand for other products such as oxygen, formic acid, polymers and other applications are briefly discussed. An update to demand applications for heat from NPPs to form an energy park as well as more 
in-depth studies of synfuels and chemicals such as methanol coupling with NPPs will be the subjects of future studies. A separate future study will also present analysis of the national discussion around creating a clean energy credit system for electricity and non-electric products produced using nuclear energy and propose various methods for doing so.

This report begins a library of information on the demand market for nonelectric industrial products in these regions. It can inform decisions on the timing and scale of nonelectric product pilot and commercial scale demonstrations for each region. Companies' internal as well as local and state regulator decarbonization targets will play a role in these decisions. The level of clean energy and carbon emissions reduction targets for each organization may highlight additional incentives to couple nonelectric products with NPPs. As expected, carbon emissions lifecycle analyses (LCA) summarized in this report show that using nuclear power instead of fossil fuels to make these industrial products drastically reduces $\mathrm{CO}_{2}$ emissions. Nonelectric product demand data (as presented in this report) is just one dataset needed when doing rigorous modeling in technoeconomic analysis (TEA). Other inputs such as specific electricity grid demand and structure, NPP and nonelectric product process modeling and economic parameters, etc will be collected in future specific TEAs. Individual specific TEAs have been completed for two nuclear plant locations, one for Harbor Energy (Davis-Besse) and one for Exelon (Braidwood). Future TEAs to be completed include Xcel Energy and Arizona Public Service (APS) and others in the future as interest applies. These rigorous TEAs provide modeling results specific to the NPP operator, location, and chosen nonelectric process technology to show the options, configuration, and operating strategies with the most probable success and highest financial and environmental incentives for each location. 


\section{Contents}

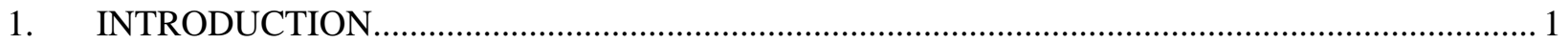

2. INDUSTRIAL PROCESS AND PRODUCT MARKETS OF STUDY ………............................ 4

$2.1 \quad$ Overview of Electricity Capacity Markets..................................................................... 4

2.1.1 Analysis of NPP-Associated Facilities and Capacity Markets.................................... 7

2.2 Electrolysis: Hydrogen and Oxygen Markets …………………………………..... 7

2.2.1 Fuel Cell Electric Vehicles .................................................................................. 8

2.2.2 Co-Firing of Hydrogen with Natural Gas in Combustion Turbines............................ 10

2.2.3 Petroleum and Biorefineries............................................................................... 11

2.2.4 Direct Reduced Iron for Metals Refining and Steel Production ................................ 12

2.2.5 Ammonia and Fertilizers................................................................................... 14

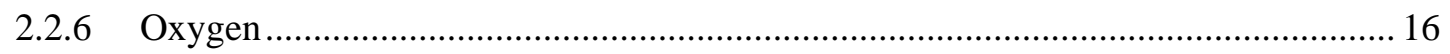

2.2.7 Co-Electrolysis - Carbon Dioxide Reduction with Water ......................................... 18

2.2.8 Summary of Electrolysis Markets.......................................................................... 22

2.3 Electrochemical Monomer Production - Ethylene ………………………………....2 24

2.3.1 Overview of Ethylene and Associated Polymer Markets......................................... 25

2.3.2 Analysis of NPP-associated facilities and the Ethylene Market ............................... 27

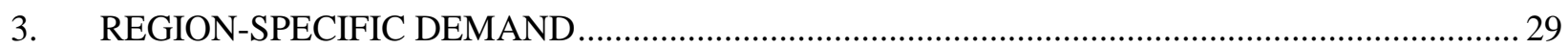

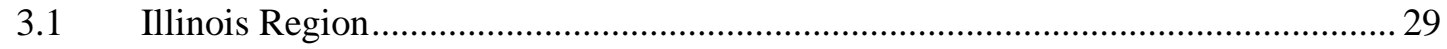

3.1.1 Clinton NPP, Bloomington, IL …………………………………………….... 30

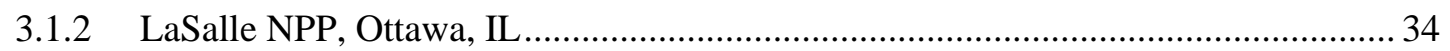

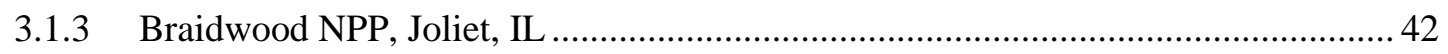

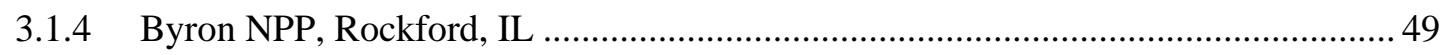

3.1.5 Quad Cities NPP, Moline, IL .......................................................................... 55

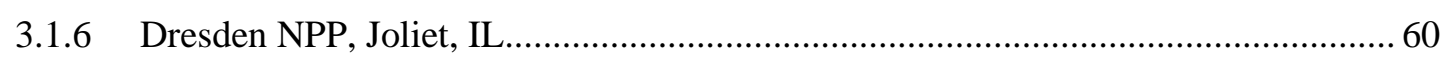

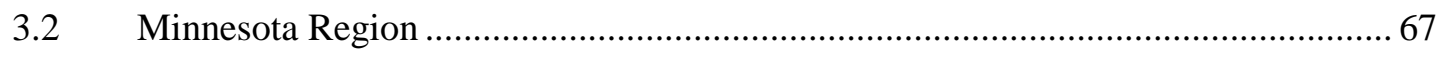

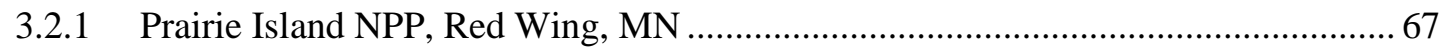

3.2.2 Monticello NPP, Monticello, MN …………………………………………..... 72

3.3 Ohio/Western Pennsylvania Region ...................................................................... 77

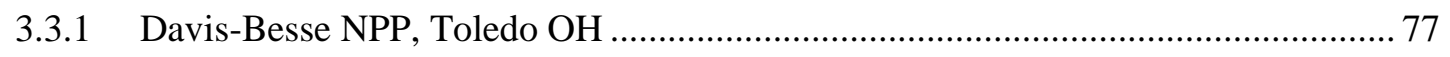

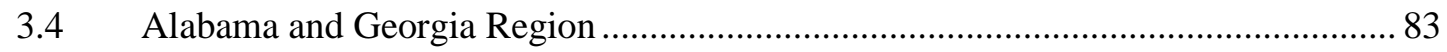

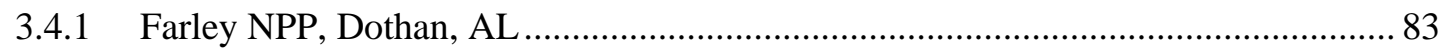

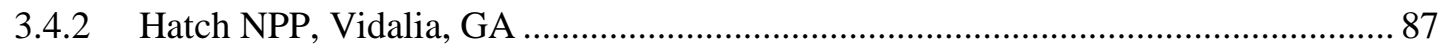

3.4.3 Vogtle NPP, Augusta, GA ……………………………………………...... 92

3.5 Arizona Region ....................................................................................... 97

3.5.1 Palo Verde NPP, Tonopah, AZ …………………………………………...... 97

3.6 North / South Carolina Region.............................................................................. 109

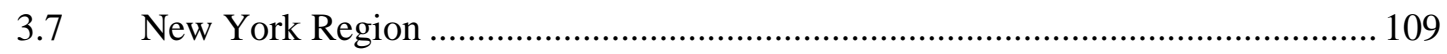

3.8 Mid-Northeastern Region ................................................................................... 110

4. GENERALIZED SAMPLE ECONOMIC ANALYSIS OF HYDROGEN PRODUCTION

COUPLED WITH NUCLEAR ENERGY IN A REGULATED MARKET ……………..........................112 


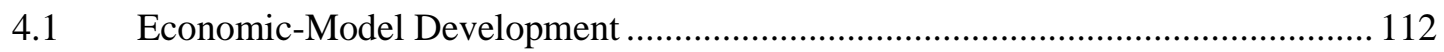

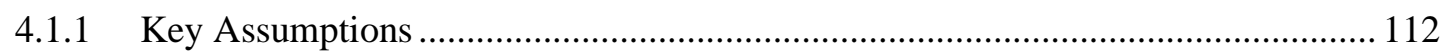

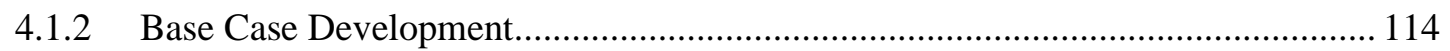

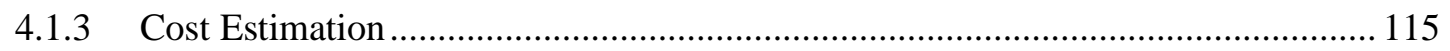

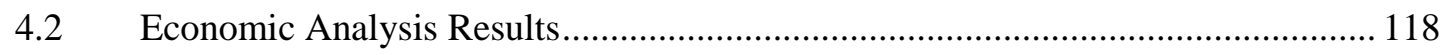

4.2.1 Single Fixed Hydrogen Price ............................................................................. 118

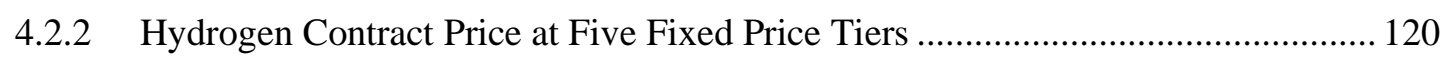

4.2.3 Dynamic Hydrogen Price Market Response ........................................................... 121

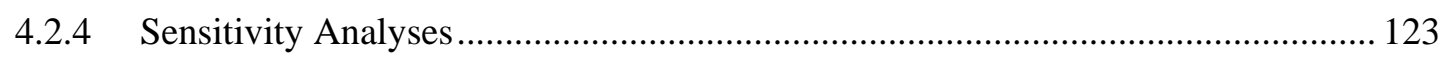

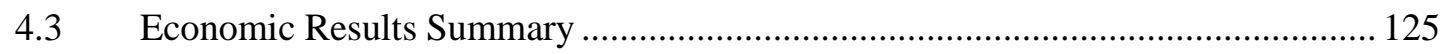

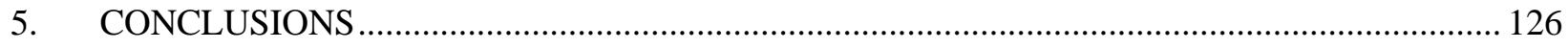

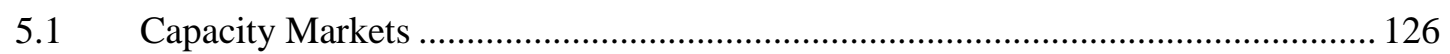

5.2 Markets for Direct Hydrogen and Indirect Hydrogen (DRI, Ammonia, Synfuels),

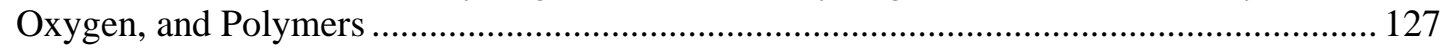

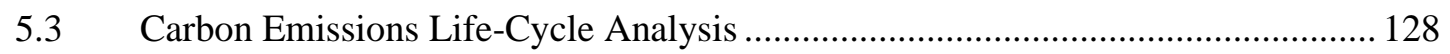

5.4 Regional Demand Analysis........................................Error! Bookmark not defined.

5.5 Nuclear-Hydrogen Hybrid Sample Model Analysis ............................................... 128

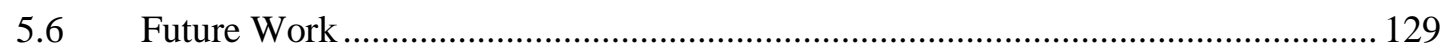

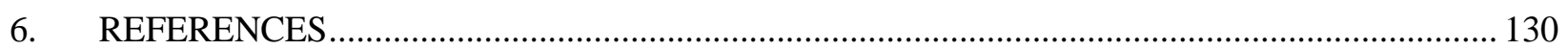

\section{FIGURES}

Figure 1. Integrated Energy System NPP Energy Park Concept ........................................................ 2

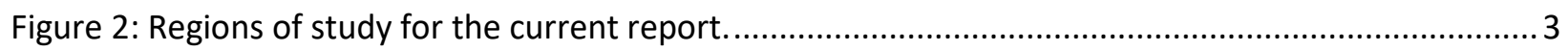

Figure 3. Map of regulated and deregulated electricity and NG markets by state in the U.S. Source: https://energywatch-inc.com/regulated-vs-deregulated-electricity-markets/.............. 5

Figure 4. Map of the current RTOs and ISOs in the U.S. Source:

https://www.ferc.gov/industries/electric/indus-act/rto.asp. ............................................. 6

Figure 5. Contributions to total wholesale cost of energy, capacity, and ancillary services...................... 6

Figure 6. WTW life-cycle GHG emissions results for LDVs.............................................................. 10

Figure 7. WTW life-cycle GHG emissions results for HDVs. ............................................................. 10

Figure 8. Life-cycle GHG emission for NG electricity generators, well-to-wall outlet analysis..................11

Figure 9. Projected total hydrogen demand for U.S. refineries by PADD, through $2050 \ldots \ldots \ldots \ldots \ldots \ldots \ldots \ldots . . . . . . . . . . .12$

Figure 10. LCA of GHG emissions for various steel-making process options......................................... 13

Figure 11. Estimated $\mathrm{H}_{2}$ Demand for U.S. $\mathrm{NH}_{3}$ Production in 2017................................................. 14 
Figure 12. Current and projected hydrogen demand for U.S. $\mathrm{NH}_{3}$ production ${ }^{10}$ ammonia industry [2018] through 2018, and on an assumed annual growth rate of $1 \%$ through 2050). 15

Figure 13. Life-cycle $\mathrm{CO}_{2}$ emission for ammonia-production pathways. 15

Figure 14. Estimated annual demand for enriched oxygen products by major consuming industry in 2019 and 2030, using current CAGR projections. The center bar shows the maximum daily $\mathrm{O}_{2}$ production of a $1 \mathrm{GW}$ NPP-SOEC facility ( $\left.5,500 \mathrm{MT} / \mathrm{d}\right)$... 16

Figure 15. $\mathrm{CO}_{2}$ sources for use in synfuels production. 20

Figure 16. WTW total- $\mathrm{O}_{2}$ emissions for gasoline, jet fuel, diesel and FT fuel (produced using nuclear $\mathrm{H}_{2}$ ). 20

Figure 17. U.S. polyethylene prices by index, 2007-2022 $(2007=100)^{56}$. 26

Figure 18. Seventy-three percent of U.S. and Canada polyethylene demand is within 700 miles of the new Shell plant in Monaca, Pennsylvania, at the center of the above circle.[13] This region covers includes the majority of INL partner NPP facilities.

Figure 19. Location of ammonia plants (blue), oil refineries (purple), and steel mills (red) within 100 miles of the NPP facilities in Illinois. Large filled circles are drawn to indicate a 100-mile radius around each NPP

Figure 20. Cumulative potential hydrogen demand by type and distance near the Clinton power plant. .34

Figure 21 Future potential hydrogen demand near the Clinton power plant. .34

Figure 22. Cumulative potential hydrogen demand by type and distance near the La Salle generating station.

Figure 23 Future potential hydrogen demand near the La Salle NPP.

Figure 24 Cumulative potential hydrogen demand by type and distance near the Braidwood generating station. .48

Figure 25 Future potential hydrogen demand near the Braidwood generating station. 48

Figure 26. Cumulative potential hydrogen demand by type and distance near the Byron generating station. .54

Figure 27 Future potential hydrogen demand near the Byron generating station.

Figure 28. Cumulative potential hydrogen demand by type and distance near the Quad Cities generating station. 59

Figure 29. Future potential hydrogen demand near the Quad Cities generating station. .59

Figure 30. Cumulative potential hydrogen demand by type and distance near the Dresden generating station. 66

Figure 31. Future potential hydrogen demand near the Dresden generating station. .66 
Figure 32 Cumulative potential hydrogen demand by type and distance near the Prairie Island power plant.

Figure 33 Future potential hydrogen demand near the Prairie Island power plant.

Figure 34. Cumulative potential hydrogen demand by type and distance near the Monticello power plant. 76

Figure 35. Future potential hydrogen demand near the Monticello power plant. 76

Figure 36. Location of ammonia plants (blue), oil refineries (purple), and steel mills (red) within 100 miles of the NPP facilities in Ohio and Western Pennsylvania . Shaded circles are drawn to indicate a 100 radius around each NPP.

Figure 37. Cumulative potential hydrogen demand by type and distance near the Davis Besse Power Plant.

Figure 38. Future potential hydrogen demand near the Davis-Besse NPP.

Figure 39. Location of ammonia plants (blue), oil refineries (purple), and steel mills (red) within 100 miles of the NPP facilities in Alabama and Georgia. Large filled circles are drawn to indicate a 100 radius around each NPP.

Figure 40. Cumulative potential hydrogen demand by type and distance near the Farley NPP. 86

Figure 41. Future potential hydrogen demand near the Farley NPP .86

Figure 42. Cumulative potential hydrogen demand by type and distance near the Hatch NPP. 91

Figure 43. Future potential hydrogen demand near the Hatch NPP. .91

Figure 44. Cumulative potential hydrogen demand by type and distance near Vogtle generating station.

Figure 45. Future potential hydrogen demand near the Vogtle generating station.

Figure 46. Cumulative potential hydrogen demand by type and distance near the Palo Verde generating station.

Figure 47. Future potential hydrogen demand near the Palo Verde generating station.

Figure 48. Location of ammonia plants (blue) and steel mills (red) within 100 miles of the NPP facilities in North and South Carolina.

Figure 49. Location of steel mills (red) within 100 miles of the NPP facilities in New York. Large shaded filled circles are drawn to indicate a 100 radius around each NPP.

Figure 50. Location of oil refineries (purple) and steel mills (red) within 100 miles of the NPP facilities in the Mid-Atlantic US.

Figure 51. Impact of fixed hydrogen prices on the overall profitability of the system. 120 
Figure 52. Price of hydrogen as a function of demand for low, medium, and high NG price assumptions (as dictated by the cost of hydrogen production via SMR) ${ }^{1}$.

Figure 53. NPP-HTSE plant NPV as a function of HTSE size, assuming a dynamic hydrogenmarket-price response, based on competition with SMR using NG. Three price points for NG are considered for comparison.

Figure 54. Sensitivity tornado chart of various low/high estimates for the different variables previously considered.

Figure 55. Impact of carbon tax on NPP-HTSE plant NPV curve as a function of HTSE size. Assumes a dynamic market response based on competition with an NG-powered SMR (at medium NG price). 125

Figure $56 . \mathrm{CO}_{2}$ sources for use in synfuels production. 127

Figure 56. Sensitivity tornado chart of various low/high estimates for the different variables previously considered. 


\section{TABLES}

Table 1. Estimated threshold price for hydrogen to replace alternate feedstocks, by application. ..........23

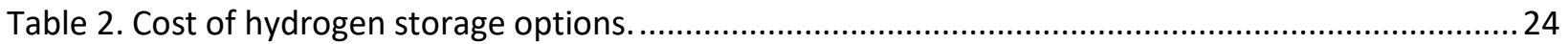

Table 3. Transportation cost of hydrogen using various delivery options. ...............................................24

Table 4 Hydrogen demand within 100 miles of the Clinton Power Plant...............................................31

Table 5 Hydrogen demand within 100 miles of the LaSalle County generating station............................36

Table 6. Hydrogen demand within 100 miles of the Braidwood generating station..................................43

Table 7. Hydrogen demand within 100 miles of the Byron generating station......................................50

Table 8. Hydrogen demand within 100 miles of the Quad Cities generating station...............................56

Table 9. Hydrogen demand within 100 miles of the Dresden generating station..................................61

Table 10. Hydrogen demand within 100 miles of the Prairie Island NPP..............................................68

Table 11. Hydrogen demand within 100 miles of the Monticello NPP.....................................................73

Table 12. Hydrogen demand within 100 miles of the Davis-Besse NPP ................................................79

Table 13. Hydrogen demand within 100 miles of the Joseph Farley NPP. ...............................................84

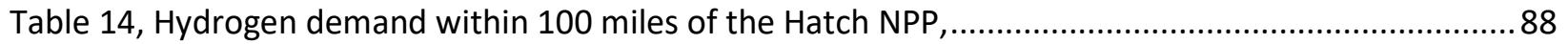

Table 15. Hydrogen Demand within 100 miles of the Vogtle NPP. ......................................................93

Table 16. Hydrogen demand within 400 miles of the Palo Verde NPP ................................................99

Table 17. Estimated range defined for some specific parameters. ..................................................... 113

Table 18. Specifications selected for the fixed parameters................................................................113

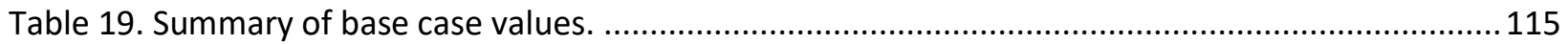

Table 20. HTSE size at which peak NPV is reached (optimal) and the largest HTSE size (maximum)

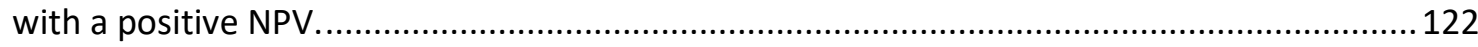

Table 21. NPV for the low and high estimates for the different variables previously considered...........123

Table 22. Impact of carbon tax and NG prices on HTSE economics. ................................................. 125

Table 23. Summary of key findings from the economic model evaluations..........................................126

Table 24. Estimated threshold price for hydrogen to replace alternate feedstocks, by application. ......127

Table 25. Summary of key findings from the economic model evaluations.........................................128 


\section{ACRONYMS}

\begin{tabular}{|c|c|}
\hline ANL & Argonne National Laboratory \\
\hline BOP & balance of plant \\
\hline BWR & boiling water reactor \\
\hline DOE & Department of Energy \\
\hline DRI & direct reduction of iron \\
\hline ENDP & electrolytic non oxidative deprotonation of ethane to form ethylene and hydrogen \\
\hline FCTO & fuel cell technology office \\
\hline HTE & high temperature electrolysis also termed HTSE \\
\hline HTSE & high-temperature steam electrolysis also termed HTE \\
\hline IES & integrated energy systems \\
\hline INL & Idaho National Laboratory \\
\hline LTE & low temperature electrolysis \\
\hline LWR & light-water reactor \\
\hline MED & multi effect distillation \\
\hline NG & natural gas \\
\hline NGCC & natural gas combined cycle \\
\hline NHES & nuclear-renewable hybrid energy system \\
\hline NRC & Nuclear Regulatory Commission \\
\hline NREL & National Renewable Energy Laboratory \\
\hline $\mathrm{OCF}$ & operating capacity factor \\
\hline PE & polyethylene \\
\hline PEM & polymer-electrolyte membrane \\
\hline PFD & process-flow diagram \\
\hline PP & polypropylene \\
\hline PWR & pressurized water reactor \\
\hline $\mathrm{RO}$ & reverse osmosis \\
\hline SOEC & solid-oxide electrolysis cell \\
\hline Syngas & synthesis gas $\left(\mathrm{H}_{2}+\mathrm{CO}\right)$ \\
\hline TBV & turbine bypass valve \\
\hline
\end{tabular}




$\begin{array}{ll}\text { TCV } & \text { turbine control valve } \\ \text { tpd } & \text { tonnes per day } \\ \text { TRL } & \text { technology readiness level } \\ \text { UI } & \text { University of Idaho } \\ \text { WGS } & \text { water gas shift } \\ \text { WSC } & \text { Western Services Corporation }\end{array}$




\section{INTRODUCTION}

Nuclear energy is increasingly being recognized as a valuable low-carbon, low-emissions energy source that can help achieve clean energy targets being set by states, commissions, and utilities in the United States. Currently, nuclear power provides about one-fifth of the country's electricity. Nuclear power plants (NPPs) further provide the grid with all-weather season-long baseload capacity that is important to grid reliability and resiliency. Light water reactor (LWR) NPPs in the United States, like other sources of electricity generation, are facing increasing market competition from natural-gas combined-cycle (NGCC) power plants due to historically low-priced natural gas (NG) associated with the U.S. shale gas boom. As of January 2020, six NPPs have been shut down, mainly due to economic considerations. Future closures of other plants have been announced and appear imminent unless the electricity market changes or unless new markets for these plants can be established. Therefore, the U.S. Department of Energy (DOE) Light Water Reactor Sustainability (LWRS) Program is addressing flexible plant operations that can diversify the revenue of NPPs.

LWRs can independently produce steam and electricity at a competitive cost most of the year because the capital investment associated with these plants has been retired, and the cost of producing power with these reactors is being reduced through plant modernization, extending the life of the plant through materials assessments and enhanced protection, improvements to the fuel and fuel cycle, and implementation of advanced security systems. An innovative revenue model that has been proposed for U.S. LWRs is to alternatively use the heat and electricity from nuclear reactors to produce in-demand industrial products - hydrogen for use in fuel cell vehicles, cofiring with NG, petroleum and biofuel refining, ammonia production, direct-reduced iron (DRI) for steel production, and synthetic fuels (synfuels) and chemicals (synchems) such as methanol, polymers, formic acid, and others - via thermal and electrochemical processes during seasonal and daily periods of low grid-electricity market pricing (overgeneration) in lieu of being curtailed or sending electricity to the grid at a less-than-optimal electricity price. Repurposing NPPs to flexibly produce nonelectric products and clean-energy carriers could help alleviate the economic pressure on NPPs and enable decarbonization of the power sector, as well as the transportation and industrial sectors. Previous studies have shown this can help increase the revenue of the power plants ${ }^{102}$.

Solar and wind can arguably be used to produce industrial products during overgeneration. Two factors provide nuclear power economic advantages over intermittent renewable energy in producing nonelectric products. First, the steady output of nuclear power allows high capacity factors for the equipment that produce nonelectric products to assist in recovering their capital costs. Second, nuclear power also provides large amounts of thermal energy that can increase the efficiency of thermal or electrothermal processes. One example process is production of hydrogen using solid oxide electrolysis cells (SOECs) via electrochemical high-temperature steam electrolysis (HTSE). Some thermal energy from an NPP could be extracted and integrated with the HTSE plant to substantially increase electrolysis process efficiency. Ammonia plants and refineries currently consume around 10 MMT of hydrogen a year in the U.S. A large share of this hydrogen is provided by the merchant market and is delivered to the plants through hydrogen pipelines. But there is a strong drive in the U.S. and globally to increase hydrogen production for large scale transportation and other industrial applications, such as iron and steel manufacturing. In addition, the energy from NPPs can provide steam to industries which are currently located near the NPPs or to companies that may choose to locate new facilities near nuclear plants to form an energy park.

A wide variety of products can be produced using thermal and electrochemical processes that are closely coupled to NPPs. Some of the leading options are shown in Figure 1. A few of these options are already under active consideration for demonstration at nuclear facilities. This report focuses heavily on demand for hydrogen in and of itself and for use in making other products and chemicals (DRI, ammonia, 
etc.). Demand for other products, such as oxygen, formic acid (FA), and other applications are briefly discussed. An update to demand applications for heat from NPPs to form an energy park as well as more in-depth studies of synfuels coupling with NPPs and clean-energy credits for nonelectric products produced from coupled NPP plants will be the subjects of future studies.

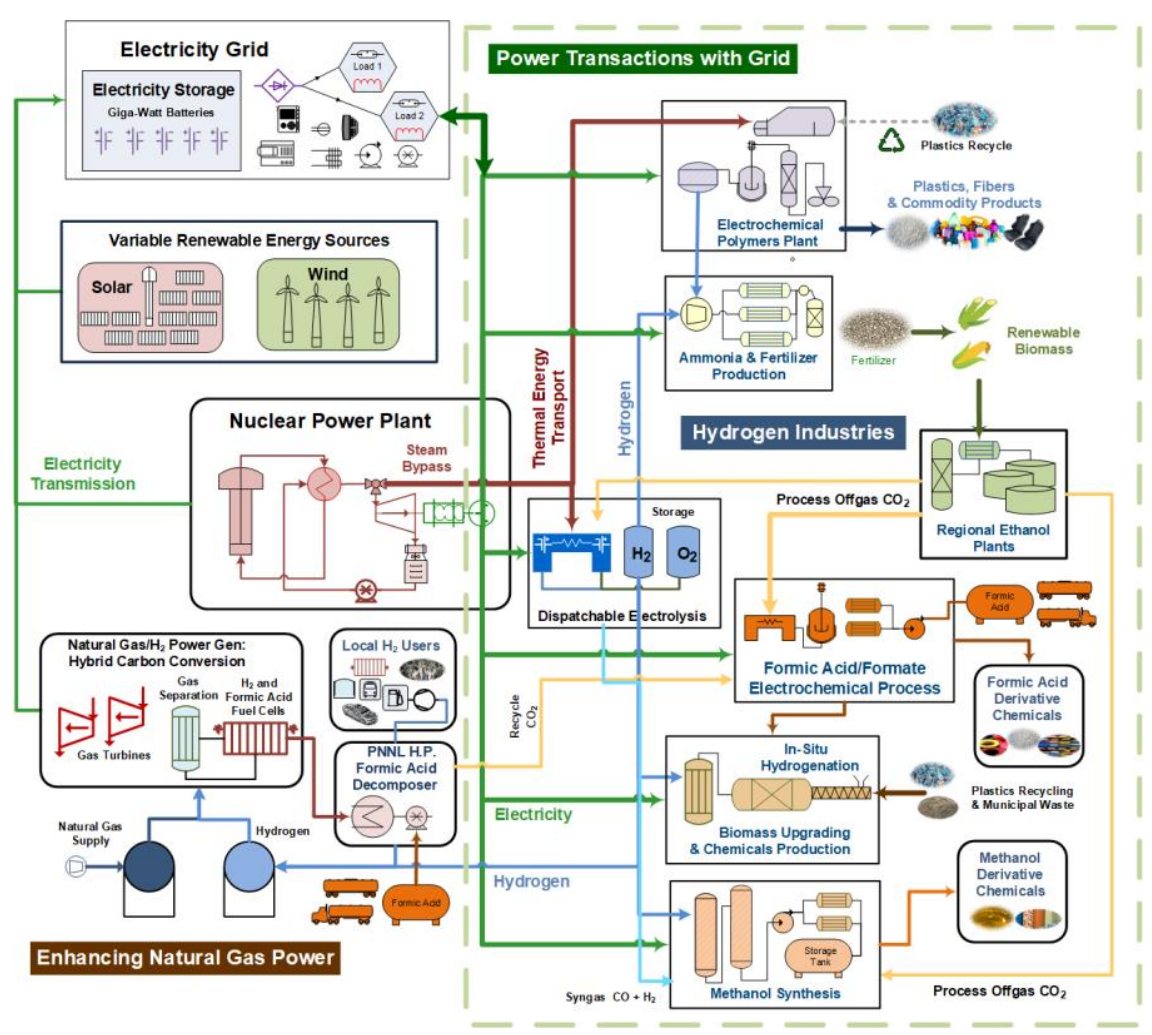

Figure 1. Integrated Energy System NPP Energy Park Concept

This study assesses existing and potential industries that could conceivably be directly coupled to existing nuclear reactors. The goal is to identify the scale, location, and accessibility of the candidate industrial-product markets, as well as process feedstocks that are available near the plants to establish new industries. For example, $\mathrm{CO}_{2}$ as a feedstock can be combined with $\mathrm{H}_{2}$ to produce $\mathrm{FA}$, transportation fuels, and lubricants. These new plants can be entirely supported with the heat and electricity provided by a nearby NPP. The potential demand for nonelectric industrial products was assessed by documenting current and possible growth of nonelectric product markets considered. This assessment used DOE- and industry-supported tools, data, and projections to capture regional industrial market opportunities. Electricity-capacity markets that reward large and reliable generators, such as NPPs, were considered because the electricity market will likely continue to be an important revenue source to NPPs. The key is to balance the needs of energy customers so as to optimize revenue for the affiliated energy customers or partners. In most cases, flexible plant energy delivery and power generation for the grid will require either energy storage or a stock of intermediate products to sustain the industrial customers when the NPP dispatches electricity to the grid.

A diverse mix of regions with operating NPPs around the U.S.- representing a variety of operating markets, local generation mix, and seasonal climates-were chosen for this market study. Both current and future market opportunities for candidate industrial-product markets surrounding these NPPs were studied. Figure 2 illustrates the regions chosen for this study. 


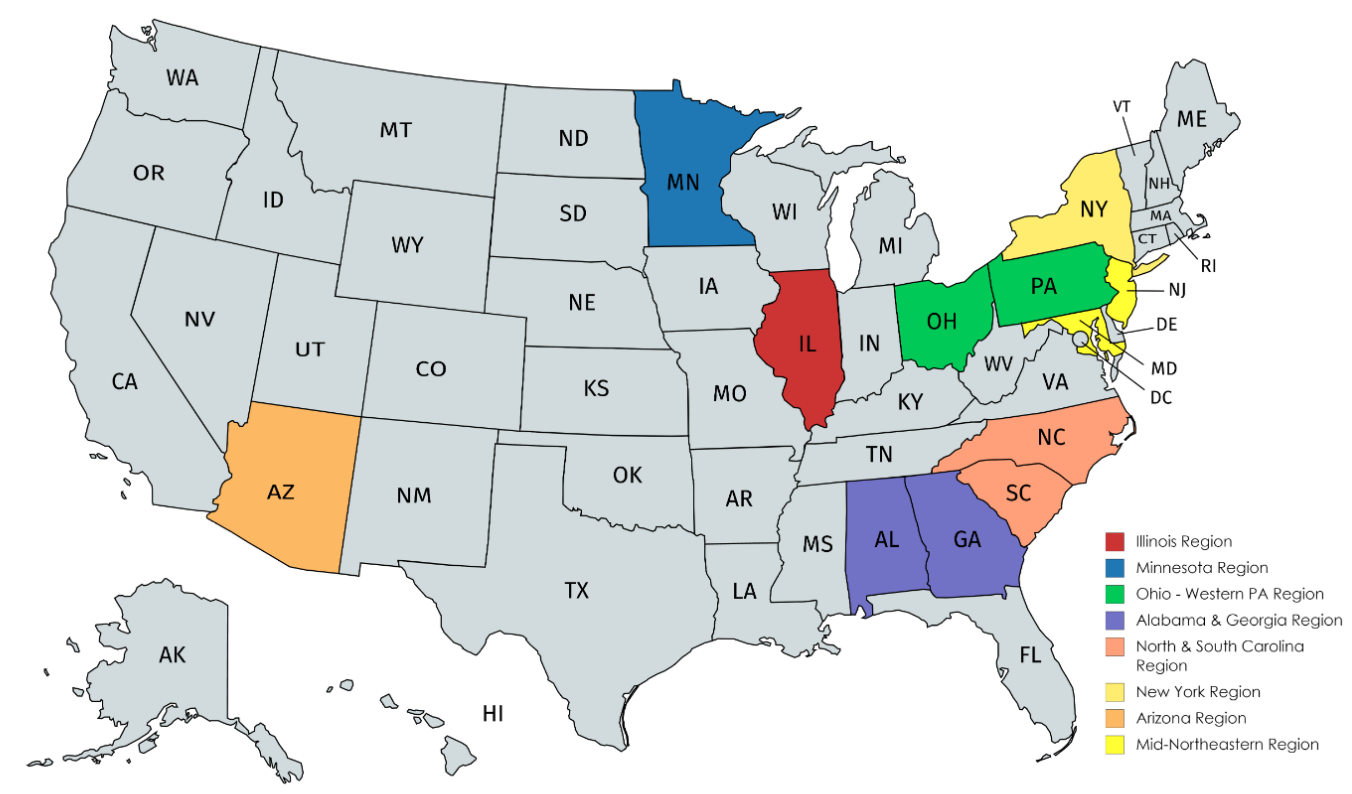

Figure 2: Regions of study for the current report.

The success of developing nonelectric industrial-product markets as alternative revenue-generating sources for LWRs depends, not only on demand from growing existing markets, such as petroleum refining and $\mathrm{NH}_{3}$ production, but also on the development of new markets such as light-duty (LD) and heavy-duty (HD) hydrogen FCEVs, synfuels, chemical production, biofuels, metal refining, injection of hydrogen into NG pipelines for gas power-generating units, FA, polymers, and close-coupled industrial heat applications, all of which can significantly increase demand relative to current levels while decarbonizing energy sectors.

This study also presents a sample analysis of the economics of hydrogen production in an area of Minnesota, considering the capital and operating costs of a hydrogen plant as well as the local market demand for hydrogen. It includes some assumptions on electricity-grid pricing, showing how hydrogen could be integrated with an NPP and be competitive with the incumbent hydrogen-production process, steam methane reforming (SMR).

The objectives of this study include:

- Provide U.S. NPP utilities a robust sampling of the market demand location, scale, and accessibility (including storage and transportation) of the wide variety of industrial-product choices that can be produced using nuclear thermal energy and electricity proximate to a subset of U.S. NPPs to inform the industry of the potential opportunity

- Show examples and trade-off analyses of how U.S. LWR operators can access these markets, including storage and transportation of industrial products to their intended markets

- Present a general analysis example for one industrial product (hydrogen) in one region (Minnesota area), including production, storage, and transportation, to show how nuclear-hybrid integrated energy systems (IESs) could access local markets and improve the profitability of an NPP. 
Due to their potentially large costs, it will be important to minimize product storage and transportation costs by producing fungible and transportable products to the extent possible and by colocating industries close to NPPs. This study includes some discussion on the trade-offs between electricity transmission and distributed production of industrial products versus onsite production of industrial products and their storage and transportation costs. It is envisioned that, in the near future, large industrial processes - such as metals refineries and synthetic-fuel and polymer production plants - may choose to collocate advantageously and to couple closely with the heat and electricity generated by NPPs in order to fully realize the advantages and synergies of nuclear-hybrid IESs. By collocating industrial process plants near NPPs, large amounts of thermal and electrical energy produced by a nuclear plant can be efficiently and locally utilized to produce transportable fungible products, such as refined metals and steels, synfuels, polymers, ammonia, FA, and others, onsite.

\section{INDUSTRIAL PROCESS AND PRODUCT MARKETS OF STUDY 2.1 Overview of Electricity Capacity Markets}

Electricity-capacity markets exist to provide a free-market mechanism to ensure adequate electricity supply during periods of unusually high demand. The capacity markets function by providing guaranteed payments to generators that are able to guarantee on-demand additional electric capacity, whether that capacity is used or not. They represent an additional revenue stream for NPPs to remain connected to the power grid while providing energy to a separate production plant. It should be noted that U.S. electricitycapacity markets are a complicated and changing mix of public and private utilities, government regulators, and customers. They are subject to regulation by both state and federal agencies and appear to be in a considerable state of flux due, in part, to price pressures from increasing deployment of intermittent renewable electricity generation. The variability of markets across the U.S. means that the best economic choice for each NPP varies depending on location. This section will briefly summarize electricity-capacity markets and project reasonable revenue assumptions for various locations.

Regions studied are located in states with both "regulated" and "deregulated" electricity markets (Figure 3). In regulated states, the electric utilities are either vertically integrated — owning generation, distribution, and transmission facilities - or they negotiate bilaterally for access to these facilities. The utility negotiates with the state to project demand requirements and set prices to deliver a regulated rate of return. Thus, risk is spread across the entire portfolio of the utility ${ }^{1}$. In "deregulated" markets, electricity generation, distribution, and market management are undertaken by separate entities, usually a hybrid of public and private interests. Electricity retailers, which sell and distribute to customers, purchase electricity wholesale from generators on markets that are set up and managed by a regional transmission organization (RTO) or independent system operators (ISOs). There are seven RTOs and ISOs in the U.S. (Figure 4). Eighteen NPPs within three of these RTOs and ISOs are selected as the basis for the market analysis: Mid-continent ISO (Monticello, Prairie Island, and Clinton), PJM RTO (Dresden, Braidwood, LaSalle, Byron, Quad Cities, Davis-Besse, Perry, Beaver Valley, Salem, Limerick, Calvert Cliffs, Beach Bottom), and NY-ISO (Ginna, James FitzPatrick, and Nine Mile Point). 


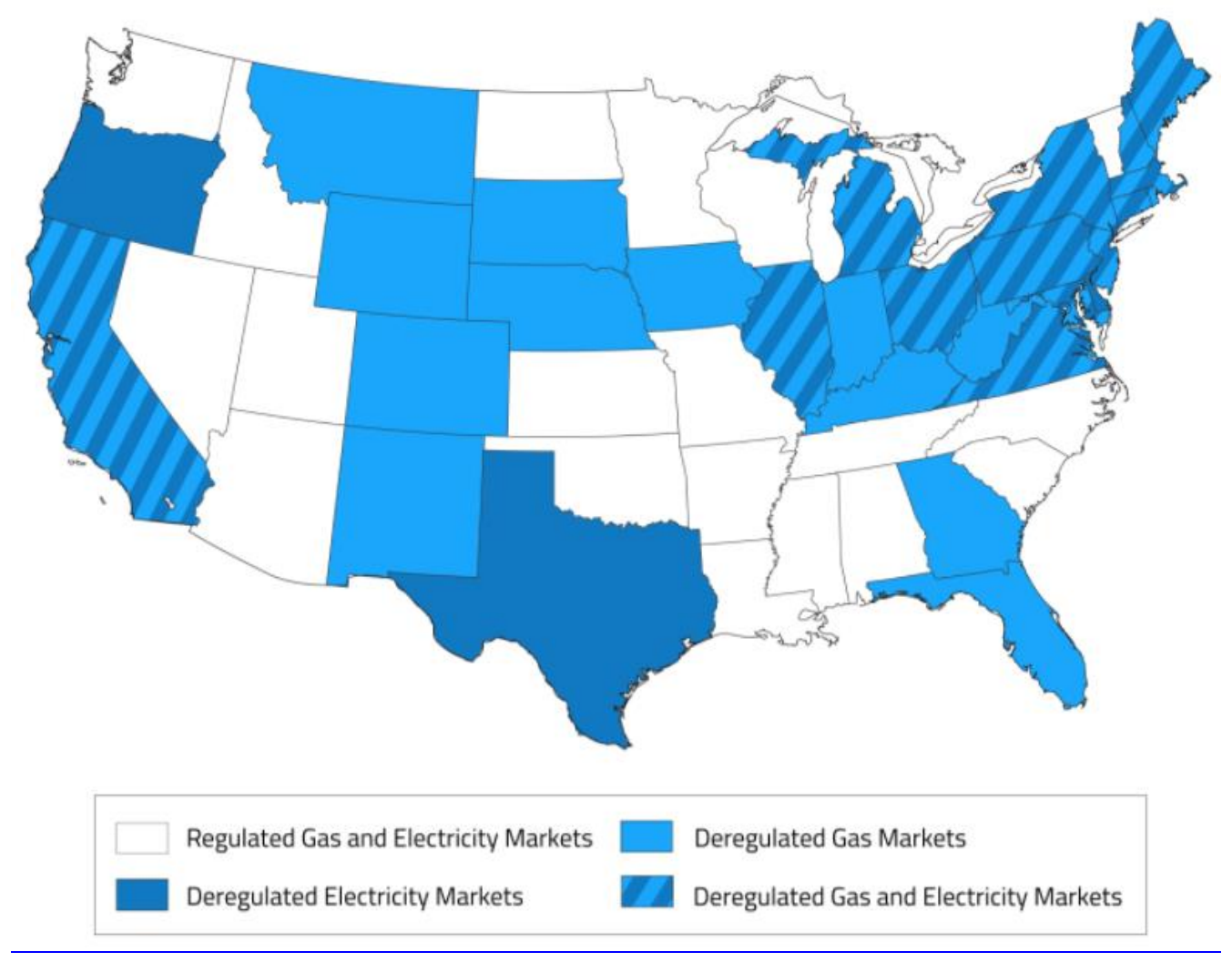

Figure 3. Map of regulated and deregulated electricity and NG markets by state in the U.S. Source: https://energywatch-inc.com/regulated-vs-deregulated-electricity-markets/.

Capacity markets are operated by the MISO, PJM, and NY-ISO RTOs, and are intended to incentivize generators to construct sufficient supply to meet electricity demand at all times. Overseen by the Federal Energy Regulatory Commission (FERC), each regional market operates somewhat differently. All capacity markets pay generators for the ability to deliver electricity, and levee penalties for nonperformance in the event that electricity is requested and not provided. The required capacity is determined by adding a reserve market (often $\sim 15-20 \%$ ) to projected peak demand ${ }^{2}$. Prices are determined by forward-looking auctions, conducted up to 3 years in advance in the PJM region. All those in the market receive the "clearing price,"- that is, the highest bid among units that satisfies the required capacity. Thus, intermittent reserves and other non-baseload suppliers can rely on a steady revenue stream separate from volatile spot-energy prices. These auction-determined transactions are often used as benchmarks for negotiations or evaluations of prices in near-term wholesale or other available markets. This process is sometimes called "price discovery."3 Capacity payments are a significant contributor to electricity prices and utility-value propositions: in 2017, the values of the NE-ISO and PJM capacity markets were $\$ 2.2$ billion and $\$ 8.6$ billion, respectively. It has been estimated that $\sim 10 \%$ of a homeowner's electricity bill can be directly attributed to capacity payments (Figure 5). 


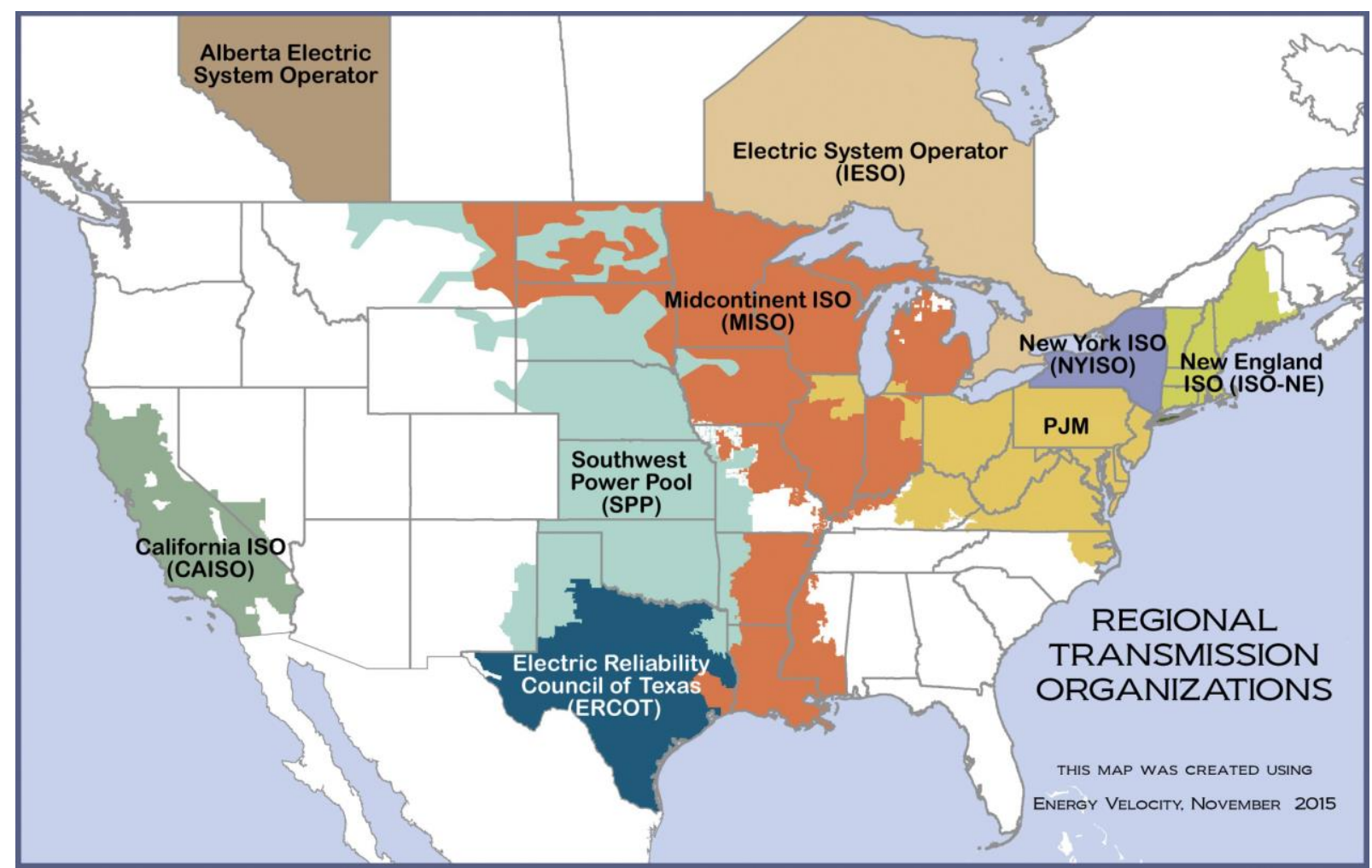

Figure 4. Map of the current RTOs and ISOs in the U.S. Source: https://www.ferc.gov/industries/electric/indus-act/rto.asp.

In addition to generators' bidding in capacity, some RTOs (including PJM) provide incentives for demand reduction at times of high stress or system outages. PJM, through a demand-response program, considers pledges to reduce consumption as equal to pledges to increase generation. Thus, curtailmentservice providers (CSPs) pool retail or industrial customers and receive a "capacity payment" for this pool pledging to reduce their electrical load if asked. CSPs seek to spread the risk of load reduction around a large pool of customers.

Data from prior capacity auctions in the MISO, PJM, and NY-ISO regions shows that capacitymarket prices can vary significantly both regionally and over time. In 2019, capacity auction-clearing prices were \$24.30/MW-day in Minnesota ${ }^{4}$, \$100/MW-day in $\mathrm{PJM}^{5}$, and \$50-125/MW-day in NY-ISO (depending on the specific location) ${ }^{6}$. Recent clearing prices in PJM have fluctuated from a minimum of \$76.50/MW-day for 2020-2021 to \$171.30/MW-day for 2021-2022.

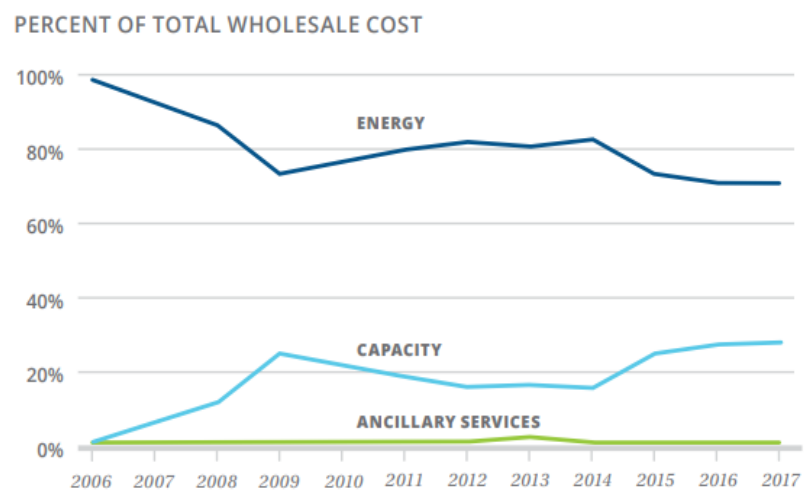

Figure 5. Contributions to total wholesale cost of energy, capacity, and ancillary services. 


\subsubsection{Analysis of NPP-Associated Facilities and Capacity Markets}

The future of capacity markets is uncertain due to scrutiny from both industry and regulators about the fundamental purpose and fairness of the markets. A recent report suggests that mandatory capacity markets lead to large reserve margins, which translates to more than $\$ 1 \mathrm{~B}$ each year paid by customers in PJM, NY-ISO, and NE-ISO for roughly $35 \mathrm{GW}$ of excess capacity, which is unused and unnecessary. Further, incumbent utilities that operate fossil-fuel burning plants are able to lobby RTOs to implement rules that work against renewable power sources or demand response ${ }^{7}$. On the other hand, state policies that seek to incentivize the construction of wind- and solar-power facilities can skew the market unsustainably. FERC commissioners have noted these and other concerns, stating that capacity markets are "untenably threatened" by increasing state subsidies for renewable generation sources ${ }^{8}$. Uncertainty about the appropriate rules (particularly minimum price offer floors) and regulations surrounding capacity markets have prompted FERC to delay the 3-year-ahead PJM capacity auction since August 2019, with no set date for the auction to occur ${ }^{7}$. The governor of Illinois has signaled a willingness to push Illinois out of the PJM region in order to meet state renewable-energy targets, further complicating the future picture $^{9}$. This uncertainty makes it difficult to project an appropriate capacity payment revenue stream for NPPs over the next 10 years.

In addition to the future of capacity markets themselves, accessing capacity markets requires a flexible electricity-demand source that can be quickly switched on and off. RTOs generally require capacity sources to supply electricity within a short time frame, e.g., 10 minutes, when requested. Thus, an NPP-associated electrolysis demand source must be able to ramp down production rapidly and possibly unpredictably. This type of flexible operation introduces supply-chain concerns and costs that may limit the profitability of the capacity payments. During a capacity event, solid oxide electrolysis cells (SOEC) production would necessarily be curtailed. While the SOEC plants may be able to ramp up and down quickly (when starting from a hot temperature), downstream $\mathrm{H}_{2}$ demand processes may not be as flexible. A large $\mathrm{H}_{2}$ demand source - e.g., an ammonia plant - is not typically cycled on and off and thus requires a continuous supply of $\mathrm{H}_{2}$ feedstock. Onsite $\mathrm{H}_{2}$ storage with hundreds (or even thousands) of metric tonnes of capacity would therefore be required to ensure consistent nonelectric industrial-product delivery rates. In regions or during times of year when capacity pricing is low, storage and interruption costs would significantly diminish or outweigh the benefits of capacity payments received from RTOs.

In summary, capacity payments represent an attractive revenue stream, particularly in regions such as PJM, where market prices have recently been as high as $>\$ 100 / \mathrm{MW}$-day. However, capacity prices have proven to be volatile, and are under regulatory scrutiny as they increase as a fraction of the total wholesale electricity cost (Figure 5). The future rules, functionality, and prices of the PJM capacity market are unclear as of the publication of this report. Further, the large generating capacity of some nuclear plants (particularly those over $2 \mathrm{GW}$ ) may overwhelm the capacity market in some regions (e.g., NY-ISO's heavily segmented market), reducing prices or only allowing only a fraction of the NPP capacity to be bid into the market. In addition, the storage and intermittency costs implied by electricitycapacity production should be modeled and explicitly incorporated into revenue analyses.

\subsection{Electrolysis: Hydrogen and Oxygen Markets}

Water electrolysis is the splitting of water into hydrogen and oxygen and is not a new process. New processes, components, methodologies, and materials are constantly being developed in order to reduce the cost and improve the efficiency of the electrolysis process. Currently two technologies exhibit advantages for hydrogen production throughout at least the next decade. The first option is lowtemperature electrolysis (LTE) that uses polymer electrolyte membranes (PEMs) with the hydrogen ion being the motive ion through the electrolyte. The second option is high-temperature steam electrolysis (HTSE) using SOEC with the oxygen ion being the motive ion through the solid oxide electrolyte. HTSE has the potential to give nuclear power an edge in that some thermal energy from the nuclear reactor can be used to increase the electrical efficiency of the electrolysis process. In future decades, other options 
may be preferred. For example, co o-electrolysis is another process being studied and improved. In coelectrolysis, $\mathrm{CO}_{2}$ is also taken as an input to the process along with water. The products are $\mathrm{CO}, \mathrm{H}_{2}$, and $\mathrm{O}_{2}$. $\mathrm{CO}$ and $\mathrm{H}_{2}$ as a mixture is called synthesis gas or syngas because these two molecules can be used in a large number of processes to synthesize fuels (synfuels) and chemicals (synchems). Another future option is higher temperature proton conducting electrolyte (PCE) cells in which the hydrogen, instead of the oxygen ion, moves through the electrolyte. PCE cells have the advantage that they can operate at lower temperatures with reduced degradation and less costly materials of construction; however, they still require laboratory development to achieve their potential.

\subsubsection{Fuel Cell Electric Vehicles}

Hydrogen demand for FCEVs is expected to increase as FCEVs penetrate the light-, medium-, and heavy-duty vehicle markets. Currently, FCEVs are a small share of the vehicle fleet, mainly concentrated in California due to the presence of hydrogen-fueling infrastructure and other state incentives for FCEVs. Because of regional differences in FCEV policy support, the national-level FCEV market share derived from the selected vehicle-choice model were adjusted for each region by moving FCEV market share forward or back in time on the basis of published technology roadmaps, targets, or other official support for zero-emission vehicles (ZEVs) in that region. This determination was somewhat subjective based on the available information on perceived tendency of each region to adopt FCEVs.

As a result, FCEV market penetration first becomes significant in the Western region, followed by the Northeast or ZEV/Eastern region, and then by the three other regions.

Estimates of FCEV light-duty vehicles (LDVs), i.e., car and light-duty truck (LDT), sales, stock and $\mathrm{H}_{2}$ consumption were developed according to the following steps:

1. Total estimated FCEV market penetration and sales: Estimated FCEV LDV and LDT sales were obtained from prior U.S. DOE Fuel Cell Technologies Office (FCTO) analyses consistent with FCTO price targets for delivered H2. Annual numbers of FCEVs sold were derived by applying these estimated sales to U.S. Energy Information Agency (EIA) forecasts of national LDV sales by year.

2. Regional estimated FCEV market penetration and sales: National LDV and LDT sales were allocated to regions to estimate regional FCEV market penetration and sales consistent with the national estimates of FCEV LDV and LDT sales by year as well as regional targets (where applicable).

3. Total and regional estimated FCEV stock and hydrogen use: Regional FCEV LDV and LDT stock, vehicle miles travelled (VMTs), and $\mathrm{H} 2$ consumption were estimated by year and summed to produce national totals.

In accordance with the Government Performance and Reporting Act (GPRA), each year FCTO estimates the impact of its program from the present through $2050^{10}$. Metrics like energy use, emissions, and ownership cost are calculated on the basis of an analysis of market performance using DOEsupported vehicle choice models, which estimate the market shares of conventional internal-combustionengine vehicles (ICEVs), FCEVs, hybrid electric vehicles (HEVs), battery-electric vehicles, and plug-in hybrid electric vehicles (PHEVs) at various range capabilities ${ }^{10}$. Several of these models were run, assuming not only that FCTO's FC cost and performance targets will be met (i.e., the "Program Success" case in FCTO's annual GPRA reporting ${ }^{10}$ ), but also that the retail price of $\mathrm{H}_{2}$ will drop from an estimated $\$ 8.70 / \mathrm{kg}$ currently to within the FCTO's target $\mathrm{H}_{2}$ price range.

Argonne's VISION model uses historic annual sales, survival rates by vehicle age, and age-dependent usage profiles for several technologies to simulate vehicles' utilization, fuel use and emissions through their eventual retirement. The model estimates vehicle stock, VMTs, energy use, and emissions for each vehicle technology. VISION also estimates upstream energy use in feedstock and fuel production. For this 
analysis, annual region-level sales were aggregated to national estimates of medium- and HD vehicle FCEV and conventional technology sales were decreased to keep total medium- and HDV sales the same as in Annual Energy Outlook $2017^{11}$.

For LDVs and LDTs the VISION model was used to estimate annual vehicle stock by technology and vintage in order to estimate regional VMTs and energy use by FCEVs. VISION estimates potential energy use, oil use and carbon-emission impacts of advanced LD- and HD vehicle technologies and alternative fuels. Two scenarios within the VISION model were used for LDVs and LDTs representing low and high potential hydrogen prices, which correspond to high and low FCEV shares of sales. For this analysis, "low" FCEV sales scenario was used. It is based on what was considered a moderate assumption regarding future hydrogen pricing (hydrogen production cost of $\$ 2.2(2015 \$) / \mathrm{kgH}_{2}$ resulting in a hydrogen pump price of $\$ 5(2015 \$) / \mathrm{kgH}_{2}$, including intermediate storage and transportation needed. The regional vehicle forecasts from the VISION model were related to five U.S. regions: western, central industrial, eastern/ZEV states, central southern, and the rest of the U.S.

For M/HDV FCEVs, market share is based on the California Air Resources Board's (CARB) ${ }^{12}$ (2016) projections of market share of ZEVs, together with assumptions regarding the share of those which are FCEVs and assumptions regarding the adoption rates in other states. The share of potential hydrogen demand for MDVs and HDVs is small compared with that of LDVs and LDTs by 2030. For this study, we allocated FCEV hydrogen demand estimates by region ${ }^{18}$ to states and counties based on population by U.S. Census Bureau ${ }^{13}$ and estimated distances from the generating stations based on the county center of population ${ }^{14}$. Like LDVs, the regional vehicle forecasts from the VISION model were related to five U.S. regions: western, central industrial, eastern/ZEV states, central southern, and the rest of the U.S.

The greenhouse-gas (GHG) emissions associated with hydrogen production and the delivery and dispensing pathway can be estimated using a well-to-wheels (WTW) analysis with the Argonne National Laboratory's (ANL's) Greenhouse gas, Regulated Emissions, and Energy use in Transportation (GREET) 2019 model to conduct the life-cycle analysis (LCA). The WTW analysis can be further broken down into well-to-pump (WTP) and pump-to-wheels (PTW) stages. The WTP stage includes fuel production from the primary source of energy (feedstock) to its delivery to the vehicle's energy storage system (fuel tank). The PTW stage includes fuel consumption during the operation phase of the vehicle to power the vehicle's wheels. The results from WTP and PTW analyses are summed to give the WTW energy use and GHG emissions associated with various vehicle-fuel technologies. WTW analysis was carried out using the GREET 2019 model for LDVs, including FCEVs, using various hydrogen-production and delivery pathways and baseline gasoline internal combustion engine vehicles (ICEVs). Fuel economy of $26 \mathrm{mpg}$ was assumed for gasoline ICEVs and 55 mpgge (miles per gallon gasoline equivalent) for $\mathrm{H}_{2} \mathrm{FCEVs}$. Conventional internal combustion engines (ICEs) using gasoline and diesel were compared to FCEV's using hydrogen produced from NG SMR and nuclear electricity.

The WTW equivalent $\mathrm{CO}_{2}$ emissions per mile for LDVs compared ICEVs using gasoline, FCEVs using hydrogen from SMR and FCEVs using nuclear- $\mathrm{H}_{2}$. An ICE using gasoline produces $387 \mathrm{~g}$ $\mathrm{CO}_{2}$ eq/mile, while FCEV using $\mathrm{H}_{2}$ from SMR produces $170 \mathrm{~g} \mathrm{CO}_{2} \mathrm{eq} / \mathrm{mile}$, and FCEV using $\mathrm{H}_{2}$ from nuclear electricity produces only $33 \mathrm{~g} \mathrm{CO}_{2} \mathrm{eq} / \mathrm{mile}$, on a WTW basis (Figure 6).

The WTW eq $\mathrm{CO}_{2}$ emissions per mile for HDVs were also compared. The conventional HD ICEV using diesel in compression-ignition direct-injection engine produces $1.7 \mathrm{~kg} \mathrm{CO}_{2} \mathrm{eq} / \mathrm{mile}$, the HD FCEV using $\mathrm{H}_{2}$ from SMR produces $0.8 \mathrm{~kg} \mathrm{CO}$ eq/mile and the $\mathrm{HD} \mathrm{FCEV} \mathrm{using} \mathrm{nuclear-} \mathrm{H}_{2}$ produces $0.1 \mathrm{~kg}$ $\mathrm{CO}_{2} \mathrm{eq} / \mathrm{mile}$ (Figure 7). 


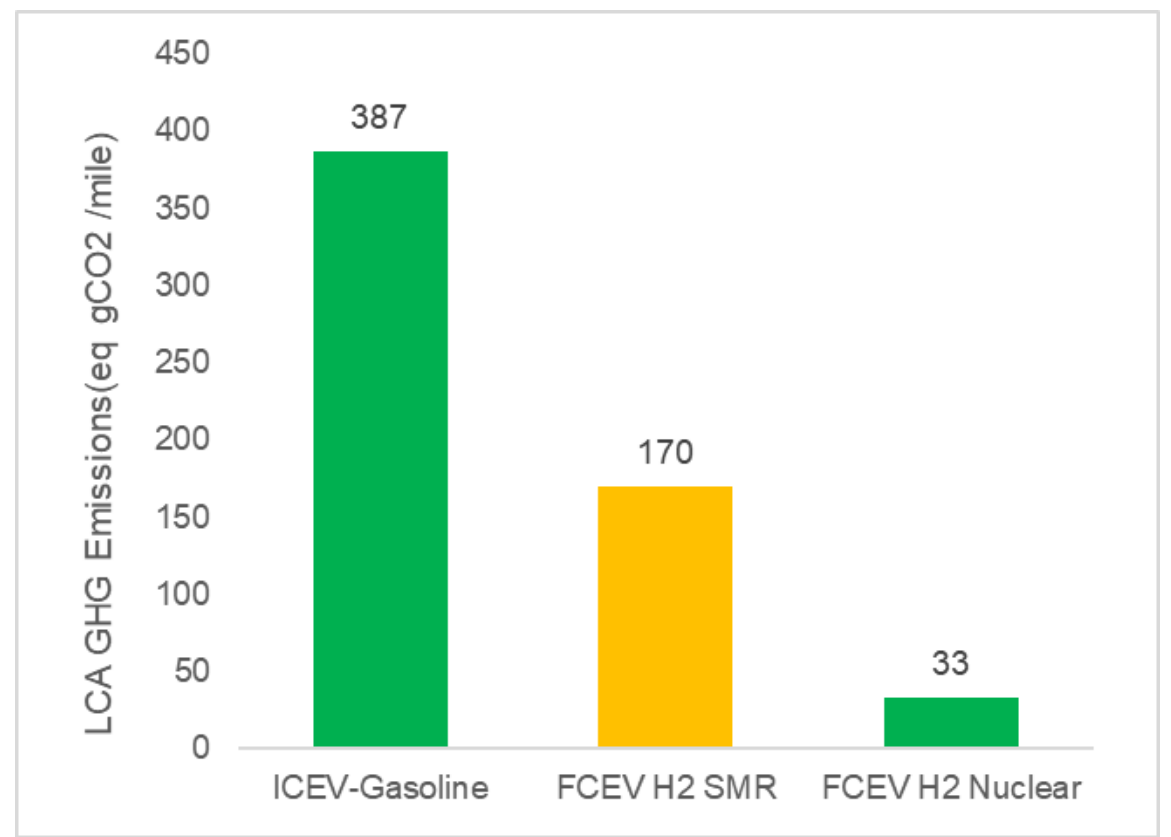

Figure 6. WTW life-cycle GHG emissions results for LDVs.

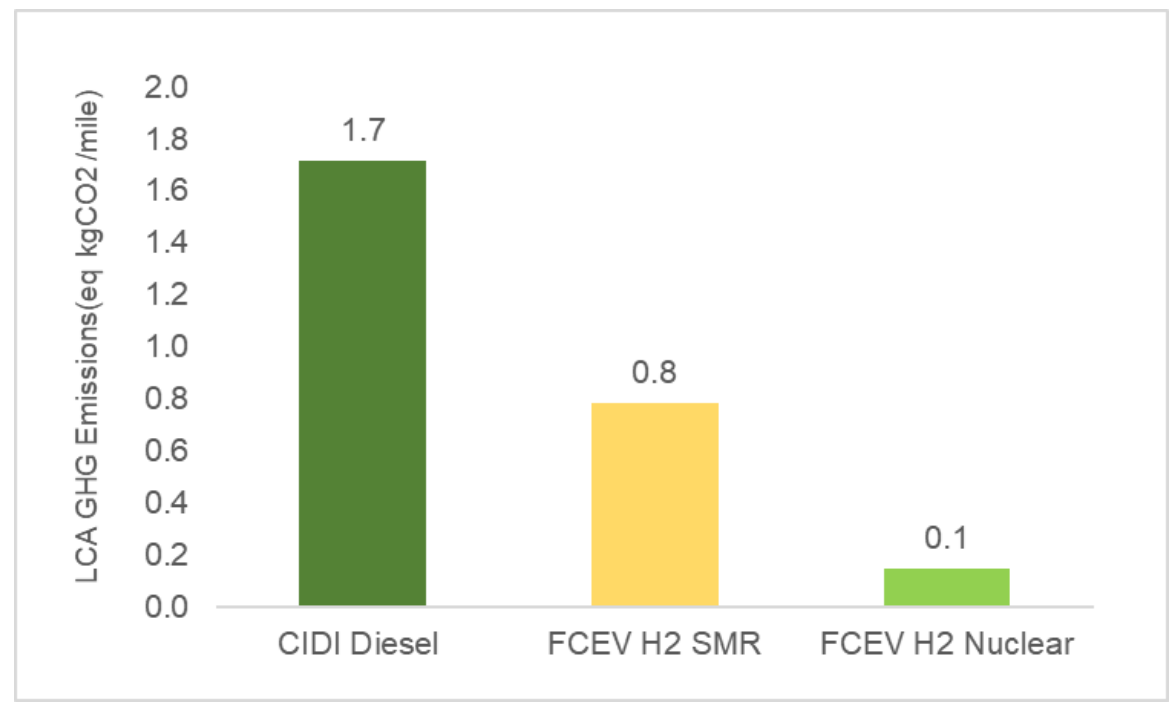

Figure 7. WTW life-cycle GHG emissions results for HDVs, including combustion ignition direct injection (CIDI) diesel engines.

\subsubsection{Co-Firing of Hydrogen with Natural Gas in Combustion Turbines}

Another potential use of clean hydrogen produced from nuclear energy is its injection into NG pipelines for use as a low-carbon green component of an NG-hydrogen fuel mix for general heating use or for exclusive use in CTs. The potential and barriers to mixing $\mathrm{H}_{2}$ with $\mathrm{NG}$ is discussed elsewhere ${ }^{18}$. For the purposes of this study, potential demand is estimated for hydrogen assuming it can be used by NG CTs with a volume ratio of $30 \%$ hydrogen blended with $70 \%$ NG. Electricity generators were identified using the datasets from the EIA-860 and EIA-923 forms describing electricity-generator facility locations and fuel use. The LCA was carried out using the GREET 2019 model to estimate GHG emissions for $100 \%$ NG, as well as a mixture of $30 \%$ hydrogen and $70 \%$ NG by volume, as fuel supply to the electricity generators. The equivalent $\mathrm{CO}_{2}$ emissions per $\mathrm{kWh}$ of electricity produced and transmitted to end use 
(i.e., at the wall outlet) are compared in Figure 8. The life-cycle GHG emissions are estimated at $425 \mathrm{~g}$ $\mathrm{CO}_{2} / \mathrm{kWh}$ when using only NG as the feed, and $390 \mathrm{~g} \mathrm{CO}_{2} / \mathrm{kWh}$ for the mixture of $30 \%$ hydrogen and $70 \% \mathrm{NG}$ by volume. We note that $30 \mathrm{vol} \% \mathrm{H}_{2}$ with $\mathrm{NG}$ represents only $\sim 9 \%$ blending by energy because the volumetric heating value of hydrogen is approximately $30 \%$ of the corresponding heating value of NG. Although, the potential GHG-emission reduction for this mixing ratio appears small, the amount of potential $\mathrm{CO}_{2}$ abatement is significant due to the large contribution of NG generating plants to the U.S. national GHG-emissions inventory. Furthermore, future turbine designs that can handle higher mixing ratios, and potentially combust $100 \%$ hydrogen, will have the potential to eliminate $\mathrm{CO}_{2}$ emissions from gas power-generation units. We also note that mixing hydrogen with NG in the near term is attractive compared to other new hydrogen end-use applications because it leverages the existing NG infrastructure and application end use (i.e., the gas turbine); thus, little new capital investment is needed. The "NG electricity generators" in the demand analysis section of this report is the hydrogen demand calculated for each of these electricity generators assuming they use a mix of $30 \% \mathrm{H}_{2}$ with $\mathrm{NG}$.

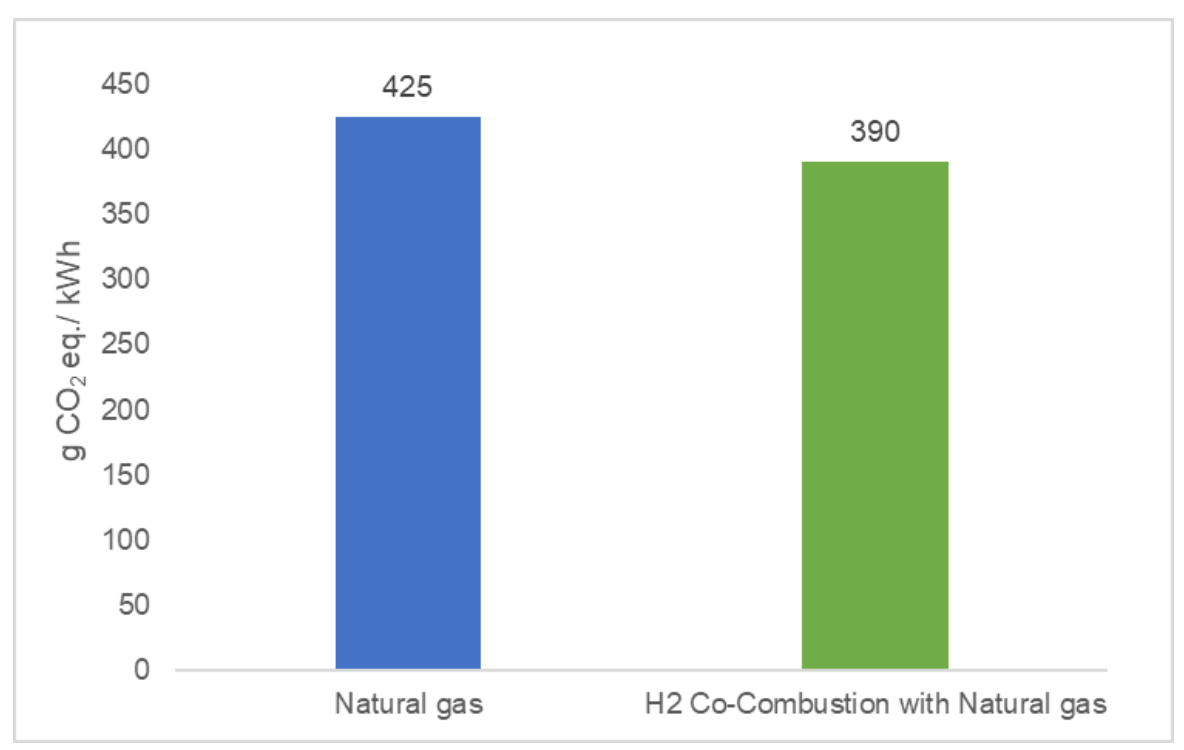

Figure 8. Life-cycle GHG emission for NG electricity generators, well-to-wall outlet analysis.

\subsubsection{Petroleum and Biorefineries}

Petroleum refineries are currently the most significant user of hydrogen in the U.S., consuming approximately 10 MMT of hydrogen annually, including byproduct hydrogen from naphtha reformers ${ }^{15}$. Approximately one-third of refinery hydrogen used is the byproduct of naphtha reforming processes while most of the rest of the needed hydrogen is typically produced onsite using the SMR process with NG as the feedstock. Some refineries also use hydrogen regional pipelines, which are mostly limited to the Gulf Coast in the U.S. The hydrogen is used primarily for hydrocracking and hydrotreating (hydrocracking is used to produce diesel from heavy crude, and hydrotreating is used to remove sulfur from feed, intermediate, and product streams). Most hydrotreating capacity is used for reducing sulfur in diesel, fluid catalytic cracker feeds, and naphtha streams. Refinery hydrogen demand is, in general, driven by the ratio of gasoline to diesel production, API gravity, sulfur content of the petroleum inputs, and the complexity of refinery processing.

Elgowainy and colleagues ${ }^{18}$ estimated future hydrogen demand through 2050 for petroleum refining, based on projections of crude inputs and market demand for refinery products from the EIA Annual Energy Outlook ${ }^{11}$, and crude API gravity and sulfur content based on Han and colleague's analysis ${ }^{16}$. The main conclusions are that crude inputs are projected to increase from 16 to $18 \mathrm{Mbbl} / \mathrm{d}$ (with a steeper increase of 9\% from 2015 to 2021 and then a more gradual increase to 2050), gasoline output decreases 
from 8 to $6 \mathrm{Mbbl} / \mathrm{d}$, diesel output increases slightly, and average jet-fuel output increases roughly 0.5 $\mathrm{Mbbl} / \mathrm{d}$ from about 1.7 to $2.2 \mathrm{Mbbl} / \mathrm{d}^{11}$.

Future refinery hydrogen requirements are estimated based on linear regression of refineries characterized by Elgowainy and colleagues ${ }^{17}$ with crude American Petroleum Institute (API) gravity, crude sulfur content, gasoline-to-distillate ratio, and liquefied petroleum gas to total product ratio as the explanatory variables. The dataset includes 43 large refineries (each with capacity $>100,000 \mathrm{bbl} / \mathrm{d}$ ) in four Petroleum Administration for Defense District (PADD) regions covering over 70\% of U.S. refining capacity. Elgowainy and colleagues ${ }^{18}$ describe the details of the regression model and its valid range.

Refinery hydrogen demand by PADD region shown in Figure 9 is projected to increase due to increased ratio of diesel/gasoline demand, stringent sulfur requirements, higher API gravity and sulfur content for petroleum feedstocks, and increased petroleum inputs. This demand is estimated using the regression model and then allocated to individual refineries within each PADD based on the petroleum processing capacity of each refinery within the PADD.

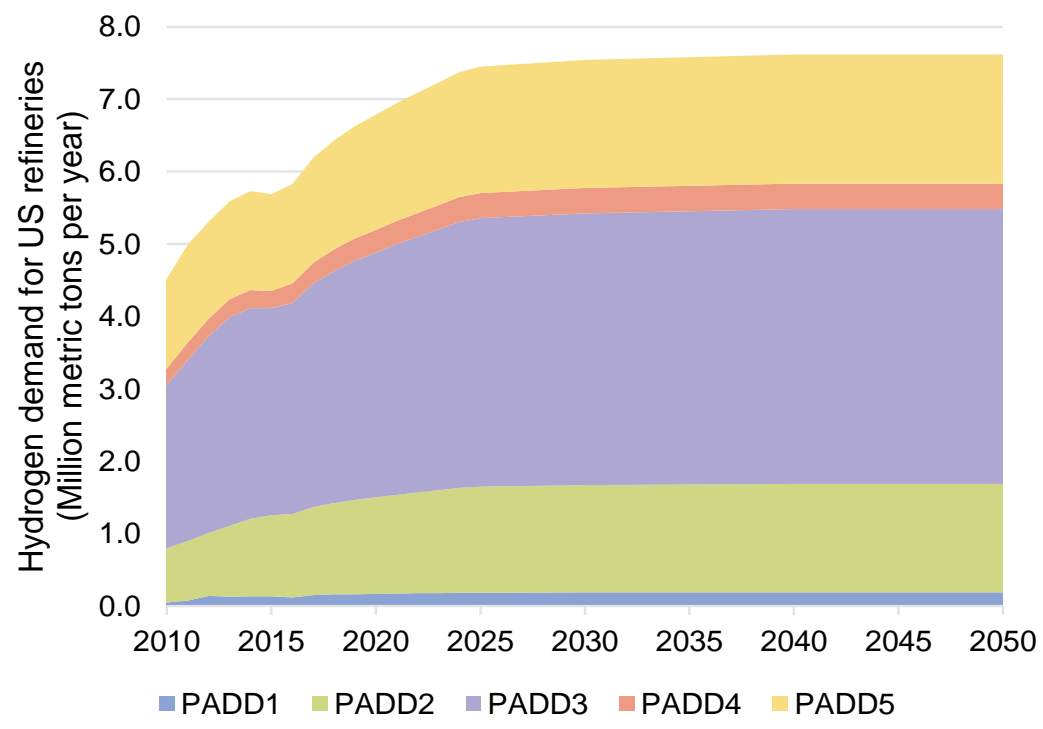

Figure 9. Projected total hydrogen demand for U.S. refineries by PADD, through 2050.

\subsubsection{Direct Reduced Iron for Metals Refining and Steel Production}

The direct reduction of iron is a process developed by Midrex Technologies, Inc. for producing high purity iron from ore at temperatures below the melting point of iron by reducing the iron oxide ore and driving off oxygen in a reactor using a reducing agent. The reducing agent can be elemental carbon from NG or coal, hydrogen or syngas. In the conventional approach to steel making, iron ore is reduced to pig iron using coking coal as the reducing agent in a blast furnace, and the pig iron is then converted to steel in a basic oxygen furnace (BOF). In the DRI process, DRI is converted to steel in an electric arc furnace (EAF), allowing reductions in overall energy use and $\mathrm{CO}_{2}$ emissions compared to the conventional steelproduction process. In the U.S., the amount of steel produced by EAF has been increasing and is expected to continue to grow, mainly due to the increased production of scrap, which can be incorporated in the EAF feed, while the amount produced by BOF is expected to remain relatively flat. Product quality dictates the amount of scrap that can be used in an EAF; the remainder must be made up with pig iron from a BOF or DRI. Due to its high purity, DRI has a potential to increase the amount of scrap which can be used by EAF relative to using pig iron from a BOF. The DRI process, using $100 \%$ hydrogen as the reducing agent, requires up to $100 \mathrm{~kg}$ hydrogen per metric tonne of steel-i.e., a mass ratio of approximately $10 \%$. However, using hydrogen in a blend with NG with up to 30/70 ratio by energy to 
produce DRI would not require modifications to the original, which was technology developed to work with only $\mathrm{NG}^{19}$.

Nuclear and renewable hydrogen could be used to offset NG or other fuels in the DRI process. For this analysis, we estimate the potential hydrogen demand for DRI based on using 30\% hydrogen and $70 \%$ NG on an energy basis ${ }^{19}$. The locations and scale of potential hydrogen use for DRI are estimated based on total steel-production capacity, national average utilization rates for BOFs and EAFs ${ }^{20}$, and national average DRI-feedstock shares. In 2015, BOFs and EAFs used 2.4 MMT and 1.7 MMT of DRI, respectively ${ }^{20}$. Thus, we estimate potential current hydrogen demand for current DRI to be $0.24 \mathrm{MMT} \mathrm{H}_{2}$ for BOF and $0.17 \mathrm{MMT}_{2}$ for EAF. The potential future demand for hydrogen use in the production of DRI assumes constant production by facility and replacing all pig-iron feed with DRI. In this case, hydrogen demand sees the greatest increase at the locations of current BOFs, where we estimate an additional $2 \mathrm{MMT}_{2}$ could be used for DRI (for a total of 2.2 MMT). EAFs experience more modest growth in hydrogen demand, mainly due to their large share of scrap inputs. The additional hydrogen demand for future DRI production at EAF locations is estimated to be $0.17 \mathrm{MMT}$ (for a total of $0.41 \mathrm{MMT}$ ). These estimates are conservative relative to the national estimate of Elgowainy et al. ${ }^{18}$ for potential future hydrogen demand of 4 MMT for $30 \%$ replacement of NG on an energy basis. Their estimates are based on the Annual Energy Outlook projection of 50\% growth in U.S. steel production by 2040 and full replacement of iron inputs with those produced by DRI. The GHG emissions associated with using DRI were assessed by comparing it with conventional blast furnace and EAF. These processes were evaluated using the GREET 2019 model for LCA, to estimate the eq. $\mathrm{CO}_{2}$ emissions for each process and highlight the benefits of using Nuclear- $\mathrm{H}_{2}$ in DRI production.

Figure 10 compares the eq. $\mathrm{CO}_{2}$ emissions per metric tonne (MT) of steel produced for four possible process steps in the steel making process: 1) Blast Furnace / BOF (using coal), 2) EAF (using grid electricity), 3) EAF (using nuclear electricity), and 4) DRI (using nuclear $\mathrm{H}_{2}$ ). The GHG emissions from each respectively is: 2.2-MT eq. $\mathrm{CO}_{2} / \mathrm{MT}$ steel from Blast Furnace, 0.91-ton eq. $\mathrm{CO}_{2} / \mathrm{MT}$ steel from EAF using grid electricity, 0.13-MT eq. $\mathrm{CO}_{2} / \mathrm{MT}$ steel from EAF using nuclear electricity, and 0.01-MT eq. $\mathrm{CO}_{2}$ / MT steel from DRI using Nuclear- $\mathrm{H}_{2}$, assuming the reducing agent is $100 \%$ hydrogen.

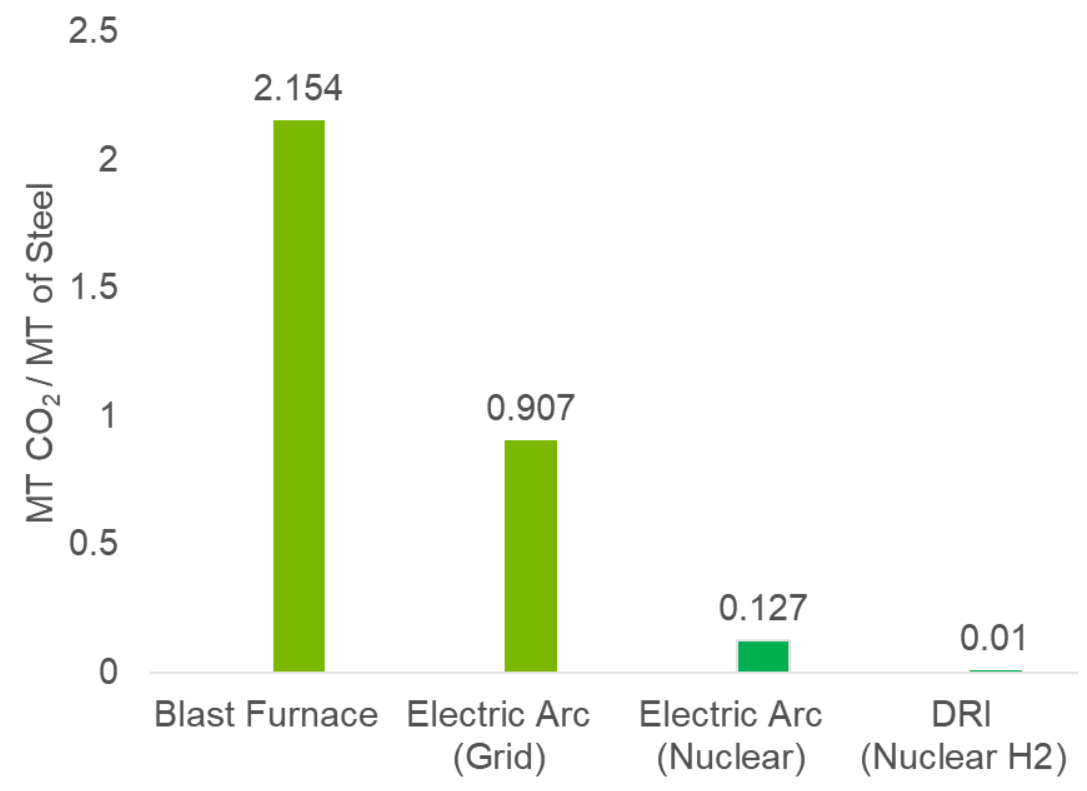

Figure 10. LCA of GHG emissions for various steel-making process options. 


\subsubsection{Ammonia and Fertilizers}

Ammonia is produced by the Haber-Bosch process, which reacts hydrogen, usually produced from NG via the SMR process, with nitrogen separated from the air. In 2016, 14 MMT of ammonia were consumed in the U.S. ${ }^{21}$, with $12 \%$ of consumption being for non-agricultural products, and the remainder used to produce fertilizer products, including anhydrous ammonia, urea, diammonium phosphate, monoammonium phosphate, and nitric acid. The Haber-Bosch process uses hydrogen in a molar ratio of 3 moles $\mathrm{H}_{2}$ to 2 moles of $\mathrm{NH}_{3}$; therefore, $0.178 \mathrm{~kg}$ of hydrogen are required to produce one $\mathrm{kg}$ of ammonia. As ammonia is the source of nitrogen in other fertilizer products, we can generalize this as $0.216 \mathrm{~kg}$ hydrogen per kilogram of nitrogen in fertilizer.

Estimated hydrogen demand locations for U.S. ammonia production in 2017, based on the ammonia production capacity, are shown in Figure 11. The locations and scale of ammonia production are estimated using plant capacities ${ }^{22}$ (Ammonia Industry 2018) and assuming the national average capacity utilization rate of $80 \%$. Future production by location through 2024 is estimated based on announced plans for capacity expansion by facility which include a 40\% expansion from 2019 to $2024^{22}$ (Ammonia Industry 2018). Currently $40 \%$ of the ammonia required for fertilizer products used in the U.S. is imported, so this expansion reflects the expectation that domestic production may potentially displace imports in the U.S. market due to the availability of low-cost green hydrogen. At the national level, Elgowainy and colleagues ${ }^{18}$ assumed that after 2024, U.S. ammonia production would increase through 2050 at a modest rate of $1 \%$ per year, assuming decreasing domestic demand for nitrogen fertilizer for corn, and relatively stable domestic demand for nitrogen fertilizer for other products, with the increased domestic production displacing nitrogen fertilizer imports in the U.S. market (Figure 12).

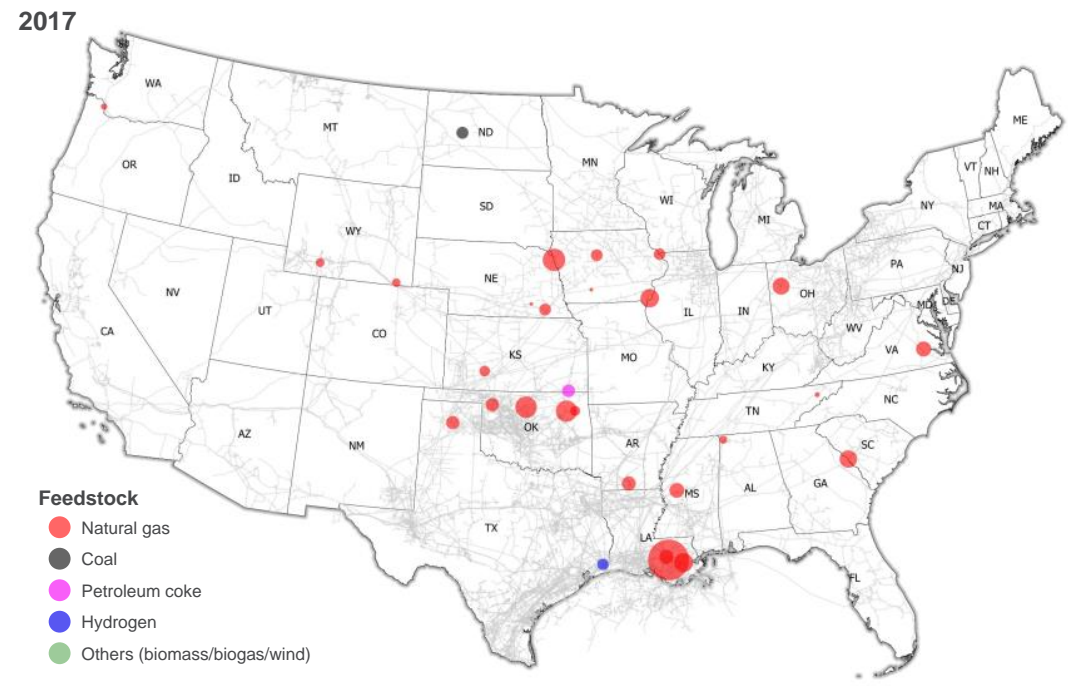

Figure 11. Estimated $\mathrm{H}_{2}$ Demand for U.S. $\mathrm{NH}_{3}$ Production in 2017. 


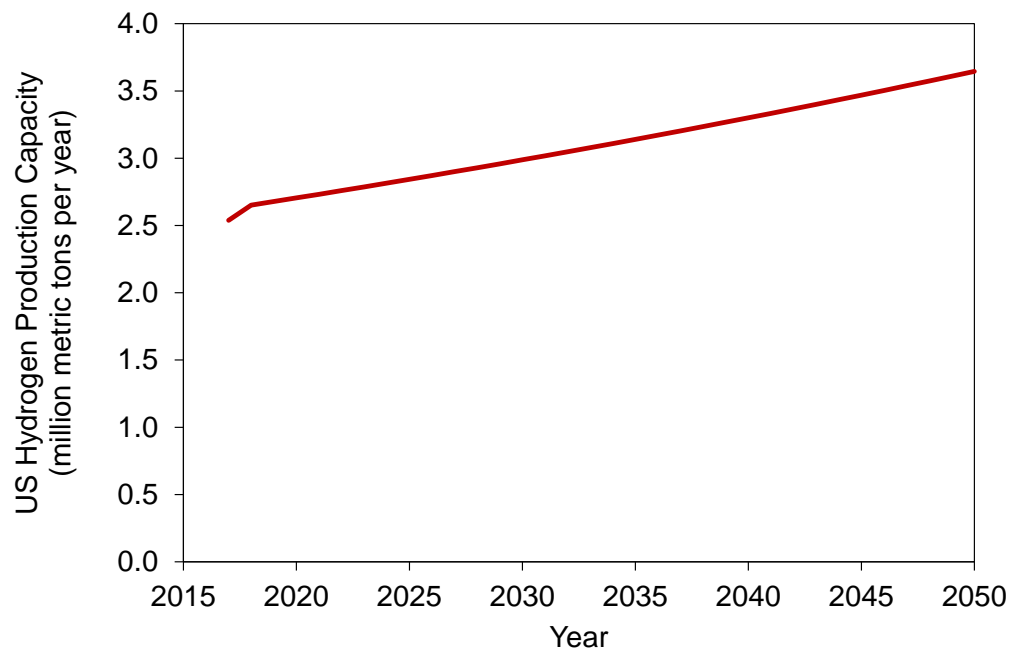

Figure 12. Current and projected hydrogen demand for U.S. $\mathrm{NH}_{3}$ production ${ }^{22}$ for the ammonia industry from 2018 through 2050, assuming an annual growth rate of 1\%).

To evaluate the environmental benefits and trade-offs for using nuclear- $\mathrm{H}_{2}$ for ammonia production, the Haber-Bosch process was considered. The GREET 2019 model was used to conduct the LCA for ammonia production. Various production pathways for hydrogen were considered to understand the eq $\mathrm{CO}_{2}$ emissions associated with various ammonia-feedstock sources and production pathways. Figure 13 compares $\mathrm{CO}_{2}$ emissions from the conventional ammonia-production process using nuclear- $\mathrm{H}_{2}$ or grid electricity for the air separation unit (ASU). The figure compares the eq $\mathrm{CO}_{2}$ per MT nitrogen in the fertilizer for three ammonia-production pathways, a baseline conventional pathway using SMR of $\mathrm{NG}$, another pathway using nuclear- $\mathrm{H}_{2}$ and grid electricity for the ASU, and a third pathway using nuclear power for both $\mathrm{H}_{2}$ production and the ASU. The conventional pathway produces about $2.9 \mathrm{MT} \mathrm{CO}_{2} /$ ton N while the nuclear- $\mathrm{H}_{2}$ and the nuclear for both $\mathrm{H}_{2}$ and ASU produce 1 and $0.01 \mathrm{MT} \mathrm{CO}_{2} /$ ton N, respectively, on a life-cycle basis.

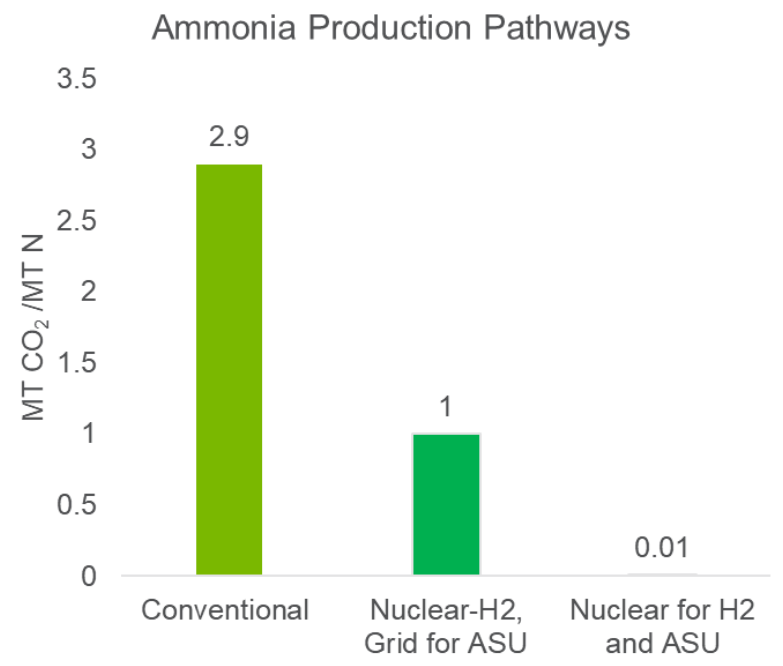

Figure 13. Life-cycle $\mathrm{CO}_{2}$ emission for ammonia-production pathways. 


\subsubsection{Oxygen}

\subsubsection{Overview of the current and near-future domestic oxygen market}

Assuming SOEC stacks that operate without an anode sweep gas, a $\sim 1$ GW NPP-associated waterelectrolysis plant could produce $\sim 5,500 \mathrm{MT} / \mathrm{d}$ of high-purity oxygen gas. $1 \mathrm{GW}$ is used as the rough average nuclear plant capacity. It is recognized that HTSE SOEC technology is not yet technically capable of producing hydrogen at the $1 \mathrm{GW}$ scale, but this number is used to show the hypothetical capacity once the technology of SOECs is able to reach this scale. U.S. industrial producers currently supply roughly $190,000 \mathrm{MT} / \mathrm{d}$ of enriched (85-99.9\% purity) oxygen, totaling more than $70 \mathrm{MMT}$ per year $^{23}$. These companies received an estimated $\$ 10$ B in revenue from oxygen sales in 2019, suggesting an average price of $\$ 0.13 / \mathrm{kg} \mathrm{O}_{2}$. This average estimate encompasses a wide range of price points, from $<\$ 0.10 / \mathrm{kg}$ for large-scale gaseous product from ASUs to $>\$ 1.00 / \mathrm{kg}$ for liquid or high-pressure $\mathrm{O}_{2}$ delivered in cylinders. The projected compound annual growth rate (CAGR) for the global industrial oxygen market is $6-7 \%{ }^{24}$. However, the mature nature of oxygen-consuming U.S. industries means that the projected domestic CAGR is a significantly lower: $1-3 \%$. At $2 \%$ growth, the U.S. will add an

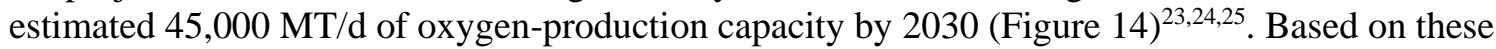
estimates, the total oxygen demand in 2030 could be supplied by 40-45 $1 \mathrm{GW}$ NPP-associated SOEC facilities performing water electrolysis. Given the long lifetime of legacy technologies like ASUs, it is unlikely that NPP facilities would satisfy $100 \%$ of either continuing or new demand. A single 1 GW NPPSOEC unit could produce more than 10\% of new demand projected for 2030.

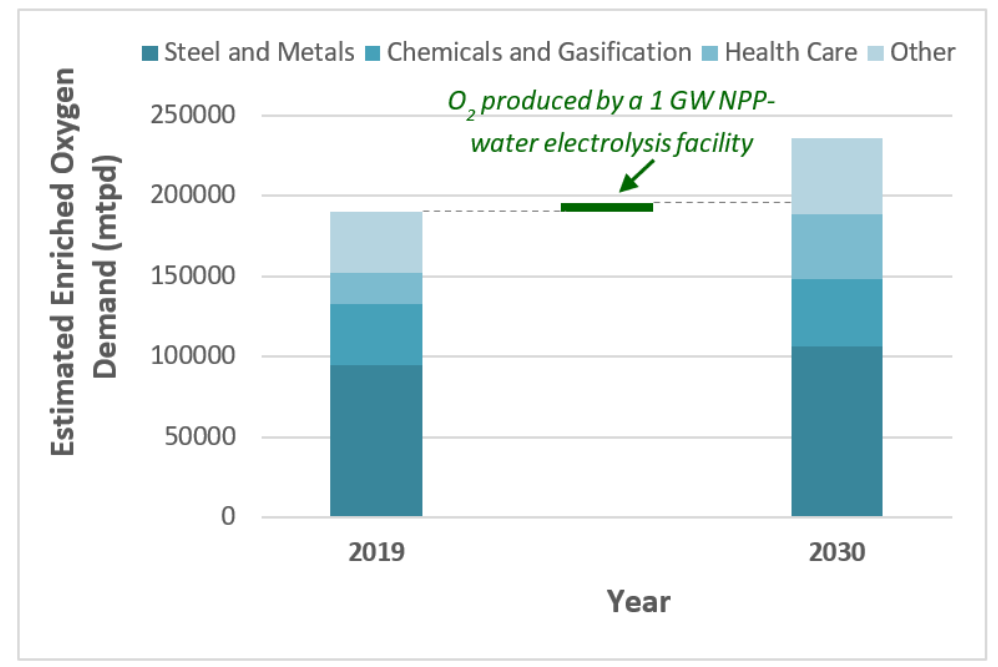

Figure 14. Estimated annual demand for enriched oxygen products by major consuming industry in 2019 and 2030, using current CAGR projections. The center bar shows the maximum daily $\mathrm{O}_{2}$ production of a 1 GW NPP-SOEC facility $(\sim 5,500 \mathrm{MT} / \mathrm{d})$.

Two technologies currently dominate industrial oxygen production: cryogenic air separation (CAS) and pressure-swing adsorption (PSA). The former generates $70-75 \%$ of all industrial oxygen and delivers $>99 \%$ pure $\mathrm{O}_{2}$ in both liquid and gaseous form. The gaseous-to-liquid $\mathrm{O}_{2}$ product ratio is about 4:126,27 . CAS units also produce pure nitrogen and argon for operations requiring inert-gas streams. PSA units generally operate at or near ambient temperature and produce a product of lower purity (85-95\%) than CAS technology. CAS units are typically built at large scale (100-5,000 MT/d) near point-source demand by large industrial gas companies ${ }^{28}$. By contrast, PSA units are simple and highly scalable, ranging from personal oxygen concentrators producing liters per day for breathing assistance to $\sim 50 \mathrm{MT} / \mathrm{d}$ units for industrial applications. PSA technology does not produce gases other than oxygen.

Industrial oxygen is used in a variety of industries, most notably: 
- Steel and Metals ( $50 \%$ of total demand)

- Chemical and gasification ( $20 \%$ of total demand)

- Health care $(\sim 10 \%$ of total demand)

- Other industries:

- Wastewater/solid waste treatment

- Glass and ceramics

- Paper and pulp

\section{Steel and Metals}

In 2019, the U.S. manufactured 87 MMT of steel, $70 \%$ from EAFs and 30\% from BOFs, requiring $\sim 35$ MMT of oxygen ${ }^{29}$. Total U.S. steel consumption is roughly 130 MMT, with the difference made up by imports, mainly from China, India, and Japan ${ }^{30}$. Recent projections of domestic growth have been below $1 \%$, but the near future is relatively uncertain because it is unclear how tariffs and new technologies will affect investment decisions ${ }^{31,32}$. During steel manufacturing, high-purity oxygen is injected directly into the molten metal to remove impurities, particularly carbon and silicon species. Excess nitrogen incorporation into steel causes the metal to become brittle; therefore, only high-purity oxygen can be used for this purpose. Oxygen is also used to enhance combustion, increasing flame temperatures for various steps of the steelmaking process. Both BOF and EAF technologies require substantial oxygen feeds, between $0.20-0.33 \mathrm{~kg} \mathrm{O}_{2}$ to produce kilogram of steel ${ }^{33}$. This range was used to estimate approximate oxygen-demand schedules for the steel mills discussed below. Oxygen is also used in other metals and manufacturing processes, most notably in oxy-fuel lances for cutting and processing. These applications represent small, distributed demand sources relative to the large point-source steel mills. The use of oxygen in this sector is directly tied to both overall steel demand and the economics of domestic production; therefore, tracking these factors will provide insight into future oxygen demand.

\section{Chemicals and Gasification}

In the chemicals industry, roughly $14 \mathrm{MMT} / \mathrm{year}$ of oxygen is used to synthesize oxidized chemical products and for combustion enhancement ${ }^{27}$. Many high-volume chemicals, notably ethylene oxide, propylene oxide, and phthalic acids, are produced using enriched-oxygen feeds to improve selectivity or reaction rates. Gasification of coal to produce syngas also requires large quantities of oxygen; 33 gasification facilities are currently operational in the $\mathrm{US}^{34}$. Gasification is a significant oxygen-demand source overseas, particularly in China. Increased demand for synfuels in the U.S., perhaps from recycled carbon sources, could increase oxygen demand in this sector. Refineries generating oxygen-containing products from oil or NG could likely be supplied by an adjacent ASU at low prices $(\leq \$ 0.05 / \mathrm{kg})$, making transportation costs key to evaluating the viability of centralized production near NPPs.

\section{Healthcare}

In health care, 7 MMT/year of enriched oxygen (85-95\%) is consumed, primarily as breathing assistance during both in- and outpatient care. Centralized demand sources such as large urban and suburban hospitals typically receive shipments of high-purity liquid oxygen from ASUs. This oxygen is then diluted to lower purities for applications such as surgery, anesthesia, medical instruments, and breathing aid ${ }^{35}$. Rural hospitals for whom liquid-oxygen shipments are not economic are increasingly installing on-site PSA units to provide cheap enriched $\mathrm{O}_{2}$. Distributed services such as breathing oxygen for outpatient care often use onsite PSA units. The health care sector is driving increases in oxygen demand overall, as domestic growth rates are projected to be $7 \%$ annually ${ }^{36}$. However, the distributed nature of this growth and the availability of cheap supply from small- and medium-scale PSA units (reducing transportation costs) may make the healthcare industry a poor fit for centralized NPP-SOEC units. 


\section{Other Industries}

Smaller-scale industrial uses of oxygen include wastewater treatment, glass and ceramics manufacture, and paper and pulp production ${ }^{23,24,25}$. In both the waste-management and paper industries, environmental concerns have led companies to replace toxic or caustic chemicals with oxygen feeds (occasionally enriched with ozone) ${ }^{27}$. These treatments remove contaminants or bleach products without potentially toxic waste streams. High-temperature combustion improves product quality in the glass and ceramics industries. Each of these applications is diffuse, and they lack point-source demands on the scale of steel mills or chemical refineries. Similar to hospitals, waste treatment or paper plants often receive shipments of liquid $\mathrm{O}_{2}$ via truck, although large facilities may have onsite generation capabilities installed $^{37}$. For these reasons, smaller-scale industrial uses of oxygen appear to be a poor fit for centralized NPP-HTSE plants.

\subsubsection{NPP-associated generation and the oxygen market}

While NPP-associated water electrolysis can produce inexpensive oxygen, centralized SOEC plants may have difficulty accessing key markets. The oxygen market is generally split into two categories: large point-source demand (e.g., steel mills and chemical plants) and distributed demand (e.g., healthcare and waste treatment) facilities. Large demand sources almost always have a dedicated oxygen-supply source such as a collocated $\mathrm{ASU}^{38}$. These large-scale units can provide cheap, high-purity gaseous $(\leq \$ 0.10 / \mathrm{kg})$ and liquid $(\leq \$ 0.15 / \mathrm{kg})$ oxygen with minimal transportation $\operatorname{costs}^{39,}{ }^{40}$. In distributed markets, oxygen is transported either as a liquid (taken directly from a cryo-distillation tower) or compressed gas. SOEC electrolysis stacks produce oxygen at high temperature and low pressure and would incur significant liquefaction or compression costs in preparation for distributed transportation. Locating a new demand source near an NPP is critical to reducing transportation costs, but oxygen cost is not often a determining factor in location choice. For steel mills and chemical plants, factors include feedstock costs (e.g., iron ore, recycled steel, naphtha, NG, etc.), proximity to markets, and labor costs. These play a larger role in location choice. The need for an oxygen supply will likely not be a determining factor in a firm's deciding whether to collocate a steel mill or chemical plant near an NPP, but when considered as a whole - with an abundant hydrogen and thermal energy supply that an NPP-HTSE hybrid plant could provide - the oxygen supply would be a convenient ancillary benefit.

In addition to difficulty of market access, the low price of commoditized oxygen suggests that $\mathrm{O}_{2}$ sales would have only a marginal effect on $\mathrm{H}_{2}$ price and, by extension, SOEC plant economics. A large point-source of oxygen demand might require $~ 700-1,000 \mathrm{MT} / \mathrm{d}$ of oxygen, or roughly a 1:1 mass ratio of $\mathrm{H}_{2}$ to $\mathrm{O}_{2}$ sales for a $1 \mathrm{GW}$ NPP, paired with a single large oxygen demand. Arranging oxygen demand to consume the full 5,500 MT/d oxygen generation from an NPP is considered unlikely. Analysis performed using the DOE hydrogen-analysis model indicates that selling $1-1.4 \mathrm{~kg}$ of oxygen for every kilogram of $\mathrm{H}_{2}$ at $\$ 0.10 / \mathrm{kg} \mathrm{O}_{2}$ (potentially a high price for the market) produces a revenue stream of $\$ 0.10-0.14 / \mathrm{kg}$ $\mathrm{H}_{2}$. While not negligible, these byproduct sales represent only a marginal decrease in the levelized cost of hydrogen production for SOEC plants and would likely not change the overall conclusions of an investment analysis. Thus, while oxygen sales would provide a boost to plant revenues, the difficulty of market access and low product price suggests that this revenue stream is not critical to overall plant economics and would likely be accessed only under the scenario of a large steel or chemical plant's being collocated with an NPP-HTSE hybrid plant.

\subsubsection{Co-Electrolysis-Carbon Dioxide Reduction with Water}

\subsubsection{Syngas}

As mentioned, the co-electrolysis process is under development. Co-electrolysis takes $\mathrm{CO}_{2}$ and water as feeds and produces $\mathrm{CO}, \mathrm{H}_{2}$, and $\mathrm{O}_{2}$. $\mathrm{CO}$ and $\mathrm{H}_{2}$, as a mixture, is called syngas because these two molecules can be used in a large number of processes synfuels and synthetic chemicals (synchems). The markets for syngas, synfuels and synchems are here discussed. 


\section{Synfuels and Synchemicals}

Significant quantities of high-purity $\mathrm{CO}_{2}$ are generated in industry processes such as ethanolproduction plants, SMR processes used for hydrogen production from NG for refining, ammonia production, NG power plants, and other purposes. These high-concentration $\mathrm{CO}_{2}$ sources present opportunities for the production of synchemicals and fuels such as methanol, Fischer-Tropsch (FT) diesel, and dimethyl ether (DME), while minimizing the cost and energy penalty to capture $\mathrm{CO}_{2}$ relative to other dilute $\mathrm{CO}_{2}$ sources (e.g., from flue gases of coal and $\mathrm{NG}$ power plants). Methanol production presents an opportunity because its manufacturing process is relatively simple, and its global market is expected to grow for multiple uses, such as petrochemicals, fuel blending, or as a blendstock for transportation-fuel production. Methanol produced from waste $\mathrm{CO}_{2}$ streams and hydrogen from clean nuclear energy offer a low-carbon alternative to methanol produced via the conventional process using NG. The merchant market for $\mathrm{CO}_{2}$ is currently underutilized. Of the $100 \mathrm{MMT}$ of $\mathrm{CO}_{2}$ generated from ethanol production and SMR, only 14 MMT are currently available to the merchant market, of which 11 MMT are used for food processing, carbonated beverages, and other uses ${ }^{41}$. This leaves a significant $\mathrm{CO}_{2}$ resource availability which could be used for methanol and synfuel production. In this report, we focus only on the potential hydrogen demand for synfuel production from highly concentrated sources of $\mathrm{CO}_{2}$. The potential hydrogen demand for methanol production from the same $\mathrm{CO}_{2}$ sources will be of a similar magnitude; thus, producing one chemical or fuel in lieu of the other will result in similar hydrogen demand considering the same $\mathrm{CO}_{2}$ resources.

The hydrogen demand for synfuel production can be estimated based on the stoichiometric 1:3 mole ratio of $\mathrm{CO}_{2}$ to $\mathrm{H}_{2}$ that is required for the synthesis of FT diesel or DME. The availability of high-purity $\mathrm{CO}_{2}$ from SMR associated with merchant hydrogen and ammonia production and the locations of facilities are based on values reported by facilities to the U.S. Environmental Protection Agency's Greenhouse Gas Reporting Program ${ }^{42}$. High-concentration $\mathrm{CO}_{2}$ sources from ethanol production is estimated based on the 1:1 mole ratio of ethanol to $\mathrm{CO}_{2}$ generated during the conversion of glucose and sucrose in the fermentation process. In 2017, 15.6 billion gal of ethanol were produced in the U.S. ${ }^{43}$, which generates an estimated $44 \mathrm{MMT}$ of high-purity $\mathrm{CO}_{2}$. The locations and capacities of ethanolproduction facilities are based on an EIA datase $t^{43}$ and illustrated in Figure 15, while production by facility is estimated based on the national average capacity-utilization rate. The total potential hydrogen demand to produce synfuels from high-purity, high-concentration $\mathrm{CO}_{2}$ sources is significant, at 14 MMT, comprised of 6.0 MMT of hydrogen for synthesis processes using ethanol plants' $\mathrm{CO}_{2}, 2.1 \mathrm{MMT}$ using $\mathrm{CO}_{2}$ associated with current ammonia production, and 5.9 MMT using $\mathrm{CO}_{2}$ associated with SMR for petroleum refining. While most ethanol production is clustered in Midwestern states, ammonia plants are located in a broader area, mainly in the Midwest, Gulf Coast, and Southeastern states, while other SMR plants are located near petroleum refineries, mostly along the Gulf Coast and near San Francisco, Los Angeles, Chicago, Detroit, Minneapolis, St. Louis, and Toledo. High-purity $\mathrm{CO}_{2}$ sources for syngas production are shown in the figures and tables in this report associated with ethanol plants (syngasethanol), SMR plants producing hydrogen (syngas- $\mathrm{H}_{2} \mathrm{SMR}$ ), and ammonia plants (syngas-ammonia). 


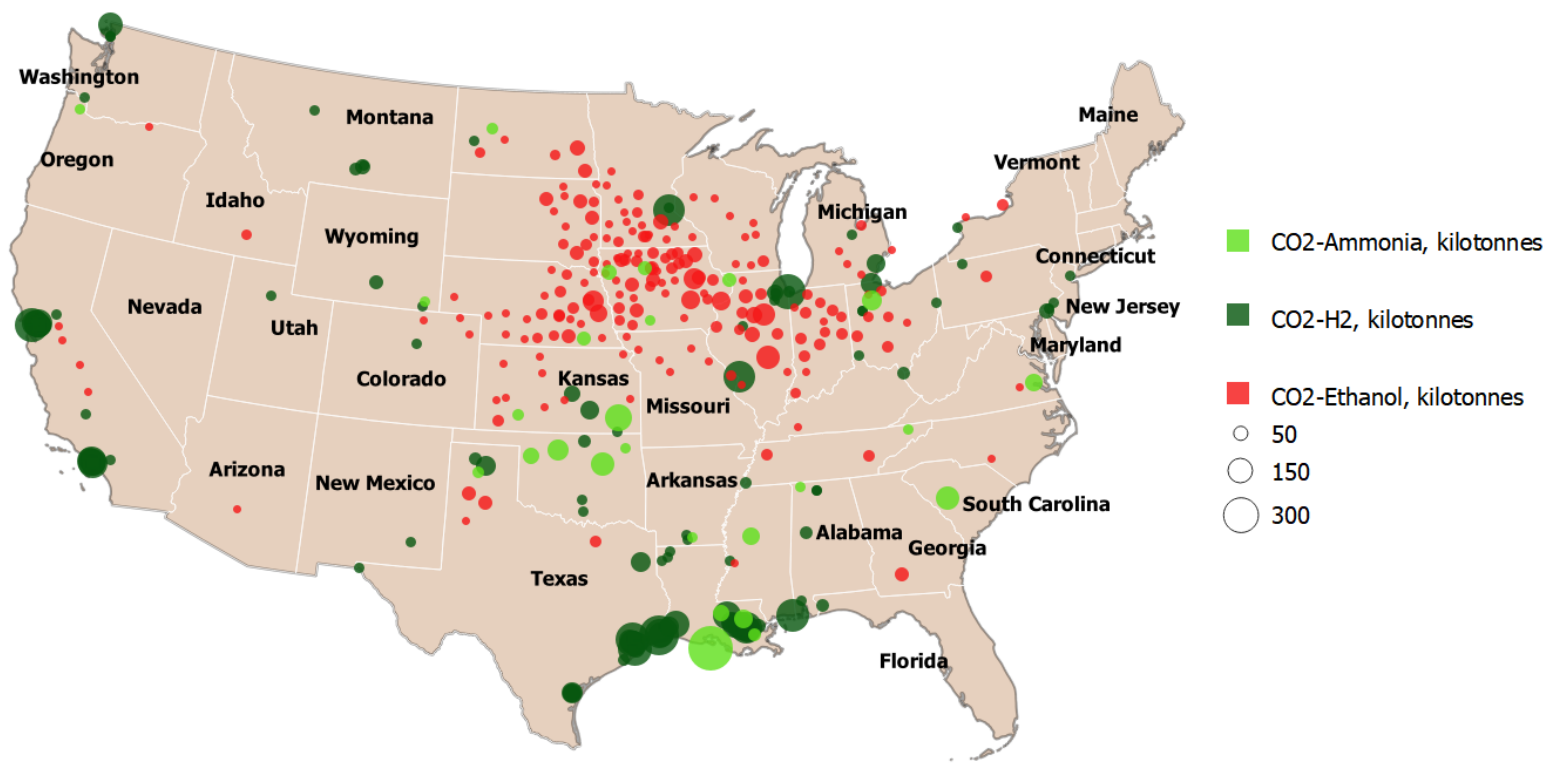

Figure $15 . \mathrm{CO}_{2}$ sources for use in synfuels production.

The life-cycle environmental benefits associated with synfuel production using low-carbon hydrogen from nuclear power, in terms of reduction of GHG emissions, were evaluated for the FT processes producing synfuel blends, such as FT naphtha and jet and diesel fuels. The GREET 2019 model was used to estimate GHG emissions assuming captured $\mathrm{CO}_{2}$ and nuclear- $\mathrm{H}_{2}$ for producing these synfuels. The GHG emissions associated with synfuel production and dispensing can be estimated using a WTW analysis. Figure 16 compares the GHG emission for the production of conventional fuels, such as gasoline and jet and diesel fuels, to highlight the benefits of the FT pathway using nuclear $\mathrm{H}_{2}$. The carbon dioxide equivalent emissions per megajoule of gasoline, jet fuel, diesel fuel, and FT fuel pathways are about 94, 86, 93 and $6 \mathrm{~g} \mathrm{CO}_{2}$ eq./MJ respectively.

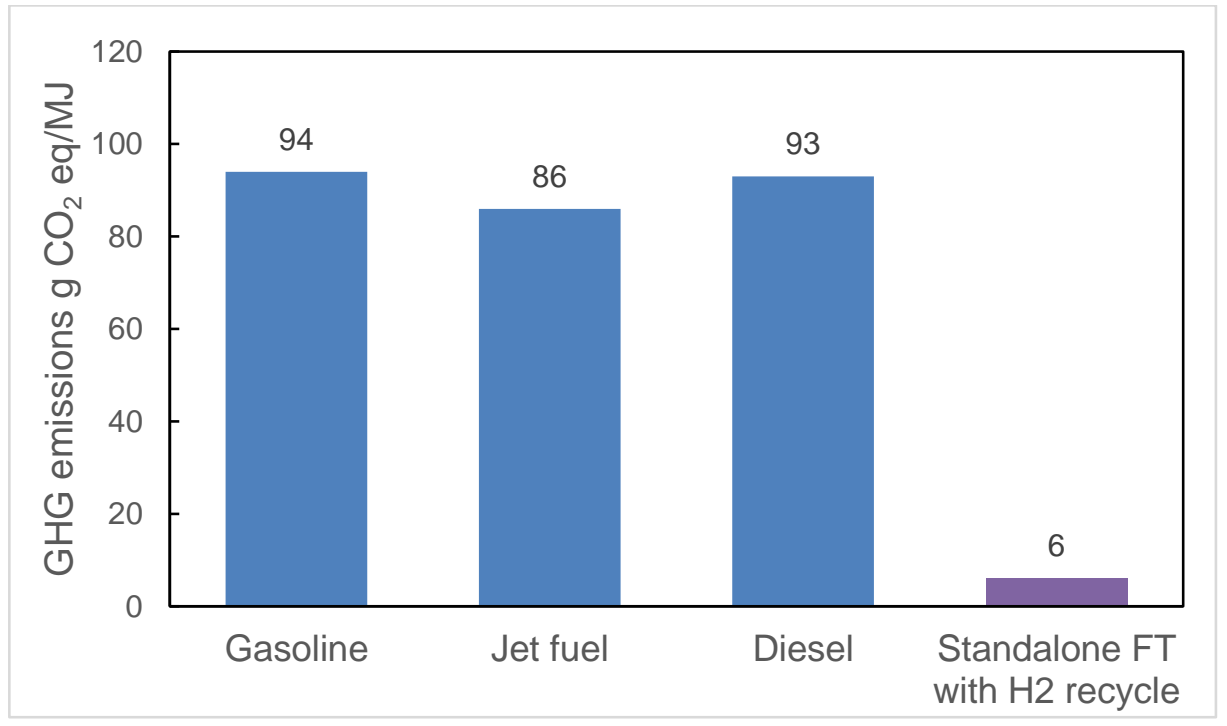

Figure 16. WTW total- $\mathrm{O}_{2}$ emissions for gasoline, jet fuel, diesel and FT fuel (produced using nuclear $\mathrm{H}_{2}$ ). 


\section{Syngas for Metals Refining}

Hydrogen use in metals refining has been discussed above. Syngas $\left(\mathrm{CO}+\mathrm{H}_{2}\right)$ generated from an adjusted SMR process using NG is what is currently used in the metals industry. Syngas can alternatively be produced and supplied to metals plants using $\mathrm{CO}_{2}$ and water in the co-electrolysis process as described. There are a few advantages to using a carbon-containing molecule such as $\mathrm{CO}$ in addition to hydrogen in the metals refining process. First, different grades of steel require varied amounts of carbon as part of the finished alloy in order to obtain the desired material properties, so carbon will need to be incorporated regardless. Second, some carbon can be consumed in the metals-refining process, releasing energy and resulting in a more-economic process overall due to the reduced outside-heating requirements versus a metals-refining process using only hydrogen as the reducing agent.

\subsubsection{Formic acid}

FA can be produced economically using an electrochemical process by baseload low-carbon NPPs using $\mathrm{CO}_{2}$ from sources such as local ethanol plants and even SMR plants. This has the potential to be game changing for the chemical industry. FA could serve as a durable liquid (at ambient conditions), and energy-dense hydrogen carrier that could be produced by electrolysis (co-electrolysis of $\mathrm{CO}_{2}$ and water to make FA $)^{44,45}$.

\section{Overview of the Current and Near-Future Formic Acid Market}

FA is defined as a high-volume chemical, with global production totaling 1.2 MMT per year ${ }^{46}$. The total market value is estimated to be $\$ 1.1 \mathrm{~B}$, indicating a global benchmark price of $\$ 1.00 / \mathrm{kg}$; U.S. prices are $\sim 25 \%$ higher $^{47,48,49}$. U.S. demand is currently relatively small, around $0.125 \mathrm{MMT} /$ year or $\sim 10 \%$ of the global demand, $40 \%$ (i.e., $0.05 \mathrm{MMT} / \mathrm{y}$ ) of which is produced in a single facility in Geismar, Louisiana, operated by BASF ${ }^{50}$. The remaining $60 \%$ of demand is supplied by imports from China and Germany. Worldwide growth is strong - estimated at nearly 5\% CAGR through 2027-and domesticgrowth estimates are even more optimistic, ranging from 5-14\% CAGR due to emerging applications for $\mathrm{FA}^{51}$. Drivers for growth are

1. Current commodity chemical use switching from a U.S. import to a U.S. export

2. Use as a silage preservation to reduce need for animal antibiotics

3. Fracking/drilling-completion fluids

4. Displacement of phosphoric acid for cleaning and descaling applications ${ }^{52}$

5. Breaking down and hydrogenating carbonaceous (biomass) feedstock into high-value chemicals and fuels

6. Use of a liquid-hydrogen carrier that is easily stored and transported to distributed users.

At this growth rate, the global market will grow to $2 \mathrm{MMT} /$ year of capacity by 2030 .

Conventional processes produce FA via carbonylation of methanol or carbonylation of oxalic acid. Electrochemical catalytic co-electrolysis of $\mathrm{CO}_{2}$ and water to make $\mathrm{FA}$ is a promising emerging process, and one manufacturer, OCO Chemicals, boasts of a $78 \%$ efficient process with high selectivity (99\%) with their licensed process that reduces $\mathrm{CO}_{2}$ with in situ-generated hydrogen from water to $\mathrm{FA}$ or formate salts $^{53}$.

Currently, FA is used to make natural and synthetic leathers, textiles, cleaning products, rubber, and formate salts are used as deicing agents and additives in oil and gas drilling fluids ${ }^{54}$. Abroad, the major use of FA (accounting for $40 \%$ of demand) is as an antimicrobial additive in animal feed, but this practice is uncommon in the U.S. due to "generally low commercial availability of formic acid $55,56,57$." Domestic farmers use antibiotics instead, a practice which has come under scrutiny, presenting an opportunity for increased FA production and use ${ }^{58}$. FA is chemically stable and relatively nontoxic (at concentrations 
below 90\%), making it an attractive chemical product for farming applications. The FDA has denoted FA as "generally recognized as safe," and the European Union (EU) has certified it as a permissible additive for both human and animal food ${ }^{59,60}$. The Midwest (particularly Iowa, Minnesota, and Wisconsin) contains clusters of industrial cattle and pig farms, while the Southeast is a center for chicken farming ${ }^{61}$. NPPs in these regions making liquid products such as FA would have straightforward access to these markets. FA replacement of antibiotics in animal feed, whether motivated by regulation, public scrutiny, or price, would lead to a significant increase in domestic FA demand.

Other possibilities for replacing current chemicals, specifically acetic acid (AA), are also promising, although on a smaller scale than animal feed. Roughly $15 \mathrm{MMT} /$ year of AA are manufactured worldwide, most commonly used to produce VA monomers, food-grade vinegar, acetic anhydride (an industrial solvent), and acetate salts. FA cannot replace AA as a monomer or in vinegar, but BASF markets FA as a replacement for AA (and acetate salts) in deicing agents and solvents, indicating the possibility of expanded FA demand ${ }^{62}$. In particular, potassium salt deicing agents represent a growth area, as potassium formate has already replaced potassium acetate for deicing at European and North American airports ${ }^{58}$.

In addition to its use by traditional industries, FA also holds substantial promise as a hydrogen carrier for direct or indirect use in fuel-cell technologies. FA is both energy dense $(1,760 \mathrm{Wh} / \mathrm{kg})$ and hydrogendense $(53 \mathrm{~g} / \mathrm{L}, 44 \mathrm{~g} / \mathrm{kg}$ ), containing more hydrogen per volume than compressed hydrogen itself (at moderate pressures ${ }^{53,54}$. It is a liquid at ambient temperature, stable, nontoxic, and durable enough for long-term storage. Further, hydrogen release from FA is exergonic ( $<0$ free-energy change) but not exothermic ( $>0$ enthalpy change). This allows hydrogen release to be performed at low temperatures but, perhaps more importantly, at high pressures that may be suitable for storage in fuel-cell vehicles. Other hydrogen carriers (e.g., ammonia and methanol) do not have this property, and it has been estimated to reduce storage, compression, and dispensing costs of a hydrogen refueling station by $60-70 \%{ }^{63}$. These properties have led to increased interest in FA as a potential hydrogen carrier ${ }^{64,65}$. Growth of this market, combined with technological advances in co-electrolysis, could see FA become a major industrial chemical in the long-term future.

\section{Analysis of Nuclear Power Plant Facilities and the Formic Acid Market}

With substantial growth in the market, co-electrolysis to generate FA could play a revenue-generating role in a multipurpose NPP-associated facility. A single 1 GW NPP using currently available lowefficiency co-electrolysis technology could produce more than the present global demand for FA each year. INL has previously estimated the required energy input for electrolytic FA synthesis at $\sim 4 \mathrm{MWh} / 1000 \mathrm{~kg}$, assuming a large overpotential (>2 V) to increase cell current densities ${ }^{65}$. One gigawatt of constant electricity input could therefore produce the current annual demand of FA (1.2 MMT) in $\sim 5000 \mathrm{~h}$, or around 7 months. Assuming an electricity price of $\$ 25-40 / \mathrm{MWh}$, the energy input costs are $\$ 0.10-0.22 / \mathrm{kg}$ FA. Assuming amortized capital expenditures of $\$ 0.20-0.25 / \mathrm{kg}$ (estimate from OCO, Inc.) the cost of electrochemical FA production is $\sim \$ 0.30-0.47 / \mathrm{kg}$. These cost targets would make FA cheaper than many alternative chemicals, opening up new markets such as silage preservation, cleaning agents, and chemicals processing. To achieve these goals, research and development is needed to increase the efficiency and current density of co-electrolysis cells, which will reduce both the operating and capital costs. If cell efficiencies are increased and the market grows significantly, particularly through adoption of FA as an $\mathrm{H}_{2}$-energy carrier, FA production would be very well suited for NPP facility integration, especially when configured as a component of the energy industrial park concept discussed above.

\subsubsection{Summary of Electrolysis Markets}

\subsubsection{Estimates of competitive hydrogen cost for various markets and applications}

The estimates of threshold price in Figure 2 depicts the price at which the application would utilize hydrogen in lieu of an alternative feedstock, assuming no available incentives for low-carbon hydrogen and no penalties for carbon-generating feedstocks. 
Table 1. Estimated threshold price for hydrogen to replace alternate feedstocks, by application.

\begin{tabular}{|c|c|c|}
\hline Application & $\begin{array}{c}\text { Threshold Hydrogen } \\
\text { Production Price }\end{array}$ & Notes \\
\hline LD FCEVs & $\$ 2-3 / \mathrm{kg}$ & DOE targets for FCEVs \\
\hline $\begin{array}{l}\text { Medium- and HD } \\
\text { FCEVs }\end{array}$ & $\$ 2-3 / \mathrm{kg}$ & DOE targets for FCEVs \\
\hline Petroleum Refining & Up to $\$ 3 / \mathrm{kg}$ & $\begin{array}{l}\text { Competitive with SMR. No substitute } \\
\text { for hydrogen in refining process } \\
\text { (inelastic demand) }\end{array}$ \\
\hline $\mathrm{NH}_{3}$ & $\$ 2 / \mathrm{kg}$ & $\begin{array}{l}\text { Price to be competitive with imported } \\
\text { ammonia }\end{array}$ \\
\hline Synthetic FT Diesel & $\$ 1-1.5 / \mathrm{kg}$ & Price to compete with petroleum diesel \\
\hline $\begin{array}{l}\text { Injection to NG } \\
\text { Infrastructure }\end{array}$ & $\$ 0.8-1 / \mathrm{kg}$ & $\begin{array}{l}\text { Price to compete with NG on thermal- } \\
\text { energy content, based on higher } \\
\text { heating value }\end{array}$ \\
\hline $\begin{array}{l}\text { Iron Reduction and } \\
\text { Steelmaking }\end{array}$ & $\$ 0.8-1 / \mathrm{kg}$ & $\begin{array}{l}\text { Price for hydrogen to compete with } \\
\text { NG in DRI }\end{array}$ \\
\hline
\end{tabular}

\subsubsection{Hydrogen storage and infrastructure cost}

As stated earlier, hydrogen can be produced using LWRs at NPPs during low-demand periods when the selling price of electricity is less than the marginal cost of operation, to assist in sustainable NPP operation. The produced $\mathrm{H}_{2}$ from these NPPs can be used in various industries as described in the previous section. Hydrogen produced at the NPP site can be transported to the demand locations via a dedicated delivery infrastructure, including storage, packaging, and transportation components. Alternatively, the nuclear power can be transmitted to the demand location, where hydrogen can be produced and used, although the added cost of transmitting and/or distributing the electric power and the inability to integrate NPP thermal energy to the electrolysis process would impact the efficiency and operation cost of producing the hydrogen. The scale of demand and its distance from the NPP would determine the economics and, thus, the mode of delivery of hydrogen from the NPP to the demand locations. Hydrogen markets tend to have inelastic hydrogen demand. Thus, the hydrogen-production plant must be able to provide hydrogen to its markets regardless of electricity pricing. In order to fully monetize both the electricity and the hydrogen markets, hydrogen-storage capabilities are needed to mitigate any mismatch between hydrogen supply and demand. Hydrogen storage provides the nuclear facility with the flexibility to operate fully in the grid-electricity and hydrogen markets. Hydrogen can be stored at low pressures (of 150 to 500 bar) economically with a cost between $\$ 600-1000$ per kilogram of hydrogen for a high-pressure vessel storage system, depending on the storage pressure, type of vessel (Types I-IV), and the nature of pressure cycles. The storage system should also include a system that compresses the hydrogen into the storage system. The capital cost of the storage and compressor for such a system are shown in Table 2. Hydrogen also may be liquefied and stored in cryogenic vessels. The cost of hydrogen liquefaction and storage are also shown in Table 2. The information in Table 2 are extracted from ANL's Hydrogen Delivery Scenario Analysis Model. ${ }^{66}$

The gaseous hydrogen produced at an NPP can be transported to the demand location via pipelines for large-scale demand (tens to hundreds of tonnes per day), and tube-trailers for small-scale demand locations (e.g., fueling stations with capacities of up to $1 \mathrm{MT} / \mathrm{d}$ ). Compressors improve the density of hydrogen before transportation via a tube-trailer or pipeline. In general, transporting the hydrogen at higher densities enables more-economical transportation. Table 3 shows the capital cost of pipelines, 
tube-trailers, and cryogenic tankers for transporting gaseous and liquid hydrogen, based on the ANL model.

Table 2. Cost of hydrogen storage options.

\begin{tabular}{|l|l|}
\hline \multicolumn{2}{|c|}{ STORAGE OPTIONS FOR HYDROGEN } \\
\hline LOW-PRESSURE STORAGE & Vessel Capacity $\times \$ 600-1000 / \mathrm{Kg} \_\mathrm{H} 2$ \\
\hline Storage Cost & $40,500 \times$ Motor Power $(\mathrm{In} \mathrm{Kw})^{0.46}$ \\
\hline Compressor Cost & $3,738,563 \times\left(\right.$ Cavern Capacity $\left.\left.(\mathrm{In} \mathrm{M})^{3}\right) / 19000000\right)^{0.7}$ \\
\hline Geologic Storage & Density @ 2000 psi And 20oc Is $10.5 \mathrm{Kg} / \mathrm{M}^{3}$ \\
\hline Cavern Cost & $6893 \times(\text { Motor Power In Kw })^{\wedge} 0.7464$ \\
\hline \multicolumn{2}{|c|}{} \\
\hline Compressor Cost & $6,350,000 \times(\text { Liquefaction Capacity In Tonne/Day })^{0.8}$ \\
\hline LIQUID-HYDROGEN STORAGE & $5,646,600+3100 \times$ Storage Volume In $\left(\mathrm{M}^{3}\right)$ \\
\hline Liquefaction Cost & $5,646,600+3100 \times$ Storage Volume In $\left(\mathrm{M}^{3}\right)$ \\
\hline Cryogenic Storage Cost &
\end{tabular}

Table 3. Transportation cost of hydrogen using various delivery options.

\begin{tabular}{|c|c|}
\hline \multicolumn{2}{|r|}{ DELIVERY OPTIONS FOR HYDROGEN } \\
\hline PIPELINE COST & \\
\hline Material Cost & $69330 \times \operatorname{Exp}($ Diameter $[$ In Inches] $\times 0.0697) \times($ Length, Miles $)$ \\
\hline Labor Cost & $\begin{array}{l}\text { [56.5323 } \times \text { Diameter }(\text { In Inches })^{2}+47875.3 \times \text { Diameter }(\text { In Inches }) \\
+17788.1] \times \text { Length }(\text { In Miles })\end{array}$ \\
\hline Right-Of-Way Cost & $\begin{array}{l}{[-9 \mathrm{e}-13 \times \text { Diameter }(\text { In Inches }) 2+4,417.1 \times \text { Diameter }(\text { In Inches })+} \\
164,241] \times \text { Length }(\text { In Miles) }\end{array}$ \\
\hline Miscellaneous Cost & $\begin{array}{l}{\left[333.443 \times \text { Diameter }(\text { In Inches })^{2}+14198.8 \times \text { Diameter }(\text { In Inches })\right.} \\
+135569.5] \times \text { Length }(\text { In Miles })\end{array}$ \\
\hline Compressor Cost & $40,500 \times$ Motor Power $(\mathrm{In} \mathrm{Kw})^{\wedge} 0.46$ \\
\hline Tube-Trailer & $1100 \$ / \mathrm{Kg} \_\mathrm{H} 2$ (Tubes And Trailer) + Tractor Cost $(\$ 70,000)$ \\
\hline Cryogenic Liquid Tanker & $1,000,000+$ Tractor Cost $(\$ 100,000)$ \\
\hline
\end{tabular}

\subsection{Electrochemical Monomer Production - Ethylene}

An early technology readiness level (TRL) electrochemical process is being developed at INL that converts ethane (a component of NG) into ethylene and hydrogen ${ }^{67}$. Alternatively, an analogous process 
could be used to produce propylene or other higher-carbon-chain olefin monomers. This process is termed electrochemical non-oxidative deprotonation (ENDP). The ENDP process could be a future candidate for integration and coupling with an NPP providing electrical and thermal energy to the process. Currently, the ENDP process has been demonstrated at bench scale. Preliminary technoeconomic analysis and process modeling of a hypothetical scale increase of the ENDP process has been performed ${ }^{68}$. Possible markets to employ the hydrogen that could be produced via the ENDP process have been discussed. This section will focus on the potential markets for ethylene and propylene that could be potentially tapped by the NPP-ENDP process.

\subsubsection{Overview of Ethylene and Associated Polymer Markets}

Ethylene is the second-most produced chemical in the world (after ammonia), totaling over 185 MMT globally in $2019^{69}$. In 2018, the U.S. produced approximately 30 MMT of ethylene, and significant domestic capacity additions suggest that the domestic share of the global market will increase in the near future $^{70,71}$.

Ethylene is typically converted into key-commodity monomers, proceeding to polymer and plastic products. The most notable end-product polymers using ethylene as a key input material are

- Polyethylene: Roughly 100 MMT/year global demand in 2019, divided into a variety of high-volume products including ${ }^{72}$ :

- High-density polyethylene (HDPE)

- $\quad$ Low-density polyethylene (LDPE)

- $\quad$ Linear low-density polyethylene (LLDPE)

- Others (ultrahigh-molecular weight polyethylene and cross-linked polyethylene)

- Vinyl chloride: $47 \mathrm{MMT} / \mathrm{year}$ in $2019^{73}$

- Ethylene oxide: 26 MMT/year in $2019^{74}$

Ethylene is rarely an end product, and the vast majority of ethylene is converted into other intermediates or monomers for commercial and industrial polymers. Some examples of ethylene upgrading in the polymer supply chain include:

- Chlorine addition to yield ethylene dichloride, which is further converted into vinyl chloride (VC). $\mathrm{VC}$ is polymerized to polyvinyl chloride (PVC) for use in piping, plastic parts, insulation, etc.

- Reaction with benzene to yield ethyl benzene, which is dehydrogenated to make styrene. Styrene is polymerized to polystyrene, used for plastic cutlery and packaging (e.g., Styrofoam), as well as rigid plastics.

- Reaction with acetic acid to yield VA. VA is polymerized to polyvinyl acetate, used in food packaging and glues.

- Oxidation to yield ethylene oxide, which is hydrolyzed to make ethylene glycol (EG). EG is used directly as a lubricant and antifreeze, or copolymerized with terephthalate to make polyethylene terephthalates, used in plastic bottles, jugs, and other packaging.

These examples represent just a fraction of the wide diversity of ethylene-containing products that are commonly used in packaging (including plastic wraps and films), bottles and jugs, piping, plastic parts, toys, textiles, lubricants, and surfactants. Ethylene-derived polymers are generally desirable due to their versatility, ease of processing, and low cost. Due to sustained demand and new polymerization technologies that improve resin performance and yield, ethylene market experts project sustained compound annual growth rates of $\sim 4 \%$ through 2030, at or above global gross domestic product growth in this period ${ }^{75,76,77,78}$. Although the applications are quite diverse, the ethylene and polyethylene markets are mature and highly commoditized with stiff price competition. As a caution on market-growth projections, 
common applications of ethylene-derived products, such as single-use plastics, have become subject to environmental scrutiny and bans.

Nearly $80 \%$ of global ethylene is synthesized via catalytic steam cracking of either petroleum-derived naphtha $(\sim 40 \%)$ or ethane separated from NG $(\sim 38 \%)^{76}$. The majority of U.S. ethylene cracker plants are located in Texas and Louisiana, although Shell is constructing a major polyethelene facility in Western Pennsylvania ${ }^{79,80,81}$. Economies of scale are critical to profitable production of ethylene derivatives, particularly polyethelene. Plants are typically integrated facilities that produce ethylene from naphtha and/or ethane, and upgrade the olefin into downstream derivative products such as polyethelene (in various grades), ethylene oxide, or VC. Feedstock prices account for the the majority of costs in these high-volume commodity chemicals. Low NG prices in the U.S. have provided a competitive advantage for domestic chemical producers, leading to large investments in ethylene and polyethylene facilities in recent years ${ }^{75,76,77}$. Nearly 11 MMT of capacity has been or is projected to be added in the U.S. between 2017 and $2024^{74}$. These investments are typically made by multinational petrochemical companies such as Dow Chemical, ChevronPhillips, LyondellBasell, ExxonMobil, and SABIC.

Prices for ethylene derivatives, for example polyethylene, are heavily commoditized and volatile as a result of global supply and demand dynamics (Figure 17). Polyethylene is produced in a variety of grade, or densities, with the most widely used HDPE accounting for nearly half of total demand in 2018. Prices for the various polyethylene grades are generally similar, and currently fall between $\$ 0.60-0.90 / \mathrm{kg}$ wholesale $^{82}$. Average polyethylene prices are forecast to rise at or below inflation (1.5-1.7\%) through $2022^{72}$. As shown in Figure 17, the various types of polyethylene are subject to the same supply and demand forces, and therefore prices tend to rise and fall simultaneously with only minor differences over time.

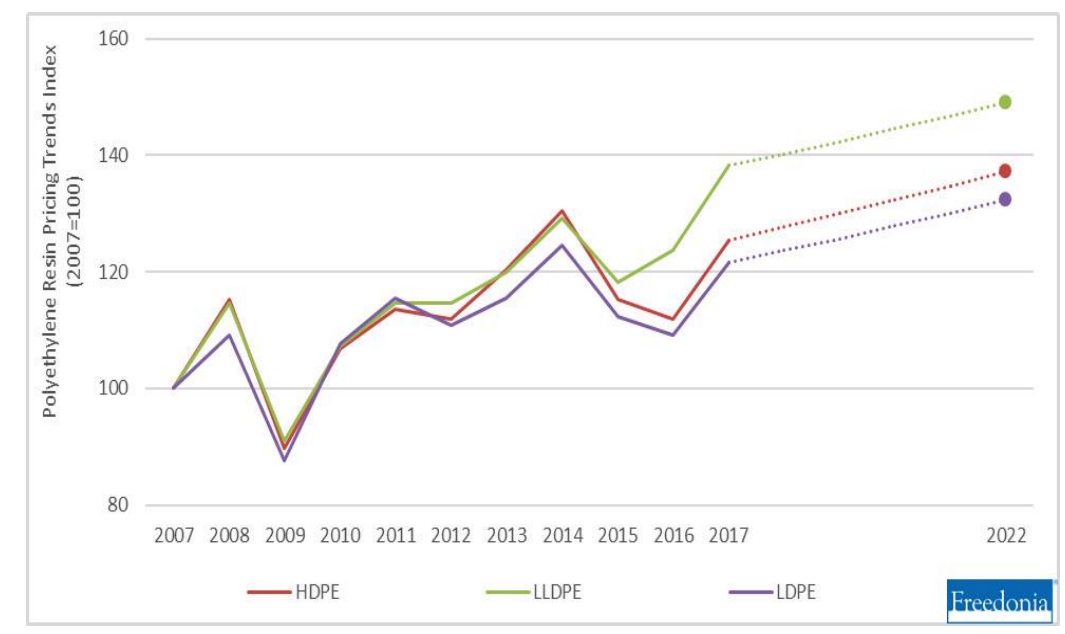

Figure 17. U.S. polyethylene prices by index, 2007-2022 $(2007=100)^{72}$.

Although the production of ethylene, commodity chemical derivatives, and polymers in pellet or crumb form is centralized on the Gulf Coast, manufacturing of plastic commercial and industrial end products from these building-block commodity chemicals is highly distributed. There are an estimated 16,000 plastics-production sites within the U.S., representing a wide range of firms from local companies to multinational conglomerates ${ }^{83}$. Many of these plastics-manufacturing firms are concentrated near the NPPs discussed in this study, including in the Midwest (Wisconsin, Illinois, Indiana, Michigan, and Ohio), Northeast (Pennsylvania, New York, and New Jersey) and Southeast (North Carolina, South Carolina, Georgia, and Alabama) ${ }^{84}$. Currently, commodity chemicals such as polyethylene or PVC are produced on the Gulf Coast and shipped in pellet or crumb form to demand sources upwards of 1,000 miles away. Polyethylene and PVC are solids at ambient conditions, making transportation technically straightforward, but industry analysts have identified logistics as a major sales bottleneck for chemicals 
producers. Logistical inefficiencies, including rail delays, labor availability, and deep-water port access, are estimated to translate to more than $\$ 50 \mathrm{~B}$ in excess inventory and operating costs for suppliers over the next decade. The concentration of chemical manufacturers on the Gulf Coast is a major contributor to these logistical challenges. Locating new chemical manufacturing near supply concentrations in the Midwest, Northeast, and Southeast, as well as eastern seaboard ports, could side-step many issues and provide new plants with a competitive advantage in transportation costs ${ }^{85}$.

The under-construction Royal Dutch Shell plant is seeking to exploit the combination of low NG price and relative proximity to polymer demand with a 1.6 MMT/year polyethylene plant currently under construction in Monaca, Pennsylvania, costing an estimated $\$ 6 \mathrm{~B}^{81}$. This location is near the Marcellus and Utica NG deposits and will be within 700 miles of $73 \%$ of U.S. and Canada polyethylene demand (Figure 18). Therefore, an NPP-ENDP coupled-commodity plastics plant located in this region could achieve competitive advantages on both feedstock NG and product transportation costs. In addition to domestic demand, the facility is reasonably close to current export terminals such as Marcus Hook, Pennsylvania, near Philadelphia ${ }^{86}$.

The Royal Dutch Shell plant could serve as a surrogate proof-of-concept for NPP-associated ethylene production facilities with similar transportation-cost advantages. The gas deposits are near multiple Midwest and Mid-Atlantic NPPs and Monaco, Pennsylvania, itself is near the Beaver Valley LWR. Thus, the region presents the synergies of 1) geographic overlap of low NG prices, 2) high regional concentration of nuclear energy, and 3) high regional demand for polymers.

Finally, the national or local regulatory and tax environment can play a large role in enticing investment. The Pennsylvania Shell plant has reportedly received tax breaks that could amount to $\$ 1.6 \mathrm{~B}$ over the next decade ${ }^{81}$.

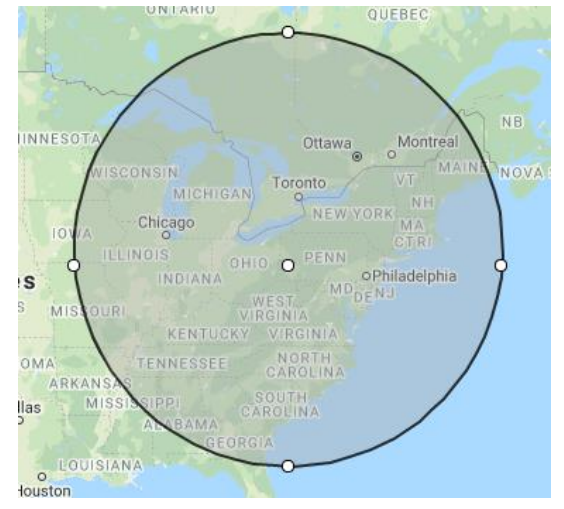

Figure 18. Seventy-three percent of U.S. and Canada polyethylene demand is within 700 miles of the new Shell plant in Monaca, Pennsylvania, at the center of the above circle.[13] This region covers includes the majority of INL partner NPP facilities.

\subsubsection{Analysis of NPP-associated facilities and the Ethylene Market}

Through 2030, commoditized ethylene and derivatives production will be determined by global structural factors, but NPPs may have cost advantages that make them well-suited to produce these chemicals. Ethylene productivity growth and pricing tends to closely track global gross domestic product growth and oil and gas prices, respectively. However, proximity to the Marcellus, Devonian, and Utica shale deposits suggests that NPPs in the Midwest and Mid-Atlantic may be able to access a low-cost ethane (or propane) feedstock. Further, the concentration of polymer demand sources (such as plastics manufacturers) in the Midwest and Northeast suggests that well-located chemical suppliers could undercut Gulf Coast manufacturers on transportation costs. In addition, plants located near the Great Lakes or East Coast could sell into the substantial export markets, which are projected to grow due to low ethane-feedstock prices in the U.S. Thus, ENDP plants powered by NPPs in Illinois, Ohio, Minnesota, 
Pennsylvania, and New York could have a number of economic factors in their favor, provided the technology platform is reasonably competitive with current thermochemical-production methods.

Ethylene and ethylene-derivative products could be considered as key components of an industrial energy park model centered on NPP facilities. ENDP is a relatively low-energy process, requiring $<1 \mathrm{~V}$ input at modest temperatures $\left(\sim 400^{\circ} \mathrm{C}\right)^{67}$. At these conditions, a $1 \mathrm{GW}$ NPP could produce around $15,500 \mathrm{MT} / \mathrm{d}$ of ethylene, or roughly 4.5 MMT/year (assuming 300 days of operation per year). For comparison, the large Shell plant under construction in Pennsylvania is estimated to have 1.6 MMT/year of capacity. Given this scale, it is reasonable to consider a multiproduct industrial energy park model where NPP electricity is supplied to a variety of electrolysis units working in concert to produce a broad range of monomer, polymer, and plastic products in addition to hydrogen. For example, the following technologies could all be operated simultaneously:

- Water electrolysis, producing hydrogen and oxygen

- Ethane electrolysis, producing ethylene and hydrogen

- Brine electrolysis, producing chlorine

- Co-electrolysis of water and carbon dioxide, producing syngas, formates, and possibly acetates.

In addition to direct hydrogen sales, this group of products can be combined to synthesize the key monomers and polymers outlined above, including:

- Direct polymerization of ethylene to polyethylene

- Ethylene chlorination to VC

- Ethylene oxidation to ethylene oxide, and further hydration to EG

- Combination of ethylene and acetic acid to synthesize VA

These monomers can then be upgraded onsite to polymer products, mirroring the vertically integrated production methods used in chemical refineries today. A $1 \mathrm{GW}$ NPP is capable of generating enough electricity to manufacture large (i.e., approaching $1 \mathrm{MMT} / \mathrm{year}$ ) quantities of each product, realizing economies of scale in a variety of chemical markets. This strategy distributes investment and operational risk across a variety of products and allows each NPP to identify local market opportunities when determining the scale of each technology installation. ENDP could also be applied to propylene production, opening another set of massive chemical markets ( 110 MMT in 2019) ${ }^{87,88}$. Substantial advances in proton-conducting electrolysis cell (PCEC) technology are required before implementation, but the field is active with research and development. Overall, an industrial energy park centered around an NPP facility is an attractive concept that seems to offer high efficiency and good economics in a largescale project of national economic importance. 


\section{REGION-SPECIFIC DEMAND}

Various regions around the country were selected for study of the regional nonelectric industrial product markets that might be accessed near NPPs. Regions selected include the Illinois, Minnesota, Ohio, Alabama and Georgia, Arizona, North / South Carolina, New York, and more broad midnortheastern regions (e.g., see Figure 19).

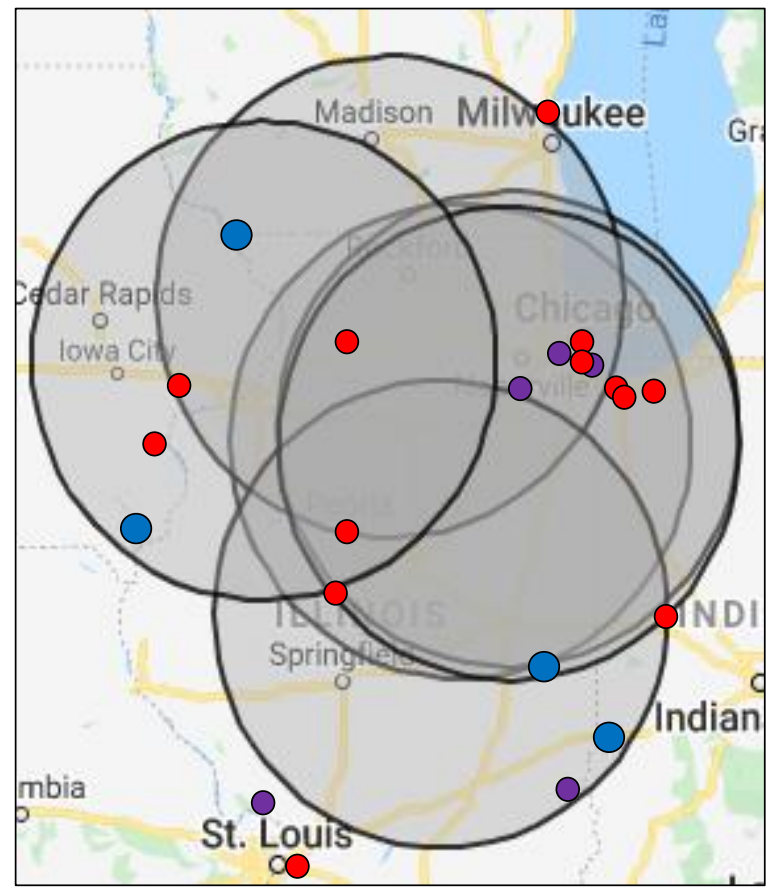

Figure 19. Location of ammonia plants (blue), oil refineries (purple), and steel mills (red) within 100 miles of the NPP facilities in Illinois. Large filled circles are drawn to indicate a 100-mile radius around each NPP

\subsection{Illinois Region}

This region includes six NPPs (Dresden, Braidwood, LaSalle, Clinton, Quad Cities, and Byron) with a total generating capacity of $11.6 \mathrm{GW}^{89}$. There are many large-demand point sources in the region, including:

- Four ammonia plants, totaling $~ 1,000 \mathrm{MT} /$ day $\mathrm{H}_{2}$

- Expanding the region to within 300 miles of NPPs captures six additional ammonia plants requiring 2,000 additional metric tonnes per day of hydrogen ${ }^{90}$

- Five oil refineries, totaling $300 \mathrm{MT} / \mathrm{day} \mathrm{H}_{2}$ (in addition to a small quantity of oxygen) ${ }^{91}$

- $\quad$ Thirteen steel mills, totaling $\sim 19,000 \mathrm{MT} /$ day $\mathrm{O}_{2}{ }^{92}$

Although only four ammonia plants fall within a 100-mile radius, 10 ammonia plants exist within a 300 -mile radius of the Illinois plants generally, totaling $~ 3,000 \mathrm{MT} /$ day of $\mathrm{H}_{2}$ demand $^{90}$. In addition, the Chicago area remains an industrial hub for the Midwest, with five oil refineries and some of the largest steel plants in the country ${ }^{91,92,93}$. Similar to ammonia plants, if the relevant radius were extended to 200 miles, an additional 5,000 MT/day of oxygen demand from steel plants in Michigan, southern Illinois, and Missouri could be accessed ${ }^{92}$. Growth in large point-source demand is difficult to project, but in general, the oil-refining and steel industries exhibit slow projected growth rates $(<2 \%)$ that make opening a new facility or expanding capacity of existing facilities in this region challenging ${ }^{30,94}$. 
In the electricity markets, Illinois is split between the PJM RTO (Quad Cities, Byron, Dresden, Braidwood, and LaSalle NPPs) and the Mid-continent ISO (Clinton) regions. As noted above, the 3-year forward-capacity market auction for PJM is currently suspended awaiting new rules from FERC regarding intermittent renewable energy sources. Illinois has also enacted state subsidies that have run afoul of new FERC rules, and Illinois state leadership has suggested that leaving the PJM market may be required to achieve renewable-energy targets ${ }^{95}$. Draft legislation promoting carbon-free or carbon-neutral energy generation proposes to set up a new capacity market that would be favorable to the nuclear facilities in the Illinois region, but as of February 2020, the future is unclear ${ }^{9}$. Previous capacity-market prices in PJM have varied from roughly \$75/MW-day to more than \$160/MW-day (see discussion above). The Clinton NPP facility is located in the Mid-continent ISO, but not the Minnesota region; therefore, capacity payments are quite low, only \$2.99/MW-day in the winter of 2019-20204.

High purity $\mathrm{CO}_{2}$ sources for syngas production are shown in the figures and tables in this report associated with ethanol plants (syngas-ethanol), SMR plants producing hydrogen (syngas- $\mathrm{H}_{2} \mathrm{SMR}$ ), and ammonia plants (syngas-ammonia). The demand for each location has been studied and listed for each location with maps and tables. The label "NG Electricity Generators" signifies potential hydrogen demand calculated for an NG power plant assuming they use a mixture of $30 \% \mathrm{H}_{2}$ in NG. The label "Syngas-Ethanol", "Syngas-H2 SMR" and "Syngas-Ammonia" refer to high purity $\mathrm{CO}_{2}$ sources for syngas production. The labels "Refinery" and "Ammonia" signify demand for hydrogen at the specific refinery location or ammonia-production plant. The label "FCEVs" demand is the hydrogen demand estimated for the hydrogen-fueled FCEVs at the county level. The label "DRI" is the demand of hydrogen estimated for direct reduction of iron at metal-refining facilities at the locations marked on the maps.

\subsubsection{Clinton NPP, Bloomington, IL}

Near-term potential hydrogen demand near the Clinton facility depends mainly on the potential of cocombusting hydrogen with NG in electricity generators, while a few DRI opportunities exist, which adds to this demand. The near-term cumulative potential hydrogen demand for this location is approximately $44 \mathrm{MT} /$ day. Eighteen NG electricity generators within 100 miles of the Clinton facility have a combined potential hydrogen demand of $41 \mathrm{MT} /$ day if hydrogen is blended with NG in a 30/70 volume ratio. Most of this demand is associated with four facilities which make up more than half of that demand; these are the Holland Energy Facility, the Tuscola Station, the University of Illinois Abbott Power Plant, and the Archer Daniels Midland Peoria plant.

Potential future hydrogen demand near the Clinton location will be most likely for synfuel production and for co-combustion of hydrogen with NG. Potential synfuel producing facilities within 100 miles of the Clinton plant could be co-located with ethanol plants, producing FT fuels as the major product. The combined potential demand for FT fuel production is about 1300 MT/day, about half of which is associated with two Illinois facilities, Archer Daniels Midland in Decatur and Marquis Energy in Hennepin, at 400 and 350 MT/day, respectively. Fertilizer producer Cronus Chemical in Tuscola is associated with a hydrogen demand of about $400 \mathrm{MT} /$ day and is only 60 miles from the Clinton facility. A few DRI opportunities near the Clinton location will require another 14 MT/day of hydrogen by 2030. FCEVs add less than $1 \mathrm{MT}$ /day to this demand because the use of hydrogen by FCEVs is limited by their low market penetration and the region's low population density. The cumulative future potential demand around the Clinton power plant is estimated at $1800 \mathrm{MT} / \mathrm{day}$. A list of identified sources of hydrogen demand near the Clinton plant is found in Table 4. Current and future demand are illustrated in Figure 20 and Figure 21. 


\begin{tabular}{|c|c|c|c|c|}
\hline \multirow[b]{2}{*}{ Name } & \multirow[b]{2}{*}{ Demand Type } & \multicolumn{2}{|c|}{$\begin{array}{c}\text { Potential } \mathrm{H}_{2} \text { Demand, } \\
\text { kilotonnes }\end{array}$} & \multirow[b]{2}{*}{$\begin{array}{l}\text { Distance, } \\
\text { miles }\end{array}$} \\
\hline & & $\begin{array}{l}\text { Current } \\
(2017)\end{array}$ & $\begin{array}{l}\text { Future } \\
(2030)\end{array}$ & \\
\hline De Witt County, IL & FCEV & - & 0.00 & 5.50 \\
\hline Goose Creek Energy Center: Union Electric Co - (MO) & NG Electricity Generators & 0.21 & 0.21 & 17.50 \\
\hline Piatt County, IL & FCEV & - & 0.00 & 24.30 \\
\hline McLean County, IL & FCEV & - & 0.00 & 29.10 \\
\hline Macon County, IL & FCEV & - & 0.00 & 30.10 \\
\hline Archer Daniels Midland Decatur: Archer Daniels Midland Co & NG Electricity Generators & 0.04 & 0.04 & 30.90 \\
\hline Logan County, IL & FCEV & - & 0.00 & 31.10 \\
\hline Adm Decatur Il, Decatur & Syngas: Ethanol & - & 150.00 & 31.50 \\
\hline One Earth Energy LLC, Gibson City & Syngas: Ethanol & - & 40.00 & 34.20 \\
\hline Gibson City Energy Center LLC: Mainline Generation LLC & NG Electricity Generators & 0.45 & 0.45 & 34.50 \\
\hline Champaign County, IL & FCEV & - & 0.00 & 36.70 \\
\hline University of Illinois Abbott Power Plt: University of Illinois & NG Electricity Generators & 2.26 & 2.26 & 38.00 \\
\hline Ford County, IL & FCEV & - & 0.00 & 45.10 \\
\hline Moultrie County, IL & FCEV & - & 0.00 & 47.60 \\
\hline Interstate: City of Springfield - (IL) & NG Electricity Generators & 0.18 & 0.18 & 50.90 \\
\hline Dallman: City of Springfield - (IL) & NG Electricity Generators & 0.12 & 0.12 & 55.80 \\
\hline Sangamon County, IL & FCEV & - & 0.00 & 57.20 \\
\hline Cronus Chemical, Tuscola & Ammonia & - & 147.00 & 57.30 \\
\hline Douglas County, IL & FCEV & - & 0.00 & 58.90 \\
\hline Tuscola Station: DTE Tuscola, LLC & NG Electricity Generators & 2.64 & 2.64 & 59.20 \\
\hline Woodford County, IL & FCEV & - & 0.00 & 59.80 \\
\hline Menard County, IL & FCEV & - & 0.00 & 60.30 \\
\hline Christian County, IL & FCEV & - & 0.00 & 62.00 \\
\hline Tazewell County, IL & FCEV & - & 0.00 & 64.50 \\
\hline Livingston County, IL & FCEV & - & 0.00 & 65.80 \\
\hline
\end{tabular}




\begin{tabular}{|c|c|c|c|c|}
\hline Shelby County, IL & FCEV & - & 0.00 & 67.90 \\
\hline Tilton: Tilton Energy LLC & NG Electricity Generators & 0.73 & 0.73 & 68.10 \\
\hline Mason County, IL & FCEV & - & 0.00 & 68.40 \\
\hline Adm Peoria Il, Peoria & Syngas: Ethanol & - & 70.00 & 68.80 \\
\hline Archer Daniels Midland Peoria: Archer Daniels Midland Co & NG Electricity Generators & 2.19 & 2.19 & 68.80 \\
\hline Keystone Steel and Wire Co. & DRI & 0.88 & 3.10 & 70.40 \\
\hline Powerton: Midwest Generations EME LLC & NG Electricity Generators & 0.04 & 0.04 & 70.60 \\
\hline Vermilion County, IL & FCEV & - & 0.00 & 70.70 \\
\hline Pacific Ethanol Pekin Inc, Pekin & Syngas: Ethanol & - & 60.00 & 71.00 \\
\hline Illinois Corn Processing LLC, Pekin & Syngas: Ethanol & - & 30.00 & 71.20 \\
\hline Kincaid Generation LLC: Dynegy Kincaid Generation & NG Electricity Generators & 0.04 & 0.04 & 71.30 \\
\hline Peoria County, IL & FCEV & - & 0.00 & 72.50 \\
\hline Iroquois County, IL & FCEV & - & 0.00 & 73.20 \\
\hline Evonik Corporation & Syngas: Hydrogen, SMR & - & 1.76 & 78.30 \\
\hline Coles County, IL & FCEV & - & 0.00 & 80.60 \\
\hline Marshall County, IL & FCEV & - & 0.00 & 84.40 \\
\hline Marquis Energy LLC, Hennepin & Syngas: Ethanol & - & 130.00 & 87.20 \\
\hline Montgomery County, IL & FCEV & - & 0.00 & 89.40 \\
\hline Morgan County, IL & FCEV & - & 0.00 & 90.00 \\
\hline Holland Energy Facility: NAES Corporation - (WA) & NG Electricity Generators & 4.06 & 4.06 & 90.90 \\
\hline Fountain County, IN & FCEV & - & 0.00 & 91.10 \\
\hline Cass County, IL & FCEV & - & 0.00 & 92.20 \\
\hline Vermillion Energy Facility: Duke Energy Ohio Inc & NG Electricity Generators & 0.61 & 0.61 & 92.80 \\
\hline Putnam County, IL & FCEV & - & 0.00 & 94.20 \\
\hline Kankakee County, IL & FCEV & - & 0.00 & 95.10 \\
\hline Cayuga: Duke Energy Indiana, LLC & NG Electricity Generators & 0.00 & 0.00 & 95.50 \\
\hline Energy Shelby County: Shelby County Energy Center, LLC & NG Electricity Generators & 0.85 & 0.85 & 95.80 \\
\hline Warren County, IN & FCEV & - & 0.00 & 96.20 \\
\hline Edgar County, IL & FCEV & - & 0.00 & 96.80 \\
\hline
\end{tabular}




\begin{tabular}{|c|c|c|c|c|}
\hline Bunge Oil: CSL Behring LLC & NG Electricity Generators & 0.18 & 0.18 & 97.10 \\
\hline CSL Behring LLC: CSL Behring LLC & NG Electricity Generators & 0.21 & 0.21 & 97.20 \\
\hline Nucor Steel - Kankakee Inc. & DRI & 0.56 & 1.99 & 98.50 \\
\hline Benton County, IN & FCEV & - & 0.00 & 98.90 \\
\hline Freedom Power Project: Southwestern Electric Coop Inc - (IL) & NG Electricity Generators & 0.02 & 0.02 & 98.90 \\
\hline Cumberland County, IL & FCEV & - & 0.00 & 99.20 \\
\hline Grundy County, IL & FCEV & - & 0.00 & 100.00 \\
\hline
\end{tabular}




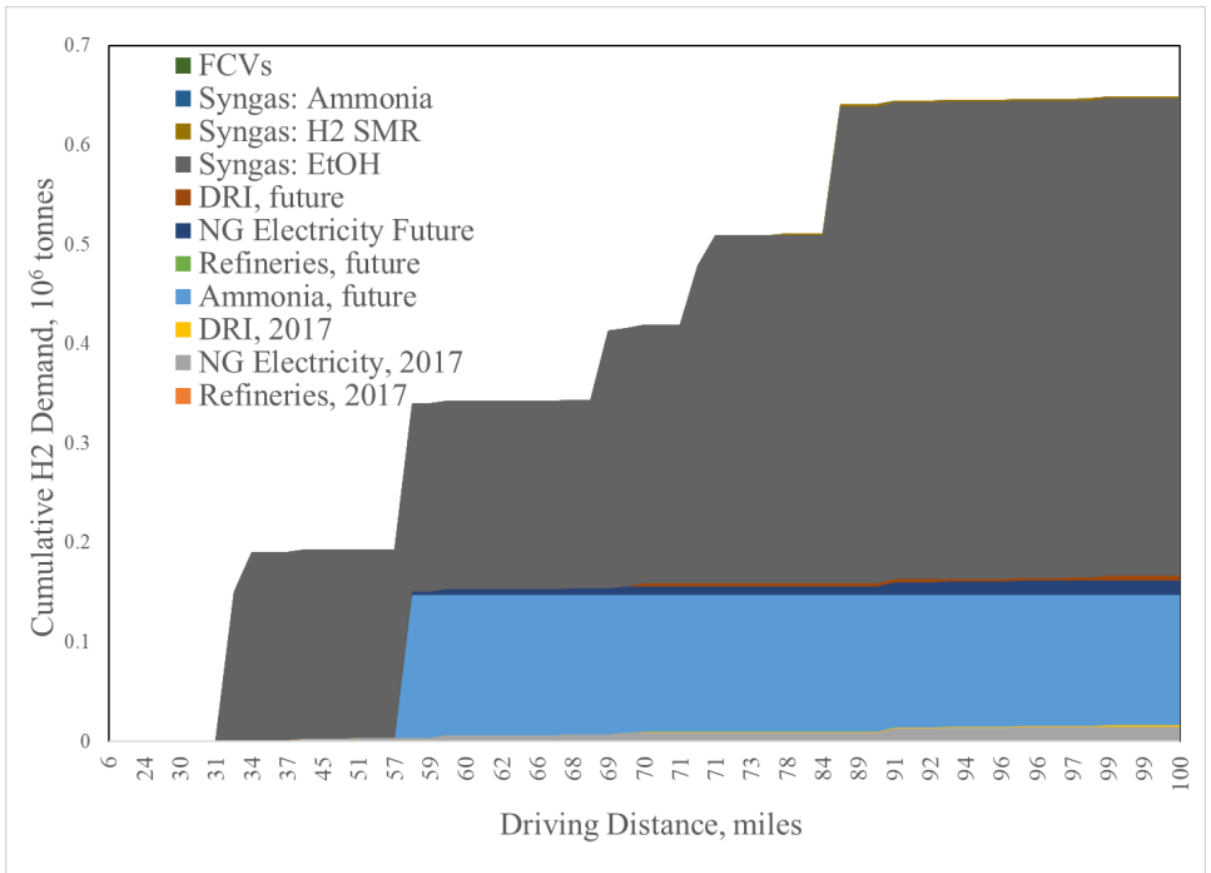

Figure 20. Cumulative potential hydrogen demand by type and distance near the Clinton power plant.

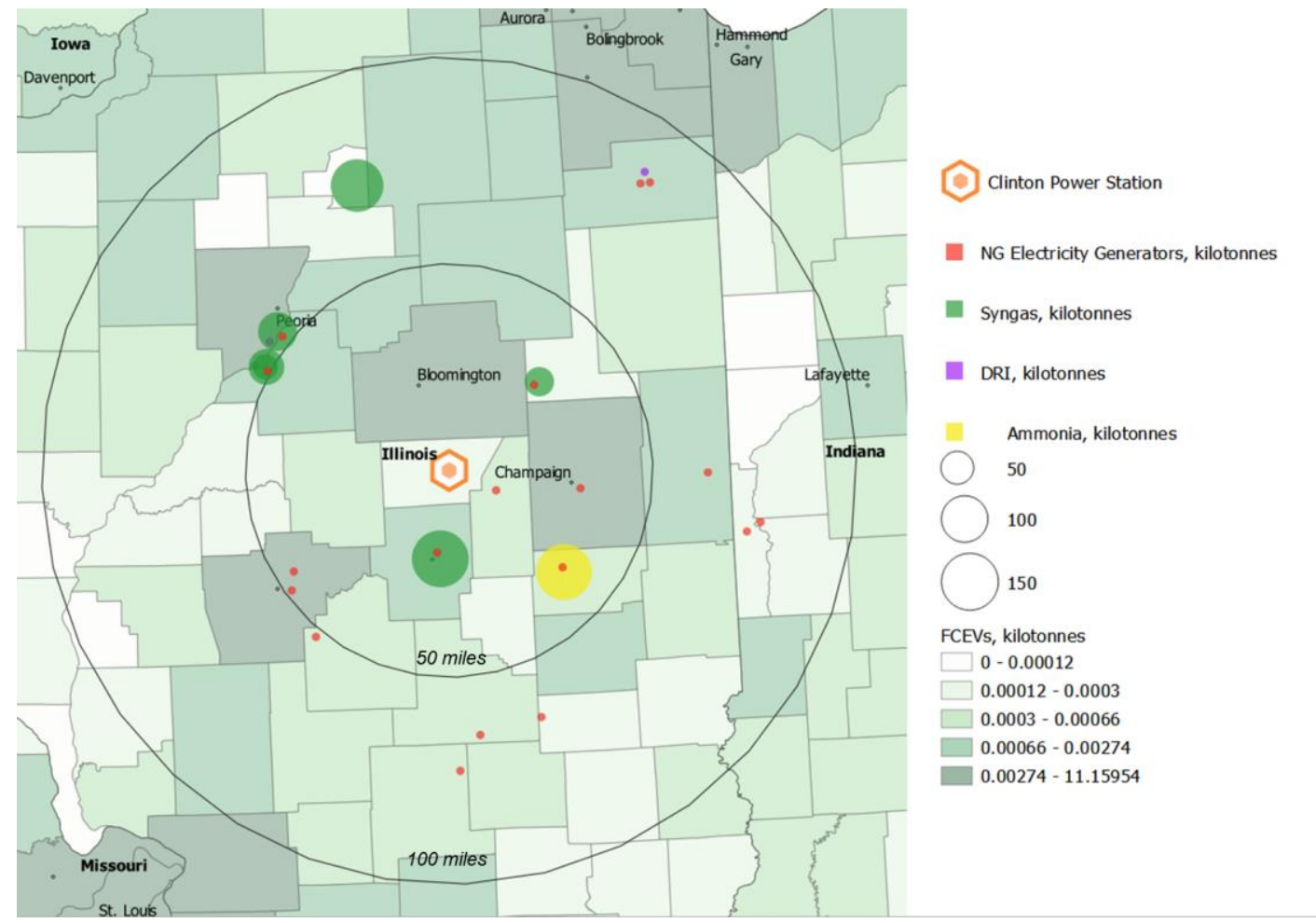

Figure 21 Future potential hydrogen demand near the Clinton power plant.

\subsubsection{LaSalle NPP, Ottawa, IL}

The La Salle County generating station is surrounded by refineries, potential DRI opportunities, NG electricity generators, and ethanol-production facilities. The current potential hydrogen demand within 
100 miles of La Salle NPP is about 1100 MT/day, the majority of which comes from three refineries. There are about $63 \mathrm{NG}$ electricity generators, with a total potential demand of $300 \mathrm{MT} / \mathrm{day}$. The Kendall County generation facility alone accounts for a third of this total hydrogen demand.

The total cumulative future potential hydrogen demand is about $4000 \mathrm{MT} / \mathrm{day}$. There are three refineries near La Salle power plant with cumulative potential future hydrogen demand of about 840 MT/day. A refinery in Joliet, operated by ExxonMobil, may require 240 MT/day, PDV Americas in Lemont and BP PLC in Whiting may require 180 and 420 MT/day, respectively.

There are twelve opportunities for hydrogen in making DRI, with cumulative potential future hydrogen demand of 1400 MT/day within 100 miles. Five of these facilities-ArcelorMittal in Burns Harbor, the U.S. Steel-Gary Works (No. 1 BOP and Q-BOP), and three ArcelorMittal facilities at Indiana Harbor (2, 3, and 4) - make up more than half of that demand. Potential synfuel production at six ethanol plants, located within 100 miles, require about 1000 MT/day of hydrogen. The Marquis Energy LLC in Hennepin is closest to the LaSalle NPP, only 35 miles away, with a potential hydrogen demand of $350 \mathrm{MT} / \mathrm{day}$.

Table 5 delineates the point-source demand for hydrogen near the LaSalle NPP while Figure 22 shows the potential hydrogen demand, and Figure 23 illustrates the potential for future growth. 
Table 5 Hydrogen demand within 100 miles of the LaSalle County generating station.

\begin{tabular}{|c|c|c|c|c|}
\hline \multirow[b]{2}{*}{ Name } & \multirow[b]{2}{*}{ Demand Type } & \multicolumn{2}{|c|}{$\begin{array}{l}\text { Potential } \mathrm{H} 2 \\
\text { Demand, kilotonnes }\end{array}$} & \multirow[b]{2}{*}{$\begin{array}{l}\text { Distance, } \\
\text { miles }\end{array}$} \\
\hline & & $\begin{array}{l}\text { Current } \\
(2017)\end{array}$ & $\begin{array}{l}\text { Future } \\
(2030)\end{array}$ & \\
\hline LaSalle County, IL & FCEV & - & 0.00 & 19 \\
\hline Grundy County, IL & FCEV & - & 0.00 & 25 \\
\hline Morris Cogeneration LLC: Morris Cogeneration LLC & NG Electricity Generators & 5.73 & 5.73 & 29 \\
\hline Livingston County, IL & FCEV & - & 0.00 & 30 \\
\hline Kendall County Generation Facility: Dynegy Kendall Energy LLC & NG Electricity Generators & 37.86 & 37.86 & 34 \\
\hline Marquis Energy LLC, Hennepin & Syngas: Ethanol & - & 130.00 & 34 \\
\hline Putnam County, IL & FCEV & - & 0.00 & 37 \\
\hline Kendall County, IL & FCEV & - & 0.00 & 41 \\
\hline Air Products and Chemicals, Inc. - Joliet, Il H2 Plant & Syngas: Hydrogen, SMR & - & 7.11 & 42 \\
\hline Joliet 29: Midwest Generations EME LLC & NG Electricity Generators & 2.41 & 2.41 & 42 \\
\hline ExxonMobil Oil Joliet Refinery: ExxonMobil Oil Corp & NG Electricity Generators & 0.13 & 0.13 & 43 \\
\hline ExxonMobil Corp, Joliet & Refinery & 69.98 & 88.66 & 43 \\
\hline Joliet 9: Midwest Generations EME LLC & NG Electricity Generators & 0.41 & 0.41 & 44 \\
\hline Hennepin Power Plant: Dynegy Midwest Generation Inc & NG Electricity Generators & 0.06 & 0.06 & 45 \\
\hline Fox Metro Water Reclamation District: Fox Metro Water Reclamation & NG Electricity Generators & 0.00 & 0.00 & 45 \\
\hline CSL Behring LLC: CSL Behring LLC & NG Electricity Generators & 0.21 & 0.21 & 49 \\
\hline Will County, IL & FCEV & - & 0.01 & 50 \\
\hline Marshall County, IL & FCEV & - & 0.00 & 50 \\
\hline WestRock (IL): WestRock (IL) & NG Electricity Generators & 0.00 & 0.00 & 51 \\
\hline Nucor Steel - Kankakee Inc. & DRI & 0.56 & 1.99 & 52 \\
\hline Elwood Energy LLC: Elwood Energy LLC & NG Electricity Generators & 3.05 & 3.05 & 52 \\
\hline Linde Gas North America LLC, Lemont Plant & Syngas: Hydrogen, SMR & - & 46.03 & 53 \\
\hline Bureau County, IL & FCEV & - & 0.00 & 53 \\
\hline Princeton (IL): City of Princeton - (IL) & NG Electricity Generators & 0.01 & 0.01 & 54 \\
\hline Kankakee County, IL & FCEV & - & 0.00 & 55 \\
\hline
\end{tabular}




\begin{tabular}{|c|c|c|c|c|}
\hline Lemont Refinery & Syngas: Hydrogen, SMR & - & 6.71 & 55 \\
\hline Bunge Oil: CSL Behring LLC & NG Electricity Generators & 0.18 & 0.18 & 55 \\
\hline Lincoln Generating Facility: Lincoln Generating Facility LLC & NG Electricity Generators & 0.27 & 0.27 & 56 \\
\hline Woodridge Greene Valley Treatment Plant: DuPage County & NG Electricity Generators & 0.00 & 0.00 & 58 \\
\hline Aurora: Aurora Generation LLC & NG Electricity Generators & 3.20 & 3.20 & 58 \\
\hline University Park South: University Park Energy LLC & NG Electricity Generators & 1.40 & 1.40 & 59 \\
\hline University Park North: LSP University Park LLC & NG Electricity Generators & 3.59 & 3.59 & 59 \\
\hline Nalco: Nalco Co & NG Electricity Generators & 0.17 & 0.17 & 59 \\
\hline Kane County, IL & FCEV & - & 0.01 & 60 \\
\hline PDV America Inc, Lemont & Refinery & 51.60 & 65.38 & 61 \\
\hline McLean County, IL & FCEV & - & 0.00 & 61 \\
\hline Argonne National Laboratory CHP: Argonne National Laboratory & NG Electricity Generators & 0.31 & 0.31 & 61 \\
\hline DeKalb County, IL & FCEV & - & 0.00 & 61 \\
\hline Geneva Generation Facility: City of Geneva- (IL) & NG Electricity Generators & 0.02 & 0.02 & 61 \\
\hline Panduit Tinley Park: Panduit Corp & NG Electricity Generators & 0.00 & 0.00 & 63 \\
\hline Crete Energy Venture LLC: Crete Energy Venture LLC & NG Electricity Generators & 0.34 & 0.34 & 66 \\
\hline Woodford County, IL & FCEV & - & 0.00 & 66 \\
\hline Hoffer Plastics: Hoffer Plastics & NG Electricity Generators & 0.01 & 0.01 & 67 \\
\hline DuPage County, IL & FCEV & - & 0.02 & 68 \\
\hline One Earth Energy LLC, Gibson City & Syngas: Ethanol & - & 40.00 & 69 \\
\hline Illinois River Energy LLC, Rochelle & Syngas: Ethanol & - & 40.00 & 69 \\
\hline Gibson City Energy Center LLC: Mainline Generation LLC & NG Electricity Generators & 0.45 & 0.45 & 69 \\
\hline BP Naperville Cogeneration Facility: BP America Inc & NG Electricity Generators & 0.66 & 0.66 & 70 \\
\hline Elgin Energy Center LLC: Elgin Energy Center LLC & NG Electricity Generators & 1.27 & 1.27 & 70 \\
\hline 1515 S Caron Road: Rochelle Municipal Utilities & NG Electricity Generators & 0.00 & 0.00 & 70 \\
\hline Lee County, IL & FCEV & - & 0.00 & 71 \\
\hline Ingredion Incorporated: Ingredion Inc - Illinois & NG Electricity Generators & 1.68 & 1.68 & 71 \\
\hline Stark County, IL & FCEV & - & 0.00 & 72 \\
\hline Lee Energy Facility: Lee County Generating Station & NG Electricity Generators & 0.87 & 0.87 & 72 \\
\hline
\end{tabular}




\begin{tabular}{|c|c|c|c|c|}
\hline North Ninth Street: Rochelle Municipal Utilities & NG Electricity Generators & 0.01 & 0.01 & 73 \\
\hline South Main Street: Rochelle Municipal Utilities & NG Electricity Generators & 0.00 & 0.00 & 73 \\
\hline ArcelorMittal - Riverdale & DRI & 1.63 & 23.04 & 74 \\
\hline Ford County, IL & FCEV & - & 0.00 & 74 \\
\hline Loyola University Health Plant: Loyola University Health System & NG Electricity Generators & 1.50 & 1.50 & 74 \\
\hline Patriot Renewable Fuels LLC, Annawan & Syngas: Ethanol & - & 50.00 & 76 \\
\hline Iroquois County, IL & FCEV & - & 0.00 & 77 \\
\hline Finkl Steel & DRI & 0.07 & 0.23 & 79 \\
\hline Chicago West Side Energy Center: Energy Systems Group LLC & NG Electricity Generators & 0.14 & 0.14 & 80 \\
\hline Triton East and West Cogen: Triton College & NG Electricity Generators & 0.05 & 0.05 & 80 \\
\hline Calumet Energy Team LLC: IPA Operations Inc - Calumet & NG Electricity Generators & 0.19 & 0.19 & 80 \\
\hline Cook County, IL & FCEV & - & 0.10 & 80 \\
\hline ITT Cogen Facility: Illinois Institute-Technology & NG Electricity Generators & 0.00 & 0.00 & 81 \\
\hline University of Illinois Cogen Facility: University of Illinois & NG Electricity Generators & 0.58 & 0.58 & 81 \\
\hline Mars Snackfood US: M\&M Mars Inc & NG Electricity Generators & 0.32 & 0.32 & 81 \\
\hline Adm Peoria Il, Peoria & Syngas: Ethanol & - & 70.00 & 83 \\
\hline Archer Daniels Midland Peoria: Archer Daniels Midland Co & NG Electricity Generators & 2.19 & 2.19 & 83 \\
\hline Peoria County, IL & FCEV & - & 0.00 & 84 \\
\hline Lake County, IN & FCEV & - & 0.01 & 84 \\
\hline Presence Saint Mary of Nazareth Hospital: Presence Health & NG Electricity Generators & 0.00 & 0.00 & 84 \\
\hline Museum of Science and Industry: Museum of Science and Industry & NG Electricity Generators & 0.00 & 0.00 & 85 \\
\hline Southeast Chicago Energy Project: Exelon Power & NG Electricity Generators & 0.27 & 0.27 & 85 \\
\hline Charter Dura-Bar: Wells Manufacturing Co & NG Electricity Generators & 0.07 & 0.07 & 85 \\
\hline Big River Resources Galva LLC, Galva & Syngas: Ethanol & - & 40.00 & 86 \\
\hline ArcelorMittal - Indiana Harbor \#2 & DRI & 3.25 & 46.10 & 86 \\
\hline ArcelorMittal - Indiana Harbor \#3 & DRI & 4.39 & 62.22 & 86 \\
\hline ArcelorMittal - Indiana Harbor \#4 & DRI & 5.37 & 76.06 & 86 \\
\hline ArcelorMittal - Indiana Harbor Bar & DRI & 0.34 & 1.19 & 86 \\
\hline Nelson Energy Center: Invenergy Services LLC & NG Electricity Generators & 11.75 & 11.75 & 86 \\
\hline
\end{tabular}




\begin{tabular}{|c|c|c|c|c|}
\hline Northwest Community Hospital: Northwest Community Hospital & NG Electricity Generators & 0.08 & 0.08 & 87 \\
\hline McHenry County, IL & FCEV & - & 0.01 & 87 \\
\hline Newton County, IN & FCEV & - & 0.00 & 87 \\
\hline $\begin{array}{l}\text { ArcelorMittal Indiana Harbor West: ArcelorMittal Indiana Harbor } \\
\text { West }\end{array}$ & NG Electricity Generators & 2.37 & 2.37 & 87 \\
\hline Praxair - Whiting, In 1-4 & Syngas: Hydrogen, SMR & - & 21.38 & 87 \\
\hline Praxair - Whiting, In $5 \& 6$ & Syngas: Hydrogen, SMR & - & 198.31 & 87 \\
\hline Bp PLC, Whiting & Refinery & 121.28 & 153.66 & 88 \\
\hline Bp Whiting Business Unit & Syngas: Hydrogen, SMR & - & - & 88 \\
\hline Whiting Refinery: BP PLC & NG Electricity Generators & 2.09 & 2.09 & 88 \\
\hline Whiting Clean Energy: BP Alternative Energy & NG Electricity Generators & 13.88 & 13.88 & 88 \\
\hline Goose Creek Energy Center: Union Electric Co - (MO) & NG Electricity Generators & 0.21 & 0.21 & 88 \\
\hline Ogle County, IL & FCEV & - & 0.00 & 88 \\
\hline Indiana Harbor E 5 AC Station: Northlake Energy & NG Electricity Generators & 1.23 & 1.23 & 89 \\
\hline Prairies Edge Generating Facility: Prairies Edge Dairy Farms LLC & NG Electricity Generators & 0.10 & 0.10 & 89 \\
\hline Gary Works: United States Steel-Gary & NG Electricity Generators & 3.79 & 3.79 & 90 \\
\hline US Steel - Gary Works (No. 1 BOP and Q-BOP) & DRI & 11.95 & 169.40 & 90 \\
\hline $\begin{array}{l}\text { Northeastern Illinois University Cogen: Northeastern Illinois } \\
\text { University }\end{array}$ & NG Electricity Generators & 0.00 & 0.00 & 90 \\
\hline Geneseo: City of Geneseo - (IL) & NG Electricity Generators & 0.00 & 0.00 & 91 \\
\hline Henry County, IL & FCEV & - & 0.00 & 92 \\
\hline Leggett and Platt Wire Rod (Formarly Sterling Steel Co. LLC) & DRI & 1.58 & 5.57 & 92 \\
\hline De Witt County, IL & FCEV & - & 0.00 & 92 \\
\hline Tazewell County, IL & FCEV & - & 0.00 & 92 \\
\hline Kishwaukee CHP Plant: Rock River Water Reclamation District & NG Electricity Generators & 0.01 & 0.01 & 95 \\
\hline Portside Energy: Portside Energy Corp & NG Electricity Generators & 2.82 & 2.82 & 95 \\
\hline Novolipetsk Steel (NLMK Indiana) & DRI & 0.53 & 1.87 & 95 \\
\hline Piatt County, IL & FCEV & - & 0.00 & 95 \\
\hline Rocky Road Power LLC: Rocky Road Power LLC & NG Electricity Generators & 0.15 & 0.15 & 96 \\
\hline ArcelorMittal - Burns Harbor & DRI & 9.10 & 129.07 & 96 \\
\hline
\end{tabular}




\begin{tabular}{|c|c|c|c|c|}
\hline NRG Rockford II Energy Center: Rockford Generation LLC & NG Electricity Generators & 0.61 & 0.61 & 96 \\
\hline NRG Rockford I: Rockford Generation LLC & NG Electricity Generators & 0.58 & 0.58 & 96 \\
\hline Jasper County, IN & FCEV & - & 0.00 & 96 \\
\hline ArcelorMittal Burns Harbor: ArcelorMittal Burns Harbor Inc & NG Electricity Generators & 3.81 & 3.81 & 97 \\
\hline Logan County, IL & FCEV & - & 0.00 & 97 \\
\hline Whiteside County, IL & FCEV & - & 0.00 & 97 \\
\hline Winnetka: Village of Winnetka - (IL) & NG Electricity Generators & 0.08 & 0.08 & 98 \\
\hline Champaign County, IL & FCEV & - & 0.00 & 98 \\
\hline Keystone Steel and Wire Co. & DRI & 0.88 & 3.10 & 98 \\
\hline Winnebago County, IL & FCEV & - & 0.01 & 99 \\
\hline Bailly: Northern Indiana Pub Serv Co & NG Electricity Generators & 0.36 & 0.36 & 99 \\
\hline University of Illinois Abbott Power Plt: University of Illinois & NG Electricity Generators & 2.26 & 2.26 & 100 \\
\hline
\end{tabular}




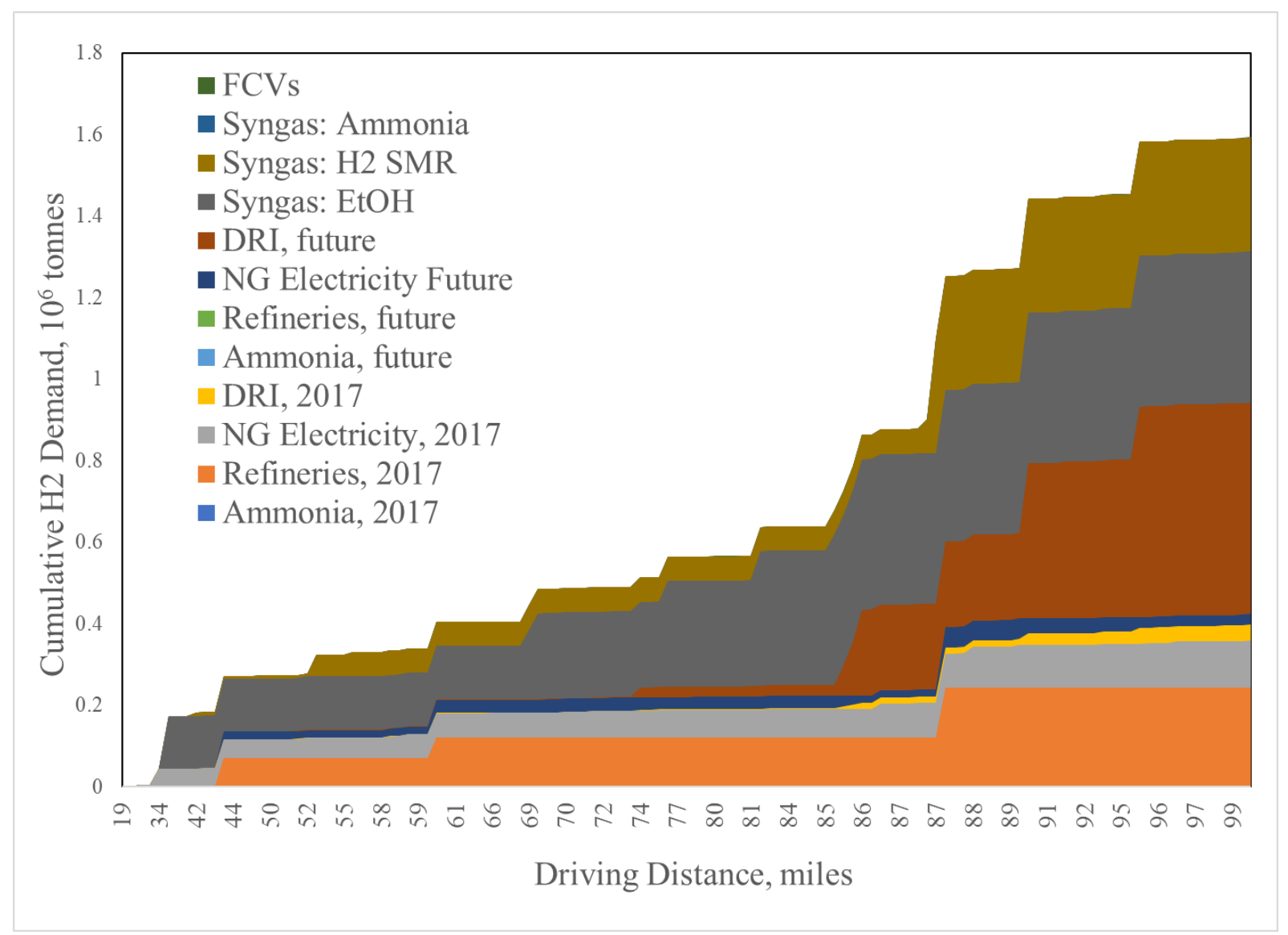

Figure 22. Cumulative potential hydrogen demand by type and distance near the La Salle generating station. 


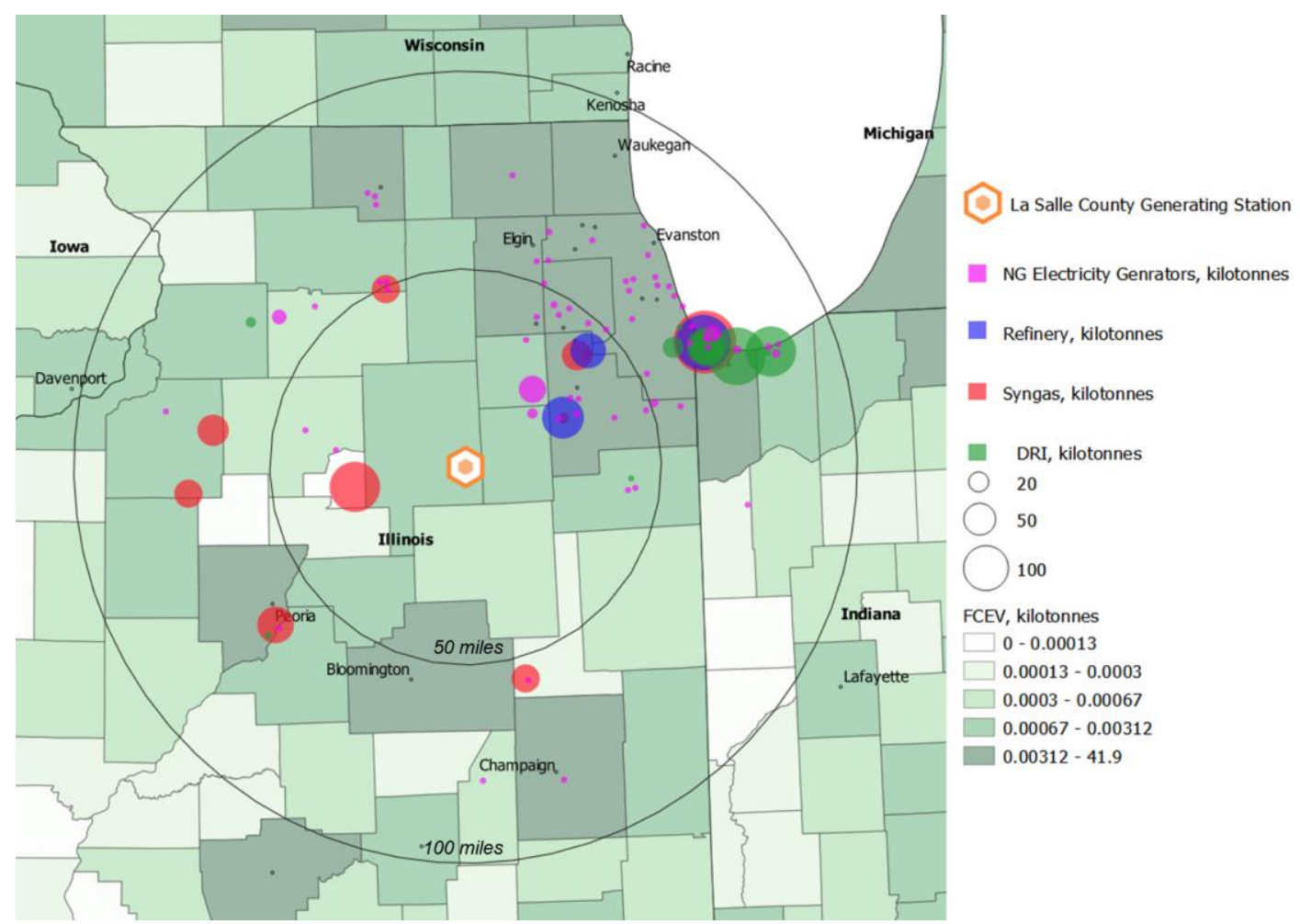

Figure 23 Future potential hydrogen demand near the La Salle NPP.

\subsubsection{Braidwood NPP, Joliet, IL}

Braidwood generating station produces approximately $2400 \mathrm{MW}$ of power and is the largest NPP in the state of Illinois. The Braidwood location's current potential hydrogen demand stems from DRI, refinery, and NG electricity generators, with a cumulative potential demand of $1047 \mathrm{MT} / \mathrm{day}$, mainly for the refineries proximate to the NPP. The refinery in Joliet, operated by ExxonMobil, currently has a potential demand of 200 MT/day while the PDV Americas in Lemont and the BP PLC in Whiting will require 140 and $330 \mathrm{MT} /$ day, respectively. The opportunities for DRI near the generating station has potential demand of about $100 \mathrm{MT} /$ day while the potential demand from sixty NG electricity generators is about $270 \mathrm{MT} /$ day.

The potential future hydrogen demand near the Braidwood generating station is about $3800 \mathrm{MT} / \mathrm{day}$, mainly from the additional demand by DRI plants and refineries. The future potential hydrogen demand, including possible synfuel production at ethanol and SMR plants, are estimated at 520 and 770 MMT/day, respectively. FCEVs in this region add less than 1 MT/day of potential demand (see Table 6.) Figure 24 and Figure 25 show graphically current potential and projected future demand near the Braidwood generating station. 


\begin{tabular}{|c|c|c|c|c|}
\hline Name & Demand Type & \multicolumn{3}{|c|}{$\begin{array}{l}\text { Potential H2 Demand, } \\
\text { kilotonnes }\end{array}$} \\
\hline Grundy County, IL & FCEV & - & 0.0 & 14 \\
\hline ExxonMobil Oil Joliet Refinery: ExxonMobil Oil Corp & NG Electricity Generators & 0.1 & 0.1 & 15 \\
\hline ExxonMobil Corp, Joliet & Refinery & 70.0 & 88.7 & 15 \\
\hline Joliet 29: Midwest Generations EME LLC & NG Electricity Generators & 2.4 & 2.4 & 21 \\
\hline Kendall County Generation Facility: Dynegy Kendall Energy LLC & NG Electricity Generators & 37.9 & 37.9 & 22 \\
\hline Morris Cogeneration LLC: Morris Cogeneration LLC & NG Electricity Generators & 5.7 & 5.7 & 23 \\
\hline Joliet 9: Midwest Generations EME LLC & NG Electricity Generators & 0.4 & 0.4 & 24 \\
\hline Lincoln Generating Facility: Lincoln Generating Facility LLC & NG Electricity Generators & 0.3 & 0.3 & 24 \\
\hline Will County, IL & FCEV & - & 0.0 & 32 \\
\hline Linde Gas North America LLC, Lemont Plant & Syngas: Hydrogen, SMR & - & 46.0 & 34 \\
\hline University Park North: LSP University Park LLC & NG Electricity Generators & 3.6 & 3.6 & 35 \\
\hline University Park South: University Park Energy LLC & NG Electricity Generators & 1.4 & 1.4 & 35 \\
\hline Lemont Refinery & Syngas: Hydrogen, SMR & - & 6.7 & 37 \\
\hline Livingston County, IL & FCEV & - & 0.0 & 39 \\
\hline Woodridge Greene Valley Treatment Plant: DuPage County & NG Electricity Generators & 0.0 & 0.0 & 39 \\
\hline Fox Metro Water Reclamation District: Fox Metro Water Reclamation & NG Electricity Generators & 0.0 & 0.0 & 41 \\
\hline Kendall County, IL & FCEV & - & 0.0 & 41 \\
\hline PDV America Inc, Lemont & Refinery & 51.6 & 65.4 & 42 \\
\hline
\end{tabular}




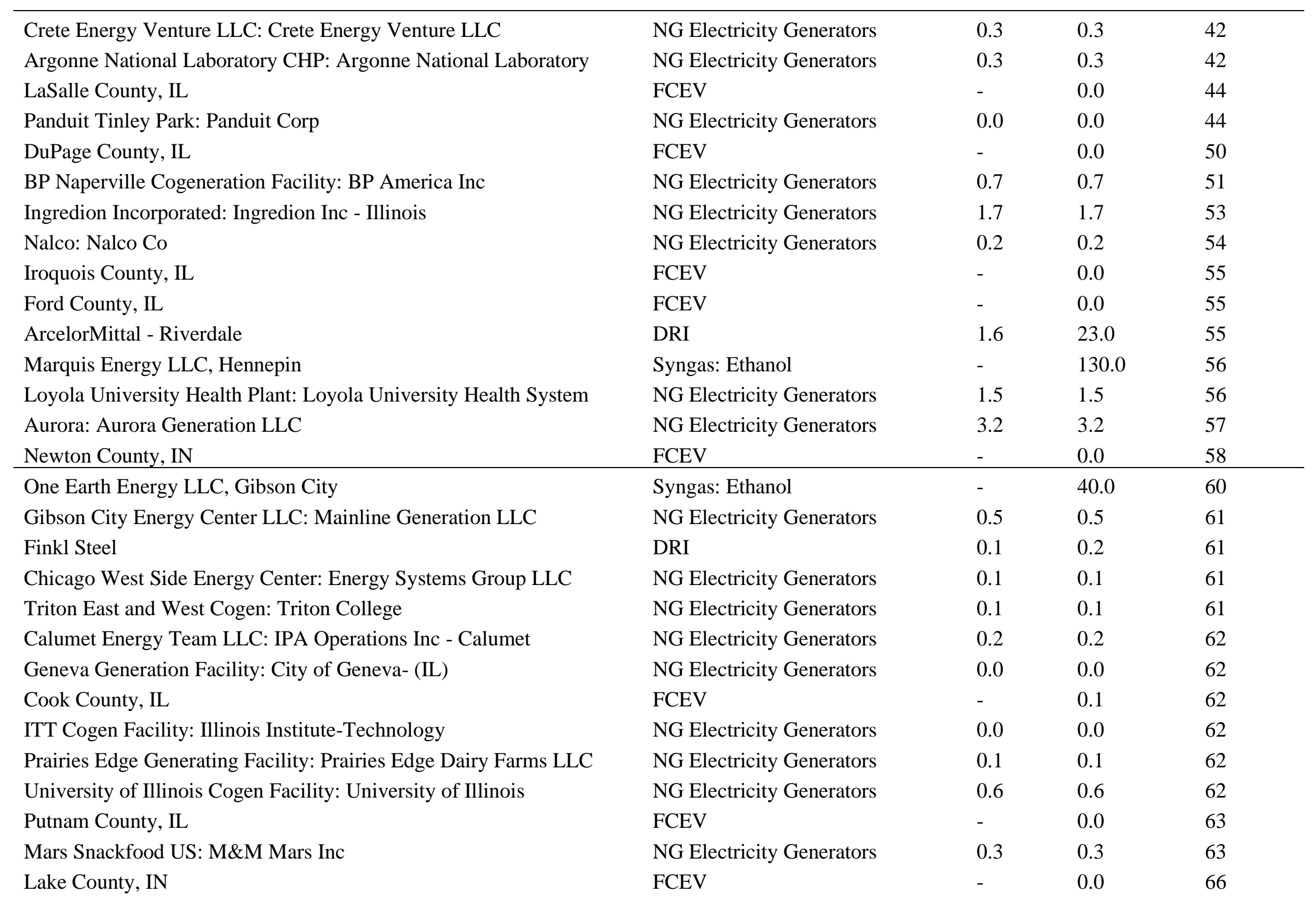




\begin{tabular}{|c|c|c|c|c|}
\hline Kane County, IL & FCEV & - & 0.0 & 66 \\
\hline Presence Saint Mary of Nazareth Hospital: Presence Health & NG Electricity Generators & 0.0 & 0.0 & 66 \\
\hline Museum of Science and Industry: Museum of Science and Industry & NG Electricity Generators & 0.0 & 0.0 & 67 \\
\hline ArcelorMittal - Indiana Harbor \#2 & DRI & 3.3 & 46.1 & 68 \\
\hline ArcelorMittal - Indiana Harbor \#3 & DRI & 4.4 & 62.2 & 68 \\
\hline ArcelorMittal - Indiana Harbor \#4 & DRI & 5.4 & 76.1 & 68 \\
\hline Northwest Community Hospital: Northwest Community Hospital & NG Electricity Generators & 0.1 & 0.1 & 68 \\
\hline $\begin{array}{l}\text { ArcelorMittal Indiana Harbor West: ArcelorMittal Indiana Harbor } \\
\text { West }\end{array}$ & NG Electricity Generators & 2.4 & 2.4 & 69 \\
\hline Jasper County, IN & FCEV & - & 0.0 & 69 \\
\hline Praxair - Whiting, In 1-4 & Syngas: Hydrogen, SMR & - & 21.4 & 69 \\
\hline Praxair - Whiting, In $5 \& 6$ & Syngas: Hydrogen, SMR & - & 198.3 & 69 \\
\hline Bp PLC, Whiting & Refinery & 121.3 & 153.7 & 69 \\
\hline Bp Whiting Business Unit & Syngas: Hydrogen, SMR & - & - & 69 \\
\hline Whiting Refinery: BP PLC & NG Electricity Generators & 2.1 & 2.1 & 69 \\
\hline Whiting Clean Energy: BP Alternative Energy & NG Electricity Generators & 13.9 & 13.9 & 70 \\
\hline Gary Works: United States Steel-Gary & NG Electricity Generators & 3.8 & 3.8 & 70 \\
\hline Marshall County, IL & FCEV & - & 0.0 & 70 \\
\hline Indiana Harbor E 5 AC Station: Northlake Energy & NG Electricity Generators & 1.2 & 1.2 & 70 \\
\hline Hennepin Power Plant: Dynegy Midwest Generation Inc & NG Electricity Generators & 0.1 & 0.1 & 71 \\
\hline US Steel - Gary Works (No. 1 BOP and Q-BOP) & DRI & 11.9 & 169.4 & 71 \\
\hline $\begin{array}{l}\text { Northeastern Illinois University Cogen: Northeastern Illinois } \\
\text { University }\end{array}$ & NG Electricity Generators & 0.0 & 0.0 & 72 \\
\hline Rensselaer City Light Plant: City of Rensselaer - (IN) & NG Electricity Generators & 0.0 & 0.0 & 72 \\
\hline McLean County, IL & FCEV & - & 0.0 & 73 \\
\hline Elgin Energy Center LLC: Elgin Energy Center LLC & NG Electricity Generators & 1.3 & 1.3 & 73 \\
\hline R M Schahfer: Northern Indiana Pub Serv Co & NG Electricity Generators & 0.4 & 0.4 & 76 \\
\hline Hoffer Plastics: Hoffer Plastics & NG Electricity Generators & 0.0 & 0.0 & 76 \\
\hline
\end{tabular}




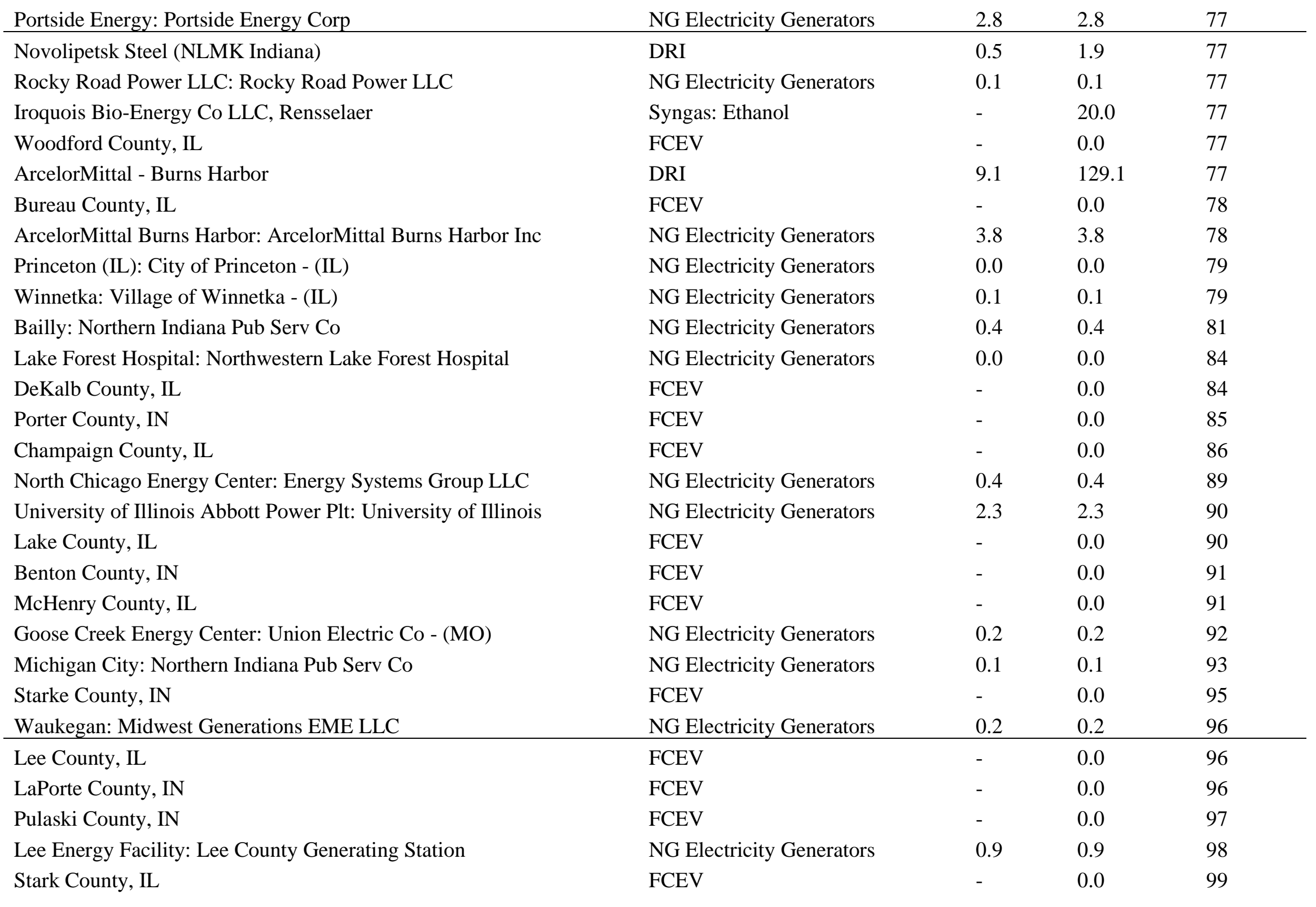


Charter Dura-Bar: Wells Manufacturing Co

White County, IN

NG Electricity Generators

FCEV

0.1

-
0.1

0.0
99

100 


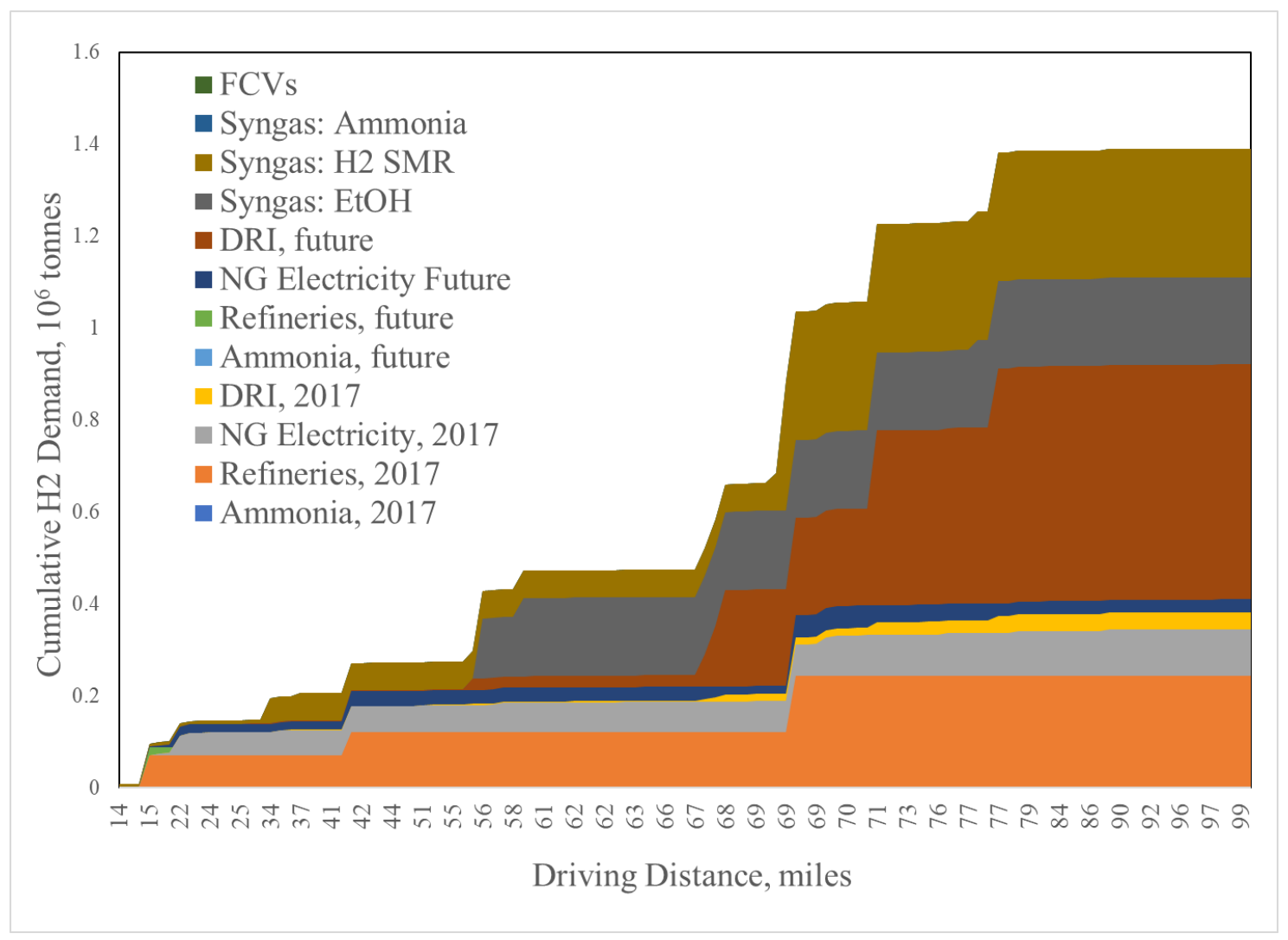

Figure 24 Cumulative potential hydrogen demand by type and distance near the Braidwood generating station.

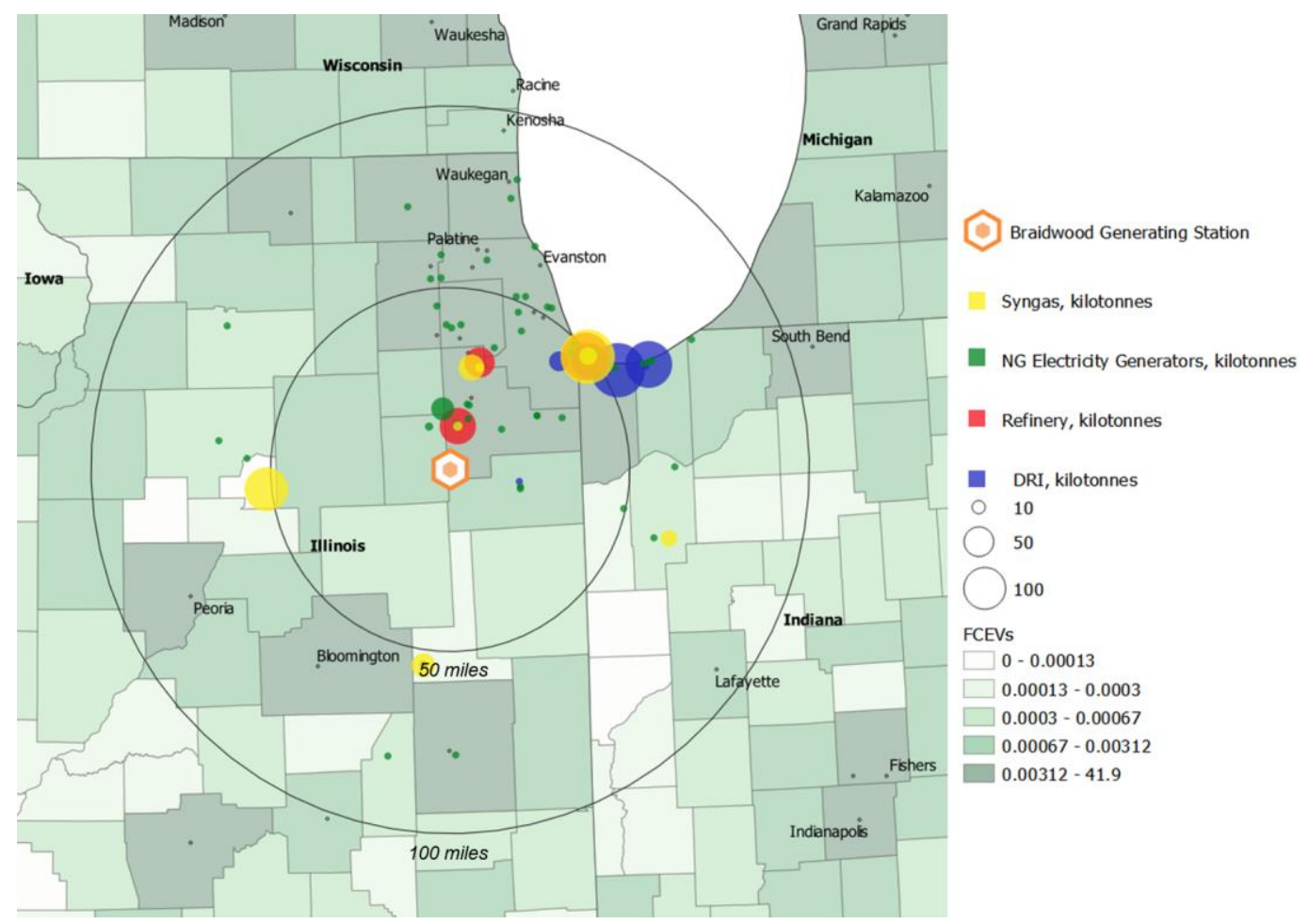

Figure 25 Future potential hydrogen demand near the Braidwood generating station. 


\subsubsection{Byron NPP, Rockford, IL}

The Byron generating station has a potential hydrogen demand of 530 MT/day. NG electricity generators, refineries, and ammonia production account for almost the entire current potential demand, each having a demand of 230, 140, and 160 MT/day, respectively. The PDV America, Inc., refinery in Lemont, the CVR Partners ammonia production facility in East Dubuque, and the Kendall County generation facility (90 miles driving distance from the NPP) together represent almost the entire current potential hydrogen demand. (See Table 7 and Figure 26).

The future potential demand for Byron is about 2100 MT/day, the majority of which could be for synfuel production, near current ethanol plants accounting for $1200 \mathrm{MT} / \mathrm{day}$, near hydrogen SMR plants accounting for $145 \mathrm{MT} / \mathrm{day}$, and near ammonia plants accounting for $155 \mathrm{MT} /$ day (see Figure 27). 


\begin{tabular}{|c|c|c|c|c|}
\hline \multirow[b]{2}{*}{ Name } & \multirow[b]{2}{*}{ Demand Type } & \multicolumn{2}{|c|}{$\begin{array}{c}\text { Potential H2 } \\
\text { Demand, kilotonnes }\end{array}$} & \multirow[b]{2}{*}{$\begin{array}{c}\text { Distance, } \\
\text { miles }\end{array}$} \\
\hline & & $\begin{array}{l}\text { Current } \\
(2017)\end{array}$ & $\begin{array}{l}\text { Future } \\
(2030)\end{array}$ & \\
\hline Ogle County, IL & FCEV & - & 0.00 & 5 \\
\hline Kishwaukee CHP Plant: Rock River Water Reclamation District & NG Electricity Generators & 0.01 & 0.01 & 17 \\
\hline NRG Rockford II Energy Center: Rockford Generation LLC & NG Electricity Generators & 0.61 & 0.61 & 17 \\
\hline NRG Rockford I: Rockford Generation LLC & NG Electricity Generators & 0.58 & 0.58 & 17 \\
\hline Winnebago County, IL & FCEV & - & 0.01 & 23 \\
\hline Lee Energy Facility: Lee County Generating Station & NG Electricity Generators & 0.87 & 0.87 & 24 \\
\hline 1515 S Caron Road: Rochelle Municipal Utilities & NG Electricity Generators & 0.00 & 0.00 & 24 \\
\hline North Ninth Street: Rochelle Municipal Utilities & NG Electricity Generators & 0.01 & 0.01 & 24 \\
\hline South Main Street: Rochelle Municipal Utilities & NG Electricity Generators & 0.00 & 0.00 & 24 \\
\hline Lee County, IL & FCEV & - & 0.00 & 25 \\
\hline Illinois River Energy LLC, Rochelle & Syngas: Ethanol & - & 40.00 & 26 \\
\hline Nelson Energy Center: Invenergy Services LLC & NG Electricity Generators & 11.75 & 11.75 & 32 \\
\hline Boone County, IL & FCEV & - & 0.00 & 33 \\
\hline Leggett and Platt Wire Rod (Formarly Sterling Steel Co. LLC) & DRI & 1.58 & 5.57 & 37 \\
\hline Stephenson County, IL & FCEV & - & 0.00 & 37 \\
\hline DeKalb County, IL & FCEV & - & 0.00 & 39 \\
\hline Carroll County, IL & FCEV & - & 0.00 & 45 \\
\hline Adkins Energy LLC, Adkins Energy & Syngas: Ethanol & - & 20.00 & 46 \\
\hline Adkins Energy LLC: Adkins Energy LLC & NG Electricity Generators & 0.30 & 0.30 & 46 \\
\hline Whiteside County, IL & FCEV & - & 0.00 & 47 \\
\hline Rock River: Wisconsin Power and Light Co & NG Electricity Generators & 0.20 & 0.20 & 51 \\
\hline Riverside Energy Center: Wisconsin Power and Light Co & NG Electricity Generators & 7.12 & 7.12 & 52 \\
\hline Rock County, WI & FCEV & - & 0.00 & 55 \\
\hline Badger State Ethanol LLC, Monroe & Syngas: Ethanol & - & 20.00 & 56 \\
\hline Kane County, IL & FCEV & - & 0.01 & 56 \\
\hline
\end{tabular}




\begin{tabular}{|c|c|c|c|c|}
\hline Princeton (IL): City of Princeton - (IL) & NG Electricity Generators & 0.01 & 0.01 & 57 \\
\hline Charter Dura-Bar: Wells Manufacturing Co & NG Electricity Generators & 0.07 & 0.07 & 57 \\
\hline Bureau County, IL & FCEV & - & 0.00 & 58 \\
\hline McHenry County, IL & FCEV & - & 0.01 & 58 \\
\hline Green County, WI & FCEV & - & 0.00 & 59 \\
\hline Hoffer Plastics: Hoffer Plastics & NG Electricity Generators & 0.01 & 0.01 & 60 \\
\hline United Ethanol LLC, Milton & Syngas: Ethanol & - & 20.00 & 63 \\
\hline Elgin Energy Center LLC: Elgin Energy Center LLC & NG Electricity Generators & 1.27 & 1.27 & 64 \\
\hline Adm Clinton Ia, Clinton & Syngas: Ethanol & - & 90.00 & 64 \\
\hline Milton L Kapp: Interstate Power and Light Co & NG Electricity Generators & 0.25 & 0.25 & 65 \\
\hline Rocky Road Power LLC: Rocky Road Power LLC & NG Electricity Generators & 0.15 & 0.15 & 66 \\
\hline WestRock (IL): WestRock (IL) & NG Electricity Generators & 0.00 & 0.00 & 69 \\
\hline Clinton County, IA & FCEV & - & 0.00 & 69 \\
\hline Fox Metro Water Reclamation District: Fox Metro Water Reclamation & NG Electricity Generators & 0.00 & 0.00 & 70 \\
\hline Walworth County, WI & FCEV & - & 0.00 & 70 \\
\hline Aurora: Aurora Generation LLC & NG Electricity Generators & 3.20 & 3.20 & 71 \\
\hline Sheepskin: Wisconsin Power and Light Co & NG Electricity Generators & 0.04 & 0.04 & 71 \\
\hline Kendall County, IL & FCEV & - & 0.00 & 72 \\
\hline Nalco: Nalco Co & NG Electricity Generators & 0.17 & 0.17 & 72 \\
\hline Cordova Energy: Cordova Energy Co LLC & NG Electricity Generators & 0.42 & 0.42 & 73 \\
\hline Geneva Generation Facility: City of Geneva- (IL) & NG Electricity Generators & 0.02 & 0.02 & 74 \\
\hline LaSalle County, IL & FCEV & - & 0.00 & 74 \\
\hline BP Naperville Cogeneration Facility: BP America Inc & NG Electricity Generators & 0.66 & 0.66 & 74 \\
\hline Jo Daviess County, IL & FCEV & - & 0.00 & 75 \\
\hline Patriot Renewable Fuels LLC, Annawan & Syngas: Ethanol & - & 50.00 & 76 \\
\hline LSP-Whitewater LP: Whitewater Operating Services LLC & NG Electricity Generators & 3.71 & 3.71 & 77 \\
\hline RockGen Energy Center: Calpine -RockGen Energy & NG Electricity Generators & 3.22 & 3.22 & 78 \\
\hline Lafayette County, WI & FCEV & - & 0.00 & 78 \\
\hline Northwest Community Hospital: Northwest Community Hospital & NG Electricity Generators & 0.08 & 0.08 & 78 \\
\hline
\end{tabular}




\begin{tabular}{|c|c|c|c|c|}
\hline DuPage County, IL & FCEV & - & 0.02 & 81 \\
\hline Putnam County, IL & FCEV & - & 0.00 & 84 \\
\hline Marquis Energy LLC, Hennepin & Syngas: Ethanol & - & 130.00 & 84 \\
\hline Geneseo: City of Geneseo - (IL) & NG Electricity Generators & 0.00 & 0.00 & 85 \\
\hline Woodridge Greene Valley Treatment Plant: DuPage County & NG Electricity Generators & 0.00 & 0.00 & 85 \\
\hline Jackson County, IA & FCEV & - & 0.00 & 85 \\
\hline Jefferson County, WI & FCEV & - & 0.00 & 86 \\
\hline Valero Renewable Fuels LLC, Jefferson Plant & Syngas: Ethanol & - & 40.00 & 86 \\
\hline Maquoketa 1: City of Maquoketa - (IA) & NG Electricity Generators & 0.00 & 0.00 & 87 \\
\hline Hennepin Power Plant: Dynegy Midwest Generation Inc & NG Electricity Generators & 0.06 & 0.06 & 88 \\
\hline Kendall County Generation Facility: Dynegy Kendall Energy LLC & NG Electricity Generators & 37.86 & 37.86 & 90 \\
\hline Riverside: MidAmerican Energy Co & NG Electricity Generators & 0.09 & 0.09 & 90 \\
\hline Moline: MidAmerican Energy Co & NG Electricity Generators & 0.01 & 0.01 & 91 \\
\hline PDV America Inc, Lemont & Refinery & 51.60 & 65.38 & 91 \\
\hline Triton East and West Cogen: Triton College & NG Electricity Generators & 0.05 & 0.05 & 91 \\
\hline Argonne National Laboratory CHP: Argonne National Laboratory & NG Electricity Generators & 0.31 & 0.31 & 91 \\
\hline Nine Springs: Madison Gas and Electric Co & NG Electricity Generators & 0.01 & 0.01 & 92 \\
\hline Stark County, IL & FCEV & - & 0.00 & 92 \\
\hline Rock Island County, IL & FCEV & - & 0.00 & 92 \\
\hline Zion Energy Center: Zion Energy LLC & NG Electricity Generators & 3.83 & 3.83 & 92 \\
\hline Henry County, IL & FCEV & - & 0.00 & 92 \\
\hline Linde Gas North America LLC, Lemont Plant & Syngas: Hydrogen, SMR & - & 46.03 & 92 \\
\hline Mars Snackfood US: M\&M Mars Inc & NG Electricity Generators & 0.32 & 0.32 & 93 \\
\hline Lemont Refinery & Syngas: Hydrogen, SMR & - & 6.71 & 93 \\
\hline Loyola University Health Plant: Loyola University Health System & NG Electricity Generators & 1.50 & 1.50 & 93 \\
\hline Cvr Partners, East Dubuque & Ammonia & 57.00 & 57.00 & 93 \\
\hline Cvr Partners, East Dubuque & Syngas: Ammonia CO2 & - & 52.87 & 93 \\
\hline $\begin{array}{l}\text { Northeastern Illinois University Cogen: Northeastern Illinois } \\
\text { University }\end{array}$ & NG Electricity Generators & 0.00 & 0.00 & 94 \\
\hline Sycamore (WI): Madison Gas and Electric Co & NG Electricity Generators & 0.00 & 0.00 & 94 \\
\hline
\end{tabular}




\begin{tabular}{|c|c|c|c|c|}
\hline Dane County, WI & FCEV & - & 0.01 & 95 \\
\hline Blount Street: Madison Gas and Electric Co & NG Electricity Generators & 0.24 & 0.24 & 95 \\
\hline UW Madison Charter Street Plant: State of Wisconsin & NG Electricity Generators & 2.46 & 2.46 & 95 \\
\hline Cook County, IL & FCEV & - & 0.10 & 96 \\
\hline West Campus Cogeneration Facility: Madison Gas and Electric Co & NG Electricity Generators & 2.58 & 2.58 & 96 \\
\hline Presence Saint Mary of Nazareth Hospital: Presence Health & NG Electricity Generators & 0.00 & 0.00 & 97 \\
\hline Scott County, IA & FCEV & - & 0.00 & 97 \\
\hline Big River Resources Galva LLC, Galva & Syngas: Ethanol & - & 40.00 & 97 \\
\hline Concord: Wisconsin Electric Power Co & NG Electricity Generators & 0.87 & 0.87 & 97 \\
\hline Will County, IL & FCEV & - & 0.01 & 98 \\
\hline Lake County, IL & FCEV & - & 0.01 & 98 \\
\hline Dubuque: Interstate Power and Light Co & NG Electricity Generators & 0.00 & 0.00 & 99 \\
\hline Marshall County, IL & FCEV & - & 0.00 & 100 \\
\hline
\end{tabular}




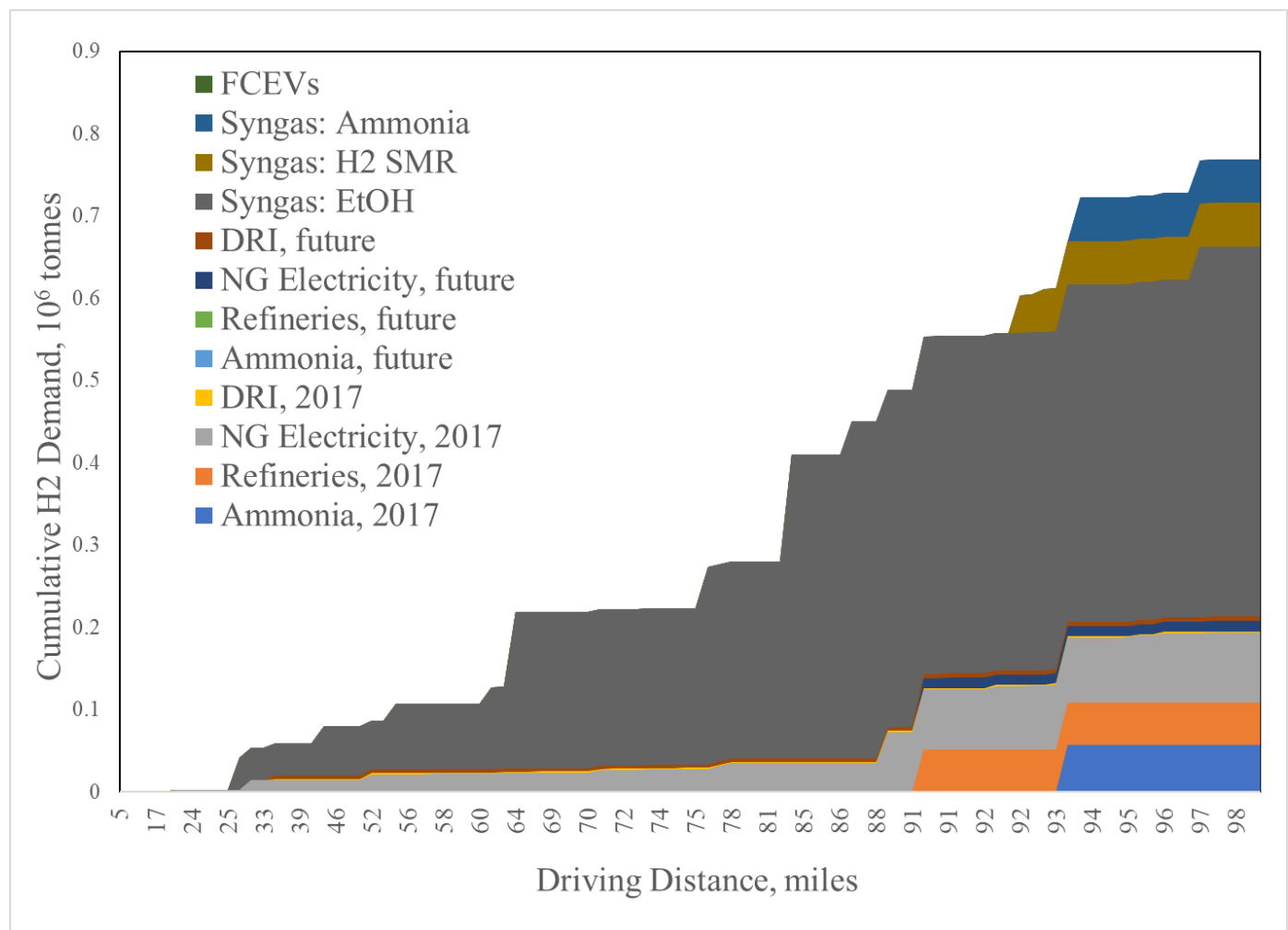

Figure 26. Cumulative potential hydrogen demand by type and distance near the Byron generating station.

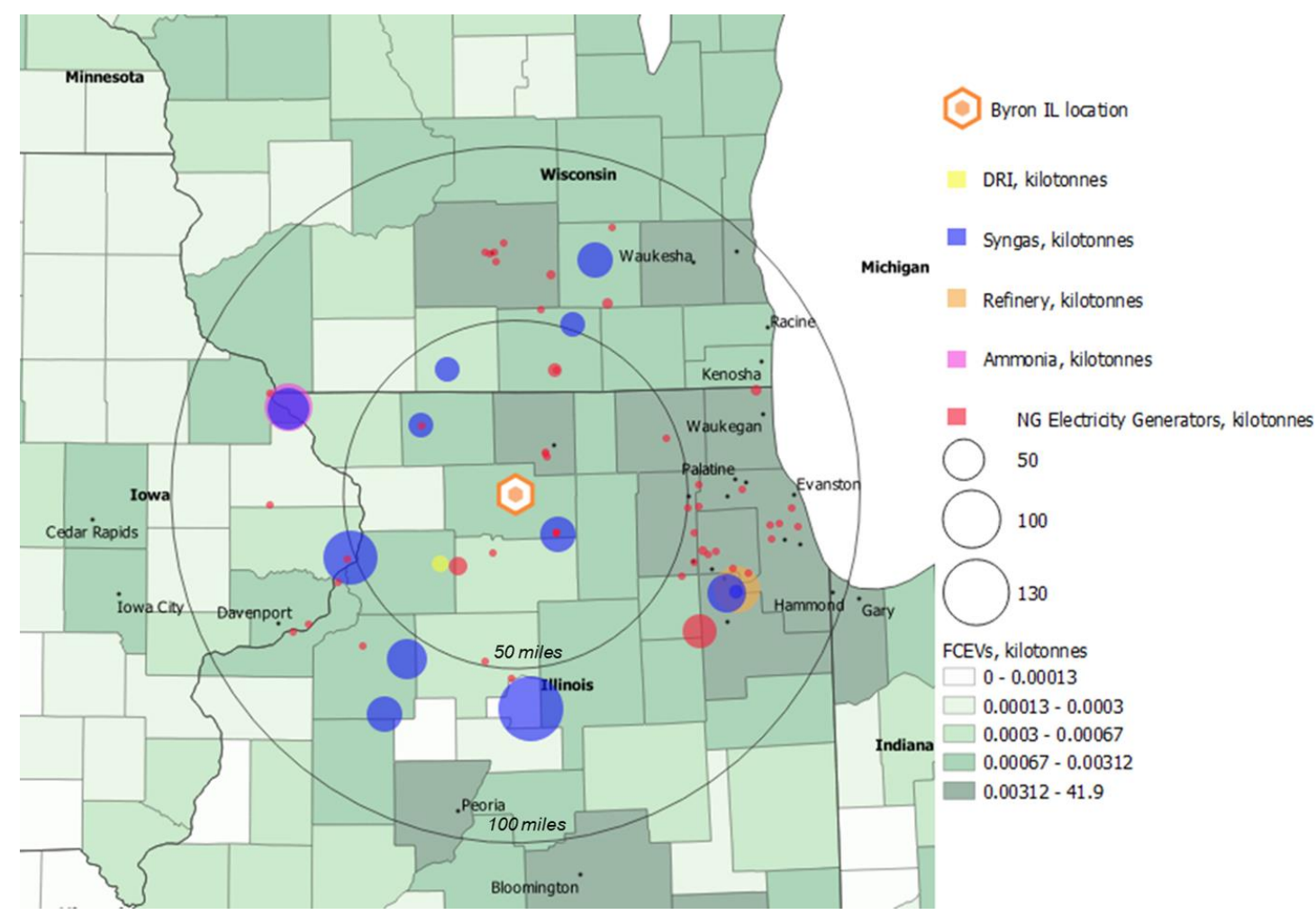

Figure 27 Future potential hydrogen demand near the Byron generating station. 


\subsubsection{Quad Cities NPP, Moline, IL}

The total potential hydrogen demand within 100 miles of the Quad Cities generating station currently is $210 \mathrm{MT} /$ day. The CVR Partners ammonia production facility, 73 miles driving distance from the NPP, has a potential hydrogen demand of $155 \mathrm{MT} /$ day, and three steel producers within 50 miles driving distance have a total potential hydrogen demand of $6 \mathrm{MT} /$ day if they adapt DRI. Additionally, $25 \mathrm{NG}$ generators together have a potential hydrogen demand totaling $44 \mathrm{MT} /$ day. One notable potential hydrogen use in NG generators is the Nelson Energy Center, with a potential demand of $33 \mathrm{MT} / \mathrm{day}$ (see Table 8 and Figure 28).

The cumulative future potential hydrogen demand within 100 miles of the Quad Cities Generating Station is $2100 \mathrm{MT} /$ day, the majority of which for production of synfuels at ethanol plants. The synfuel production near ethanol plants accounts for the majority of this demand. Four ethanol facilities would create more than half that potential demand. Marquis Energy in Hennepin, with a potential hydrogen demand of 350 MT/day, Adm Cedar Rapids Dry Mill, with a potential demand of 330 MT/day, ADM Cedar Rapids Wet Mill, with potential demand of 250 MT/day, and ADM Clinton ( only 16 miles from the Quad Cities location), with a potential hydrogen demand of $250 \mathrm{MT} /$ day. The FCEVs will add less than 1 MT/day to the potential future hydrogen demand (see Figure 29). 


\begin{tabular}{|c|c|c|c|c|}
\hline \multirow[b]{2}{*}{ Name } & \multirow[b]{2}{*}{ Demand Type } & \multicolumn{2}{|c|}{$\begin{array}{l}\text { Potential } \mathrm{H} 2 \\
\text { Demand, kilotonnes }\end{array}$} & \multirow[b]{2}{*}{$\begin{array}{l}\text { Distance, } \\
\text { miles }\end{array}$} \\
\hline & & $\begin{array}{l}\text { Current } \\
(2017)\end{array}$ & $\begin{array}{l}\text { Future } \\
(2030)\end{array}$ & \\
\hline Cordova Energy: Cordova Energy Co LLC & NG Electricity Generators & 0.42 & 0.42 & 3 \\
\hline Adm Clinton Ia, Clinton & Syngas: Ethanol & 0.00 & 90.00 & 16 \\
\hline Milton L Kapp: Interstate Power and Light Co & NG Electricity Generators & 0.25 & 0.25 & 17 \\
\hline Riverside: MidAmerican Energy Co & NG Electricity Generators & 0.09 & 0.09 & 21 \\
\hline Clinton County, IA & FCEV & 0.00 & 0.00 & 24 \\
\hline Moline: MidAmerican Energy Co & NG Electricity Generators & 0.01 & 0.01 & 24 \\
\hline Scott County, IA & FCEV & 0.00 & 0.00 & 28 \\
\hline Geneseo: City of Geneseo - (IL) & NG Electricity Generators & 0.00 & 0.00 & 29 \\
\hline Whiteside County, IL & FCEV & 0.00 & 0.00 & 29 \\
\hline Rock Island County, IL & FCEV & 0.00 & 0.00 & 31 \\
\hline Carroll County, IL & FCEV & 0.00 & 0.00 & 35 \\
\hline Henry County, IL & FCEV & 0.00 & 0.00 & 39 \\
\hline Leggett and Platt Wire Rod (Formerly Sterling Steel Co. LLC) & DRI & 1.58 & 5.57 & 40 \\
\hline Davenport Water Pollution Control Plant: Davenport City of & NG Electricity Generators & 0.00 & 0.00 & 40 \\
\hline Nelson Energy Center: Invenergy Services LLC & NG Electricity Generators & 11.75 & 11.75 & 45 \\
\hline SSAB Montpelier Works & DRI & 0.82 & 2.92 & 47 \\
\hline Patriot Renewable Fuels LLC, Annawan & Syngas: Ethanol & 0.00 & 50.00 & 47 \\
\hline Jackson County, IA & FCEV & 0.00 & 0.00 & 48 \\
\hline Maquoketa 1: City of Maquoketa - (IA) & NG Electricity Generators & 0.00 & 0.00 & 52 \\
\hline Gerdau Long Steel North America - Wilton & DRI & 0.23 & 0.80 & 52 \\
\hline Lee County, IL & FCEV & 0.00 & 0.00 & 57 \\
\hline Lee Energy Facility: Lee County Generating Station & NG Electricity Generators & 0.87 & 0.87 & 58 \\
\hline Knox County, IL & FCEV & 0.00 & 0.00 & 58 \\
\hline Big River Resources Galva LLC, Galva & Syngas: Ethanol & 0.00 & 40.00 & 58 \\
\hline Mercer County, IL & FCEV & 0.00 & 0.00 & 59 \\
\hline
\end{tabular}




\begin{tabular}{|c|c|c|c|c|}
\hline Muscatine County, IA & FCEV & 0.00 & 0.00 & 61 \\
\hline Cedar County, IA & FCEV & 0.00 & 0.00 & 62 \\
\hline Adkins Energy LLC, Adkins Energy & Syngas: Ethanol & 0.00 & 20.00 & 62 \\
\hline Adkins Energy LLC: Adkins Energy LLC & NG Electricity Generators & 0.30 & 0.30 & 62 \\
\hline Tipton: City of Tipton - (IA) & NG Electricity Generators & 0.00 & 0.00 & 63 \\
\hline Jo Daviess County, IL & FCEV & 0.00 & 0.00 & 64 \\
\hline Grain Processing Corp, Muscatine & Syngas: Ethanol & 0.00 & 30.00 & 66 \\
\hline Muscatine Plant \#1: Board of Water Electric and Communications & NG Electricity Generators & 0.03 & 0.03 & 66 \\
\hline Stephenson County, IL & FCEV & 0.00 & 0.00 & 70 \\
\hline Princeton (IL): City of Princeton - (IL) & NG Electricity Generators & 0.01 & 0.01 & 71 \\
\hline Louisa: MidAmerican Energy Co & NG Electricity Generators & 0.17 & 0.17 & 72 \\
\hline Bureau County, IL & FCEV & 0.00 & 0.00 & 73 \\
\hline Cvr Partners, East Dubuque & Ammonia & 57.00 & 57.00 & 73 \\
\hline Cvr Partners, East Dubuque & Syngas: Ammonia CO2 & 0.00 & 52.87 & 73 \\
\hline Dubuque: Interstate Power and Light Co & NG Electricity Generators & 0.00 & 0.00 & 74 \\
\hline Warren County, IL & FCEV & 0.00 & 0.00 & 75 \\
\hline Stark County, IL & FCEV & 0.00 & 0.00 & 75 \\
\hline Illinois River Energy LLC, Rochelle & Syngas: Ethanol & 0.00 & 40.00 & 75 \\
\hline 1515 S Caron Road: Rochelle Municipal Utilities & NG Electricity Generators & 0.00 & 0.00 & 75 \\
\hline North Ninth Street: Rochelle Municipal Utilities & NG Electricity Generators & 0.01 & 0.01 & 75 \\
\hline South Main Street: Rochelle Municipal Utilities & NG Electricity Generators & 0.00 & 0.00 & 75 \\
\hline Ogle County, IL & FCEV & 0.00 & 0.00 & 76 \\
\hline University of Iowa Main Power Plant: University of Iowa & NG Electricity Generators & 0.73 & 0.73 & 77 \\
\hline Johnson County, IA & FCEV & 0.00 & 0.00 & 78 \\
\hline Coralville GT: MidAmerican Energy Co & NG Electricity Generators & 0.02 & 0.02 & 78 \\
\hline Dubuque County, IA & FCEV & 0.00 & 0.00 & 79 \\
\hline Oakdale Renewable Energy Plant: University of Iowa & NG Electricity Generators & 0.02 & 0.02 & 80 \\
\hline Lafayette County, WI & FCEV & 0.00 & 0.00 & 82 \\
\hline Badger State Ethanol LLC, Monroe & Syngas: Ethanol & 0.00 & 20.00 & 84 \\
\hline
\end{tabular}




\begin{tabular}{|c|c|c|c|c|}
\hline Jones County, IA & FCEV & 0.00 & 0.00 & 86 \\
\hline Cascade: Cascade Municipal Utilities & NG Electricity Generators & 0.00 & 0.00 & 87 \\
\hline Louisa County, IA & FCEV & 0.00 & 0.00 & 87 \\
\hline Hennepin Power Plant: Dynegy Midwest Generation Inc & NG Electricity Generators & 0.06 & 0.06 & 92 \\
\hline Putnam County, IL & FCEV & 0.00 & 0.00 & 92 \\
\hline Green County, WI & FCEV & 0.00 & 0.00 & 93 \\
\hline DeKalb County, IL & FCEV & 0.00 & 0.00 & 94 \\
\hline Henderson County, IL & FCEV & 0.00 & 0.00 & 94 \\
\hline Fulton County, IL & FCEV & 0.00 & 0.00 & 97 \\
\hline Archer Daniels Midland Cedar Rapids: Archer Daniels Midland Co & NG Electricity Generators & 1.99 & 1.99 & 98 \\
\hline Marquis Energy LLC, Hennepin & Syngas: Ethanol & 0.00 & 130.00 & 98 \\
\hline Adm Cedar Rapids Ia Wet Mill, Cedar Rapids Wet Mill & Syngas: Ethanol & 0.00 & 90.00 & 98 \\
\hline Peoria County, IL & FCEV & 0.00 & 0.00 & 99 \\
\hline Adm Cedar Rapids Ia Dry Mill, Cedar Rapids Dry Mill & Syngas: Ethanol & 0.00 & 120.00 & 99 \\
\hline Prairie Creek: Interstate Power and Light Co & NG Electricity Generators & 0.07 & 0.07 & 100 \\
\hline
\end{tabular}




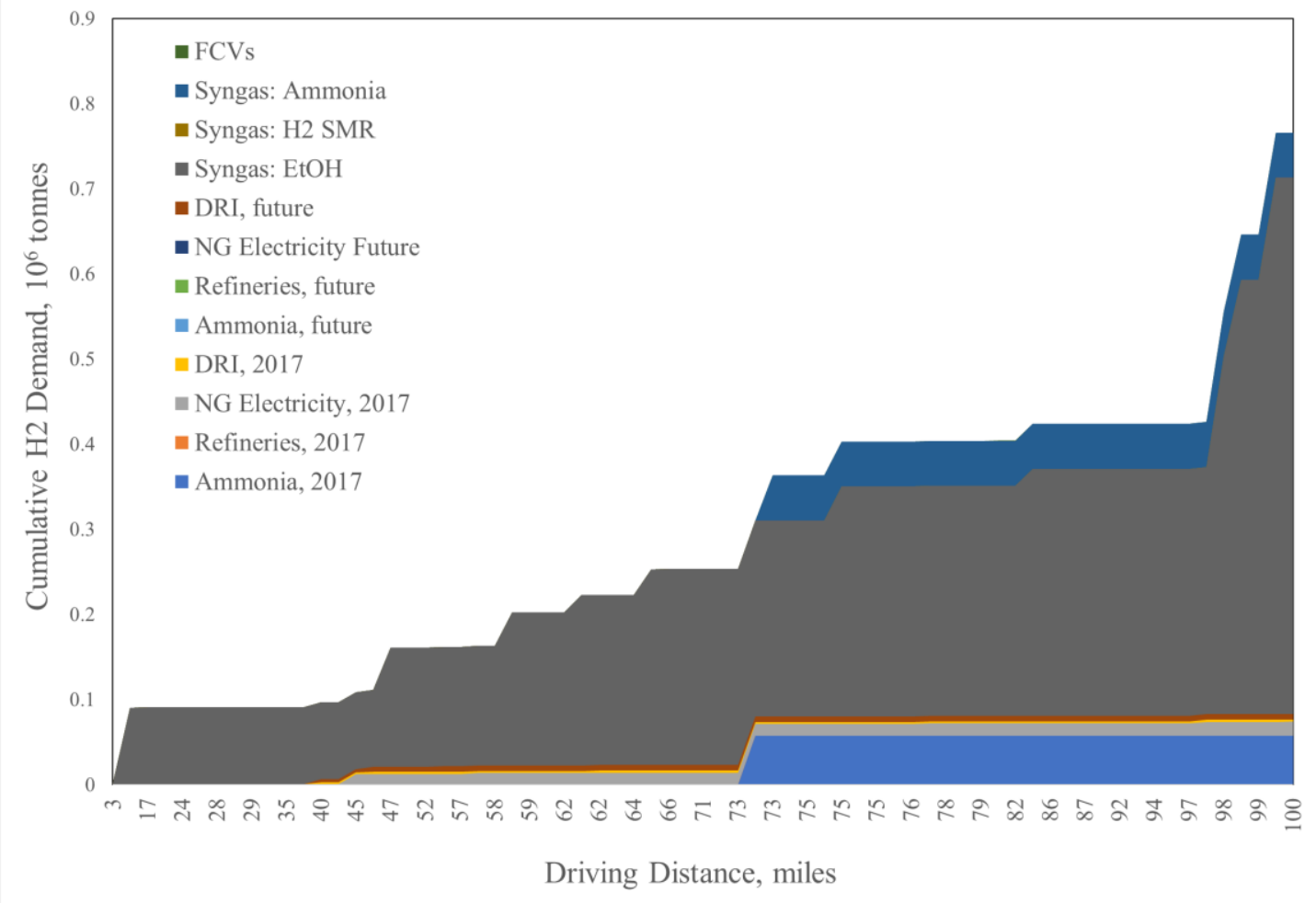

Figure 28. Cumulative potential hydrogen demand by type and distance near the Quad Cities generating station.

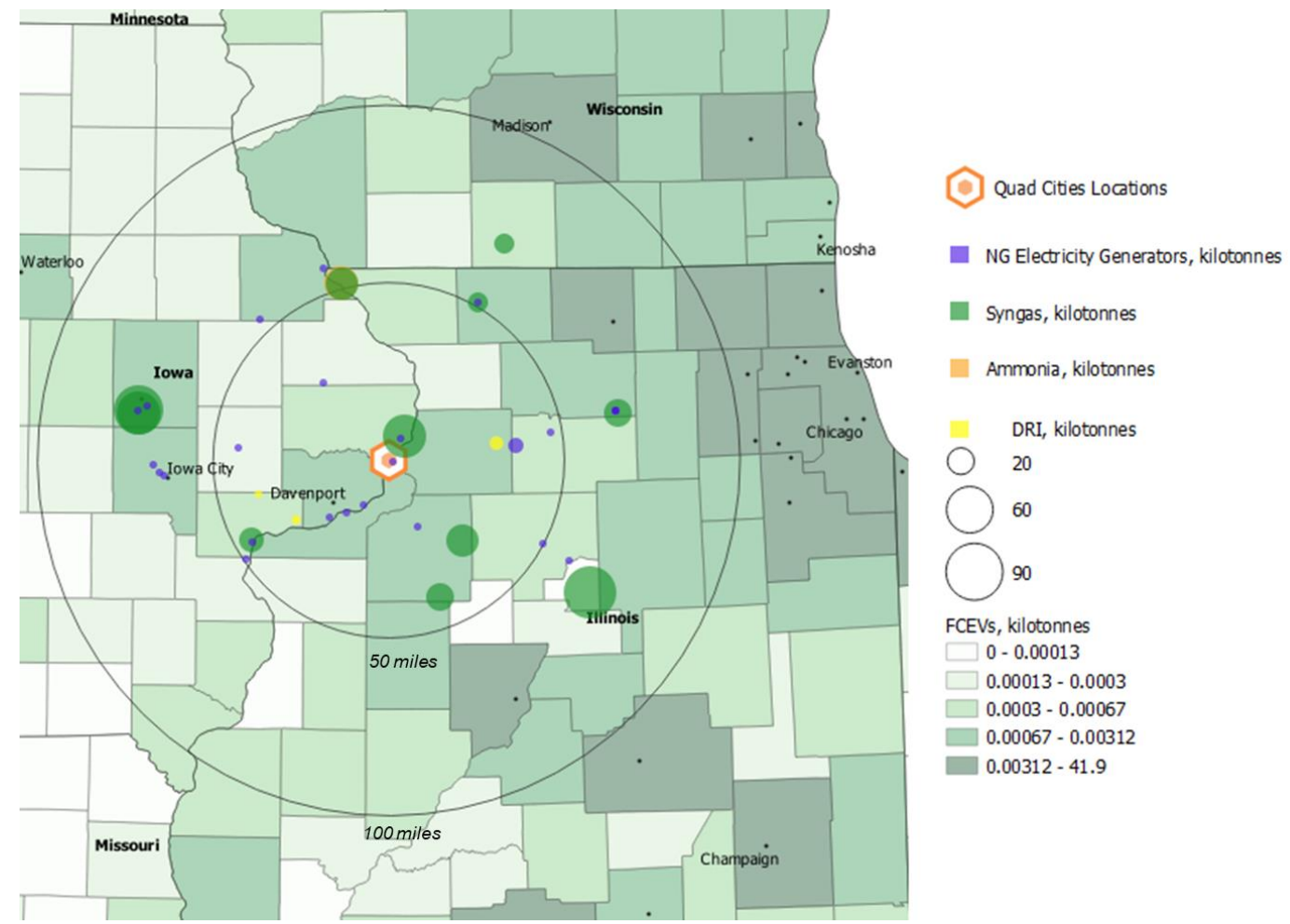

Figure 29. Future potential hydrogen demand near the Quad Cities generating station. 


\subsubsection{Dresden NPP, Joliet, IL}

Current potential hydrogen demand within 100 miles of the Dresden facility is about $1000 \mathrm{MT} / \mathrm{day}$, of which about 670 MT/day is from three refineries: ExxonMobil Corp, Joliet, PDV America Inc., Lemont, and BP PLC, Whiting. About $270 \mathrm{MT} /$ day potential hydrogen demand is from $61 \mathrm{NG}$ electricity generators. The majority of the NG electricity generators' potential hydrogen demand is from two plants. A few potential DRI facilities can be located close to the Dresden facility, with a total potential demand of $100 \mathrm{MT} /$ day (see Table 9 and Figure 30).

The potential future hydrogen demand for the Dresden facility is about $4000 \mathrm{MT} /$ day from facilities within 100 miles. Almost all of the future new demand within 100 miles is for synfuel production near the Praxair-Whiting 5 and 6 and the Marquis Energy LLC, Hennepin facilities, with potential hydrogen demand of 540 and $360 \mathrm{MT} /$ day, respectively. The total future potential demand from steel manufacturers (for DRI) is about 1400 MT/day. The U.S. Steel-Gary Works (No. 1 BOP and Q-BOP) and ArcelorMittal-Burns Harbor have the major share of this demand, with 460 and $350 \mathrm{MT} /$ day, respectively (see Figure 31). 
Table 9. Hydrogen demand within 100 miles of the Dresden generating station.

\begin{tabular}{|c|c|c|c|c|}
\hline \multirow[b]{2}{*}{ Name } & \multirow[b]{2}{*}{ Demand Type } & \multicolumn{2}{|c|}{$\begin{array}{l}\text { Potential H2 } \\
\text { Demand, kilotonnes }\end{array}$} & \multirow[b]{2}{*}{$\begin{array}{l}\text { Distance, } \\
\text { miles }\end{array}$} \\
\hline & & $\begin{array}{l}\text { Current } \\
\text { (2017) }\end{array}$ & $\begin{array}{l}\text { Future } \\
(2030)\end{array}$ & \\
\hline Grundy County, IL & FCEV & 0.00 & 0.00 & 8 \\
\hline Air Products and Chemicals, Inc. - Joliet, Il H2 Plant & Syngas: Hydrogen, SMR & 0.00 & 7.11 & 13 \\
\hline ExxonMobil Oil Joliet Refinery: ExxonMobil Oil Corp & NG Electricity Generators & 0.13 & 0.13 & 14 \\
\hline ExxonMobil Corp, Joliet & Refinery & 69.98 & 88.66 & 14 \\
\hline Joliet 29: Midwest Generations EME LLC & NG Electricity Generators & 2.41 & 2.41 & 20 \\
\hline Morris Cogeneration LLC: Morris Cogeneration LLC & NG Electricity Generators & 5.73 & 5.73 & 21 \\
\hline Kendall County Generation Facility: Dynegy Kendall Energy LLC & NG Electricity Generators & 37.86 & 37.86 & 21 \\
\hline Elwood Energy LLC: Elwood Energy LLC & NG Electricity Generators & 3.05 & 3.05 & 21 \\
\hline Joliet 9: Midwest Generations EME LLC & NG Electricity Generators & 0.41 & 0.41 & 23 \\
\hline Lincoln Generating Facility: Lincoln Generating Facility LLC & NG Electricity Generators & 0.27 & 0.27 & 27 \\
\hline Will County, IL & FCEV & 0.00 & 0.01 & 31 \\
\hline CSL Behring LLC: CSL Behring LLC & NG Electricity Generators & 0.21 & 0.21 & 32 \\
\hline Kankakee County, IL & FCEV & 0.00 & 0.00 & 33 \\
\hline Bunge Oil: CSL Behring LLC & NG Electricity Generators & 0.18 & 0.18 & 33 \\
\hline Linde Gas North America LLC, Lemont Plant & Syngas: Hydrogen, SMR & 0.00 & 46.03 & 33 \\
\hline Lemont Refinery & Syngas: Hydrogen, SMR & 0.00 & 6.71 & 36 \\
\hline Kendall County, IL & FCEV & 0.00 & 0.00 & 37 \\
\hline Nucor Steel - Kankakee Inc. & DRI & 0.56 & 1.99 & 38 \\
\hline Woodridge Greene Valley Treatment Plant: DuPage County & NG Electricity Generators & 0.00 & 0.00 & 38 \\
\hline University Park North: LSP University Park LLC & NG Electricity Generators & 3.59 & 3.59 & 39 \\
\hline University Park South: University Park Energy LLC & NG Electricity Generators & 1.40 & 1.40 & 39 \\
\hline Fox Metro Water Reclamation District: Fox Metro Water Reclamation & NG Electricity Generators & 0.00 & 0.00 & 40 \\
\hline PDV America Inc, Lemont & Refinery & 51.60 & 65.38 & 41 \\
\hline WestRock (IL): WestRock (IL) & NG Electricity Generators & 0.00 & 0.00 & 41 \\
\hline LaSalle County, IL & FCEV & 0.00 & 0.00 & 42 \\
\hline
\end{tabular}




\begin{tabular}{|c|c|c|c|c|}
\hline Argonne National Laboratory CHP: Argonne National Laboratory & NG Electricity Generators & 0.31 & 0.31 & 42 \\
\hline Panduit Tinley Park: Panduit Corp & NG Electricity Generators & 0.00 & 0.00 & 43 \\
\hline Crete Energy Venture LLC: Crete Energy Venture LLC & NG Electricity Generators & 0.34 & 0.34 & 47 \\
\hline DuPage County, IL & FCEV & 0.00 & 0.02 & 49 \\
\hline BP Naperville Cogeneration Facility: BP America Inc & NG Electricity Generators & 0.66 & 0.66 & 50 \\
\hline Livingston County, IL & FCEV & 0.00 & 0.00 & 50 \\
\hline Ingredion Incorporated: Ingredion Inc - Illinois & NG Electricity Generators & 1.68 & 1.68 & 52 \\
\hline Nalco: Nalco Co & NG Electricity Generators & 0.17 & 0.17 & 53 \\
\hline ArcelorMittal - Riverdale & DRI & 1.63 & 23.04 & 55 \\
\hline Loyola University Health Plant: Loyola University Health System & NG Electricity Generators & 1.50 & 1.50 & 55 \\
\hline Aurora: Aurora Generation LLC & NG Electricity Generators & 3.20 & 3.20 & 56 \\
\hline Iroquois County, IL & FCEV & 0.00 & 0.00 & 60 \\
\hline Finkl Steel & DRI & 0.07 & 0.23 & 60 \\
\hline Chicago West Side Energy Center: Energy Systems Group LLC & NG Electricity Generators & 0.14 & 0.14 & 60 \\
\hline Triton East and West Cogen: Triton College & NG Electricity Generators & 0.05 & 0.05 & 61 \\
\hline Calumet Energy Team LLC: IPA Operations Inc - Calumet & NG Electricity Generators & 0.19 & 0.19 & 61 \\
\hline Geneva Generation Facility: City of Geneva- (IL) & NG Electricity Generators & 0.02 & 0.02 & 61 \\
\hline Cook County, IL & FCEV & 0.00 & 0.10 & 61 \\
\hline ITT Cogen Facility: Illinois Institute-Technology & NG Electricity Generators & 0.00 & 0.00 & 61 \\
\hline University of Illinois Cogen Facility: University of Illinois & NG Electricity Generators & 0.58 & 0.58 & 62 \\
\hline Mars Snackfood US: M\&M Mars Inc & NG Electricity Generators & 0.32 & 0.32 & 62 \\
\hline DeKalb County, IL & FCEV & 0.00 & 0.00 & 63 \\
\hline Lake County, IN & FCEV & 0.00 & 0.01 & 65 \\
\hline Kane County, IL & FCEV & 0.00 & 0.01 & 65 \\
\hline Presence Saint Mary of Nazareth Hospital: Presence Health & NG Electricity Generators & 0.00 & 0.00 & 65 \\
\hline Museum of Science and Industry: Museum of Science and Industry & NG Electricity Generators & 0.00 & 0.00 & 66 \\
\hline Southeast Chicago Energy Project: Exelon Power & NG Electricity Generators & 0.27 & 0.27 & 66 \\
\hline Ford County, IL & FCEV & 0.00 & 0.00 & 66 \\
\hline ArcelorMittal - Indiana Harbor \#2 & DRI & 3.25 & 46.10 & 67 \\
\hline
\end{tabular}




\begin{tabular}{|c|c|c|c|c|}
\hline ArcelorMittal - Indiana Harbor \#3 & DRI & 4.39 & 62.22 & 67 \\
\hline ArcelorMittal - Indiana Harbor \#4 & DRI & 5.37 & 76.06 & 67 \\
\hline ArcelorMittal - Indiana Harbor Bar & DRI & 0.34 & 1.19 & 67 \\
\hline Northwest Community Hospital: Northwest Community Hospital & NG Electricity Generators & 0.08 & 0.08 & 67 \\
\hline $\begin{array}{l}\text { ArcelorMittal Indiana Harbor West: ArcelorMittal Indiana Harbor } \\
\text { West }\end{array}$ & NG Electricity Generators & 2.37 & 2.37 & 68 \\
\hline Praxair - Whiting, In 1-4 & Syngas: Hydrogen, SMR & 0.00 & 21.38 & 68 \\
\hline Praxair - Whiting, In $5 \& 6$ & Syngas: Hydrogen, SMR & 0.00 & 198.31 & 68 \\
\hline Putnam County, IL & FCEV & 0.00 & 0.00 & 68 \\
\hline Bp PLC, Whiting & Refinery & 121.28 & 153.66 & 69 \\
\hline Bp Whiting Business Unit & Syngas: Hydrogen, SMR & 0.00 & 0.00 & 69 \\
\hline Whiting Refinery: BP PLC & NG Electricity Generators & 2.09 & 2.09 & 69 \\
\hline Marquis Energy LLC, Hennepin & Syngas: Ethanol & 0.00 & 130.00 & 69 \\
\hline Whiting Clean Energy: BP Alternative Energy & NG Electricity Generators & 13.88 & 13.88 & 69 \\
\hline Gary Works: United States Steel-Gary & NG Electricity Generators & 3.79 & 3.79 & 69 \\
\hline Indiana Harbor E 5 AC Station: Northlake Energy & NG Electricity Generators & 1.23 & 1.23 & 69 \\
\hline US Steel - Gary Works (No. 1 BOP and Q-BOP) & DRI & 11.95 & 169.40 & 71 \\
\hline $\begin{array}{l}\text { Northeastern Illinois University Cogen: Northeastern Illinois } \\
\text { University }\end{array}$ & NG Electricity Generators & 0.00 & 0.00 & 71 \\
\hline Bureau County, IL & FCEV & 0.00 & 0.00 & 71 \\
\hline Elgin Energy Center LLC: Elgin Energy Center LLC & NG Electricity Generators & 1.27 & 1.27 & 72 \\
\hline Princeton (IL): City of Princeton - (IL) & NG Electricity Generators & 0.01 & 0.01 & 72 \\
\hline Hennepin Power Plant: Dynegy Midwest Generation Inc & NG Electricity Generators & 0.06 & 0.06 & 73 \\
\hline Prairies Edge Generating Facility: Prairies Edge Dairy Farms LLC & NG Electricity Generators & 0.10 & 0.10 & 73 \\
\hline Newton County, IN & FCEV & 0.00 & 0.00 & 74 \\
\hline One Earth Energy LLC, Gibson City & Syngas: Ethanol & 0.00 & 40.00 & 75 \\
\hline Gibson City Energy Center LLC: Mainline Generation LLC & NG Electricity Generators & 0.45 & 0.45 & 75 \\
\hline Hoffer Plastics: Hoffer Plastics & NG Electricity Generators & 0.01 & 0.01 & 75 \\
\hline Portside Energy: Portside Energy Corp & NG Electricity Generators & 2.82 & 2.82 & 76 \\
\hline Novolipetsk Steel (NLMK Indiana) & DRI & 0.53 & 1.87 & 76 \\
\hline
\end{tabular}




\begin{tabular}{|c|c|c|c|c|}
\hline Rocky Road Power LLC: Rocky Road Power LLC & NG Electricity Generators & 0.15 & 0.15 & 76 \\
\hline ArcelorMittal - Burns Harbor & DRI & 9.10 & 129.07 & 77 \\
\hline ArcelorMittal Burns Harbor: ArcelorMittal Burns Harbor Inc & NG Electricity Generators & 3.81 & 3.81 & 78 \\
\hline Winnetka: Village of Winnetka - (IL) & NG Electricity Generators & 0.08 & 0.08 & 78 \\
\hline R M Schahfer: Northern Indiana Pub Serv Co & NG Electricity Generators & 0.45 & 0.45 & 79 \\
\hline Bailly: Northern Indiana Pub Serv Co & NG Electricity Generators & 0.36 & 0.36 & 80 \\
\hline Jasper County, IN & FCEV & 0.00 & 0.00 & 81 \\
\hline Marshall County, IL & FCEV & 0.00 & 0.00 & 81 \\
\hline Lake Forest Hospital: Northwestern Lake Forest Hospital & NG Electricity Generators & 0.00 & 0.00 & 83 \\
\hline McLean County, IL & FCEV & 0.00 & 0.00 & 84 \\
\hline Porter County, IN & FCEV & 0.00 & 0.00 & 85 \\
\hline Rensselaer City Light Plant: City of Rensselaer - (IN) & NG Electricity Generators & 0.04 & 0.04 & 88 \\
\hline Illinois River Energy LLC, Rochelle & Syngas: Ethanol & 0.00 & 40.00 & 88 \\
\hline North Chicago Energy Center: Energy Systems Group LLC & NG Electricity Generators & 0.37 & 0.37 & 88 \\
\hline Woodford County, IL & FCEV & 0.00 & 0.00 & 89 \\
\hline 1515 S Caron Road: Rochelle Municipal Utilities & NG Electricity Generators & 0.00 & 0.00 & 89 \\
\hline Lake County, IL & FCEV & 0.00 & 0.01 & 89 \\
\hline Lee County, IL & FCEV & 0.00 & 0.00 & 90 \\
\hline McHenry County, IL & FCEV & 0.00 & 0.01 & 90 \\
\hline Lee Energy Facility: Lee County Generating Station & NG Electricity Generators & 0.87 & 0.87 & 91 \\
\hline North Ninth Street: Rochelle Municipal Utilities & NG Electricity Generators & 0.01 & 0.01 & 91 \\
\hline South Main Street: Rochelle Municipal Utilities & NG Electricity Generators & 0.00 & 0.00 & 91 \\
\hline Michigan City: Northern Indiana Pub Serv Co & NG Electricity Generators & 0.13 & 0.13 & 92 \\
\hline Iroquois Bio-Energy Co LLC, Rensselaer & Syngas: Ethanol & 0.00 & 20.00 & 93 \\
\hline Patriot Renewable Fuels LLC, Annawan & Syngas: Ethanol & 0.00 & 50.00 & 95 \\
\hline Waukegan: Midwest Generations EME LLC & NG Electricity Generators & 0.18 & 0.18 & 95 \\
\hline Benton County, IN & FCEV & 0.00 & 0.00 & 95 \\
\hline LaPorte County, IN & FCEV & 0.00 & 0.00 & 95 \\
\hline Champaign County, IL & FCEV & 0.00 & 0.00 & 97 \\
\hline
\end{tabular}


Charter Dura-Bar: Wells Manufacturing Co

Starke County, IN
0.07 FCEV
0.07

0.00 


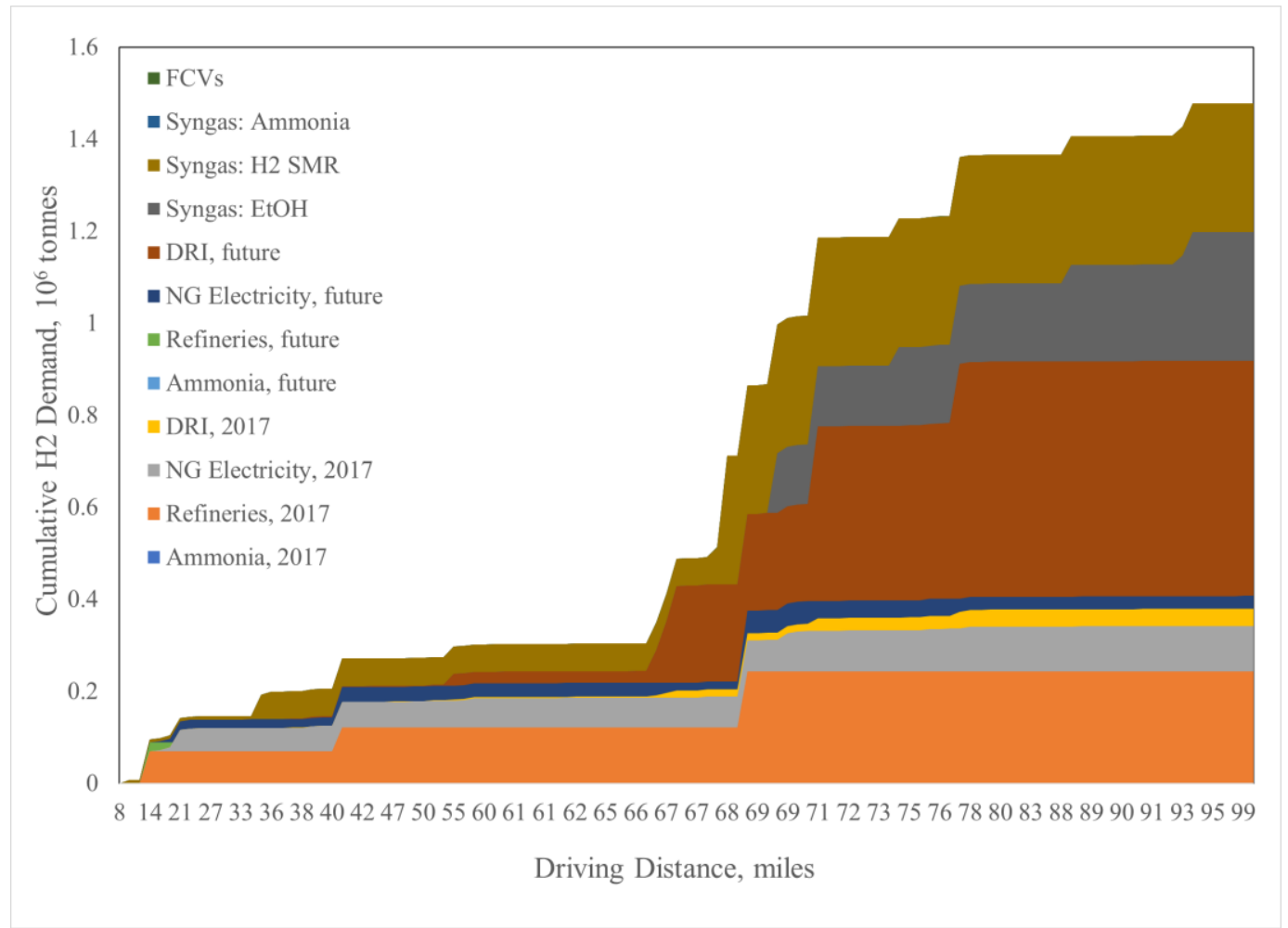

Figure 30. Cumulative potential hydrogen demand by type and distance near the Dresden generating station.

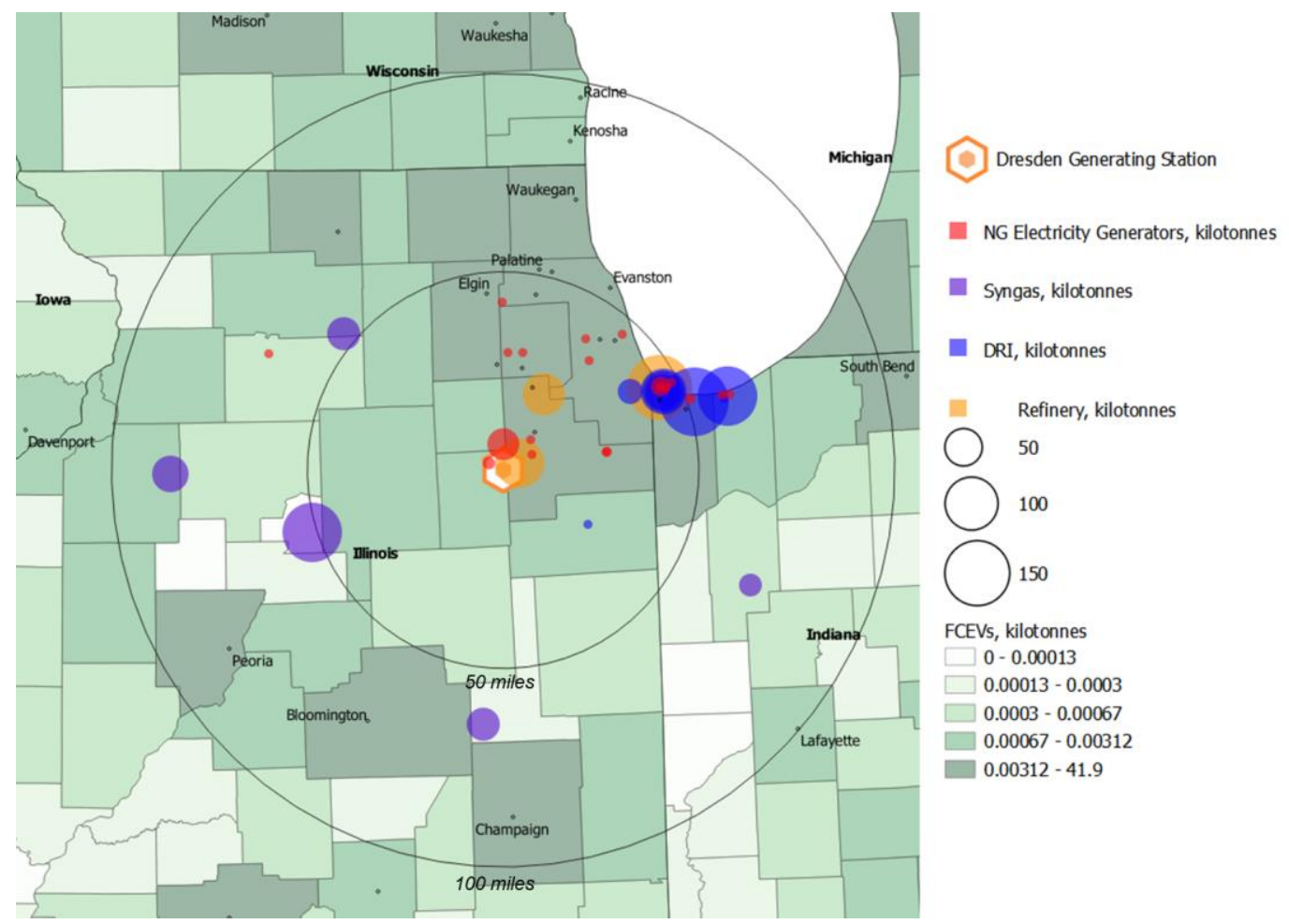

Figure 31. Future potential hydrogen demand near the Dresden generating station. 


\subsection{Minnesota Region}

Xcel Energy corporation operates two NPPs in Minnesota, the Monticello and Prairie Island NPPs, with a total electrical output of $1.1 \mathrm{GW}^{89}$, providing opportunities for producing near zero-carbon hydrogen and other nonelectric products for various potential markets. These plants are eligible for capacity payments through the capacity market. The 2019-2020 Planning Resource Auction results from April 19 suggest that Minnesota resources received \$24.30/MW-day for eligible capacity ${ }^{4}$. The potential cumulative current and future hydrogen demands out to 2030 in the regions surrounding Xcel NPPs are here examined and evaluated.

\subsubsection{Prairie Island NPP, Red Wing, MN}

The Xcel Energy Prairie Island NPP is a 1,100 MW facility located about 40 miles southeast of Minneapolis-St. Paul in Red Wing, Minnesota (see Table 10). Figure 32 shows the cumulative potential hydrogen demand within 100 miles of the Prairie Island Generating Station. Current hydrogen demand near the Prairie Island generating station is predominantly from the Western Refining and Koch Industries refineries, located in Saint Paul, Minnesota, within 30 miles of the NPP. The combined hydrogen demand from these two refineries is up to $300 \mathrm{MT} / \mathrm{day}$. The rest of the potential near-term demand, $82 \mathrm{MT} / \mathrm{day}$, is associated with the co-combustion of hydrogen with NG in 38 gas electricity generators located within 100 miles driving distance from Prairie Island generating station.

The future potential hydrogen demand for the Prairie Island Generating Station is about 1400 MT/day, from potential markets within 100 miles of the NPP (see Figure 33). The majority of the future potential hydrogen demand is from four refineries, two of which, Western Refining and Koch Industries, have a combined demand of $400 \mathrm{MT} /$ day for hydrogen for the refining process, while the other two, Flint Hills Resources Pine Bend Refinery and St. Paul Park Refining Company, provide highconcentration $\mathrm{CO}_{2}$ with an opportunity to produce synfuels, requiring up to $460 \mathrm{MT} /$ day of hydrogen. Additionally, five ethanol plants-Al-Corn Clean Fuel at Claremont, Guardian Energy at Janesville, Pro Corn at Preston, Big River Resources in Boyceville, and Heartland Corn Products in Winthrop-all located within 100 miles of the Prairie Island generating station, can produce synfuels from high-purity $\mathrm{CO}_{2}$ requiring hydrogen at $400 \mathrm{MT} /$ day. 


\begin{tabular}{|c|c|c|c|c|}
\hline \multirow[b]{2}{*}{ Name } & \multirow[b]{2}{*}{ Demand Type } & \multicolumn{2}{|c|}{$\begin{array}{l}\text { Potential H2 } \\
\text { Demand, kilotonnes }\end{array}$} & \multirow[b]{2}{*}{$\begin{array}{l}\text { Distance, } \\
\text { miles }\end{array}$} \\
\hline & & $\begin{array}{l}\text { Current } \\
(2017)\end{array}$ & $\begin{array}{l}\text { Future } \\
(2030)\end{array}$ & \\
\hline Red Wing: Northern States Power Co - Minnesota & NG Electricity Generators & 0.02 & 0.02 & 13 \\
\hline Goodhue County, MN & FCEV & - & 0.00 & 17 \\
\hline Cannon Falls Energy Center: Invenergy Services LLC & NG Electricity Generators & 0.35 & 0.35 & 20 \\
\hline LSP-Cottage Grove LP: Cottage Grove Operating Services LLC & NG Electricity Generators & 1.65 & 1.65 & 23 \\
\hline Inver Hills: Northern States Power Co - Minnesota & NG Electricity Generators & 0.09 & 0.09 & 26 \\
\hline Flint Hills Resources Pine Bend Refinery & Syngas: Hydrogen, SMR & - & 158.12 & 27 \\
\hline Western Refining Inc., Saint Paul & Refinery & 28.90 & 36.61 & 27 \\
\hline Koch Industries Inc, Saint Paul & Refinery & 85.06 & 107.76 & 27 \\
\hline St. Paul Park Refining Company, LLC & Syngas: Hydrogen, SMR & - & 15.13 & 27 \\
\hline Gerdau Long Steel North America - St. Paul & DRI & 0.40 & 1.42 & 30 \\
\hline Pierce County, WI & FCEV & - & 0.00 & 32 \\
\hline Dakota County, MN & FCEV & - & 0.01 & 33 \\
\hline St Paul Cogeneration: St Paul Cogeneration LLC & NG Electricity Generators & 0.38 & 0.38 & 38 \\
\hline High Bridge: Northern States Power Co - Minnesota & NG Electricity Generators & 10.19 & 10.19 & 39 \\
\hline Washington County, MN & FCEV & - & 0.00 & 40 \\
\hline Allen S King: Northern States Power Co - Minnesota & NG Electricity Generators & 0.04 & 0.04 & 40 \\
\hline Ramsey County, MN & FCEV & - & 0.01 & 40 \\
\hline Wabasha County, MN & FCEV & - & 0.00 & 40 \\
\hline Rice County, MN & FCEV & - & 0.00 & 41 \\
\hline Univ Minnesota CHP Plant: Veolia Energy & NG Electricity Generators & 0.83 & 0.83 & 45 \\
\hline Southeast Steam Plant: Veolia Energy & NG Electricity Generators & 0.38 & 0.38 & 46 \\
\hline St. Croix County, WI & FCEV & - & 0.00 & 48 \\
\hline Scott County, MN & FCEV & - & 0.00 & 48 \\
\hline Faribault Energy Park: Minnesota Municipal Power Agny & NG Electricity Generators & 3.41 & 3.41 & 48 \\
\hline Covanta Hennepin Energy: Covanta Energy Co & NG Electricity Generators & 0.03 & 0.03 & 49 \\
\hline
\end{tabular}




\begin{tabular}{|c|c|c|c|c|}
\hline Saint Marys Hospital Power Plant: St Mary's Hospital & NG Electricity Generators & 0.68 & 0.68 & 50 \\
\hline New Prague: New Prague Utilities Comm & NG Electricity Generators & 0.01 & 0.01 & 51 \\
\hline Hennepin County, MN & FCEV & - & 0.02 & 52 \\
\hline Water Reclamation Plant: City of Rochester & NG Electricity Generators & 0.00 & 0.00 & 52 \\
\hline Cascade Creek: Rochester Public Utilities & NG Electricity Generators & 0.21 & 0.21 & 53 \\
\hline Dodge County, MN & FCEV & - & 0.00 & 53 \\
\hline Riverside (MN): Northern States Power Co - Minnesota & NG Electricity Generators & 8.48 & 8.48 & 53 \\
\hline Olmsted County, MN & FCEV & - & 0.00 & 54 \\
\hline Franklin Heating Station: Franklin Heating Station & NG Electricity Generators & 0.86 & 0.86 & 55 \\
\hline Pepin County, WI & FCEV & - & 0.00 & 55 \\
\hline Blue Lake: Northern States Power Co - Minnesota & NG Electricity Generators & 0.65 & 0.65 & 56 \\
\hline Olmsted Waste Energy: Olmsted County Public Works & NG Electricity Generators & 0.01 & 0.01 & 57 \\
\hline Shakopee Energy Park: Minnesota Municipal Power Agny & NG Electricity Generators & 0.06 & 0.06 & 58 \\
\hline Al-Corn Clean Fuel, Claremont & Syngas: Ethanol & - & 20.00 & 59 \\
\hline Anoka County, MN & FCEV & - & 0.00 & 59 \\
\hline Koda Biomass Plant: Koda Energy LLC & NG Electricity Generators & 0.16 & 0.16 & 63 \\
\hline Minnesota River: Minnesota Municipal Power Agny & NG Electricity Generators & 0.00 & 0.00 & 63 \\
\hline Buffalo County, WI & FCEV & - & 0.00 & 64 \\
\hline Steele County, MN & FCEV & - & 0.00 & 67 \\
\hline Carver County, MN & FCEV & - & 0.00 & 68 \\
\hline Le Sueur County, MN & FCEV & - & 0.00 & 69 \\
\hline Owatonna: City of Owatonna - (MN) & NG Electricity Generators & 0.01 & 0.01 & 69 \\
\hline Big River Resources Boyceville LLC, Boyceville & Syngas: Ethanol & - & 20.00 & 73 \\
\hline Elk River: Great River Energy & NG Electricity Generators & 0.24 & 0.24 & 74 \\
\hline Dunn County, WI & FCEV & - & 0.00 & 74 \\
\hline Winona County, MN & FCEV & - & 0.00 & 75 \\
\hline Chisago County, MN & FCEV & - & 0.00 & 76 \\
\hline Polk County, WI & FCEV & - & 0.00 & 77 \\
\hline Pleasant Valley (MN): Great River Energy & NG Electricity Generators & 0.42 & 0.42 & 78 \\
\hline
\end{tabular}




\begin{tabular}{|c|c|c|c|c|}
\hline Waseca County, MN & FCEV & - & 0.00 & 78 \\
\hline Janesville: City of Janesville - (MN) & NG Electricity Generators & 0.00 & 0.00 & 80 \\
\hline Spring Valley: Spring Valley Pub Utils Comm & NG Electricity Generators & 0.00 & 0.00 & 80 \\
\hline Guardian Energy LLC, Janesville & Syngas: Ethanol & - & 60.00 & 81 \\
\hline Arcadia Electric: City of Arcadia - (WI) & NG Electricity Generators & 0.00 & 0.00 & 83 \\
\hline Eau Claire County, WI & FCEV & - & 0.00 & 84 \\
\hline Sibley County, MN & FCEV & - & 0.00 & 85 \\
\hline Isanti County, MN & FCEV & - & 0.00 & 85 \\
\hline Wright County, MN & FCEV & - & 0.00 & 86 \\
\hline Cambridge CT: Great River Energy & NG Electricity Generators & 0.20 & 0.20 & 86 \\
\hline Elk Mound: Dairyland Power Coop & NG Electricity Generators & 0.14 & 0.14 & 87 \\
\hline Sherburne County, MN & FCEV & - & 0.00 & 87 \\
\hline Nicollet County, MN & FCEV & - & 0.00 & 88 \\
\hline Fillmore County, MN & FCEV & - & 0.00 & 89 \\
\hline Wheaton: Northern States Power Co - Minnesota & NG Electricity Generators & 0.80 & 0.80 & 90 \\
\hline Preston (MN): Preston Public Utilities Comm & NG Electricity Generators & 0.00 & 0.00 & 90 \\
\hline Heartland Corn Products, Winthrop & Syngas: Ethanol & - & 30.00 & 91 \\
\hline Mower County, MN & FCEV & - & 0.00 & 91 \\
\hline Glencoe: Glencoe Light and Power Comm & NG Electricity Generators & 0.00 & 0.00 & 91 \\
\hline Wilmarth: Northern States Power Co - Minnesota & NG Electricity Generators & 0.02 & 0.02 & 94 \\
\hline Mankato Energy Center: Southern Power Co & NG Electricity Generators & 3.80 & 3.80 & 94 \\
\hline Pro Corn LLC, Preston & Syngas: Ethanol & - & 20.00 & 94 \\
\hline Blue Earth County, MN & FCEV & - & 0.00 & 96 \\
\hline Trempealeau County, WI & FCEV & - & 0.00 & 96 \\
\hline Cumberland (WI): City of Cumberland - (WI) & NG Electricity Generators & 0.00 & 0.00 & 98 \\
\hline Hutchinson Plant \#2: Hutchinson Utilities Comm & NG Electricity Generators & 0.14 & 0.14 & 99 \\
\hline Hutchinson Plant \#1: Hutchinson Utilities Comm & NG Electricity Generators & 0.06 & 0.06 & 100 \\
\hline Freeborn County, MN & FCEV & - & 0.00 & 100 \\
\hline
\end{tabular}




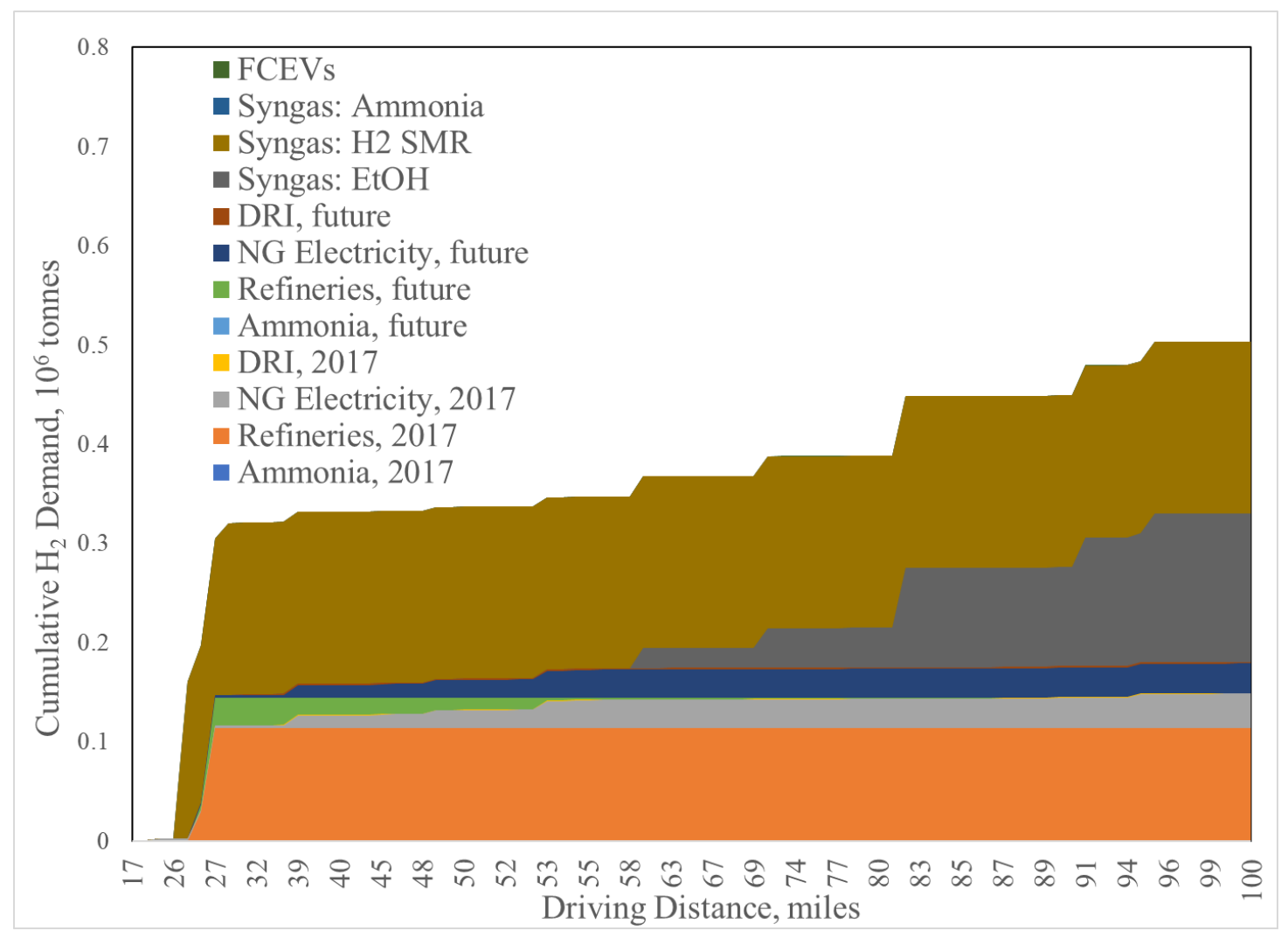

Figure 32 Cumulative potential hydrogen demand by type and distance near the Prairie Island power plant.

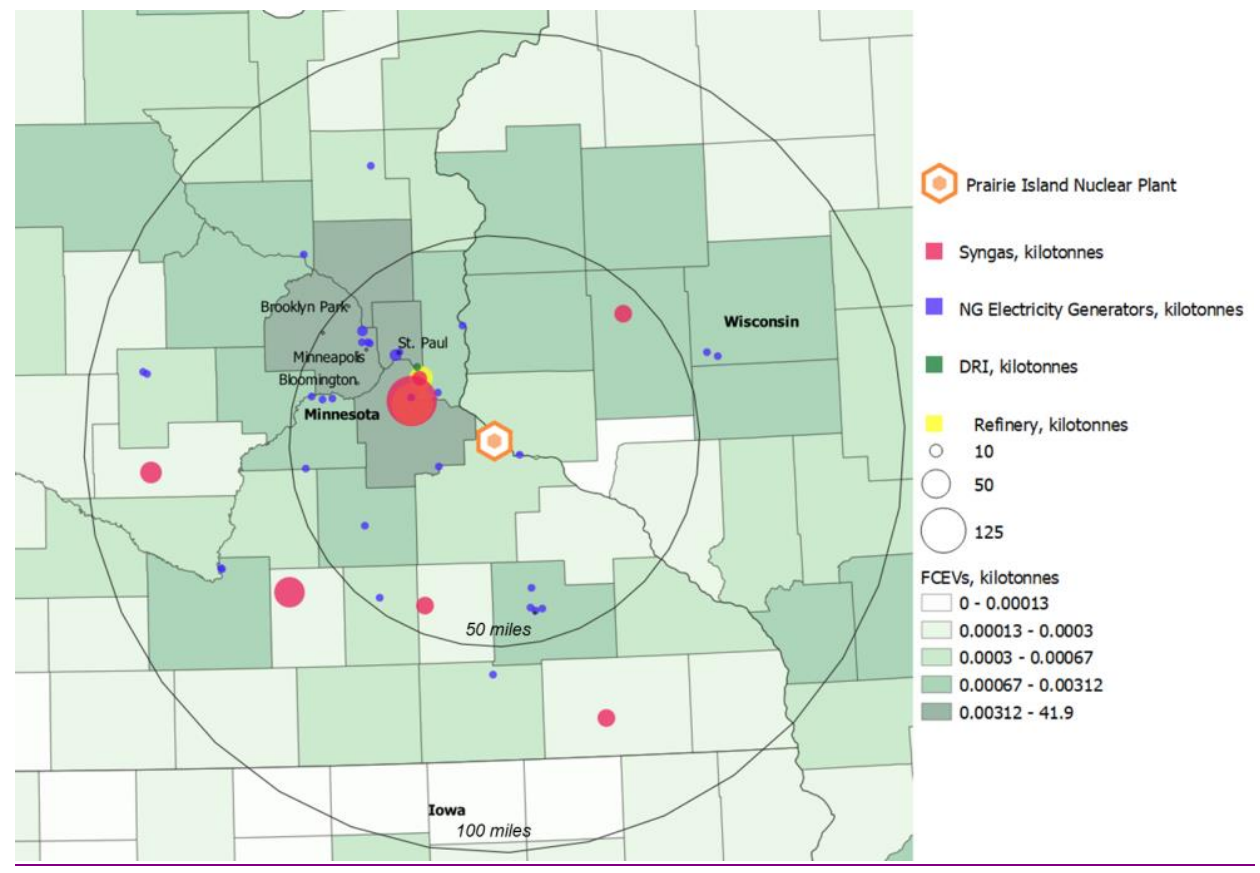

Figure 33 Future potential hydrogen demand near the Prairie Island power plant. 


\subsubsection{Monticello NPP, Monticello, MN}

The Xcel Energy Monticello NPP is a 647 MW facility located along the Mississippi river, northwest of Minneapolis-St. Paul in Monticello, Minnesota (see Table 11). Figure 34 shows the cumulative potential hydrogen demand within 100 miles of the Monticello NPP.

Current and near-term hydrogen demand near the Monticello facility depends mainly on the cocombustion of hydrogen with NG for electricity generation, and two refineries which add to this demand. The cumulative near-term potential hydrogen demand for this location is $400 \mathrm{MT} / \mathrm{day}$. About $27 \mathrm{NG}$ electricity generators located within 100 miles of this facility, have a combined potential hydrogen demand of 85 MT/day. Two refineries, Western Refining and Koch Industries, both near Saint Paul, have an estimated hydrogen demand of $310 \mathrm{MT} /$ day.

Future hydrogen demand near Monticello's location would be vastly for synfuels production, petroleum refineries, and for co-combustion of hydrogen with NG. Synfuel-producing facilities within 100 miles would have a combined future potential demand of $640 \mathrm{MT} /$ day. More than half of this would be associated with $\mathrm{CO}_{2}$ from one facility, the Flint Hills Resources Pine Bend Refinery. The refineries increase the potential demand for hydrogen to a total of about $400 \mathrm{MT} /$ day. The cumulative future hydrogen potential demand for Monticello power plant would be about 1125 MT/day within 100 miles (see Figure 35). 


\begin{tabular}{|c|c|c|c|c|}
\hline \multirow[b]{2}{*}{ Name } & \multirow[b]{2}{*}{ Demand Type } & \multicolumn{2}{|c|}{$\begin{array}{l}\text { Potential H2 Demand, } \\
\text { kilotonnes }\end{array}$} & \multirow[b]{2}{*}{$\begin{array}{l}\text { Distance, } \\
\text { miles }\end{array}$} \\
\hline & & $\begin{array}{l}\text { Current } \\
(2017)\end{array}$ & $\begin{array}{l}\text { Future } \\
(2030)\end{array}$ & \\
\hline Sherburne County, MN & FCEV & 0.00 & 0.00 & 12 \\
\hline Wright County, MN & FCEV & 0.00 & 0.00 & 13 \\
\hline Elk River: Great River Energy & NG Electricity Generators & 0.24 & 0.24 & 17 \\
\hline Granite City: Northern States Power Co - Minnesota & NG Electricity Generators & 0.00 & 0.00 & 27 \\
\hline Stearns County, MN & FCEV & 0.00 & 0.00 & 32 \\
\hline Benton County, MN & FCEV & 0.00 & 0.00 & 32 \\
\hline Anoka County, MN & FCEV & 0.00 & 0.00 & 34 \\
\hline Hennepin County, MN & FCEV & 0.00 & 0.02 & 39 \\
\hline Riverside (MN): Northern States Power Co - Minnesota & NG Electricity Generators & 8.48 & 8.48 & 39 \\
\hline Covanta Hennepin Energy: Covanta Energy Co & NG Electricity Generators & 0.03 & 0.03 & 42 \\
\hline Southeast Steam Plant: Veolia Energy & NG Electricity Generators & 0.38 & 0.38 & 43 \\
\hline Mille Lacs County, MN & FCEV & 0.00 & 0.00 & 45 \\
\hline Isanti County, MN & FCEV & 0.00 & 0.00 & 46 \\
\hline Univ Minnesota CHP Plant: Veolia Energy & NG Electricity Generators & 0.83 & 0.83 & 46 \\
\hline Meeker County, MN & FCEV & 0.00 & 0.00 & 49 \\
\hline Ramsey County, MN & FCEV & 0.00 & 0.01 & 49 \\
\hline Litchfield: Litchfield Public Utilities & NG Electricity Generators & 0.00 & 0.00 & 50 \\
\hline Blue Lake: Northern States Power Co - Minnesota & NG Electricity Generators & 0.65 & 0.65 & 52 \\
\hline Cambridge CT: Great River Energy & NG Electricity Generators & 0.20 & 0.20 & 53 \\
\hline St Paul Cogeneration: St Paul Cogeneration LLC & NG Electricity Generators & 0.38 & 0.38 & 53 \\
\hline Koda Biomass Plant: Koda Energy LLC & NG Electricity Generators & 0.16 & 0.16 & 54 \\
\hline Shakopee Energy Park: Minnesota Municipal Power Agny & NG Electricity Generators & 0.06 & 0.06 & 54 \\
\hline Minnesota River: Minnesota Municipal Power Agny & NG Electricity Generators & 0.00 & 0.00 & 54 \\
\hline McLeod County, MN & FCEV & 0.00 & 0.00 & 55 \\
\hline Glencoe: Glencoe Light and Power Comm & NG Electricity Generators & 0.00 & 0.00 & 55 \\
\hline
\end{tabular}




\begin{tabular}{|c|c|c|c|c|}
\hline High Bridge: Northern States Power Co - Minnesota & NG Electricity Generators & 10.19 & 10.19 & 55 \\
\hline Hutchinson Plant \#2: Hutchinson Utilities Comm & NG Electricity Generators & 0.14 & 0.14 & 57 \\
\hline Washington County, MN & FCEV & 0.00 & 0.00 & 57 \\
\hline Black Dog: Northern States Power Co - Minnesota & NG Electricity Generators & 3.68 & 3.68 & 57 \\
\hline Scott County, MN & FCEV & 0.00 & 0.00 & 58 \\
\hline Hutchinson Plant \#1: Hutchinson Utilities Comm & NG Electricity Generators & 0.06 & 0.06 & 58 \\
\hline Morrison County, MN & FCEV & 0.00 & 0.00 & 59 \\
\hline Gerdau Long Steel North America - St. Paul & DRI & 0.00 & 1.00 & 59 \\
\hline Carver County, MN & FCEV & 0.00 & 0.00 & 59 \\
\hline Allen S King: Northern States Power Co - Minnesota & NG Electricity Generators & 0.04 & 0.04 & 62 \\
\hline Western Refining Inc., Saint Paul & Refinery & 29.00 & 37.00 & 62 \\
\hline Mora: City of Mora - (MN) & NG Electricity Generators & 0.00 & 0.00 & 62 \\
\hline St. Paul Park Refining Company, LLC & Syngas: Hydrogen, SMR & - & 15.00 & 62 \\
\hline Kanabec County, MN & FCEV & 0.00 & 0.00 & 63 \\
\hline Bushmills Ethanol Inc, Atwater & Syngas: Ethanol & - & 30.00 & 64 \\
\hline Dakota County, MN & FCEV & 0.00 & 0.01 & 64 \\
\hline Inver Hills: Northern States Power Co - Minnesota & NG Electricity Generators & 0.09 & 0.09 & 65 \\
\hline Flint Hills Resources Pine Bend Refinery & Syngas: Hydrogen, SMR & - & 158.00 & 65 \\
\hline Koch Industries Inc, Saint Paul & Refinery & 85.00 & 108.00 & 66 \\
\hline LSP-Cottage Grove LP: Cottage Grove Operating Services LLC & NG Electricity Generators & 1.65 & 1.65 & 67 \\
\hline Sibley County, MN & FCEV & 0.00 & 0.00 & 68 \\
\hline Chisago County, MN & FCEV & 0.00 & 0.00 & 70 \\
\hline St. Croix County, WI & FCEV & 0.00 & 0.00 & 74 \\
\hline New Prague: New Prague Utilities Comm & NG Electricity Generators & 0.01 & 0.01 & 77 \\
\hline Heartland Corn Products, Winthrop & Syngas: Ethanol & - & 30.00 & 78 \\
\hline Kandiyohi County, MN & FCEV & 0.00 & 0.00 & 80 \\
\hline Willmar: Willmar Municipal Utilities & NG Electricity Generators & 0.06 & 0.06 & 82 \\
\hline Cannon Falls Energy Center: Invenergy Services LLC & NG Electricity Generators & 0.35 & 0.35 & 84 \\
\hline Pine County, MN & FCEV & 0.00 & 0.00 & 86 \\
\hline
\end{tabular}


Rice County, MN

Pierce County, WI

Polk County, WI

Faribault Energy Park: Minnesota Municipal Power Agny

Todd County, MN

Le Sueur County, MN

Pope County, MN

Douglas County, MN

Crow Wing County, MN

Renville County, MN

Red Wing: Northern States Power Co - Minnesota

$\begin{array}{llll}\text { FCEV } & 0.00 & 0.00 & 87 \\ \text { FCEV } & 0.00 & 0.00 & 88 \\ \text { FCEV } & 0.00 & 0.00 & 88 \\ \text { NG Electricity Generators } & 3.41 & 3.41 & 89 \\ \text { FCEV } & 0.00 & 0.00 & 90 \\ \text { FCEV } & 0.00 & 0.00 & 90 \\ \text { FCEV } & 0.00 & 0.00 & 92 \\ \text { FCEV } & 0.00 & 0.00 & 95 \\ \text { FCEV } & 0.00 & 0.00 & 95 \\ \text { FCEV } & 0.00 & 0.00 & 96 \\ \text { NG Electricity Generators } & 0.02 & 0.02 & 97\end{array}$




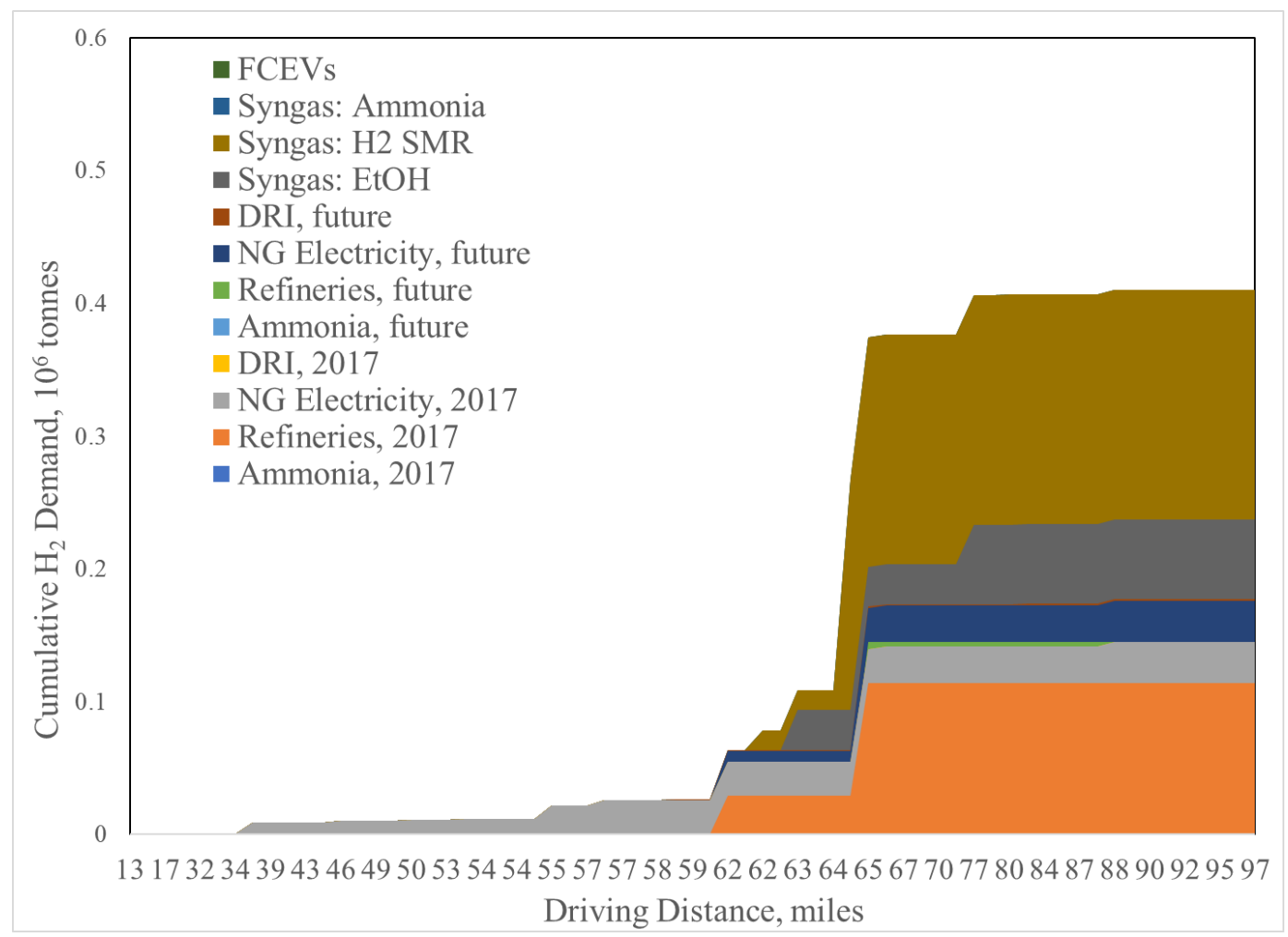

Figure 34. Cumulative potential hydrogen demand by type and distance near the Monticello power plant.

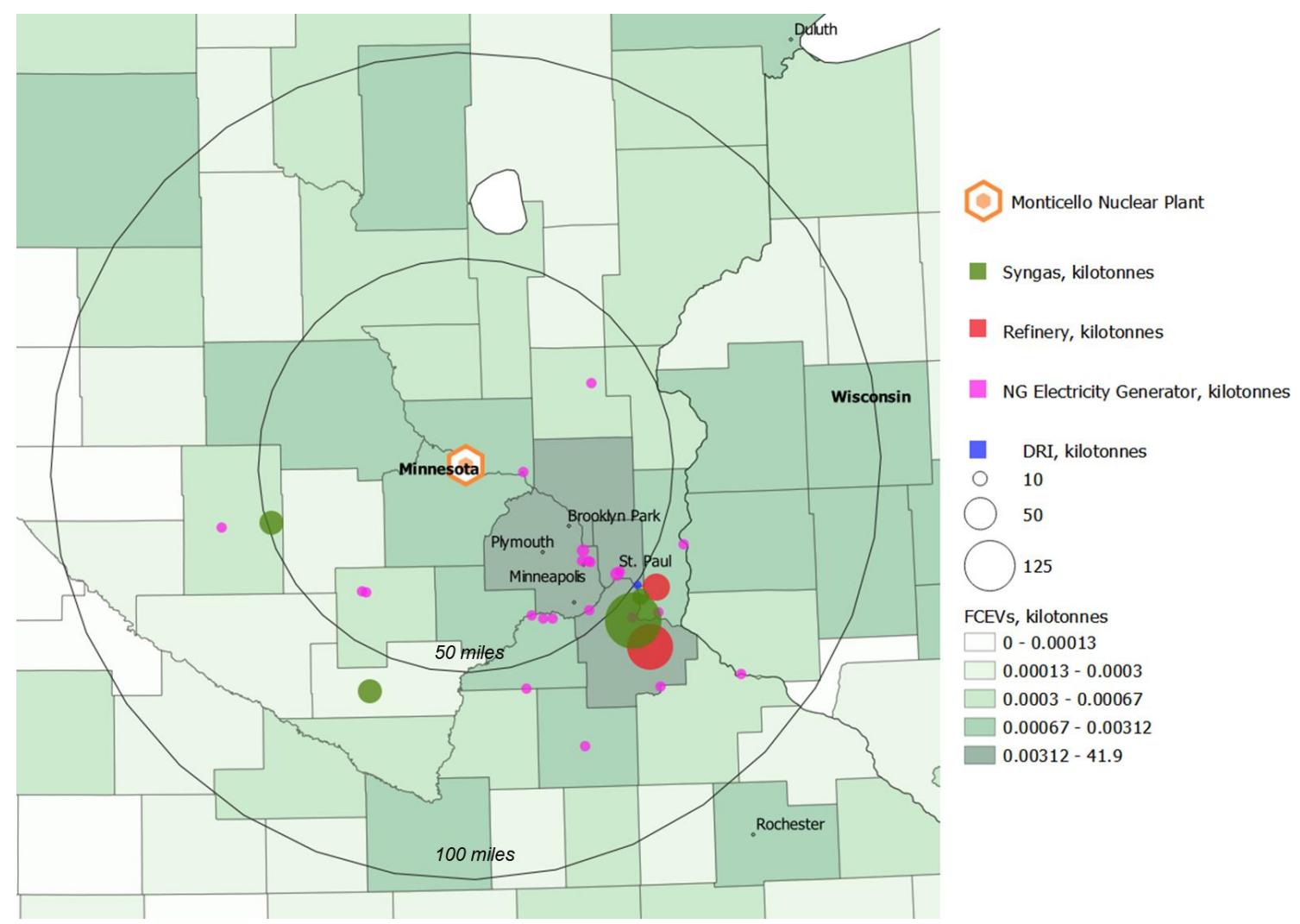

Figure 35. Future potential hydrogen demand near the Monticello power plant. 


\subsection{Ohio/Western Pennsylvania Region}

This region includes three NPPs (Davis-Besse, Perry, and Beaver Valley) with a total generating capacity of $3.9 \mathrm{GW}$ (see Figure 36). Long a manufacturing hub, this Midwestern area contains both oil refineries and an abundance of steel mills:

- Four oil refineries, totaling $\sim 400 \mathrm{MT} /$ day $\mathrm{H}_{2}$

- $\quad$ Thirty steel mills, totaling $21,500 \mathrm{MT} /$ day $\mathrm{O}_{2}$.

The Ohio and western Pennsylvania nuclear facilities are located further from farmland than the Illinois facilities; thus, they lack access to large-scale ammonia plants. There are, however, small oil refineries in Canton, Ohio, and northwestern Pennsylvania that could be served by NPP-SOEC facilities. Most notably, however, this region boasts an abundance of oxygen demand in the form of steel plants in and near Detroit, Cleveland, Canton, and Pittsburgh. The 30 steel plants within 100 miles of the three facilities represent more than $20 \%$ of total steel production capacity in the US, translating to $\sim 21,500 \mathrm{MT} /$ day $\mathrm{O}_{2}$, actually more than the NPPs can realistically provide.

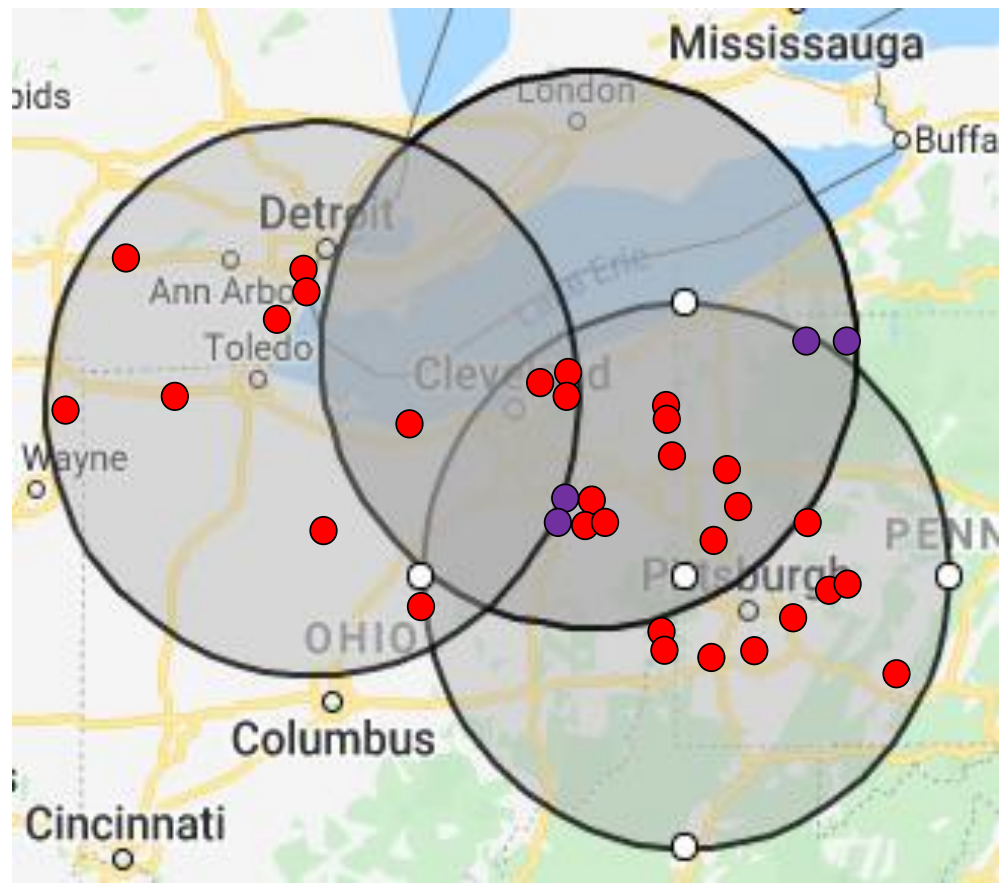

Figure 36. Location of ammonia plants (blue), oil refineries (purple), and steel mills (red) within 100 miles of the NPP facilities in Ohio and Western Pennsylvania . Shaded circles are drawn to indicate a 100 radius around each NPP.

In the electricity markets, these facilities are located within the PJM market. Although the future of capacity markets within PJM is uncertain, previous analyses have used a value of \$132/MW-day to project future capacity payments based on prior year results ${ }^{102}$.

\subsubsection{Davis-Besse NPP, Toledo OH}

First Energy's Ohio facility in Oak Harbor is considered for this analysis, with potential opportunities for making and marketing nuclear hydrogen around that plant (see Table 12). Potential cumulative hydrogen demands for the current and future 2030 scenario at increasing distances from Davis Besse facility are estimated (see Figure 37 and Figure 38). 
The Davis-Besse NPP is an 894 MW NPP located northeast of Oak Harbor, Ohio, in Ottawa County. The near-term cumulative potential hydrogen demand for the Davis-Besse facility is $580 \mathrm{MT} /$ day, mainly for metal and petroleum refining and co-combustion with NG in gas electricity generators. Three refineries, Pbf Energy in Toledo, BP Husky Refining in Toledo, and Marathon Petroleum in Detroit account for about two-thirds of the total current demand, requiring 130, 125, and $105 \mathrm{MT} / \mathrm{day}$, respectively. There are $29 \mathrm{NG}$ electricity generators with a cumulative potential demand of $160 \mathrm{MT} / \mathrm{day}$ within 100 miles of the David-Besse power plant.

The future potential demand for hydrogen within 100 miles of the Davis-Besse facility is associated with DRI for metal refining, synfuels production, and petroleum refineries. The cumulative potential demand is $2400 \mathrm{MT} /$ day for the year 2030. Majority of the future hydrogen demand is potentially for metal refining using DRI processes at $1200 \mathrm{MT} /$ day, which includes the Cliffs HBI plant in Toledo, with a future potential hydrogen demand of 440 MT/day if hydrogen is used exclusively for the DRI process. Additionally, the potential future hydrogen demand for producing synfuels using $\mathrm{CO}_{2}$ sources from Linde Gas in Toledo, and from Air Products and Chemicals in Detroit and is at 200 and $150 \mathrm{MT} / \mathrm{day}$, respectively. The potential for synfuels production from $\mathrm{CO}_{2}$ at ethanol-producing facilities adds another $270 \mathrm{MT} /$ day to the potential future hydrogen demand. 
Table 12. Hydrogen demand within 100 miles of the Davis-Besse NPP.

\begin{tabular}{|c|c|c|c|c|}
\hline Name & Demand Type & \multicolumn{2}{|c|}{$\begin{array}{l}\text { Potential H2 Demand, } \\
\text { kilotonnes }\end{array}$} & $\begin{array}{l}\text { Distance, } \\
\text { miles }\end{array}$ \\
\hline Fremont Energy Center: American Mun Power-Ohio, Inc & NG Electricity Generators & 16.51 & 16.5 & 20 \\
\hline Pbf Energy Co LLC, Toledo & Refinery & 46.93 & 59.5 & 22 \\
\hline Oregon Clean Energy Center: Oregon Clean Energy Center & NG Electricity Generators & 12.51 & 12.5 & 23 \\
\hline Sandusky County, OH & FCEV & 0.00 & 0.0 & 25 \\
\hline Bp Husky Refining LLC, Toledo & Refinery & 44.88 & 56.9 & 25 \\
\hline Cliffs HBI Plant, Toledo, $\mathrm{OH}$ & DRI & 0.00 & 160.0 & 25 \\
\hline Troy Energy LLC: Troy Energy LLC & NG Electricity Generators & 1.29 & 1.3 & 26 \\
\hline $\begin{array}{l}\text { Bay View Backup Power Facility: COT/Division of Water } \\
\text { Reclamation }\end{array}$ & NG Electricity Generators & 0.00 & 0.0 & 27 \\
\hline Bowling Green Peaking: American Mun Power-Ohio, Inc & NG Electricity Generators & 0.02 & 0.0 & 38 \\
\hline Seneca County, $\mathrm{OH}$ & FCEV & 0.00 & 0.0 & 38 \\
\hline Poet Biorefining-Fostoria LLC, Fostoria & Syngas: Ethanol & 0.00 & 30.0 & 40 \\
\hline Bowling Green Generating Station: American Mun Power-Ohio, Inc & NG Electricity Generators & 0.03 & 0.0 & 41 \\
\hline Monroe County, MI & FCEV & 0.00 & 0.0 & 44 \\
\hline Huron County, $\mathrm{OH}$ & FCEV & 0.00 & 0.0 & 47 \\
\hline Green Plains Holdings Ii, Green Plains - Riga & Syngas: Ethanol & 0.00 & 20.0 & 53 \\
\hline Wyandot County, $\mathrm{OH}$ & FCEV & 0.00 & 0.0 & 57 \\
\hline Bluescope Steel North America & DRI & 1.44 & 5.1 & 60 \\
\hline Fulton County, OH & FCEV & 0.00 & 0.0 & 63 \\
\hline
\end{tabular}




\begin{tabular}{|c|c|c|c|c|}
\hline Oberlin $(\mathrm{OH})$ : City of Oberlin - $(\mathrm{OH})$ & NG Electricity Generators & 0.00 & 0.0 & 64 \\
\hline Henry County, OH & FCEV & 0.00 & 0.0 & 66 \\
\hline Lorain County, $\mathrm{OH}$ & FCEV & 0.00 & 0.0 & 66 \\
\hline Lenawee County, MI & FCEV & 0.00 & 0.0 & 67 \\
\hline Hancock County, OH & FCEV & 0.00 & 0.0 & 67 \\
\hline Wyandotte: Wyandotte Municipal Serv Comm & NG Electricity Generators & 0.18 & 0.2 & 69 \\
\hline Marathon Petroleum Corp, Detroit & Refinery & 38.72 & 49.1 & 74 \\
\hline $\begin{array}{l}\text { Air Products and Chemicals Inc./Detroit Hydrogen Facility Marathon } \\
\text { Refinery }\end{array}$ & Syngas: Hydrogen, SMR & 0.00 & 56.9 & 75 \\
\hline Poet Biorefining-Leipsic LLC, Leipsic & Syngas: Ethanol & 0.00 & 20.0 & 75 \\
\hline AK Steel Corp. - Mansfield & DRI & 0.46 & 1.6 & 75 \\
\hline Ashland County, $\mathrm{OH}$ & FCEV & 0.00 & 0.0 & 76 \\
\hline Sauder Power Plant: Sauder Woodworking Co & NG Electricity Generators & 0.00 & 0.0 & 76 \\
\hline US Steel - Great Lakes Works & DRI & 5.20 & 73.7 & 77 \\
\hline Delray: DTE Electric Company & NG Electricity Generators & 0.26 & 0.3 & 77 \\
\hline Broshco Fabricated Products: Broshco Fabricated Products & NG Electricity Generators & 0.03 & 0.0 & 77 \\
\hline Richland County, OH & FCEV & 0.00 & 0.0 & 78 \\
\hline Richland: Richland-Stryker Generation LLC & NG Electricity Generators & 0.00 & 0.0 & 78 \\
\hline Poet Biorefining-Marion LLC, Marion & Syngas: Ethanol & 0.00 & 30.0 & 78 \\
\hline River Rouge: DTE Electric Company & NG Electricity Generators & 0.59 & 0.6 & 79 \\
\hline Wayne County, MI & FCEV & 0.00 & 0.0 & 79 \\
\hline Marion County, OH & FCEV & 0.00 & 0.0 & 79 \\
\hline Washtenaw County, MI & FCEV & 0.00 & 0.0 & 80 \\
\hline
\end{tabular}


East. Michigan Univ. Heating Plant: East. Michigan Univ. Heating Plant

Galion Generating Station: American Mun Power-Ohio, Inc

Nucor Steel - Marion Inc.

University of Michigan: University of Michigan

Warner Lambert: University of Michigan NCampus Research

Defiance County, $\mathrm{OH}$

West 41st Street: City of Cleveland - $(\mathrm{OH})$

Bryan (OH): City of Bryan - $(\mathrm{OH})$

ArcelorMittal - Cleveland East

NG Electricity Generators

NG Electricity Generators

$0.00 \quad 0.0$

80

Charter Steel

$$
\text { DRI }
$$

NG Electricity Generators

$0.02 \quad 0.0$

$0.26 \quad 0.9$

NG Electricity Generators

$2.40 \quad 2.4$

FCEY

$0.25 \quad 0.3$

NG Electricity Generators

$0.00 \quad 0.0$

NG Electricity Generators

$0.00 \quad 0.0$

$0.02 \quad 0.0$

DRI

DRI

Charter Steel

DRI

Cuyahoga County, $\mathrm{OH}$

FCEV

Putnam County, $\mathrm{OH}$

FCEV

Arcelormittal Cleveland Inc: ArcelorMittal Cleveland Inc

Cleveland Thermal: Cleveland Thermal, LLC

NG Electricity Generators

NG Electricity Generators

ArcelorMittal - Cleveland West

Williams County, $\mathrm{OH}$

DRI

Northeast (MI): DTE Electric Company

FCEV

NG Electricity Generators

FCEV

Morrow County, $\mathrm{OH}$

FCEV

Hardin County, $\mathrm{OH}$

NG Electricity Generators

$3.74 \quad 53.0$

0.43

0.42

0.00

1.5

0.00

0.0

0.0

$0.42 \quad 0.4$

$0.89 \quad 0.9$

$3.09 \quad 43.8$

$0.00 \quad 0.0$

$0.03 \quad 0.0$

$0.00 \quad 0.0$

$0.00 \quad 0.0$

FCEV

$0.09 \quad 0.1$

Medina County, $\mathrm{OH}$

Hillsdale County, MI

Collinwood: City of Cleveland - $(\mathrm{OH})$

FCEV

$0.00 \quad 0.0$

$0.00 \quad 0.0$

NG Electricity Generators

$0.00 \quad 0.0$

FCEV

$0.00 \quad 0.0$

FCEV

$0.00 \quad 0.0$

FCEV

0.00

0.00

0.0

Allen County, $\mathrm{OH}$

FCEV

100 


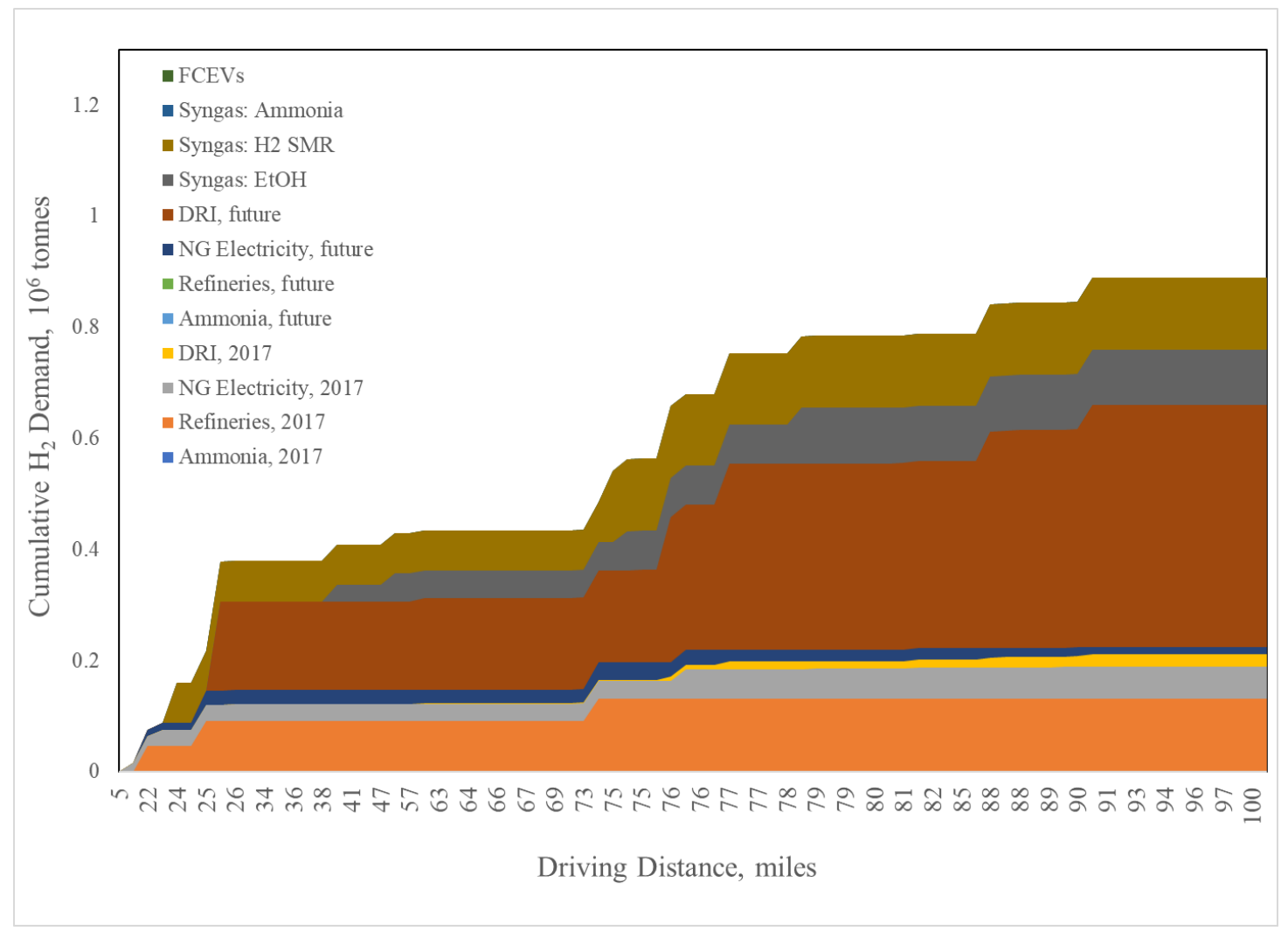

Figure 37. Cumulative potential hydrogen demand by type and distance near the Davis Besse Power Plant.

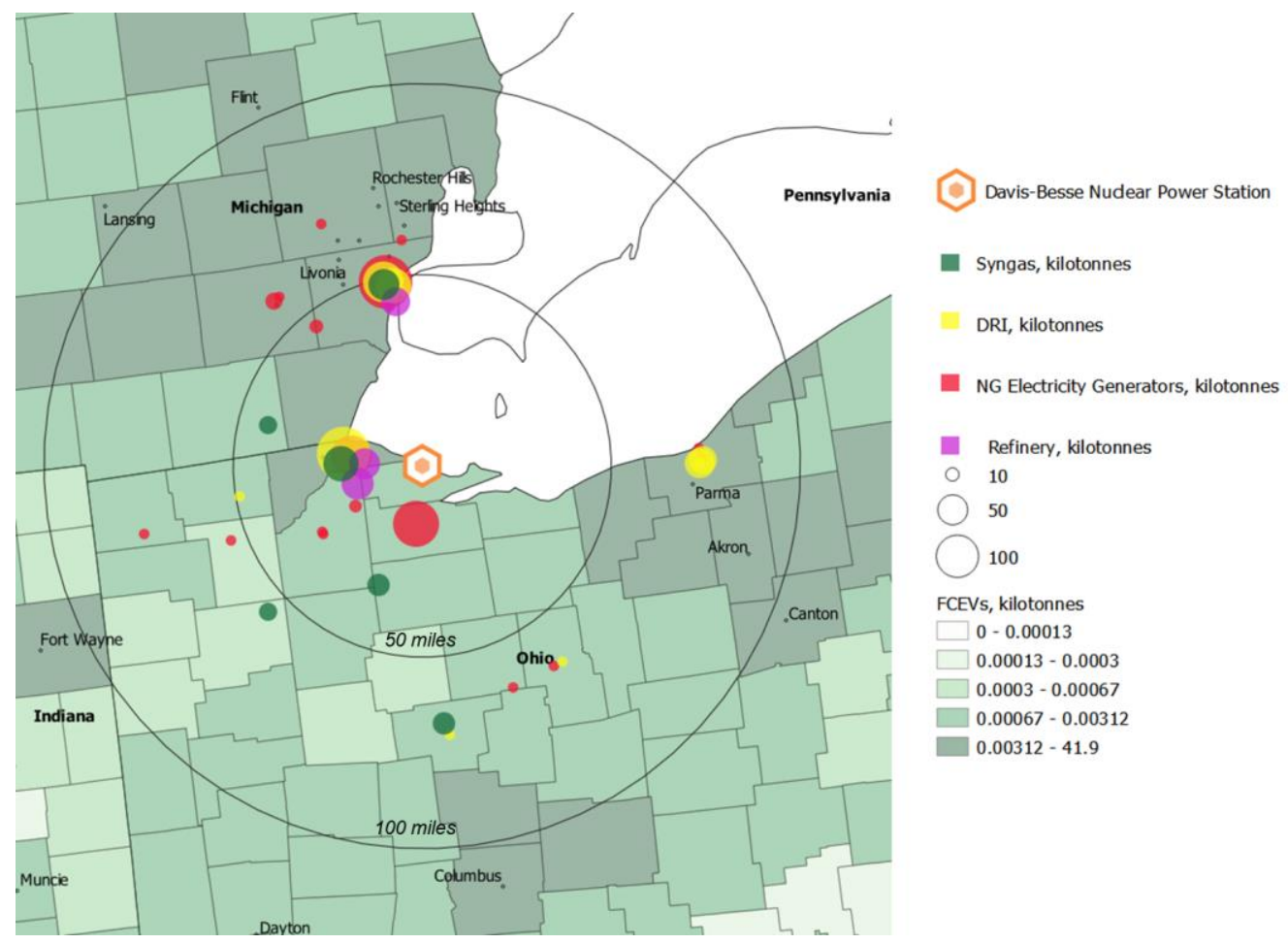

Figure 38. Future potential hydrogen demand near the Davis-Besse NPP. 


\subsection{Alabama and Georgia Region}

The Southern Company region includes NPPs in Alabama and Georgia that supply electricity to these and surrounding states. This analysis considers three Southern Company NPPs - the Farley, Hatch, and Vogtle Generating Stations - and identifies potential opportunities for making and marketing nuclear hydrogen produced by these plants.

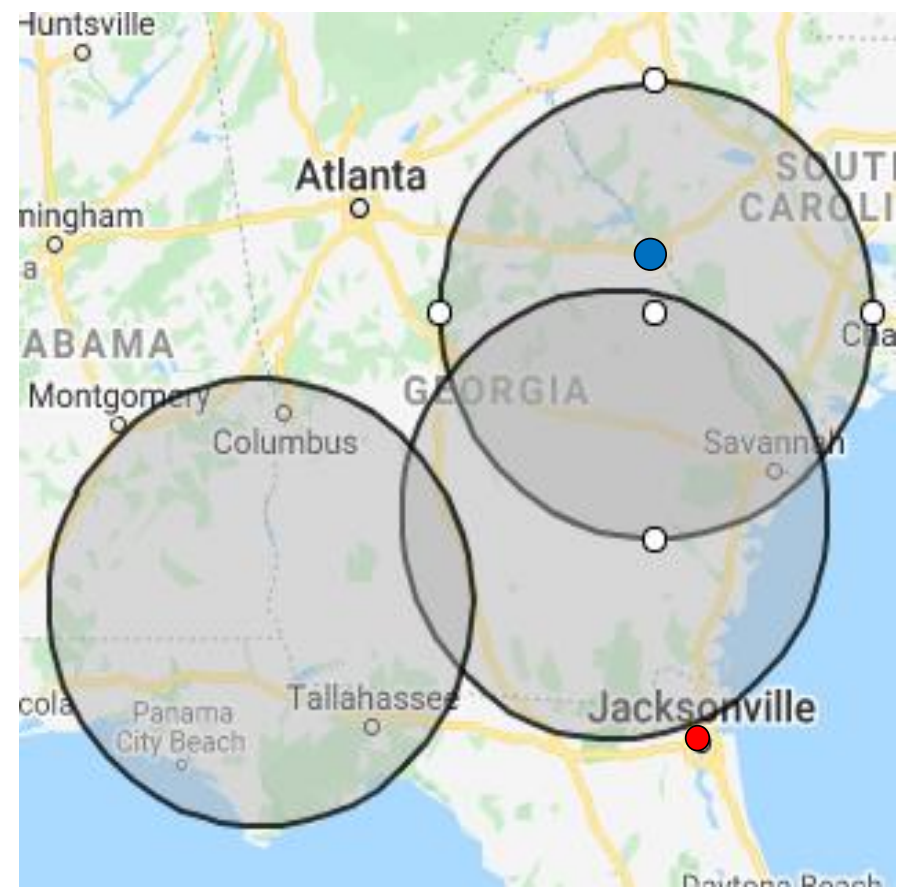

Figure 39. Location of ammonia plants (blue), oil refineries (purple), and steel mills (red) within 100 miles of the NPP facilities in Alabama and Georgia. Large filled circles are drawn to indicate a 100 radius around each NPP.

This region includes three named NPPs with $6 \mathrm{GW}$ total capacity. This area of the Southeast lacks point demand sources of $\mathrm{H}_{2}$ or $\mathrm{O}_{2}$, although there are a number of large steel mills in northern and western Alabama, outside of the 100 mile radius from the Joseph Farley facility. There is a single ammonia plant in Augusta, Georgia, which consumes nearly $500 \mathrm{MT} /$ day of hydrogen. The one steel mill in Jacksonville, Florida, consumes about $400 \mathrm{MT} /$ day $\mathrm{O}_{2}$, but extending the Alabama plant radius to 300 miles would bring the total accessible $\mathrm{O}_{2}$ demand from steel mills to almost 7,500 MT/day.

\subsubsection{Farley NPP, Dothan, AL}

The potential near-term hydrogen demand around the Joseph Farley Generating Station is almost entirely for co-combustion of hydrogen with NG (see Table 13). Eleven NG electricity generators within 100 miles of the Farley facility have a combined potential hydrogen demand of 165 MT/day. Most of the demand is associated with three facilities, the City of Tallahassee's Arvah B. Hopkins generator at 25 MT/day, the Gulf Power's Lansing Smith generator at 60 MT/day, and the PowerSouth Energy Cooperative's McWilliams generator at 63 MT/day (see Figure 40).

The total future potential hydrogen demand around the Farley NPP is $300 \mathrm{MT} / \mathrm{day}$. The $\mathrm{CO}_{2}$ from the Flint Hills' Camilla ethanol facility presents an opportunity for using nuclear hydrogen produced by Southern Company to produce synfuels that could result in a potential future hydrogen demand of 140 MT/day within 73 miles from the Farley NPP (see Figure 41). 
Table 13. Hydrogen demand within 100 miles of the Joseph Farley NPP.

\begin{tabular}{|c|c|c|c|c|}
\hline Name & Demand Type & \multicolumn{2}{|c|}{$\begin{array}{l}\text { Potential H2 Demand, } \\
\text { kilotonnes }\end{array}$} & $\begin{array}{l}\text { Distance, } \\
\text { miles }\end{array}$ \\
\hline Houston County, AL & FCEV & 0.00 & 0.00 & 19 \\
\hline Henry County, AL & FCEV & 0.00 & 0.00 & 24 \\
\hline Early County, GA & FCEV & 0.00 & 0.00 & 24 \\
\hline Jackson County, FL & FCEV & 0.00 & 0.00 & 35 \\
\hline Miller County, GA & FCEV & 0.00 & 0.00 & 36 \\
\hline Clay County, GA & FCEV & 0.00 & 0.00 & 37 \\
\hline Dale County, AL & FCEV & 0.00 & 0.00 & 42 \\
\hline Calhoun County, GA & FCEV & 0.00 & 0.00 & 43 \\
\hline Barbour County, AL & FCEV & 0.00 & 0.00 & 54 \\
\hline Coffee County, AL & FCEV & 0.00 & 0.00 & 54 \\
\hline Baker County, GA & FCEV & 0.00 & 0.00 & 55 \\
\hline Holmes County, FL & FCEV & 0.00 & 0.00 & 57 \\
\hline Washington County, FL & FCEV & 0.00 & 0.00 & 59 \\
\hline Calhoun County, FL & FCEV & 0.00 & 0.00 & 59 \\
\hline Gadsden County, FL & FCEV & 0.00 & 0.00 & 65 \\
\hline Grady County, GA & FCEV & 0.00 & 0.00 & 67 \\
\hline Mitchell County, GA & FCEV & 0.00 & 0.00 & 69 \\
\hline Liberty County, FL & FCEV & 0.00 & 0.00 & 72 \\
\hline
\end{tabular}




\begin{tabular}{|c|c|c|c|c|}
\hline Dougherty County, GA & FCEV & 0.00 & 0.00 & 73 \\
\hline Flint Hills Resources LP, Camilla & Syngas: Ethanol & - & 50.00 & 73 \\
\hline Pike County, AL & FCEV & 0.00 & 0.00 & 74 \\
\hline Mead Coated Board: Mead Coated Board Inc & NG Electricity Generators & 2.53 & 2.53 & 76 \\
\hline Albany Green Energy: Albany Green Energy, LLC & NG Electricity Generators & 0.01 & 0.01 & 76 \\
\hline Sowega Power: SOWEGA Power LLC & NG Electricity Generators & 0.33 & 0.33 & 77 \\
\hline Webster County, GA & FCEV & 0.00 & 0.00 & 79 \\
\hline Lee County, GA & FCEV & 0.00 & 0.00 & 80 \\
\hline Bay County Waste to Energy: Bay County Board-County Comm & NG Electricity Generators & 0.02 & 0.02 & 81 \\
\hline Arvah B Hopkins: City of Tallahassee - (FL) & NG Electricity Generators & 9.13 & 9.13 & 83 \\
\hline Covington County, AL & FCEV & 0.00 & 0.00 & 89 \\
\hline Leon County, FL & FCEV & 0.00 & 0.01 & 89 \\
\hline Bay County, FL & FCEV & 0.00 & 0.01 & 91 \\
\hline Worth County, GA & FCEV & 0.00 & 0.00 & 91 \\
\hline WestRock Panama City Mill: WestRock Corp-Panama City & NG Electricity Generators & 1.92 & 1.92 & 93 \\
\hline Colquitt County, GA & FCEV & 0.00 & 0.00 & 95 \\
\hline Russell County, AL & FCEV & 0.00 & 0.00 & 95 \\
\hline Crenshaw County, AL & FCEV & 0.00 & 0.00 & 96 \\
\hline McWilliams: PowerSouth Energy Cooperative & NG Electricity Generators & 22.64 & 22.64 & 97 \\
\hline Walton County, FL & FCEV & 0.00 & 0.00 & 98 \\
\hline Sumter County, GA & FCEV & 0.00 & 0.00 & 99 \\
\hline
\end{tabular}




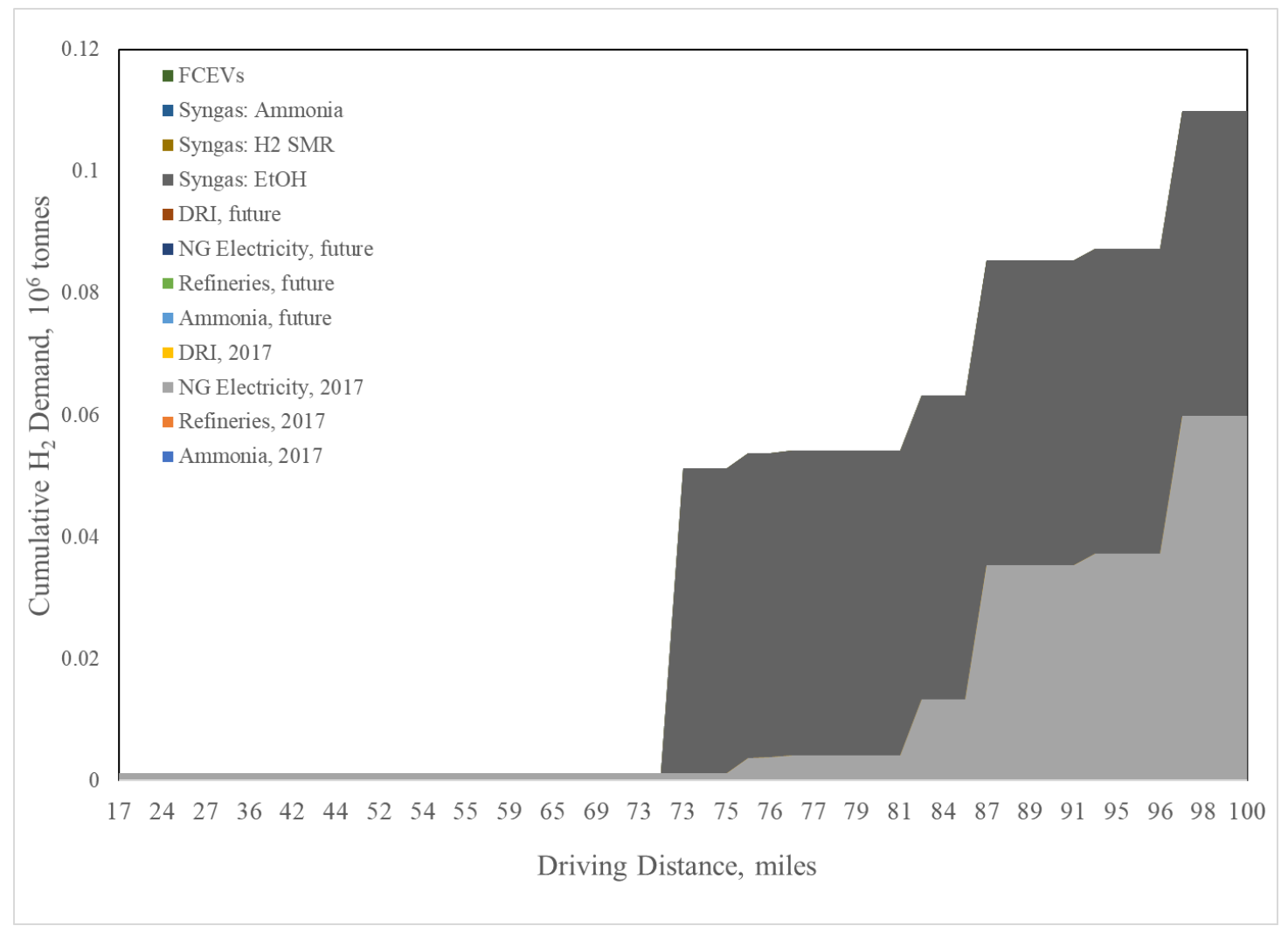

Figure 40. Cumulative potential hydrogen demand by type and distance near the Farley NPP.

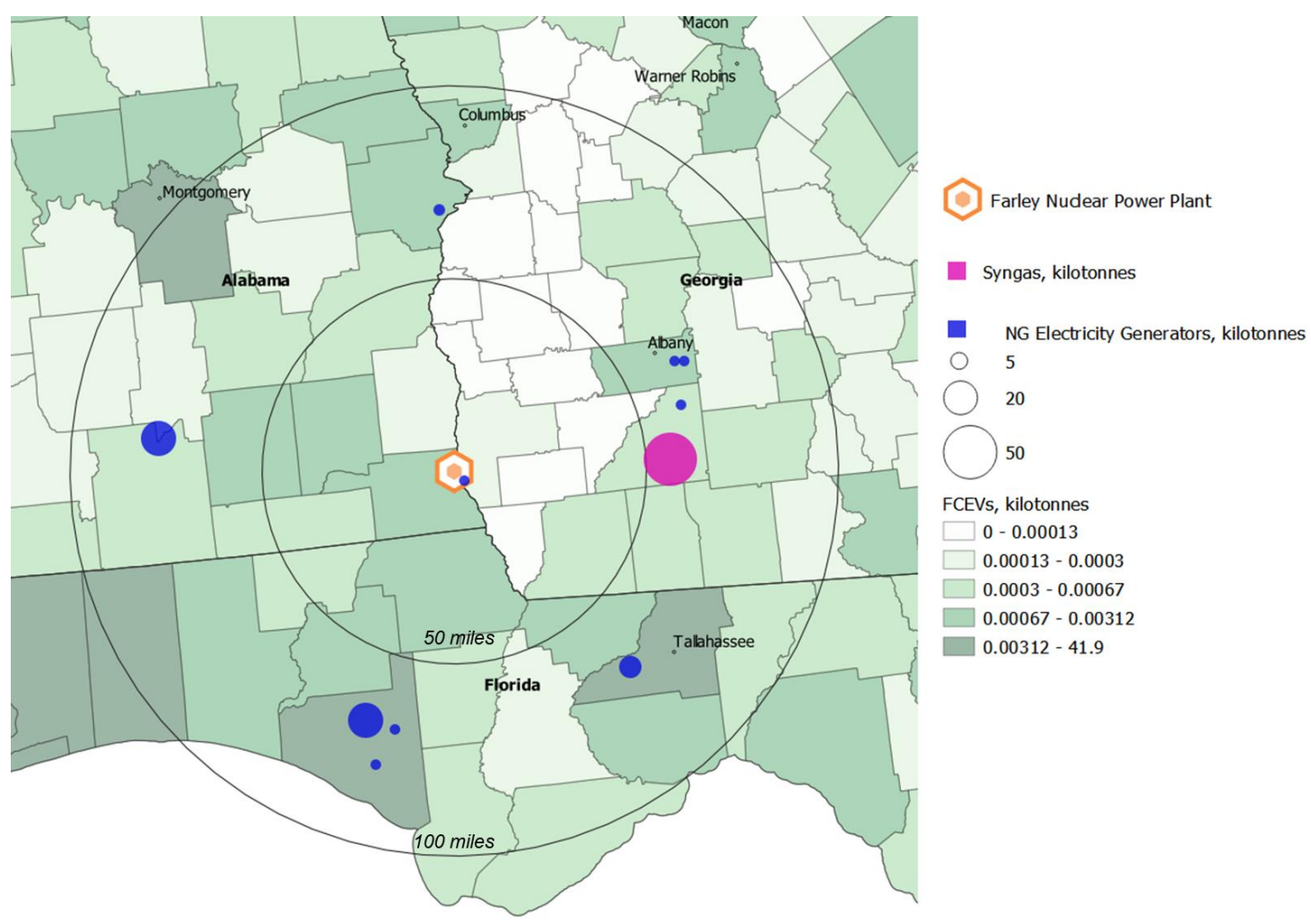

Figure 41. Future potential hydrogen demand near the Farley NPP 


\subsubsection{Hatch NPP, Vidalia, GA}

The total current near-term potential hydrogen demand within 100 miles of the Hatch generating station is $190 \mathrm{MT} /$ day, entirely for co-combustion of hydrogen with NG in $13 \mathrm{NG}$ generators (see Table 14). Two notable potential hydrogen markets associated with co-combustion of hydrogen in NG generators are the Georgia Power's McIntosh generator, at 125 MT/day, and Effingham County Power Project in Effingham, at 35 MT/day, as illustrated in Figure 42.

The additional potential future demand for the Hatch nuclear plant may come from fuel cell vehicles, which adds less than $1 \mathrm{MT} /$ day around Hatch facility (see Figure 43). 
Table 14, Hydrogen demand within 100 miles of the Hatch NPP,

\begin{tabular}{|c|c|c|c|c|}
\hline \multirow[b]{2}{*}{ Name } & \multirow[b]{2}{*}{ Demand Type } & \multicolumn{2}{|c|}{$\begin{array}{l}\text { Potential H2 Demand, } \\
\text { kilotonnes }\end{array}$} & \multirow[b]{2}{*}{$\begin{array}{l}\text { Distance, } \\
\text { miles }\end{array}$} \\
\hline & & $\begin{array}{l}\text { Current } \\
(2017)\end{array}$ & $\begin{array}{l}\text { Future } \\
(2030)\end{array}$ & \\
\hline Appling County, GA & FCEV & 0.00 & 0.00 & 12 \\
\hline Toombs County, GA & FCEV & 0.00 & 0.00 & 20 \\
\hline Jeff Davis County, GA & FCEV & 0.00 & 0.00 & 21 \\
\hline Montgomery County, GA & FCEV & 0.00 & 0.00 & 22 \\
\hline Tattnall County, GA & FCEV & 0.00 & 0.00 & 25 \\
\hline Bacon County, GA & FCEV & 0.00 & 0.00 & 30 \\
\hline Evans County, GA & FCEV & 0.00 & 0.00 & 37 \\
\hline Treutlen County, GA & FCEV & 0.00 & 0.00 & 39 \\
\hline Wayne County, GA & FCEV & 0.00 & 0.00 & 42 \\
\hline Candler County, GA & FCEV & 0.00 & 0.00 & 44 \\
\hline Jesup Plant: Rayonier Advanced Materials & NG Electricity Generators & 1.43 & 1.43 & 46 \\
\hline Pierce County, GA & FCEV & 0.00 & 0.00 & 47 \\
\hline Coffee County, GA & FCEV & 0.00 & 0.00 & 49 \\
\hline Emanuel County, GA & FCEV & 0.00 & 0.00 & 50 \\
\hline Long County, GA & FCEV & 0.00 & 0.00 & 51 \\
\hline Ware County, GA & FCEV & 0.00 & 0.00 & 56 \\
\hline Liberty County, GA & FCEV & 0.00 & 0.00 & 59 \\
\hline Bulloch County, GA & FCEV & 0.00 & 0.00 & 59 \\
\hline Laurens County, GA & FCEV & 0.00 & 0.00 & 61 \\
\hline Dodge County, GA & FCEV & 0.00 & 0.00 & 63 \\
\hline Johnson County, GA & FCEV & 0.00 & 0.00 & 64 \\
\hline Brantley County, GA & FCEV & 0.00 & 0.00 & 64 \\
\hline Ben Hill County, GA & FCEV & 0.00 & 0.00 & 67 \\
\hline Atkinson County, GA & FCEV & 0.00 & 0.00 & 67 \\
\hline Bryan County, GA & FCEV & 0.00 & 0.00 & 69 \\
\hline
\end{tabular}




\begin{tabular}{|c|c|c|c|c|}
\hline Jenkins County, GA & FCEV & 0.00 & 0.00 & 70 \\
\hline Irwin County, GA & FCEV & 0.00 & 0.00 & 70 \\
\hline Interstate Paper LLC Riceboro: Interstate Paper LLC & NG Electricity Generators & 0.20 & 0.20 & 72 \\
\hline Wilcox County, GA & FCEV & 0.00 & 0.00 & 74 \\
\hline Effingham County, GA & FCEV & 0.00 & 0.00 & 79 \\
\hline Bleckley County, GA & FCEV & 0.00 & 0.00 & 79 \\
\hline McIntosh County, GA & FCEV & 0.00 & 0.00 & 80 \\
\hline Brunswick Cellulose: Brunswick Cellulose LLC & NG Electricity Generators & 1.10 & 1.10 & 81 \\
\hline Pulaski County, GA & FCEV & 0.00 & 0.00 & 81 \\
\hline $\begin{array}{l}\text { Effingham County Power Project: SEPG Operating Services, LLC } \\
\text { Effingham }\end{array}$ & NG Electricity Generators & 13.00 & 13.00 & 82 \\
\hline Screven County, GA & FCEV & 0.00 & 0.00 & 82 \\
\hline PInova Inc: PInova Inc & NG Electricity Generators & 0.13 & 0.13 & 83 \\
\hline Clinch County, GA & FCEV & 0.00 & 0.00 & 83 \\
\hline Jefferson County, GA & FCEV & 0.00 & 0.00 & 85 \\
\hline Washington County, GA & FCEV & 0.00 & 0.00 & 86 \\
\hline Savannah River Mill: Georgia-Pacific Consr Prods LP-Savannah & NG Electricity Generators & 0.52 & 0.52 & 86 \\
\hline Berrien County, GA & FCEV & 0.00 & 0.00 & 88 \\
\hline Tift County, GA & FCEV & 0.00 & 0.00 & 88 \\
\hline International Paper Savanna Mill: International Paper Co & NG Electricity Generators & 3.85 & 3.85 & 88 \\
\hline Lanier County, GA & FCEV & 0.00 & 0.00 & 89 \\
\hline Chatham County, GA & FCEV & 0.00 & 0.00 & 89 \\
\hline Turner County, GA & FCEV & 0.00 & 0.00 & 90 \\
\hline Imperial Savannah LP: Imperial Savannah LP & NG Electricity Generators & 1.38 & 1.38 & 90 \\
\hline Wilkinson County, GA & FCEV & 0.00 & 0.00 & 90 \\
\hline McIntosh Combined Cycle Facility: Georgia Power Co & NG Electricity Generators & 46.19 & 46.19 & 92 \\
\hline Charlton County, GA & FCEV & 0.00 & 0.00 & 92 \\
\hline Burke County, GA & FCEV & 0.00 & 0.00 & 93 \\
\hline McIntosh: Georgia Power Co & NG Electricity Generators & 0.48 & 0.48 & 93 \\
\hline Port Wentworth Mill: International Paper Port Wentworth Mill & NG Electricity Generators & 0.86 & 0.86 & 93 \\
\hline
\end{tabular}


Crisp County, GA

Mid-Georgia Cogeneration Facility: SEPG Operating Services, LLC

MGC

Twiggs County, GA

AL Sandersville LLC: SEPG Operating Services, LLC ALS
FCEV

0.00

0.91

NG Electricity Generators

FCEV

NG Electricity Generators
0.00

97

0.00

0.01

98

98

99 


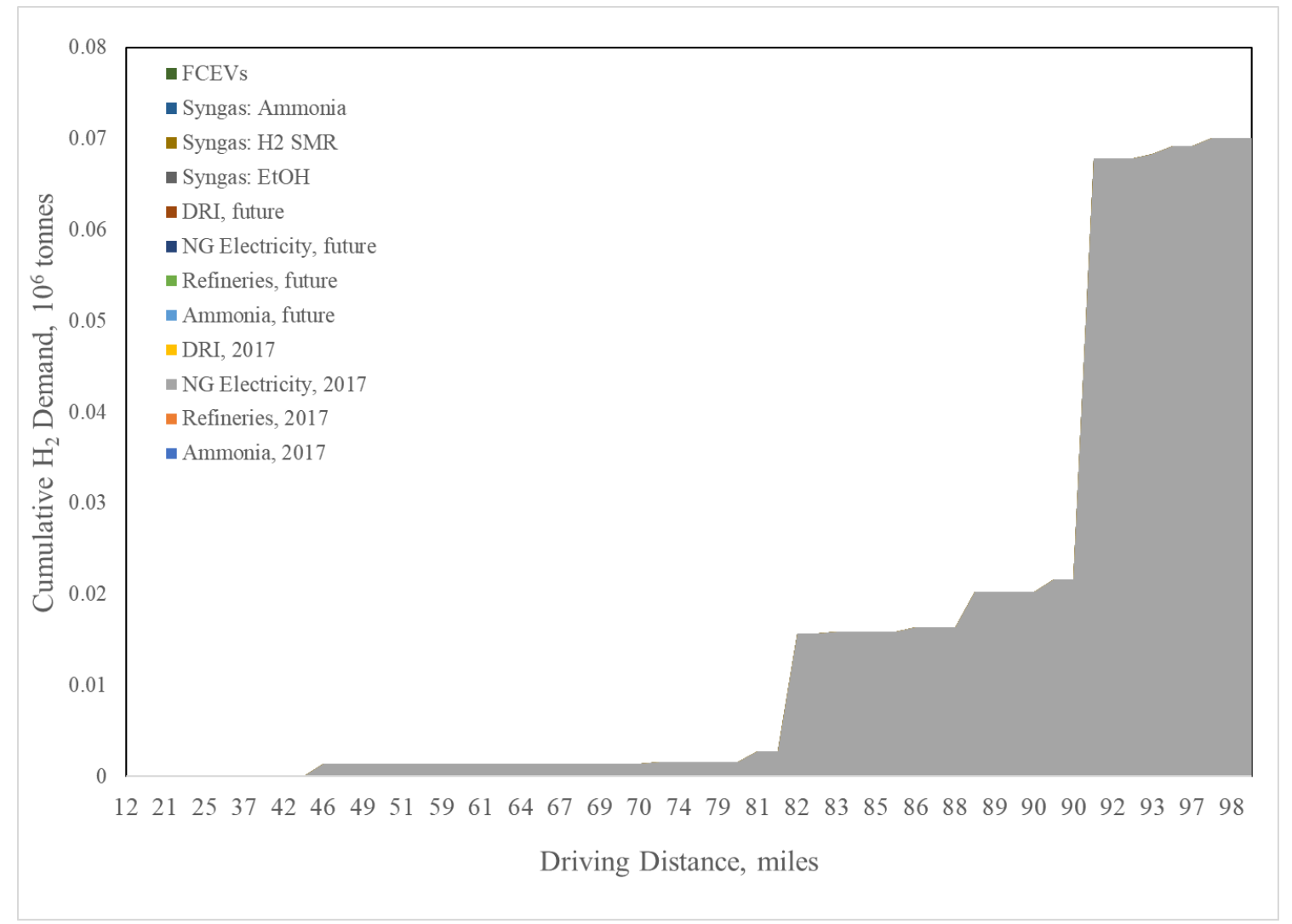

Figure 42. Cumulative potential hydrogen demand by type and distance near the Hatch NPP.

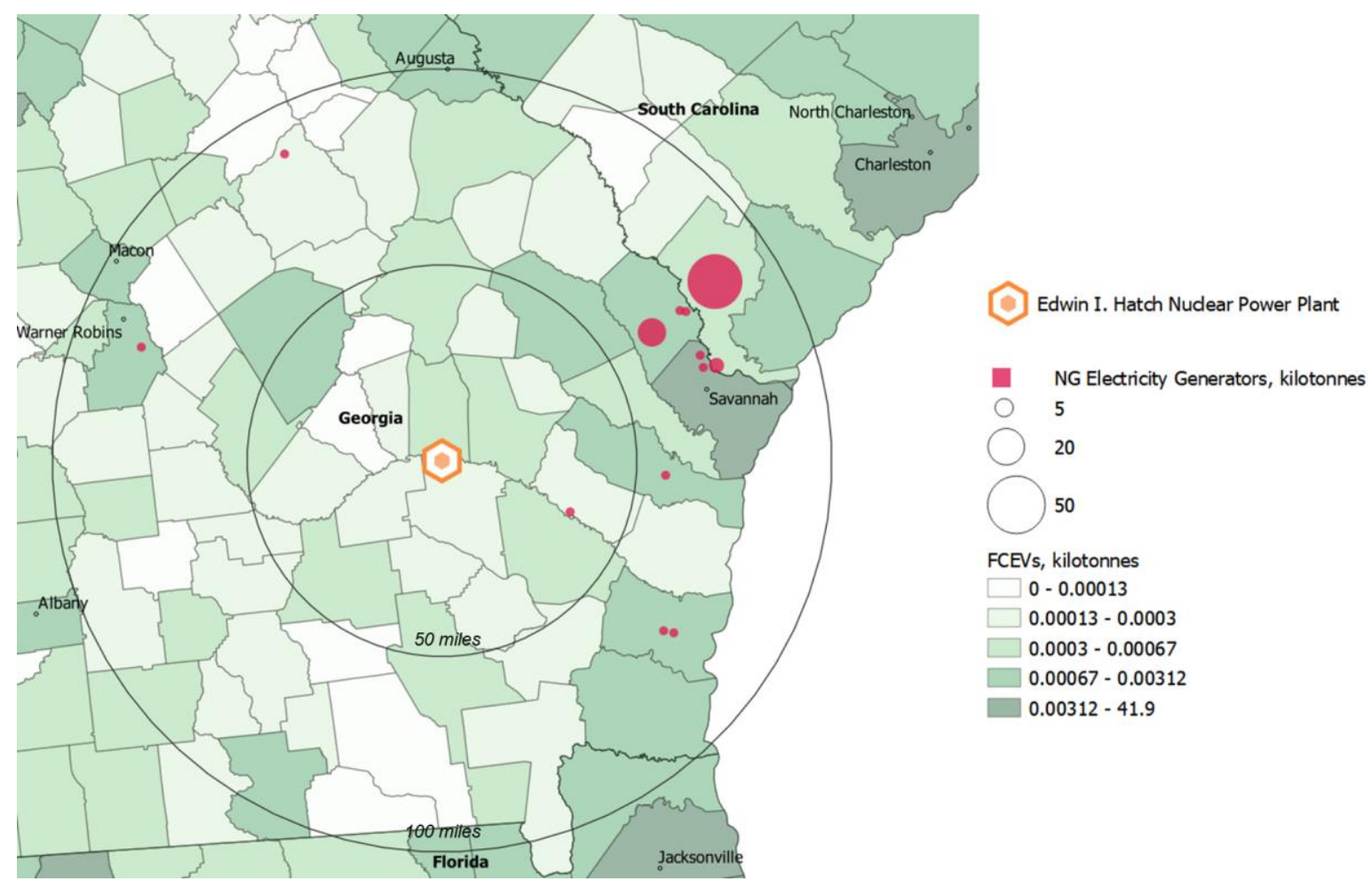

Figure 43. Future potential hydrogen demand near the Hatch NPP. 


\subsubsection{Vogtle NPP, Augusta, GA}

The total near-term potential hydrogen demand within 100 miles of the Vogtle Generating Station is 670 MT/day. Half of this demand is associated with the Nutrien's Augusta facility, producing ammonia within 34 miles, with a potential hydrogen demand of $350 \mathrm{MT} /$ day. Most of the other half-i.e., 320 MT/day - is for co-combustion of hydrogen with NG in 19 gas electricity generators. Of this, 210 MT/day is associated with two NG generators, Georgia Power's McIntosh, and the South Carolina Electric and Gas Company's Jasper, at distances of 78 and 85 miles, respectively, from NPP (see Table 15 and Figure 44).

The most notable increase in future potential hydrogen demand near the Vogtle Generating Station is 380 MT/day for production of synfuels using Nutrien Augusta's by-product $\mathrm{CO}_{2}$. The total future potential demand around the Vogtle facility is 1000 MT/day. Future demand is represented in Figure 45. 
Table 15. Hydrogen Demand within 100 miles of the Vogtle NPP.

\begin{tabular}{|c|c|c|c|c|}
\hline \multirow[b]{2}{*}{ Name } & \multirow[b]{2}{*}{ Demand Type } & \multicolumn{2}{|c|}{$\begin{array}{l}\text { Potential H2 Demand, } \\
\text { kilotonnes }\end{array}$} & \multirow[b]{2}{*}{$\begin{array}{l}\text { Distance, } \\
\text { miles }\end{array}$} \\
\hline & & $\begin{array}{l}\text { Current } \\
(2017)\end{array}$ & $\begin{array}{l}\text { Future } \\
(2030)\end{array}$ & \\
\hline Burke County, GA & FCEV & 0.00 & 0.00 & 19 \\
\hline International Paper Augusta Mill: International Paper Co-Augusta & NG Electricity Generators & 2.17 & 2.17 & 24 \\
\hline Richmond County, GA & FCEV & 0.00 & 0.00 & 33 \\
\hline Nutrien, Augusta & Ammonia & 127.00 & 127.00 & 35 \\
\hline Jenkins County, GA & FCEV & 0.00 & 0.00 & 36 \\
\hline Nutrien, Augusta & Syngas: Ammonia CO2 & 0.00 & 140.15 & 36 \\
\hline Screven County, GA & FCEV & 0.00 & 0.00 & 36 \\
\hline Urquhart: South Carolina Electric\&Gas Company & NG Electricity Generators & 13.77 & 13.77 & 37 \\
\hline Allendale County, SC & FCEV & 0.00 & 0.00 & 42 \\
\hline Columbia County, GA & FCEV & 0.00 & 0.00 & 45 \\
\hline Jefferson County, GA & FCEV & 0.00 & 0.00 & 48 \\
\hline Aiken County, SC & FCEV & 0.00 & 0.00 & 50 \\
\hline Kamin LLC Wrens Plant: Kamin LLC & NG Electricity Generators & 0.02 & 0.02 & 52 \\
\hline Barnwell County, SC & FCEV & 0.00 & 0.00 & 57 \\
\hline Hampton County, SC & FCEV & 0.00 & 0.00 & 59 \\
\hline Edgefield County, SC & FCEV & 0.00 & 0.00 & 59 \\
\hline Emanuel County, GA & FCEV & 0.00 & 0.00 & 61 \\
\hline Bulloch County, GA & FCEV & 0.00 & 0.00 & 61 \\
\hline Glascock County, GA & FCEV & 0.00 & 0.00 & 62 \\
\hline McDuffie County, GA & FCEV & 0.00 & 0.00 & 64 \\
\hline Bamberg County, SC & FCEV & 0.00 & 0.00 & 66 \\
\hline Candler County, GA & FCEV & 0.00 & 0.00 & 66 \\
\hline Warren County, GA & FCEV & 0.00 & 0.00 & 67 \\
\hline Washington County, GA & FCEV & 0.00 & 0.00 & 68 \\
\hline Lincoln County, GA & FCEV & 0.00 & 0.00 & 70 \\
\hline
\end{tabular}




\begin{tabular}{|c|c|c|c|c|}
\hline Cope: South Carolina Electric\&Gas Company & NG Electricity Generators & 1.19 & 1.19 & 73 \\
\hline McCormick County, SC & FCEV & 0.00 & 0.00 & 73 \\
\hline Effingham County, GA & FCEV & 0.00 & 0.00 & 74 \\
\hline $\begin{array}{l}\text { Effingham County Power Project: SEPG Operating Services, LLC } \\
\text { Effingham }\end{array}$ & NG Electricity Generators & 13.00 & 13.00 & 75 \\
\hline Johnson County, GA & FCEV & 0.00 & 0.00 & 75 \\
\hline Savannah River Mill: Georgia-Pacific Consr Prods LP-Savannah & NG Electricity Generators & 0.52 & 0.52 & 77 \\
\hline AL Sandersville LLC: SEPG Operating Services, LLC ALS & NG Electricity Generators & 0.01 & 0.01 & 78 \\
\hline McIntosh Combined Cycle Facility: Georgia Power Co & NG Electricity Generators & 46.19 & 46.19 & 79 \\
\hline McIntosh: Georgia Power Co & NG Electricity Generators & 0.48 & 0.48 & 80 \\
\hline Colleton County, SC & FCEV & 0.00 & 0.00 & 83 \\
\hline Treutlen County, GA & FCEV & 0.00 & 0.00 & 84 \\
\hline Saluda County, SC & FCEV & 0.00 & 0.00 & 85 \\
\hline Bull Street Plant: City of Orangeburg - (SC) & NG Electricity Generators & 0.00 & 0.00 & 85 \\
\hline Jasper: South Carolina Electric\&Gas Company & NG Electricity Generators & 30.26 & 30.26 & 85 \\
\hline Rowesville Rd Plant: City of Orangeburg - (SC) & NG Electricity Generators & 0.00 & 0.00 & 86 \\
\hline $\begin{array}{l}\text { Washington County Power LLC: SEPG Operating Services, LLC } \\
\text { WCP }\end{array}$ & NG Electricity Generators & 0.92 & 0.92 & 87 \\
\hline Evans County, GA & FCEV & 0.00 & 0.00 & 87 \\
\hline Wilkes County, GA & FCEV & 0.00 & 0.00 & 87 \\
\hline Jasper County, SC & FCEV & 0.00 & 0.00 & 88 \\
\hline Hancock County, GA & FCEV & 0.00 & 0.00 & 88 \\
\hline Port Wentworth Mill: International Paper Port Wentworth Mill & NG Electricity Generators & 0.86 & 0.86 & 88 \\
\hline Substation 20 Plant: City of Orangeburg - (SC) & NG Electricity Generators & 0.00 & 0.00 & 88 \\
\hline Imperial Savannah LP: Imperial Savannah LP & NG Electricity Generators & 1.38 & 1.38 & 89 \\
\hline Orangeburg County, SC & FCEV & 0.00 & 0.00 & 89 \\
\hline Taliaferro County, GA & FCEV & 0.00 & 0.00 & 89 \\
\hline Toombs County, GA & FCEV & 0.00 & 0.00 & 89 \\
\hline International Paper Savanna Mill: International Paper Co & NG Electricity Generators & 3.85 & 3.85 & 93 \\
\hline Lexington County, SC & FCEV & 0.00 & 0.00 & 94 \\
\hline
\end{tabular}


WestRock Southeast, LLC.: SP Fiber Technologies LLC

Laurens County, GA

Tattnall County, GA

Chatham County, GA

Greenwood County, SC

Montgomery County, GA

McMeekin: South Carolina Electric\&Gas Company

Calhoun County, SC
NG Electricity Generators

FCEV

FCEV

FCEV

FCEV

FCEV

NG Electricity Generators

FCEV
$0.64 \quad 0.64$

$0.00 \quad 0.00$

$0.00 \quad 0.00$

$0.00 \quad 0.00$

$0.00 \quad 0.00$

$0.00 \quad 0.00$

$\begin{array}{ll}2.78 & 2.78\end{array}$

$0.00 \quad 0.00$
94

95

95

96

97

98

99 


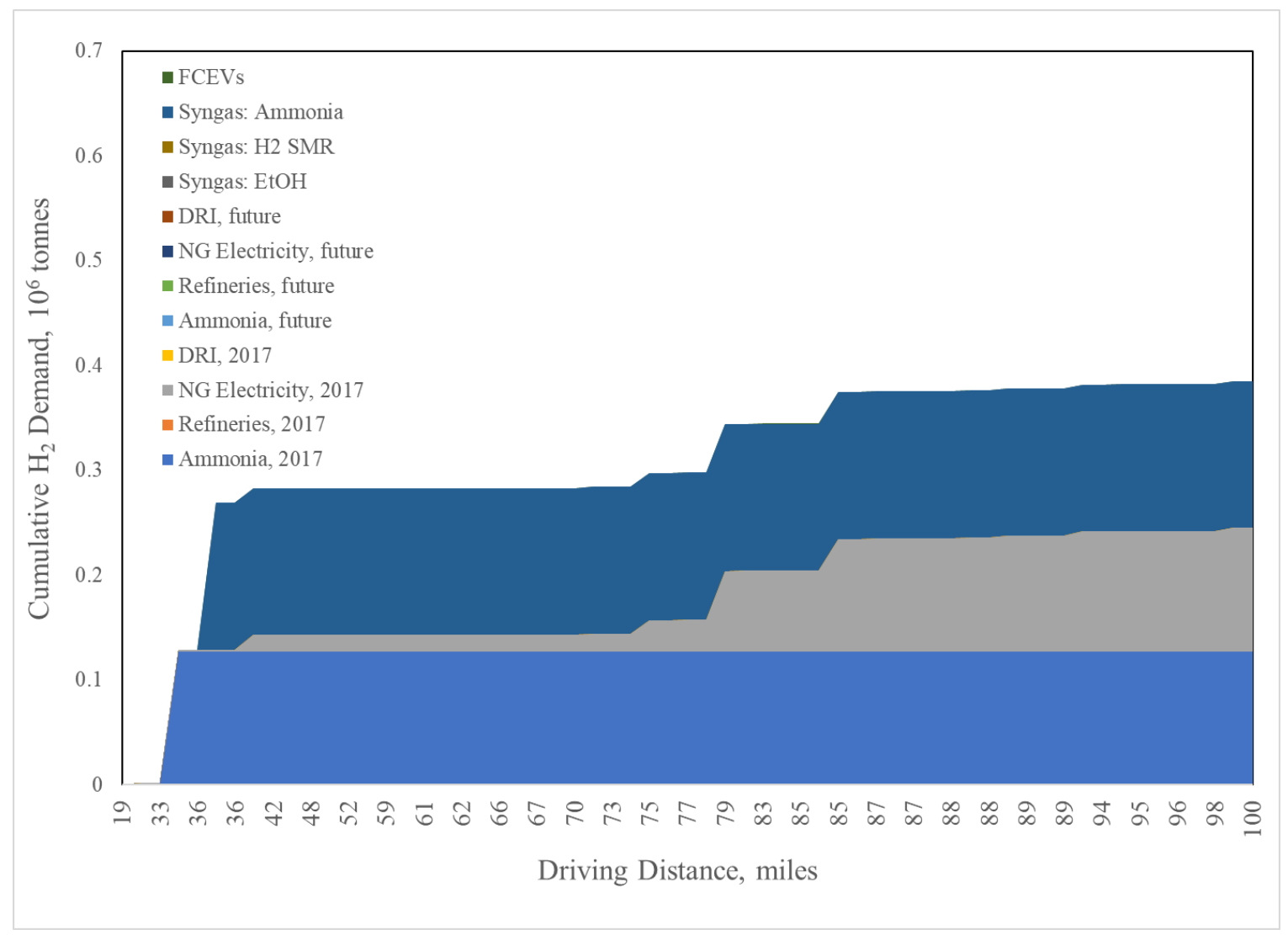

Figure 44. Cumulative potential hydrogen demand by type and distance near Vogtle generating station.

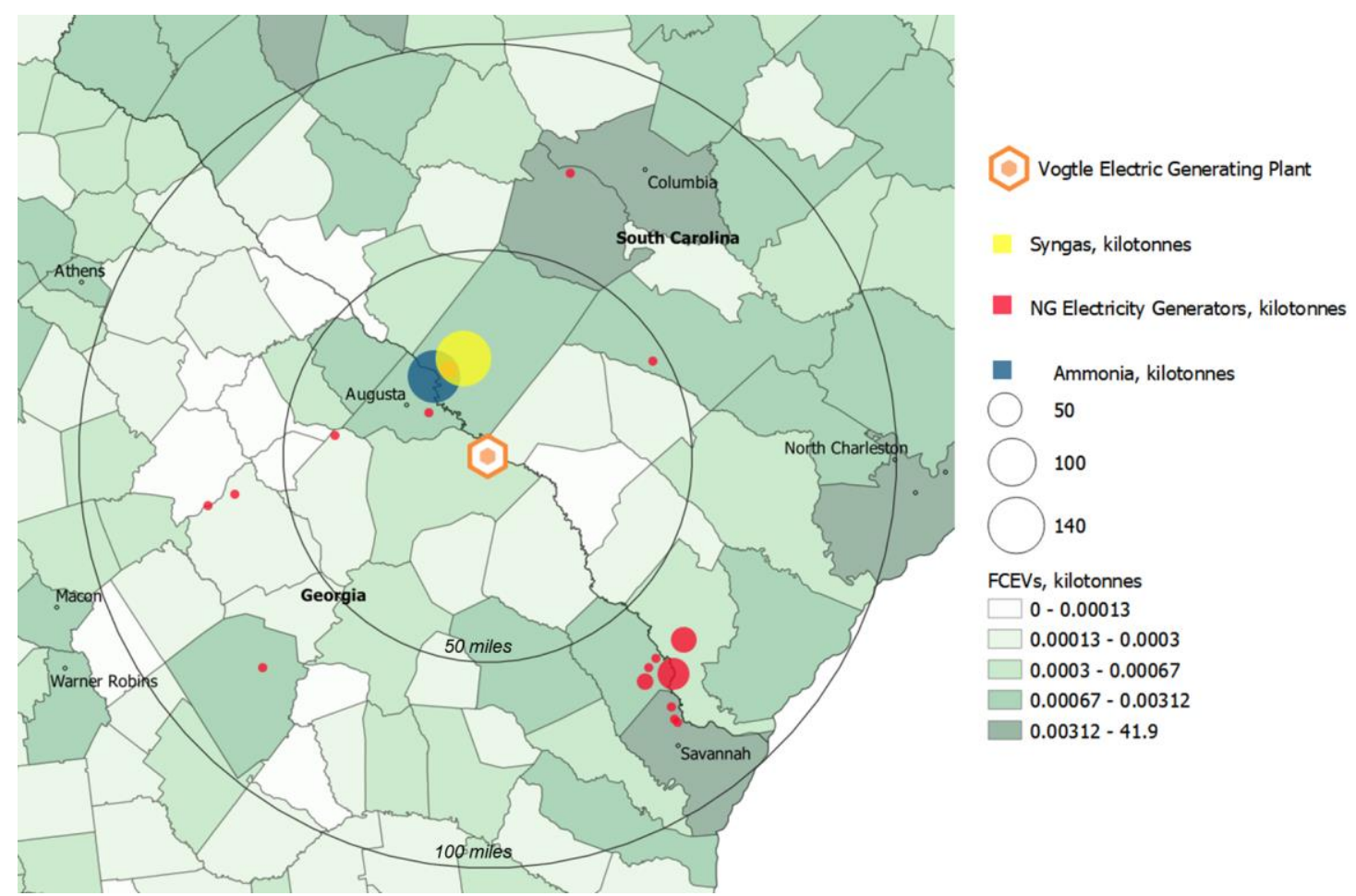

Figure 45. Future potential hydrogen demand near the Vogtle generating station. 


\subsection{Arizona Region}

\subsubsection{Palo Verde NPP, Tonopah, AZ}

The Arizona Public Service (APS) Company's Palo Verde Nuclear generating station is the largest power plant in the U.S., producing $3.8 \mathrm{GW}$ of electricity (assuming a 93\% capacity factor, for roughly 8,200 hours per year). It supplies electricity to densely populated parts of Southern Arizona and Southern California - e.g., Phoenix and Tucson, Arizona, Los Angeles and San Diego, California. Possible nongrid electricity demand sources are discussed below, along with a broad analysis of market and technical challenges.

\subsubsection{Water desalination}

Providing potable water for Arizona's large and growing population, as well as extensive agriculture, is of critical importance to Arizona's economy. Five million of Arizona's roughly 7 million residents live in the Phoenix metropolitan area, which is one of the fastest-growing large cities in the country ${ }^{96}$. As a whole, Arizona used 2.3T gallons of water in 2018 (7.1 acre-feet, a standard measure of water consumption $)^{97}$. Seventy-four percent of this water was designated for agricultural use while $21 \%$ was for municipal use, leaving $5 \%$ for industrial use, statewide. Roughly 55\% of this supply comes from rivers, with another $40 \%$ coming from groundwater ${ }^{98}$. Arizona has strict groundwater-use regulations under the Groundwater Management Act of $1980^{99}$. Should the availability of these resources be impacted, NPPassociated reverse osmosis (RO) purification of briny-water sources (either from aquifers or ocean water) could help fill any potential gaps. Care should be taken when identifying potential briny-water sources to consider the sustainability and long-term future of the water source under conditions of increasing population.

A first-estimate analysis of energy requirements suggests that the Palo Verde plant could provide the desalination electricity to supply more than $95 \%$ of Arizona's yearly potable water. Recent analyses estimate that a RO plant with a typical seawater feedstock consumes around $14 \mathrm{Wh} /$ gallon of potable water produced $^{100}$. Improvements in RO membrane and plant technologies could reduce this number further. Applying current technology, the Palo Verde plant could theoretically purify $2.2 \mathrm{~T}$ gallons of water per year, or more than $95 \%$ of the Arizona's total water requirements.

Given the cost of RO processes and the risks of centralized water production, it is unlikely that the state's entire water supply would be derived from a single purification plant. However, a waterpurification facility could be considered as part of a comprehensive strategy for the Palo Verde plant wherein a wide variety of products, chemical or otherwise, are produced.

\subsubsection{Energy Industrial Park}

The chemicals and plastics industries do not currently have a significant foothold in Arizona, but the centralized energy offered by the Palo Verde plant could provide an entry point via the energy industrial park model. Palo Verde is less than 1,000 miles from the Permian basin, the site of major oil and NG deposits. Products from this region are generally shipped over 500 miles via pipeline to refineries on the U.S. Gulf Coast but could reasonably be taken in the opposite direction to Arizona at the same cost, given the similar distances. An energy industrial park using NG-derived ethane and propane, plus $\mathrm{CO}_{2}$, to produce a variety of chemical products (ethylene, propylene, olefin derivatives, FA, hydrogen, syngas, etc.) could theoretically produce massive amounts of material using the energy from Palo Verde. This would represent a new growth industry for Arizona and would likely attract demand in the form of downstream polymer and plastics manufacturers, spurring growth in the region. Thus, a new chemical manufacturing facility in central Arizona could feasibly use advantaged feedstock, in the form of Texasbased NG, and provide polymer and plastics products to large population centers in Phoenix and Southern California. In addition, the Palo Verde plant is conveniently located for product distribution. The facility is located near both the Interstate-10 road corridor for truck shipment and a near-dormant rail line for train shipment. Admittedly, this proposal faces a number of challenges, both technical (e.g., the low TRL 
of paraffin-deprotonating electrolysis cells) and market (e.g., the lack of current infrastructure or related investment in the region).

\subsubsection{Hydrogen Demand}

This analysis considers Palo Verde's potential opportunities for marketing near zero-carbon hydrogen which it could produce (see Table 16). Figure 46 shows potential cumulative hydrogen demand within 400 miles of the Palo Verde generating stations' facility.

Figure 46 includes both current and future potential hydrogen demand estimates, with the current demand shown below the future demand to facilitate interpretation. Hydrogen demand values are stacked such that the Y-axis is the sum of hydrogen demands for each demand type plus those below it in the legend. Figure 47 illustrates the locations of potential hydrogen demand near the Palo Verde GS facilities. Each facility is marked with a hexagon while large concentric circles show distances of 100, and 400 miles around the facility. Locations of potential hydrogen demand are depicted by colored circles with size reflecting the scale of potential demand.

Current hydrogen demand within 400 miles of the Palo Verde generating station is predominantly for petroleum refining and co-combustion of hydrogen with NG. The cumulative current hydrogen demand within 400 miles of the generating station is approximately $3000 \mathrm{MT} /$ day. About $200 \mathrm{NG}$ electricity generators have a combined potential hydrogen demand of $1600 \mathrm{MT} /$ day for co-combustion with hydrogen. There are roughly 10 refineries that have a combined hydrogen demand of $1450 \mathrm{MT} / \mathrm{day}$, with two of them making up approximately half of that demand. The Tesoro Corporation in Carson, California, and Chevron Corporation in El Segundo, California, each has a current hydrogen demand of approximately $350 \mathrm{MT} /$ day.

The potential hydrogen demand in the future scenario for the Palo Verde Generating Station is about $5800 \mathrm{MT} /$ day (or 2.1 MMT/year) from potential facilities within 400 miles. The majority of the future potential hydrogen demand is from synfuel-producing facilities, refineries, NG electricity generators, and FCEVs in California. The potential synfuels market will have hydrogen demand of up to 2000 MT/day. The 10 refiners will likely increase their hydrogen demand in the future, for a total potential demand of $1830 \mathrm{MT} /$ day. In the future, FCEVs in California are expected to increase rapidly in their demand for H2, to $280 \mathrm{MT} /$ day, with the Los Angeles County contributing the highest potential hydrogen demand of about $120 \mathrm{MT} /$ day (sufficient for $\sim 200,000$ FCEVs). 


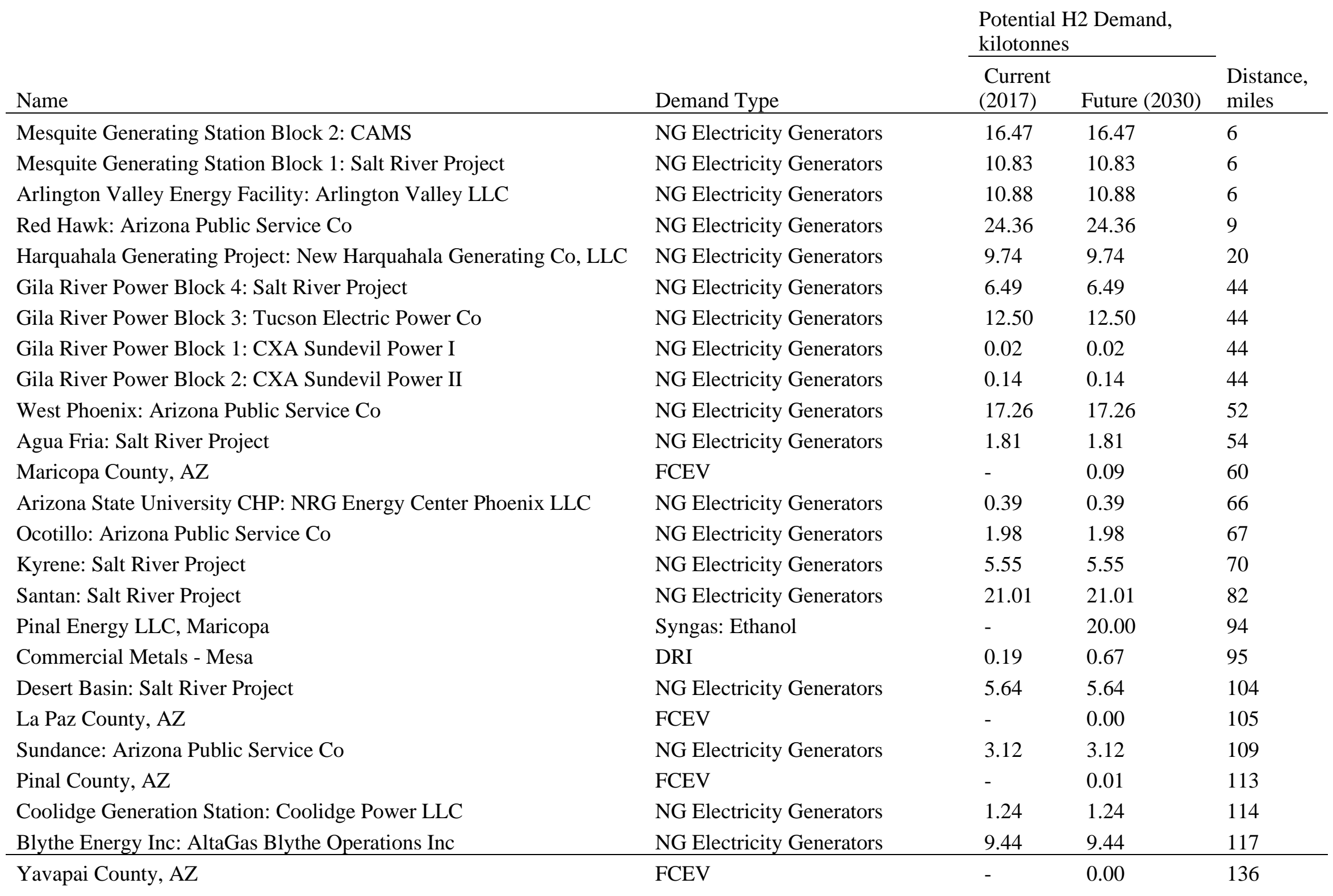


Saguaro: Arizona Public Service Co

North Loop: Tucson Electric Power Co

Yuma County, AZ

Yuma Cogeneration Associates: Falcon Power Operating Company

Yucca: Arizona Public Service Co

Demoss Petrie: Tucson Electric Power Co

University of Arizona - Biosphere 2: University of Arizona -

Biosphere 2

Cogeneration 2: University of Arizona

Pima County, AZ

Cogeneration 1: University of Arizona

H Wilson Sundt Generating Station: Tucson Electric Power Co

Gila County, AZ

Black Mountain Generating Station: UNS Electric, Inc

Griffith Energy LLC: Star West Gen Griffith Energy LLC

Mohave County, AZ

Rockwood: Imperial Irrigation District

Desert View Power: Desert View Power Inc

Spreckels Sugar Company: Spreckels Sugar Company

Coachella: Imperial Irrigation District

Imperial County, CA

Novo BioPower Plant: Novo Biopower LLC

Graham County, AZ

Niland Gas Turbine Plant: Imperial Irrigation District

Coconino County, AZ

El Centro: Imperial Irrigation District

Municipal Cogen Plant: Palm Springs City of

Santa Cruz County, AZ

Indigo Energy Facility: Diamond Generating Corporation

Valencia: UNS Electric, Inc

\begin{tabular}{|c|c|c|c|}
\hline NG Electricity Generators & 0.54 & 0.54 & 139 \\
\hline NG Electricity Generators & 0.00 & 0.00 & 157 \\
\hline FCEV & - & 0.00 & 159 \\
\hline NG Electricity Generators & 0.10 & 0.10 & 162 \\
\hline NG Electricity Generators & 2.70 & 2.70 & 166 \\
\hline NG Electricity Generators & 0.00 & 0.00 & 167 \\
\hline NG Electricity Generators & 0.00 & 0.00 & 168 \\
\hline NG Electricity Generators & 0.35 & 0.35 & 169 \\
\hline FCEV & - & 0.02 & 170 \\
\hline NG Electricity Generators & 0.48 & 0.48 & 170 \\
\hline NG Electricity Generators & 6.32 & 6.32 & 176 \\
\hline FCEV & - & 0.00 & 182 \\
\hline NG Electricity Generators & 0.42 & 0.42 & 191 \\
\hline NG Electricity Generators & 10.73 & 10.73 & 192 \\
\hline FCEV & - & 0.00 & 193 \\
\hline NG Electricity Generators & 0.02 & 0.02 & 200 \\
\hline NG Electricity Generators & 0.03 & 0.03 & 205 \\
\hline NG Electricity Generators & 0.96 & 0.96 & 205 \\
\hline NG Electricity Generators & 0.03 & 0.03 & 208 \\
\hline FCEV & - & 0.75 & 208 \\
\hline NG Electricity Generators & 0.00 & 0.00 & 214 \\
\hline FCEV & - & 0.00 & 215 \\
\hline NG Electricity Generators & 0.52 & 0.52 & 216 \\
\hline FCEV & - & 0.00 & 217 \\
\hline NG Electricity Generators & 6.42 & 6.42 & 217 \\
\hline NG Electricity Generators & 0.02 & 0.02 & 226 \\
\hline FCEV & - & 0.00 & 227 \\
\hline NG Electricity Generators & 0.55 & 0.55 & 230 \\
\hline NG Electricity Generators & 0.04 & 0.04 & 231 \\
\hline
\end{tabular}


Sentinel Energy Center, LLC: CPV Sentinel LLC

Navajo County, AZ

Apache Station: Arizona Electric Pwr Coop Inc

MCAGCC Cogen Plant: DOD USMC Marine Air Ground Combat

Cochise County, AZ

Cholla: Arizona Public Service Co

Nevada Solar One: Acciona Solar Power

Desert Star Energy Center: Desert Star Energy Center SDG\&E

Greenlee County, AZ

Energy Center: University of Redlands

Saguaro Power: Saguaro Power Co

Clark (NVE): Nevada Power Co

Ivanpah 2: NRG Energy Services

Mountainview Generating Station: Southern California Edison Co

Springs Generating Station: City of Riverside - (CA)

Riverside County, CA

Nevada Cogen Associates 2 Black Mountain: Nevada Cogeneration

Assoc \# 2

Ivanpah 1: NRG Energy Services

Amazon San Bernardino: Bloom Energy

Loma Linda University Cogen: Loma Linda University

Ivanpah 3: NRG Energy Services

Higgins Generating Station: Nevada Power Co

Inland Empire Energy Center: Inland Empire Energy Ctr LLC

Drews Generating Facility: Colton Power LP

Century Generating Facility: Colton Power LP

Sun Peak Generating Station: Nevada Power Co

Clark County, NV

Agua Mansa Power Plant: E I Colton LLC

CityCenter Central Plant Cogen Units: CityCenter Land LLC
NG Electricity Generators

FCEV

NG Electricity Generators

NG Electricity Generators

FCEV

NG Electricity Generators

NG Electricity Generators

NG Electricity Generators FCEV

NG Electricity Generators

NG Electricity Generators

NG Electricity Generators

NG Electricity Generators

NG Electricity Generators

NG Electricity Generators

FCEV

NG Electricity Generators

NG Electricity Generators

NG Electricity Generators

NG Electricity Generators

NG Electricity Generators

NG Electricity Generators

NG Electricity Generators

NG Electricity Generators

NG Electricity Generators

NG Electricity Generators

FCEV

NG Electricity Generators

NG Electricity Generators

\begin{tabular}{|c|c|c|}
\hline 3.54 & 3.54 & 233 \\
\hline- & 0.00 & 243 \\
\hline 1.44 & 1.44 & 244 \\
\hline 0.74 & 0.74 & 244 \\
\hline- & 0.00 & 249 \\
\hline 0.00 & 0.00 & 256 \\
\hline 0.03 & 0.03 & 261 \\
\hline 5.99 & 5.99 & 262 \\
\hline- & 0.00 & 264 \\
\hline 0.04 & 0.04 & 270 \\
\hline 4.88 & 4.88 & 272 \\
\hline 6.38 & 6.38 & 275 \\
\hline 0.30 & 0.30 & 275 \\
\hline 23.10 & 23.10 & 275 \\
\hline 0.01 & 0.01 & 275 \\
\hline- & 9.99 & 275 \\
\hline 5.01 & 5.01 & 276 \\
\hline 0.31 & 0.31 & 276 \\
\hline 0.04 & 0.04 & 276 \\
\hline 0.74 & 0.74 & 276 \\
\hline 0.30 & 0.30 & 278 \\
\hline 14.25 & 14.25 & 279 \\
\hline 1.97 & 1.97 & 279 \\
\hline 0.02 & 0.02 & 281 \\
\hline 0.02 & 0.02 & 281 \\
\hline 0.19 & 0.19 & 282 \\
\hline- & 11.16 & 283 \\
\hline 0.09 & 0.09 & 283 \\
\hline 0.47 & 0.47 & 284 \\
\hline
\end{tabular}


Nevada Cogen Assoc\#1 GarnetVly: Nevada Cogeneration Assoc \# 1 Cal State Univ San Bernardino FC01: Southern California Edison Co San Bernardino County, CA

Riverside RWQCP Fuel Cell: Riverside Fuel Cell, LLC

Riverside Energy Resource Center: City of Riverside - (CA)

Las Vegas Generating Station: Nevada Power Co

Etiwanda Generating Station: NRG California South LP

Praxair Ontario Ca

Mira Loma Peaker: Southern California Edison Co

Parallel Prodts Of California, Rancho Cucamonga

Gerdau Long Steel North America - California

Grapeland Peaker: Southern California Edison Co

New-Indy Ontario Mill: New-Indy Ontario LLC

Starbucks - Evolution Fresh: Bloom Energy

Kaiser Ontario: Bloom Energy 2009 PPA

Corona Energy Partners, Ltd: WCAC Operating Company

Clearwater Power Plant: City of Riverside - (CA)

San Antonio Regional Hospital: San Antonio Regional Hospital

OLS Energy Chino: OLS Energy-Chino

Bear Valley Power Plant: Golden State Water Company

Chuck Lenzie Generating Station: Nevada Power Co

Harry Allen: Nevada Power Co

Apex Generating Station: Los Angeles Department of Water and

Power

Silverhawk: Nevada Power Co

Anaheim GT: City of Anaheim - (CA)

Orange Grove Peaking Facility: Orange Grove Energy LP

Canyon Power Plant: City of Anaheim - (CA)

Walnut Creek Energy Park: NRG Walnut Creek LLC

Cuyamaca Peak Energy Plant: San Diego Gas and Electric Co
NG Electricity Generators

NG Electricity Generators

FCEV

NG Electricity Generators

NG Electricity Generators

NG Electricity Generators

NG Electricity Generators

Syngas: Hydrogen, SMR

NG Electricity Generators

Syngas: Ethanol

DRI

NG Electricity Generators

NG Electricity Generators

NG Electricity Generators

NG Electricity Generators

NG Electricity Generators

NG Electricity Generators

NG Electricity Generators

NG Electricity Generators

NG Electricity Generators

NG Electricity Generators

NG Electricity Generators

NG Electricity Generators

NG Electricity Generators

NG Electricity Generators

NG Electricity Generators

NG Electricity Generators

NG Electricity Generators

NG Electricity Generators

\begin{tabular}{|c|c|c|}
\hline 4.65 & 4.65 & 286 \\
\hline 0.06 & 0.06 & 286 \\
\hline- & 8.90 & 287 \\
\hline 0.00 & 0.00 & 287 \\
\hline 0.73 & 0.73 & 287 \\
\hline 2.21 & 2.21 & 290 \\
\hline 1.24 & 1.24 & 292 \\
\hline- & 9.68 & 292 \\
\hline 0.18 & 0.18 & 292 \\
\hline- & - & 293 \\
\hline 0.50 & 1.76 & 293 \\
\hline 0.19 & 0.19 & 293 \\
\hline 2.58 & 2.58 & 293 \\
\hline 0.04 & 0.04 & 294 \\
\hline 0.01 & 0.01 & 294 \\
\hline 0.68 & 0.68 & 295 \\
\hline 0.17 & 0.17 & 298 \\
\hline 0.12 & 0.12 & 299 \\
\hline 1.44 & 1.44 & 302 \\
\hline 0.01 & 0.01 & 309 \\
\hline 33.76 & 33.76 & 310 \\
\hline 17.76 & 17.76 & 311 \\
\hline 16.42 & 16.42 & 312 \\
\hline 12.77 & 12.77 & 312 \\
\hline 0.55 & 0.55 & 312 \\
\hline 0.35 & 0.35 & 312 \\
\hline 1.27 & 1.27 & 313 \\
\hline 2.50 & 2.50 & 314 \\
\hline 0.07 & 0.07 & 314 \\
\hline
\end{tabular}


El Cajon Energy Center: El Cajon Energy LLC

Fullerton Mill CHP: Kimberly-Clark Worldwide Inc

CSUF Trigeneration: California State University at Fullerton

AT\&T Anaheim: Bloom Energy

Grossmont Hospital: Sharp Grossmont Hospital

UCI Fuel Cell: UCI Fuel Cell, LLC

B Braun Medical: B Braun Medical Inc

MillerCoors Irwindale Brewery: MillerCoors Irwindale Brewery

Orange County, CA

Apache County, AZ

UCI Facilities Management Central Plant: University of California

\section{Irvine}

San Diego State University: San Diego State University

Barre Peaker: Southern California Edison Co

High Desert Power Plant: MRP Generation Holdings, LLC

CalPeak Power Enterprise Peaker Plant: Calpeak Operating Services, LLC

Goal Line LP: Goal Line LP

Escondido Energy Center: Wellhead Energy, LLC

Palomar Energy: San Diego Gas and Electric Co

Hidalgo County, NM

Biola University: Biola University

Lordsburg Generating: Public Service Co of NM

Plant No 1 Orange County: Orange County Sanitation Dist

Kearny: NRG Cabrillo Power Ops Inc

Wheelabrator Norwalk Energy: Wheelabrator Environmental Systems

Hoag Hospital Cogen Plant: Hoag Memorial Presbyterian Hospital

Plant No 2 Orange County: Orange County Sanitation Dist

Kyocera International Project: Kyocrea International, Ind

Childrens Hospital: DTE San Diego COGEN Inc.
NG Electricity Generators

NG Electricity Generators

NG Electricity Generators

NG Electricity Generators

NG Electricity Generators

NG Electricity Generators

NG Electricity Generators

NG Electricity Generators

FCEV

FCEV

NG Electricity Generators

NG Electricity Generators

NG Electricity Generators

NG Electricity Generators

NG Electricity Generators

NG Electricity Generators

NG Electricity Generators

NG Electricity Generators

FCEV

NG Electricity Generators

NG Electricity Generators

NG Electricity Generators

NG Electricity Generators

NG Electricity Generators

NG Electricity Generators

NG Electricity Generators

NG Electricity Generators

NG Electricity Generators

$\begin{array}{lll}0.11 & 0.11 & 314 \\ 0.73 & 0.73 & 315 \\ 0.26 & 0.26 & 316 \\ 0.05 & 0.05 & 316 \\ 19.44 & 19.44 & 317 \\ 0.07 & 0.07 & 318 \\ 0.42 & 0.42 & 319 \\ 0.11 & 0.11 & 320 \\ - & 13.15 & 320 \\ - & 0.00 & 322 \\ 0.94 & 0.94 & 322\end{array}$

$\begin{array}{lll}0.50 & 0.50 \quad 322\end{array}$

$\begin{array}{lll}0.25 & 0.25 & 323\end{array}$

$\begin{array}{lll}12.22 & 12.22 & 324\end{array}$

$\begin{array}{lll}0.10 & 0.10 \quad 324\end{array}$

$\begin{array}{lll}0.15 & 0.15 & 324\end{array}$

$\begin{array}{lll}0.34 & 0.34 & 324\end{array}$

$\begin{array}{lll}13.18 & 13.18 & 324\end{array}$

$\begin{array}{lll}- & 0.00 & 325\end{array}$

$\begin{array}{lll}0.12 & 0.12 & 325\end{array}$

$\begin{array}{lll}0.08 & 0.08 & 326\end{array}$

$\begin{array}{lll}0.03 & 0.03 & 327\end{array}$

$\begin{array}{lll}0.08 & 0.08 & 327\end{array}$

$\begin{array}{lll}0.31 & 0.31 & 328\end{array}$

$\begin{array}{lll}0.26 & 0.26 & 328\end{array}$

$\begin{array}{lll}0.00 & 0.00 & 328\end{array}$

$\begin{array}{lll}0.01 & 0.01 & 328\end{array}$

$\begin{array}{lll}0.30 & 0.30 & 328\end{array}$

14

5

6

16

19

20

20

22


San Diego County, CA

Naval Station Energy Facility: Applied Energy Inc

Naval Hospital Medical Center: Department of the Navy

AES Huntington Beach LLC: AES Huntington Beach LLC

C P Kelco San Diego Plant: CPKelco U S Inc

Center Peaker: Southern California Edison Co

Encina: NRG Cabrillo Power Ops Inc

NRG Energy San Diego: NRG Energy Center San Diego LLC

Rohr Inc, a UTC Aerospace Systems Company: UTAS Aerostructures

California Institute of Technology: California Institute-Technology

Caltech Central: Bloom Energy 2009 PPA

Alon Israel Oil Company Ltd, Paramount

Haynes: Los Angeles Department of Water and Power

AES Alamitos LLC: AES Alamitos LLC

Watkins Manufacturing Co.: Watkins Manufacturing Corporation

Miramar Energy Facility: San Diego Gas and Electric Co

North Island Energy Facility: Applied Energy Inc

Kaiser Downey: Bloom Energy 2009 PPA

Civic Center: Los Angeles County

P Plant: Qualcomm Incorporated

NTC/MCRD Energy Facility: Applied Energy Inc

Reid Gardner: Nevada Power Co

Glenarm: City of Pasadena - (CA)

Commerce Refuse To Energy: Los Angeles County Sanitation

Q Plant: Qualcomm Incorporated

W Plant: Qualcomm Incorporated

Chula Vista Energy Center: Wellhead Energy, LLC

Larkspur Energy Facility: Diamond Generating Corporation

Los Angeles County, CA
FCEV

NG Electricity Generators

NG Electricity Generators

NG Electricity Generators

NG Electricity Generators

NG Electricity Generators

NG Electricity Generators

NG Electricity Generators

NG Electricity Generators

NG Electricity Generators

NG Electricity Generators

Refinery

NG Electricity Generators

NG Electricity Generators

NG Electricity Generators

NG Electricity Generators

NG Electricity Generators

NG Electricity Generators

NG Electricity Generators

NG Electricity Generators

NG Electricity Generators

NG Electricity Generators

NG Electricity Generators

NG Electricity Generators

NG Electricity Generators

NG Electricity Generators

NG Electricity Generators

NG Electricity Generators

FCEV

2.74

13.76

0.31

2.74

329

3.38

0.31

3.38

0.79

0.18

0.79

0.18

4.78

4.78

0.02

0.02

$0.16 \quad 0.16$

$0.82 \quad 0.82$

$0.04 \quad 0.04$

$39.64 \quad 50.22$

$16.12 \quad 16.12$

$7.48 \quad 7.48$

$0.05 \quad 0.05$

$0.83 \quad 0.83$

$2.21 \quad 2.21$

$0.04 \quad 0.04$

$1.35 \quad 1.35$

$0.29 \quad 0.29$

$1.42 \quad 1.42$

$0.01 \quad 0.01$

$0.63 \quad 0.63$

$0.08 \quad 0.08$

$0.26 \quad 0.26$

$0.26 \quad 0.26$

$0.04 \quad 0.04$

0.38

0.38

41.91 
Life Technologies Carlsbad: Bloom Energy

UCSD Fuel Cell Plant: BioFuels Point Loma LLC

University of California San Diego: University of California San

Diego

Malburg: Colorado Energy Management LLC

H. Gonzales: City of Vernon

Carson Cogeneration: Carson Cogeneration Co

CalPeak Power Border Peaker Plant: Calpeak Operating Services,

LLC

Pio Pico Energy Center: Pio Pico Energy Center LLC

World Oil Co, South Gate

Otay Mesa Generating Project: Otay Mesa Energy Center LLC

Pyramid: Tri-State G and T Assn, Inc

Tesoro Corp, Carson

Air Products Carson Hydrogen Plant

Watson Cogeneration: ARCO Products Co-Watson

South Bay Fuel Cell Plant: BioFuels Point Loma LLC

Richard J Donovan Correctional Facility: California Dept of

Corrections

Phillips 66 Company, Wilmington

Tesoro Corp, Wilmington

Valero Energy Corp, Wilmington Asphalt Plant

Tesoro Carson Refinery

Grayson: City of Glendale - (CA)

Equilon Los Angeles Refining: Tesoro Refining and Marketing Company

Valero Energy Corp, Wilmington Refinery

THUMS: THUMS Long Beach Company

Verizon-Torrance: Bloom Energy

Phillips 66 Los Angeles Refinery - Carson Plant

\begin{tabular}{|c|c|c|c|}
\hline NG Electricity Generators & 0.04 & 0.04 & 335 \\
\hline NG Electricity Generators & 0.07 & 0.07 & 335 \\
\hline NG Electricity Generators & 1.68 & 1.68 & 335 \\
\hline NG Electricity Generators & 4.18 & 4.18 & 336 \\
\hline NG Electricity Generators & 0.02 & 0.02 & 336 \\
\hline NG Electricity Generators & 0.03 & 0.03 & 336 \\
\hline NG Electricity Generators & 0.10 & 0.10 & 336 \\
\hline NG Electricity Generators & 1.26 & 1.26 & 336 \\
\hline Refinery & 3.99 & 5.05 & 337 \\
\hline NG Electricity Generators & 11.55 & 11.55 & 337 \\
\hline NG Electricity Generators & 0.24 & 0.24 & 338 \\
\hline Refinery & 126.29 & 160.00 & 338 \\
\hline Syngas: Hydrogen, SMR & - & 101.34 & 338 \\
\hline NG Electricity Generators & 22.95 & 22.95 & 338 \\
\hline NG Electricity Generators & 0.02 & 0.02 & 338 \\
\hline NG Electricity Generators & 0.12 & 0.12 & 338 \\
\hline Refinery & 65.21 & 82.62 & 339 \\
\hline Refinery & 44.52 & 56.40 & 339 \\
\hline Refinery & 2.96 & 3.74 & 339 \\
\hline Syngas: Hydrogen, SMR & - & 138.55 & 339 \\
\hline NG Electricity Generators & 0.87 & 0.87 & 340 \\
\hline NG Electricity Generators & 1.48 & 1.48 & 340 \\
\hline Refinery & 39.88 & 50.52 & 340 \\
\hline NG Electricity Generators & 2.77 & 2.77 & 340 \\
\hline NG Electricity Generators & 0.04 & 0.04 & 340 \\
\hline Syngas: Hydrogen, SMR & - & 38.40 & 341 \\
\hline
\end{tabular}


Air Products Wilmington Hydrogen Plant

Harbor Cogen: Harbor Cogeneration Co.

Long Beach Generation LLC: NRG El Segundo Operations Inc Pbf Energy Co LLC, Torrance

Southeast Resource Recovery: SERRF Joint Powers Authority

Honda Torrance: Bloom Energy

McKinley County, NM

Lake One: City of Burbank Water and Power

Magnolia Power Project: City of Burbank Water and Power

Torrance Refining Company LLC

Phillips 66 Los Angeles Refinery - Wilmington Plant

Total Energy Facilities: Los Angeles County Sanitation

Los Angeles Refinery Wilmington: Phillips 66 - Los Angeles

Harbor: Los Angeles Department of Water and Power

AES Redondo Beach LLC: AES Redondo Beach LLC

El Segundo Cogen: Chevron USA Inc-El Segundo

CBS Studio Center: Crestmark Bank

Chevron Products, El Segundo Refinery

Chevron Corp, El Segundo

Saint Johns Health Center: Saint John's Health Center

UCLA So Campus Cogen Project: University of California-LA

Valley (CA): Los Angeles Department of Water and Power

Air Liquid Large Industries Us, Lp

Central Utilities Plant LAX 2: LAX Airport

Encina Water Pollution Control: Encina Joint Powers Authority

SEGS IV: FPL Energy Operating Services Inc - SEGS

SEGS III: FPL Energy Operating Services Inc - SEGS

SEGS V: FPL Energy Operating Services Inc - SEGS

Hyperion Treatment Plant CHP Plant: Constellation New Energy Inc.
Syngas: Hydrogen, SMR

NG Electricity Generators

NG Electricity Generators

Refinery

NG Electricity Generators

NG Electricity Generators FCEV

NG Electricity Generators

NG Electricity Generators

Syngas: Hydrogen, SMR

Syngas: Hydrogen, SMR

NG Electricity Generators

NG Electricity Generators

NG Electricity Generators

NG Electricity Generators

NG Electricity Generators

NG Electricity Generators

Syngas: Hydrogen, SMR

Refinery

NG Electricity Generators

NG Electricity Generators

NG Electricity Generators

Syngas: Hydrogen, SMR

NG Electricity Generators

NG Electricity Generators

NG Electricity Generators

NG Electricity Generators

NG Electricity Generators

NG Electricity Generators

\begin{tabular}{|c|c|c|}
\hline - & 88.24 & 341 \\
\hline 0.01 & 0.01 & 341 \\
\hline 0.40 & 0.40 & 341 \\
\hline 70.79 & 89.69 & 342 \\
\hline 0.26 & 0.26 & 342 \\
\hline 0.04 & 0.04 & 342 \\
\hline- & 0.00 & 343 \\
\hline 0.12 & 0.12 & 343 \\
\hline 7.67 & 7.67 & 343 \\
\hline- & 136.21 & 343 \\
\hline- & 61.46 & 345 \\
\hline 0.07 & 0.07 & 345 \\
\hline 1.12 & 1.12 & 345 \\
\hline 0.71 & 0.71 & 345 \\
\hline 4.73 & 4.73 & 346 \\
\hline 11.79 & 11.79 & 347 \\
\hline 0.06 & 0.06 & 348 \\
\hline- & 64.85 & 348 \\
\hline 126.20 & 159.88 & 348 \\
\hline 0.00 & 0.00 & 349 \\
\hline 2.75 & 2.75 & 349 \\
\hline 8.27 & 8.27 & 350 \\
\hline- & 87.68 & 350 \\
\hline 0.27 & 0.27 & 350 \\
\hline 0.01 & 0.01 & 350 \\
\hline 0.01 & 0.01 & 351 \\
\hline 0.01 & 0.01 & 351 \\
\hline 0.11 & 0.11 & 351 \\
\hline 0.08 & 0.08 & 351 \\
\hline
\end{tabular}


SEGS VI: FPL Energy Operating Services Inc - SEGS

SEGS VII: FPL Energy Operating Services Inc - SEGS

Scattergood: Los Angeles Department of Water and Power

El Segundo Energy Center LLC: NRG El Segundo Operations Inc

Western Refining Inc., Gallup

Olive View Medical Center: Los Angeles County

US Borax: U S Borax Inc

CSU Northridge Plant: California State University, Northridge

Berry Placerita Cogen: Berry Petroleum Co

Nye County, NV

Catron County, NM

SEGS IX: FPL Energy Operating Services Inc - SEGS

SEGS VIII: FPL Energy Operating Services Inc - SEGS

Grant County, NM

Pitchess Cogen Station: Los Angeles County

Escalante: Tri-State $\mathrm{G}$ and $\mathrm{T}$ Assn, Inc

Chino Mines: FreePort-McMoRan-Corp-Chino Mines

Luna Energy Facility: Public Service Co of NM

Ventura County, CA

CSUCI Site Authority: CSUCI Site Authority

Luna County, NM

Kane County, UT

Houweling Nurseries: Houweling's Tomatoes

E F Oxnard Energy Facility: EF Oxnard, LLC

Oxnard: Procter\&Gamble Paper Products Co-Oxnard

Oxnard Paper Mill: New-Indy, Oxnard LLC

Ormond Beach: NRG California South LP

Oxnard Wastewater Treatment Plant: Oxnard City of
NG Electricity Generators

NG Electricity Generators

NG Electricity Generators

NG Electricity Generators

Refinery

NG Electricity Generators

NG Electricity Generators

NG Electricity Generators

NG Electricity Generators

FCEV

FCEV

NG Electricity Generators

NG Electricity Generators

FCEV

NG Electricity Generators

NG Electricity Generators

NG Electricity Generators

NG Electricity Generators

FCEV

NG Electricity Generators

FCEV

FCEV

NG Electricity Generators

NG Electricity Generators

NG Electricity Generators

NG Electricity Generators

NG Electricity Generators

NG Electricity Generators

$\begin{array}{lll}0.10 & 0.10 & 352 \\ 0.11 & 0.11 & 352 \\ 10.82 & 10.82 & 352 \\ 8.20 & 8.20 & 352 \\ 7.82 & 9.90 & 354 \\ 0.24 & 0.24 & 355 \\ 2.97 & 2.97 & 360 \\ 0.05 & 0.05 & 362 \\ 2.80 & 2.80 & 363 \\ - & 0.22 & 364 \\ - & 0.00 & 370 \\ 0.20 & 0.20 & 370 \\ 0.22 & 0.22 & 371 \\ - & 0.00 & 372 \\ 1.34 & 1.34 & 372 \\ 0.07 & 0.07 & 383 \\ 0.01 & 0.01 & 384 \\ 14.01 & 14.01 & 386 \\ - & 3.52 & 387 \\ 1.12 & 1.12 & 387 \\ - & 0.00 & 389 \\ - & 0.00 & 390 \\ 0.49 & 0.49 & 391 \\ 1.11 & 1.11 & 395 \\ 3.72 & 3.72 & 395 \\ 1.64 & 1.64 & 398 \\ 2.07 & 2.07 & 398 \\ 0.01 & 0.01 & 398 \\ & & \end{array}$




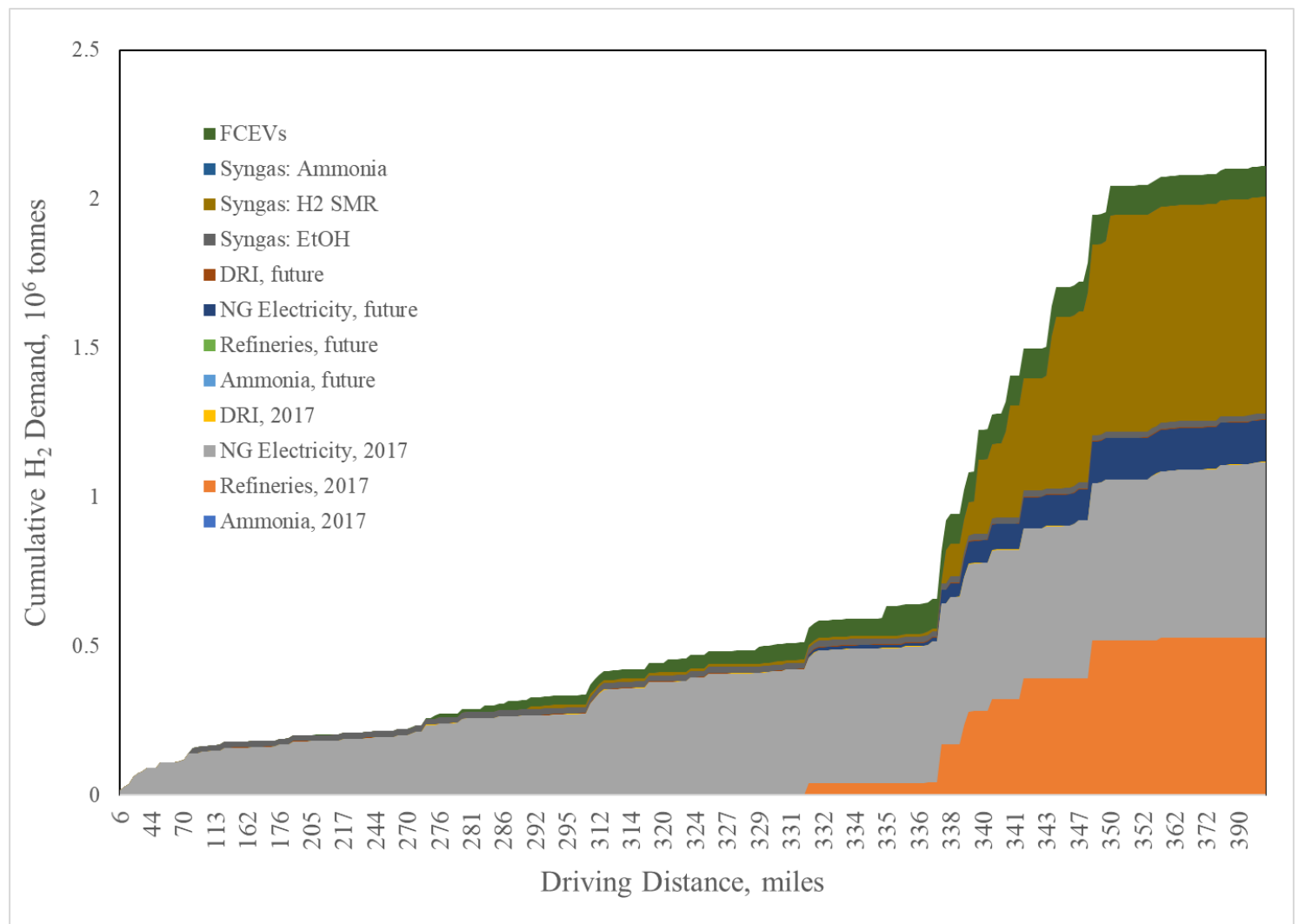

Figure 46. Cumulative potential hydrogen demand by type and distance near the Palo Verde generating station.

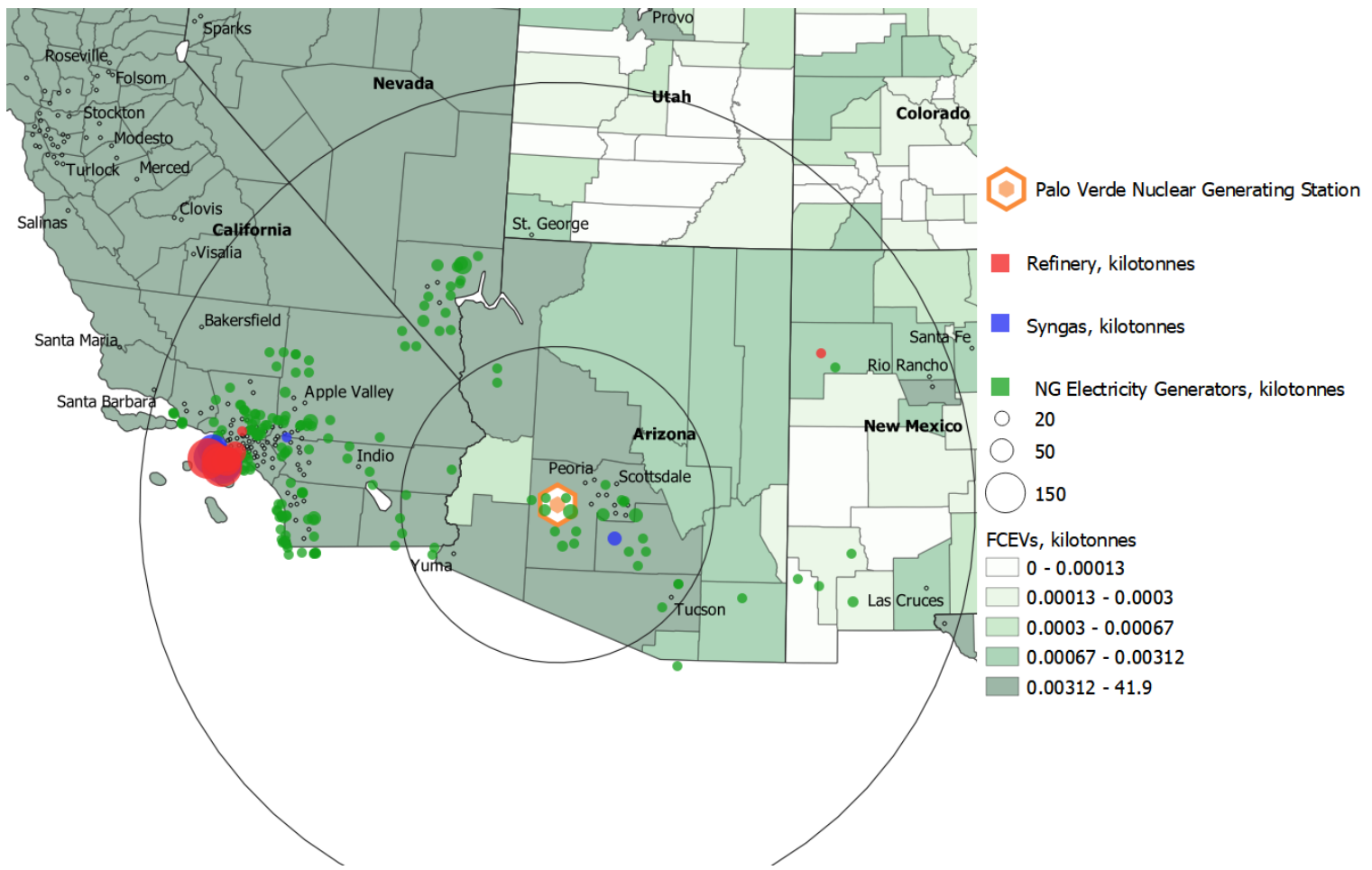

Figure 47. Future potential hydrogen demand near the Palo Verde generating station. 


\subsection{North / South Carolina Region}

This region includes three NPPs, Oconee, Catawba, and McGuire, producing nearly $7 \mathrm{GW}$ of electricity. Within 100 miles, these plants have no ammonia plants, but two plants, requiring $\sim 300 \mathrm{MT} /$ day $\mathrm{H}_{2}$ fall just outside the 100-mile radius. In addition, there are four steel mills requiring roughly 3,000 MT/day $\mathrm{O}_{2}$, although only one of these, in Charlotte, North Carolina, is particularly convenient to a nuclear facility. North and South Carolina have regulated retail electricity markets, meaning there is no available capacity market for alternative NPP revenue streams.

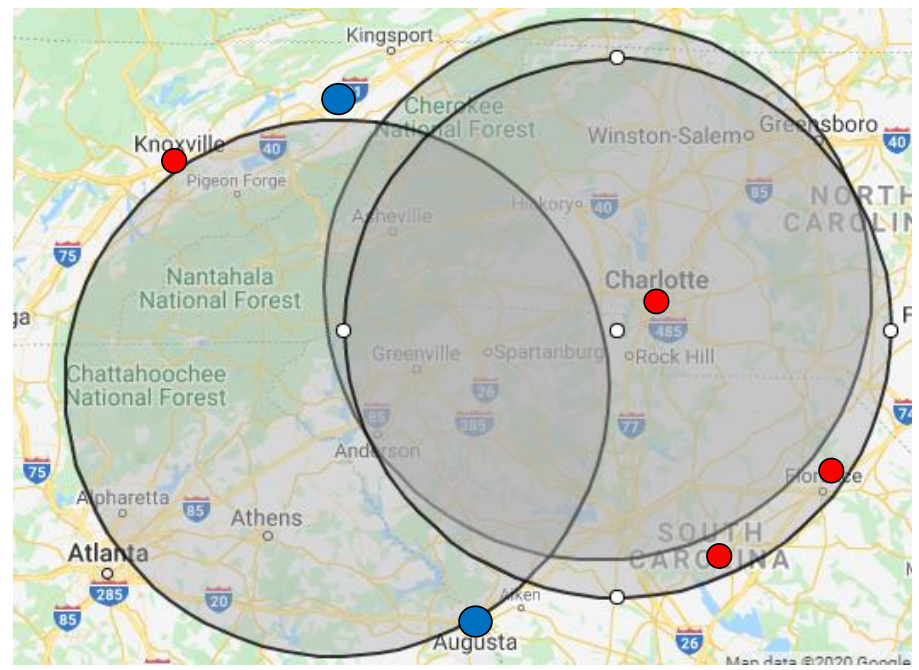

Figure 48. Location of ammonia plants (blue) and steel mills (red) within 100 miles of the NPP facilities in North and South Carolina.

\subsection{New York Region}

This region includes three NPPs, Ginna, James Fitzpatrick, and Nine Mile Point, totaling 3.1 GW of electricity generation. This region lacks significant point-source demand, with no ammonia plants or oil refineries, and only two steel mills requiring $400 \mathrm{MT} /$ day $\mathrm{O}_{2}$. NPP-electrolysis facilities in this region would need to cultivate new demand sources or incur significant transportation costs to be economically viable.

In the electricity markets, these facilities are located in the NY-ISO region. Results from recent capacity auctions suggest a typical price of \$43/MW-day in the hotter summer months, but only \$5/MWday in the colder winter months, suggesting an average price of $\$ 24 / \mathrm{MW}$-day for the year. However, only 3-4 GW appear to be accepted in the capacity market during each auction, casting doubt on whether all $3.1 \mathrm{GW}$ of NPP electricity would be eligible for capacity payments ${ }^{101}$. 


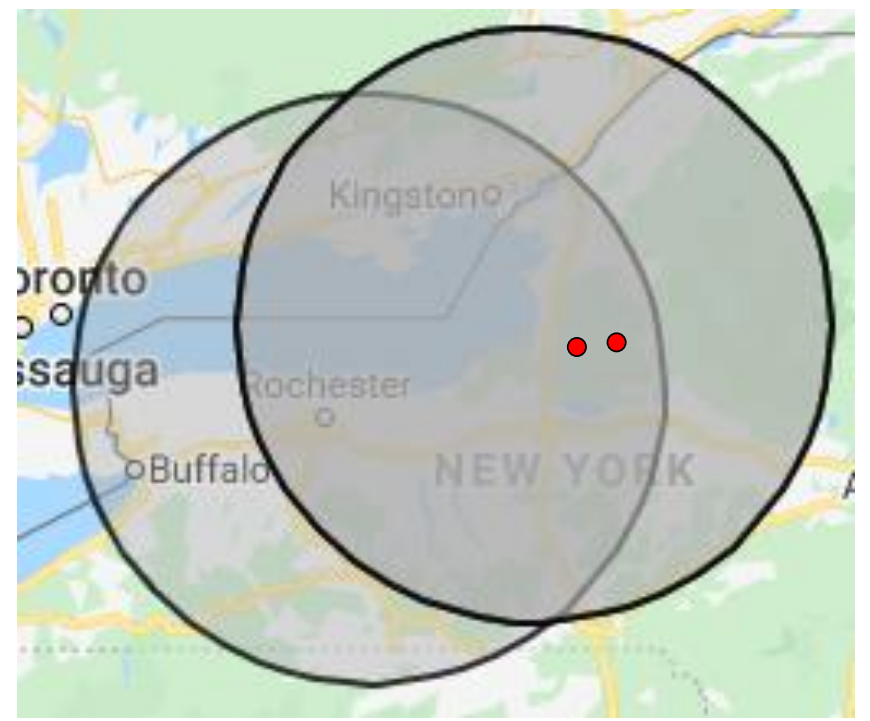

Figure 49. Location of steel mills (red) within 100 miles of the NPP facilities in New York. Large shaded filled circles are drawn to indicate a 100 radius around each NPP.

\subsection{Mid-Northeastern Region}

This region includes four NPPs (Salem, New Jersey, Limerick and Peach Bottom-East, Pennsylvania, and Calvert Cliffs, Maryland) producing 8.5 GW of electricity (see Figure 50. Location of oil refineries (purple) and steel mills (red) within 100 miles of the NPP facilities in the Mid-Atlantic US.). Although there are no nearby ammonia plants, this region does contain significant hydrogen and oxygen demand point-sources, including:

- Six oil refineries, totaling $\sim 1,000 \mathrm{MT} /$ day $\mathrm{H}_{2}$

- Seven steel mills, totaling $\sim 5,500 \mathrm{MT} /$ day $\mathrm{O}_{2}$.

The Philadelphia area contains four oil-refining facilities, generating products for both domestic use and export. These refineries would represent a critical demand source for SOEC plants at the Salem, Limerick, and Peach Bottom NPPs. Additionally, a fraction of the generated oxygen, totaling $\sim 5,500 \mathrm{MT} / \mathrm{day}$, could be sold to local steel mills.

In terms of the electricity markets, these facilities are located within the PJM market. Although the future of capacity markets within PJM is uncertain, previous analyses have used a value of \$132/MW-day to project future capacity payments based on prior year results. 


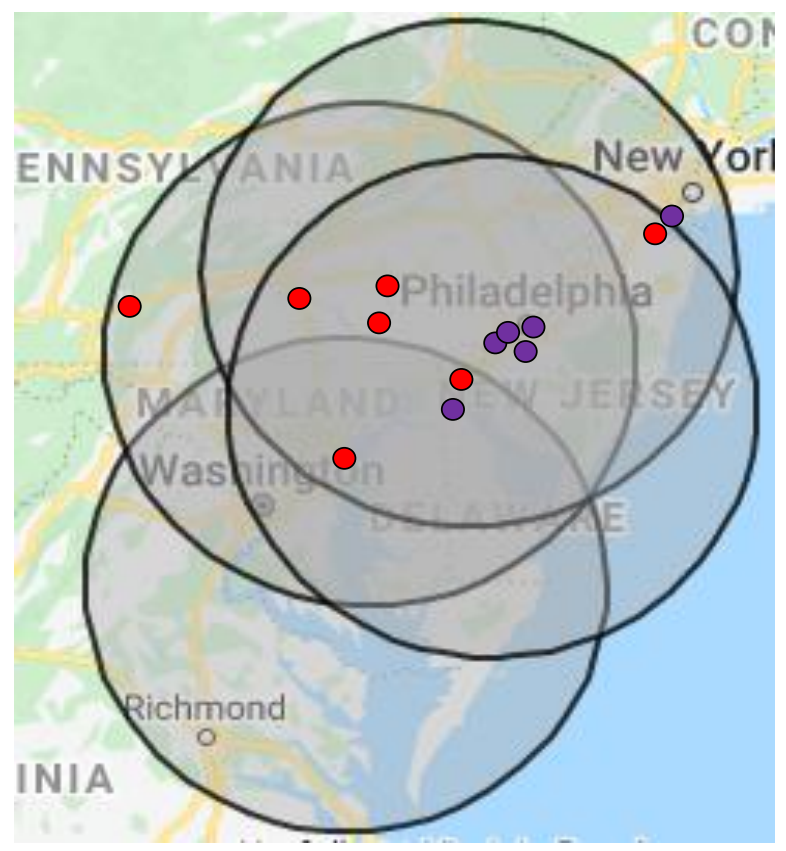

Figure 50. Location of oil refineries (purple) and steel mills (red) within 100 miles of the NPP facilities in the Mid-Atlantic US. 


\section{GENERALIZED SAMPLE ECONOMIC ANALYSIS OF HYDROGEN PRODUCTION COUPLED WITH NUCLEAR ENERGY IN A REGULATED MARKET}

This analysis represents a sample analysis using hydrogen market-demand data presented in this report for the Minnesota region. The purpose of this analysis is not to give an exhaustive analysis into hybrid energy systems evaluation but to provide to U.S. NPP operators an example of how a nonelectric product such as hydrogen can be coupled to form a hybrid nuclear-hydrogen integrated energy system that can access local markets, be a viable positive investment under certain conditions, and be competitive the incumbent production process (SMR, in this example). Such an investment would enable the production of green hydrogen from a low-carbon and low-emissions source that may also have premium marketability in markets where a carbon-credit tax system becomes reality.

HTSE is selected as the method of hydrogen production in this example because it provides the ability to increase the electrical efficiency of the water electrolysis process by close coupling both steam and electricity from the NPP. The hybrid NPP-HTSE plant is setup to provide a constant stream of hydrogen to a hypothetical end user. However, during peak demand, electricity is redirected from the HTSE and sold back to the grid. This essentially allows the NPP-HTSE plant to operate as reserve capacity, similar to a large-scale battery. During this time, previously stored hydrogen is provided to the customer to ensure a constant supply. As a result, a trade-off exists between the 1) stored capacity of hydrogen, 2) size of the HTSE plant, and 3) price of peak electricity. The final product of this study is a parametric evaluation of these different market conditions and component specifications. This will inform potentially interested parties on the key dynamics affecting the economic viabilities of NPP-HTSE hydrogen production.

Main assumptions will first be discussed. These have a large impact on the overall viability of a project and should be reevaluated on a case-by-case basis. Next, an overview of the simplified cost estimates, including capital cost (CAPEX), is provided. The overall benefit and costs to the grid are then estimated for a regulated market using simplified assumptions in lieu of complex grid-level analysis ${ }^{102}$.

The second stage of the analysis considers two hydrogen market conditions: (1) fixed price and (2) dynamic market response. In the first instance, hydrogen price is assumed to be fixed irrespective of the overall demand being serviced. In the second case, competition with an SMR plant is assumed. In this instance, the SMR sets the market price for hydrogen for a given demand size. Finally, sensitivity analyses are provided for potential carbon-tax impacts and variables that are strongly case-dependent.

\subsection{Economic-Model Development}

This economic analysis relies heavily on the evaluations conducted in INL/EXT-19-55395, Evaluation of Hydrogen Production Feasibility for a Light Water Reactor in the Midwest ${ }^{102}$. The approach is simplified for this analysis (i.e., no stochastic optimization is performed). While the previous study focused on a deregulated electricity market, this analysis of the Minnesota region will consider a regulated market. The main differences relate to the selling price of electricity being driven directly by NPP operation and maintenance (O\&M) costs, rather than being determined by the market. In addition, a fixed capacity payment is received for operating the plant partially as an electricity reserve (when electricity is redirected from the electrolyzer to the grid).

\subsubsection{Key Assumptions}

Parameters taken into account in this analysis are grouped as floating variables, which can be optimized (e.g., the size of the HTSE), fixed parameters (e.g., HTSE O\&M costs), estimated parameters for which a range is provided (e.g., $\mathrm{H}_{2}$ demand distance), and key results that are derived as part of the analysis (e.g., $\mathrm{H}_{2}$ daily production rate, HTSE overcapacity, and HTSE CAPEX). The price of hydrogen, 
as mentioned, will be: 1) set at a fixed price and 2) estimated based on market-price competition with an SMR plant.

To account for uncertainty and variability in different locations, an estimated range of low, base, and high is considered, with some parameters to quantify their impact, as summarized in Table 17 . The analysis first assumes the base values and then the low and high values individually in later sections to assess their impact on overall profitability.

Table 17. Estimated range defined for some specific parameters.

\begin{tabular}{|l|c|c|c|}
\hline Parameter & Low & Base & High \\
\hline Weighted average cost of capital & $5 \%$ & $7.5 \%$ & $10 \%$ \\
\hline Reserve capacity costs $(\$ / \mathrm{kW} /$ year) & $\$ 1 / \mathrm{kW} /$ year & $\$ 5 / \mathrm{kW} /$ year & $\$ 10 / \mathrm{kW} /$ year \\
\hline Peak electricity payment $(\$ / \mathrm{MWh})$ & $\$ 25 / \mathrm{MWh}$ & $\$ 50 / \mathrm{MWh}$ & $\$ 100 / \mathrm{MWh}$ \\
\hline $\mathrm{H}_{2}$ demand distance (miles) & 20 & 30 & 40 \\
\hline
\end{tabular}

Fixed parameter specifications are summarized in Table 18, along with a reference source. A standard pressurized water reactor (PWR) is assumed for the analysis. The NPP O\&M costs are assumed to be $\$ 20 / \mathrm{MWh}$. While this is below the currently reported rates of some NPPs, other NPPs are approaching or already under this cost while others in the industry are setting aggressive short-term cost targets in this range in order to remain competitive. Electricity peaks are assumed to last for around 2.4 hours and to occur at an average every two days. This translates to 2.4 hours of hydrogen storage needed, and a distance between electricity demand peaks (i.e., the time available to replenish the hydrogen storage) of 45.6 hours. HTSE specifications are all based on INL/EXT-19-55395 ${ }^{102}$. Note that updates to previously published assumptions, such as capacity replacement costs, were made following an internal review. Capacity replacement costs are based on online values provided by the National Renewable Energy Laboratory (NREL) ${ }^{103}$. The depreciation rate selected is standard for assets with comparable lifetimes to HTSE. The federal corporate tax is the post-2019 rate in the U.S. while the state corporate tax is an approximation based the on markets considered relevant to the study.

Table 18. Specifications selected for the fixed parameters.

\begin{tabular}{|c|c|c|}
\hline NPP O\&M costs & $\$ 20 / \mathrm{MW}_{\mathrm{e}} \mathrm{h}$ & Internal INL assessment. \\
\hline $\mathrm{H}_{2}$ storage time & $2.4 \mathrm{~h}$ & Internal INL assessment \\
\hline $\begin{array}{l}\text { Time to } \\
\text { replenish storage }\end{array}$ & $45.6 \mathrm{~h}$ & Internal INL assessment \\
\hline NPP power & $\begin{array}{l}3411 \mathrm{MW}_{\mathrm{th}} / \\
1095 \mathrm{MW}_{\mathrm{e}} \\
\end{array}$ & Westinghouse 4-loop ${ }^{104}$ \\
\hline HTSE efficiency & $\begin{array}{l}37.70 \\
\mathrm{~kW} \text { eh/kg- } \mathrm{H}_{2}\end{array}$ & INL/EXT-19-55395 ${ }^{102}$ \\
\hline $\begin{array}{l}\text { Steam/Electricity } \\
\text { ratio }\end{array}$ & $17.11 \%$ & INL/EXT-19-55395 ${ }^{102}$ \\
\hline $\begin{array}{l}\text { HTSE capacity } \\
\text { factor }\end{array}$ & $92 \%$ & $\begin{array}{l}\text { Based on NPP Capacity } \\
\text { Factor }\end{array}$ \\
\hline $\begin{array}{l}\text { HTSE O\&M } \\
\text { costs }\end{array}$ & $\$ 8.88 / \mathrm{MW}_{\mathrm{e}} \mathrm{h}$ & INL/EXT-19-55395 ${ }^{102}$ \\
\hline $\mathrm{H}_{2}$ storage costs & $\$ 600 / \mathrm{kg}-\mathrm{H}_{2}$ & INL/EXT-19-55395 ${ }^{102}$ \\
\hline $\begin{array}{l}\mathrm{H}_{2} \text { transportation } \\
\text { costs }\end{array}$ & $\$ 996,492 /$ mile & INL/EXT-19-55395 102 \\
\hline
\end{tabular}




\begin{tabular}{|l|l|l|}
\hline $\begin{array}{l}\text { Hot standby } \\
\text { electric load }\end{array}$ & $10 \%$ & INL/EXT-19-55395 $^{102}$ \\
\hline $\begin{array}{l}\text { Steam hot } \\
\text { standby }\end{array}$ & $100 \%$ & INL/EXT-19-55395 $^{102}$ \\
\hline $\begin{array}{l}\text { HTSE } \\
\text { construction } \\
\text { time }\end{array}$ & 3 years & Internal INL assessment. \\
\hline HTSE lifetime & 20 years & Internal INL assessment $^{\text {Alternate O\&M }}$ \\
costs & $\$ 36.4 / \mathrm{MWh}$ & NREL $^{103}$ \\
\hline $\begin{array}{l}\text { Alternate } \\
\text { CAPEX }\end{array}$ & $\$ 898 /$ Kw & NREL $^{103}$ \\
\hline $\begin{array}{l}\text { Depreciation rate } \\
\text { MACRS 15- } \\
\text { year property } \\
\text { class }\end{array}$ & - \\
\hline $\begin{array}{l}\text { MN state } \\
\text { corporate tax }\end{array}$ & $9.8 \%$ & - \\
\hline $\begin{array}{l}\text { Federal } \\
\text { corporate tax }\end{array}$ & $21 \%$ & - \\
\hline
\end{tabular}

\subsubsection{Base Case Development}

The size of the hydrogen plant is determined by its electrical energy consumption. Initially, a hypothetical $100 \mathrm{MW}_{\mathrm{e}}$ plant was considered as a base case; later in this report sensitivity studies on the plant size are presented. For the base case, thermal energy of $17 \mathrm{MW}_{\text {th }}$ is required in steam supply, which corresponds to a steam/electricity ratio of 0.17 .

The rate of hydrogen production depends on the system efficiency. Assuming a value of $37 \mathrm{~kW} / \mathrm{h} / \mathrm{kg}$ $\mathrm{H}_{2}$, a $100 \mathrm{MW}_{\mathrm{e}} \mathrm{HTSE}$ plant would produce a maximum theoretical output of $2,652 \mathrm{~kg}-\mathrm{H}_{2} / \mathrm{h}$. Assuming that both the HTSE and the NPP have a capacity factor of $92 \%$ and that $5 \%$ of the hydrogen produced goes to storage (this is equivalent to 2.4 hours of storage capacity dispatched every 48 hours). The daily average output would be $2,318 \mathrm{~kg}-\mathrm{H}_{2} /$ hour, corresponding to a total output of around 20 kilotonnes$\mathrm{H}_{2} /$ year. These different values, which are based on the $100 \mathrm{MW}_{\mathrm{e}}$ base case assumption, along with the fixed parameters in Table 18, are summarized in Table 19. Later sections will investigate the interdependence of HTSE size and hydrogen selling price in further detail. 
Table 19. Summary of base case values.

\begin{tabular}{|l|l|}
\hline & \\
\hline HTSE thermal consumption & $17 \mathrm{MWth}$ \\
\hline Storage fraction & $5 \%$ (corresponds to $2.4 \mathrm{~h} / 48 \mathrm{~h})$ \\
\hline Nominal hourly output & $2,652 \mathrm{~kg}-\mathrm{H} 2 / \mathrm{h}$ \\
\hline Yearly output & $20.3 \mathrm{kilotonnes}-\mathrm{H} 2 /$ year \\
\hline Storage capacity & $6,047 \mathrm{~kg}-\mathrm{H} 2$ \\
\hline Storage feed rate & $122 \mathrm{~kg}-\mathrm{H} 2 / \mathrm{h}$ \\
\hline Storage capacity & $6,047 \mathrm{~kg}-\mathrm{H} 2$ \\
\hline Assumed H2 selling price & $\$ 1.8 / \mathrm{kg}-\mathrm{H} 2$ (revisited in later sections) \\
\hline
\end{tabular}

\subsubsection{Cost Estimation}

\subsubsection{HTSE capital costs}

HTSE plant CAPEX costs are based on INL/EXT-19-55395 ${ }^{102}$, with some updates, as noted:

- CAPEX are categorized and scaled as either "conventional" or "modular" system components

- Nth-of-a-kind HTSE plant construction is assumed in lieu of first-of-a-kind plant construction

- Revised indirect capital cost factors reflect cost savings associated with modular plant construction.

Conventional components include equipment that scales with plant capacity (i.e., the heat exchangers and piping associated with the nuclear process-heat delivery equipment). Modular components include equipment that is installed in parallel to achieve increased plant capacity (i.e., multiple identical HTSE modules, each having the same equipment specifications and production capacity are operated together to achieve the required hydrogen production). Capital-cost savings for the modular equipment are achieved through economies of mass production while capital-cost savings for conventional equipment are achieved through economies of scale.

The HTSE plant total direct capital cost (DCC) was determined by summing the conventional and modular equipment costs (Equation 1). The equipment in each of these CAPEX categories scales with plant capacity according to a different scaling exponent.

$D C C=C A P E X_{\text {conventional }}+C A P E X_{\text {modular }}$

Equation 1

\section{Conventional CAPEX Equipment Calculation}

The conventional equipment capital cost scaling factor was determined by evaluating the capital costs of each conventional-equipment component (heat exchangers, pumps, pipes, etc.) over a range of equipment sizes (corresponding to different HTSE plant capacities), and curve fitting the resulting total conventional equipment capital cost versus plant-capacity data. Aspen Process Economic Analyzer was used to estimate the equipment capital costs at each of the specified equipment sizes. The conventional equipment cost for a $25 \mathrm{MW}_{\mathrm{e}}$ HTSE unit was estimated at $\$ 2.22 \mathrm{M}$ and vary with plant capacity according to a scaling exponent of 0.571 (Equation 2). For a $100 \mathrm{MW}_{\mathrm{e}}$ plant, this corresponds to conventional costs of around $\$ 5 \mathrm{M}$.

CAPEX $X_{\text {conventional }}=\$ 2.22 \times 10^{6}\left(\frac{P_{H T S E}}{25 M W_{e}}\right)^{0.571}$

Equation 2

\section{Modular CAPEX Equipment Calculation}

Modular equipment costs were calculated from several sources, including SOEC-manufacturer cost estimates for specialty components such as the SOEC stacks, and Aspen Process Economic Analyzer cost 
estimates for modular balance-of-plant equipment such as heat exchangers, pumps, vessels, etc. Modular equipment costs were estimated for an HTSE module with $25 \mathrm{MW}_{\mathrm{e}}$ hydrogen-production capacity, and a learning curve relationship was used to determine modular component costs for both first-of-a-kind (FOAK) as well as Nth-of-a-kind (NOAK) plant construction.

FOAK construction was assumed in the analysis presented in report INL/EXT-19-55395. For FOAK plant construction, the costs of each module are assumed to decrease in accordance with a learning curve, and the total modular-component capital costs are the cumulative sum of the capital costs for each modular unit. For the case of an FOAK plant, the capital costs for the first $25 \mathrm{MW}_{\mathrm{e}}$ module were estimated as $\$ 10.3 \mathrm{M}$. A scaling exponent of 0.936 provides a fit of the cumulative modular equipment costs for the case of a 95\% learning curve (Equation 3).

$C A P E X_{\text {modular }, F O A K}=\$ 10.3 \times 10^{6}\left(\frac{P_{H T S E}}{25 M W_{e}}\right)^{0.936}$

Equation 3

For NOAK plant construction, the modular-component capital costs are assumed to scale linearly with plant capacity because the learning-curve effects are negligible for an NOAK plant (Equation 4) i.e., the learning curve is flat for a small batch of units positioned far from the origin (a large number of previous HTSE module installations, $\mathrm{N}$ ) on the curve. The learning rate determines the magnitude of the modular equipment cost reductions for an NOAK plant; in the current analysis, a 95\% learning rate was assumed. For the hypothetical plant size of $100 \mathrm{MW}_{\mathrm{e}}$, modular costs correspond to around $\$ 29 \mathrm{M}$.

$\begin{array}{ll}C A P E X_{\text {modular }, N O A K}=\$ 7.34 \times 10^{6}\left(\frac{P_{H T S E}}{25 M W_{e}}\right) & \text { Equation } 4\end{array}$

The current analysis also utilized indirect cost multipliers modified to reflect the cost savings associated with NOAK modular plant construction. The indirect-cost multipliers were specified as 5\% for site preparation $\left(\mathrm{F}_{\mathrm{SP}}\right), 2 \%$ for engineering and design $\left(\mathrm{F}_{\mathrm{E} \& \mathrm{D}}\right), 10 \%$ for project contingency $\left(\mathrm{F}_{\mathrm{CNTG}}\right), 3 \%$ for contractor's fee $\left(\mathrm{F}_{\mathrm{CNTR}}\right), 2 \%$ for legal fee $\left(\mathrm{F}_{\mathrm{LGL}}\right)$ and $1.5 \%$ for land cost $\left(\mathrm{F}_{\mathrm{LAND}}\right)$. The total depreciable capital costs (TDCC) are obtained by multiplying the DCC by the sum of the indirect depreciable cost multipliers (Equation 5).

$T D C C=D C C \cdot\left(1+F_{S P}+F_{E \& D}+F_{C N T G}+F_{C N T R}+F_{L G L}\right)$

Equation 5

The HTSE total capital investment is the product of the total depreciable capital costs and the nondepreciable capital cost multipliers (Equation 6).

$T C I=T D C C \cdot\left(1+F_{\text {land }}\right)$

Equation 6

For a NOAK $100 \mathrm{MW}_{\mathrm{e}}$ capacity HTSE plant, the total capital cost is therefore $\$ 42 \mathrm{M}$, or $\$ 424 / \mathrm{kW}_{\mathrm{e}}$. The construction time is assumed to be 3 years, and the lifetime of the plant is assumed to be 20 years.

\subsubsection{HTSE operating costs}

The HTSE operating costs (OPEX) are expressed as a function of the NPP plus some overhead (labor, maintenance, etc.). In a regulated electricity market, the energy costs are driven directly by the NPP O\&M. The assumed $\$ 20 / \mathrm{MW}_{\mathrm{e}} \mathrm{h}$ is for NPP O\&M with an additional $\$ 8.88 / \mathrm{MW}_{\mathrm{e}}$ h assumed for the HTSE plant O\&M.

\subsubsection{Hydrogen storage costs}

As described previously in this report, hydrogen storage costs are subdivided into two main components: storage vessel and compressor costs. The total stored capacity is expressed as a function of the number of hours during which electricity is diverted from the HTSE to the grid. For 2.4 hours of storage time, a $100 \mathrm{MW}_{\mathrm{e}}$ plant will need to store around $6 \mathrm{~T}-\mathrm{H}_{2}$. Following the costing algorithms previously presented, the vessel costs can be expressed as a function of stored capacity (in $\left.\mathrm{kg}-\mathrm{H}_{2}\right)$ while the compressor costs are expressed as a function of its required power $\left(P_{\text {comp }}\right)$ in kilowatts: 
CAPEX $X_{\text {vessel }}=\$ 600 \times$ capacity

Equation 7

CAPEX $X_{\text {comp }}=\$ 40,500 \times\left(P_{\text {comp }}\right)^{0.46}$

Equation 8

The storage and transportation costs are greatly impacted by different system pressures. The strategy identified by Yildiz et al. ${ }^{105}$ was employed in this analysis. The electrolysis feedwater was pumped to a pressure of $2 \mathrm{MPa}$ followed by additional compression of the hydrogen product to a pressure of $10 \mathrm{MPa}$ for pipeline transport or $20 \mathrm{MPa}$ for hydrogen storage. The hydrogen delivery pressure (the pressure at which hydrogen customers would receive hydrogen from the pipeline) was assumed to be equal to 3.5 MPa.

Compressor- and pump-equipment sizing were calculated based on correlations ${ }^{106}$. Separate compressors are needed for storage and transportation to pressurize the product hydrogen to the required conditions. The storage compressor pressurizes to a higher pressure than the transportation compressor, so the storage vessel can release into the lower transportation infrastructure without the need for additional compression.

For a 100 MWe HTSE plant with 45.6-hour storage ramp-rate time, the corresponding hydrogen flow rate to the storage tanks is around $0.03 \mathrm{~kg}-\mathrm{H}_{2} / \mathrm{second}$. Four compressor stages operating at $85 \%$ efficiency are assumed. With these specifications a total storage compressor power of $150 \mathrm{~kW}$ is needed. This corresponds to a total compressor cost of around $\$ 400 \mathrm{k}$. With vessel costs of around $\$ 3.6 \mathrm{M}$, the total storage CAPEX equates to $\$ 4.0 \mathrm{M}$ for the example base case.

\subsubsection{Hydrogen transportation costs}

Hydrogen transportation costs will depend on the distance between the NPP and the area of consumption. An initial distance of 30 miles is selected for the analysis. The cost correlations previously presented were used to estimate hydrogen compressor and pipeline costs. Compressor costs for transportation were based on their power requirements, similar to what was calculated for hydrogen storage. Pipeline costs are based on pipeline diameter and length. The calculated pipeline diameter was rounded up to the closest nominal diameter in order to calculate pipeline costs. The pipeline cost correlation includes contributions for materials, labor, right-of-way, and miscellaneous costs. 108 :

The Equation 9 can be used to calculate the inside diameter of a pipeline for liquid or gas transport ${ }^{107}$

$D_{i}=\left\{\frac{-64 Z_{\text {ave }}^{2} R^{2} T_{\text {ave }}^{2} f_{F} \dot{m}^{2} L}{\pi^{2}\left[M Z_{\text {ave }} R T_{\text {ave }}\left(p_{2}^{2}-p_{1}^{2}\right)+2 g P_{a v e}^{2} M^{2}\left(h_{2}-h_{1}\right)\right]}\right\}^{1 / 5}$

Equation 9

where $D_{i}$ is the internal pipeline diameter $(\mathrm{m}), Z_{\text {ave }}$ is the average fluid compressibility, $R$ is the universal gas constant $\left(\mathrm{Pa} \mathrm{m}^{3} / \mathrm{mol} \mathrm{K}\right), T_{\text {ave }}$ is the average fluid temperature $(\mathrm{K}), f_{F}$ is the Fanning friction factor, $\dot{m}$ is the design mass flow rate $(\mathrm{kg} / \mathrm{s}), L$ is the pipeline segment length $(\mathrm{m}), M$ is the molecular weight of the stream $(\mathrm{kg} / \mathrm{kmol}), g$ is acceleration due to gravity $\left(\mathrm{m} / \mathrm{s}^{2}\right), p$ is pressure $(\mathrm{Pa}), h$ is pipeline elevation $(\mathrm{m})$, where 1 and 2 represent upstream and downstream locations.

Pressure varies non-linearly in the pipeline and must be calculated using Equation $10^{107}$ :

$P_{\text {ave }}=\frac{2}{3}\left(p_{2}+p_{1}-\frac{p_{2} p_{1}}{p_{2}+p_{1}}\right)$

Equation 10

Zigrang and Sylvester ${ }^{109}$ provide an explicit approximation for the Fanning friction factor, presented as Equation 11:

$\frac{1}{2 \sqrt{f_{F}}}=-2.0 \log \left\{\frac{\varepsilon / D_{i}}{3.7}-\frac{5.02}{R e} \log \left[\frac{\varepsilon / D_{i}}{3.7}-\frac{5.02}{R e} \log \left(\frac{\varepsilon / D_{i}}{3.7}+\frac{13}{R e}\right)\right]\right\}$

Equation 11

where $\varepsilon$ is the roughness of the pipe (m), and Re is the Reynolds number (Equation 12): 
$R e=\frac{4 \dot{m}}{\mu \pi D_{i}}$

Equation 12

where $\mu$ is the viscosity of the fluid ( $\mathrm{Pa} \mathrm{s}$ ).

The Fanning friction factor is a function of the pipeline diameter and the Reynolds number and does not have a direct analytical solution. The Fanning friction factor must therefore be iteratively solved along with the pipeline diameter and Reynolds number.

The diameter of the pipeline used to transport the fluid is highly dependent on the fluid-transport conditions (temperature and pressure) and the resulting fluid properties. In this analysis, REFPROP v9.1 was used to calculate temperature- and pressure-dependent fluid properties.

Using the strategy of Yildiz et al. ${ }^{105}$, the $2 \mathrm{MPa}$ hydrogen product stream from the HTSE must be raised to $10 \mathrm{MPa}$ before injecting into the pipeline where the receiving end has a pressure of $3.5 \mathrm{MPa}$. For the selected example case, this corresponds to a pipeline diameter of $4 \mathrm{in}$. Assuming a single pipeline supplying customers along a 30-mile distance, the corresponding piping costs are broken down as follows:

- Material costs: $\$ 2.7 \mathrm{M}$

- Labor costs: $\$ 6.3 \mathrm{M}$

- Right of way costs: $\$ 5.4 \mathrm{M}$

- Miscellaneous costs: $\$ 5.9 \mathrm{M}$

- Total piping costs: $\$ 20.4 \mathrm{M}$.

This corresponds to piping costs of around $\$ 681 \mathrm{k} / \mathrm{mile}$. The compressor costs can then be estimated following a similar approach conducted for storage compression. For a $100 \mathrm{MWe}$ HTSE plant, the hydrogen-product output flowrate to the pipeline distribution system is approximately $0.7 \mathrm{~kg}-\mathrm{H}_{2} / \mathrm{sec}$. One compressor train with three stages, each operating at a compression ratio of 1.7 and $85 \%$ efficiency, are assumed. Using these specifications, the pipeline inlet-compressor power requirement is equal to $1.9 \mathrm{MW}_{\mathrm{e}}$ and the compressor capital costs are estimated as $\$ 1.3 \mathrm{M}$.

Therefore, for a $100 \mathrm{MW}_{\mathrm{e}}$ HTSE plant supplying users on a single pipeline 30 miles from the NPPHTSE plant, the total transportation costs are $\$ 21.7 \mathrm{M}$. It is expected that the resulting demand for the HTSE hydrogen would stem from more than one customer scattered around a 30-mile radius. Therefore, a sensitivity study on the piping length is considered at a later stage of the analysis.

\subsection{Economic Analysis Results}

\subsubsection{Single Fixed Hydrogen Price}

With all the different hydrogen-related cost and revenue streams accounted for, a cash-flow analysis can be conducted to provide a first-order estimate of plant viability. Hydrogen sale prices can depend on a wide range of factors. As previously stated, two alternative approaches will be used to estimate price ranges in later sections. To illustrate the calculation methodology, an assumed fixed price of $\$ 1.8 / \mathrm{kg}-\mathrm{H}_{2}$ is assumed at this stage. With hydrogen production over $20 \mathrm{kT}-\mathrm{H}_{2} /$ year, this corresponds to a revenue of \$36M/year. Equation 13

Assuming the MACRS 15-year property class for the depreciation schedule, the free cash flow to the firm (FCFF) can be computed by:

$F C F F=($ Revenue $-O \& M-$ Depreciation $) \times(1-$ tax $)+$ Depreciation - CAPEX $\quad$ Equation 13

where the tax rates of $9.8 \%$ and $21.0 \%$ are used for the state and federal level, respectively. Using a weighted average cost of capital (WACC) of 10\%, the net present value (NPV) can be computed by: 
$N P V=\sum_{y=1}^{N} \frac{F C F F}{(1+W A C C)^{y}}$

Equation 14

This results in an NPV of around $\$ 10 \mathrm{M}$ for the considered inputs in this section. It does not include indirect revenues or costs that are grid dependent. These will be considered in the following two subsections. The profitability index (PI) can be also computed as the ratio of cumulative weighted FCFF to the total capital expenditure. A PI value of $117 \%$ is obtained at this stage.

\subsubsection{Grid costs and benefits considerations in a regulated market}

An additional aspect to consider is the overall cost and benefit to the grid by operating the LWRHTSE hybrid plant such that it could supply electricity to the grid-electricity market as reserve capacity when needed in lieu of producing hydrogen. Hypothetically, there could be two key components to this:

1. Reserve capacity - electricity can be diverted from the HTSE to the grid during periods of high electricity demand. In essence, the original baseload capacity is converted to a reserve capacity. Currently, reserve capacities are more valuable to a grid with high penetration of variable energy sources (such as renewables). The NPP-HTSE plant may be able to receive a yearly capacity payment as a result of this conversion and create revenue from electricity sales during these demand peaks.

2. Lost capacity for hot standby operation - current HTSE designs require the HTSE to remain in hot standby when not being used in order to avoid very long startup times. The steam and electricity required for hot standby operation cannot be diverted to the grid during high grid demand. This lost capacity would need to be replaced on the grid by an alternative source of dispatchable electricity (typically a combine gas turbine). To maintain similar costs to the grid, the local regulator may require the NPP-HTSE plant to cover the cost of the allocated CAPEX of such alternative facility and the difference in OPEX costs between it and the original NPP O\&M.

Assuming that both of these components must be accounted for, the hot standby capacity of the HTSE must be computed. It is assumed that the HTSE requires $100 \%$ of its nominal heat intake and around $10 \%$ of its electrical consumption when in hot standby in order to maintain minimal operations and temperatures. This results in a $90 \mathrm{MW}_{\mathrm{e}}$ reserve capacity that can be fed back to the grid (Component 1), and 15.5 $\mathrm{MW}_{\mathrm{e}}$ in lost capacity that will need to be replaced with another source (Component 2). The gain from operating the reactor partially as a reserve is assumed to be $\$ 5 / \mathrm{kW} /$ year in terms of capacity, and $\$ 50 / \mathrm{MWh}$ in electricity sales. Assuming the HTSE will dispatch to the grid during 182 peaks of 2.4 hours each (corresponds to $5 \%$ overproduction), this provides an additional revenue of around $\$ 2.4 \mathrm{M} /$ year.

If the cost of replacing the $15.5 \mathrm{MW}_{\mathrm{e}}$ is considered lost capacity by the grid regulator, then this would incur a cost to the system. The standard capacity cost for an equivalent dispatchable source is taken as $\$ 898 / \mathrm{kW}$, which corresponds to a combined-cycle gas turbine, and the typical O\&M costs such a power source is $\$ 36 / \mathrm{MWh}^{103}$. This results in a total CAPEX cost of around $\$ 14 \mathrm{M}$, and a yearly O\&M costs of around $\$ 2 \mathrm{M} /$ year. Note that the original NPP O\&M costs are subtracted to obtain this number in order to maintain a similar cost to the grid in a regulated market. Future technological improvements that might limit the hot stand-by requirements could therefore contribute to important cost savings in the overall systems. For instance, if hot standby required $100 \%$ of steam input (difficult to vary), but only $5 \%$ of the electricity input, the CAPEX penalty and the yearly O\&M costs would be reduced by $32 \%$.

Accounting for all these effects together (with the assumed 10\% electricity diversion during hot standby), the NPV of the NPP-HTSE cogeneration plant would still be positive, at around \$786k, making it an attractive proposal. The overall profitability index is $101 \%$. Following a few iterations, it can also be determined that the average price of $\mathrm{H}_{2}$ sales must be at or above $\$ 1.795 / \mathrm{kg}-\mathrm{H}_{2}$ to ensure a positive NPV under the assumed conditions. 


\subsubsection{Hydrogen Contract Price at Five Fixed Price Tiers}

Hydrogen prices strongly impact the profitability of hydrogen production at the NPP. The long-term selling price will be negotiated with different buyers at a contract competitive market rate. The price will likely be locked down for the duration of the contract; hence, no time variability in selling prices is assumed in the analysis. Using the economic model developed, a parametric evaluation of hydrogen price and other metrics was performed to estimate their impact on overall plant profitability. Figure 51 plots the NPV as a function of HTSE size for different prices of hydrogen. The analysis assumes a fixed contract price of hydrogen set with the buyer. In reality, there will likely be a market response for the introduction of large quantities of hydrogen in the market. This first-order estimate is still a useful approach for elucidating the impact of the key variables of plant size and hydrogen price on the economics of hydrogen production via the NPP-HTSE plant.

\section{Fixed Hydrogen Price}

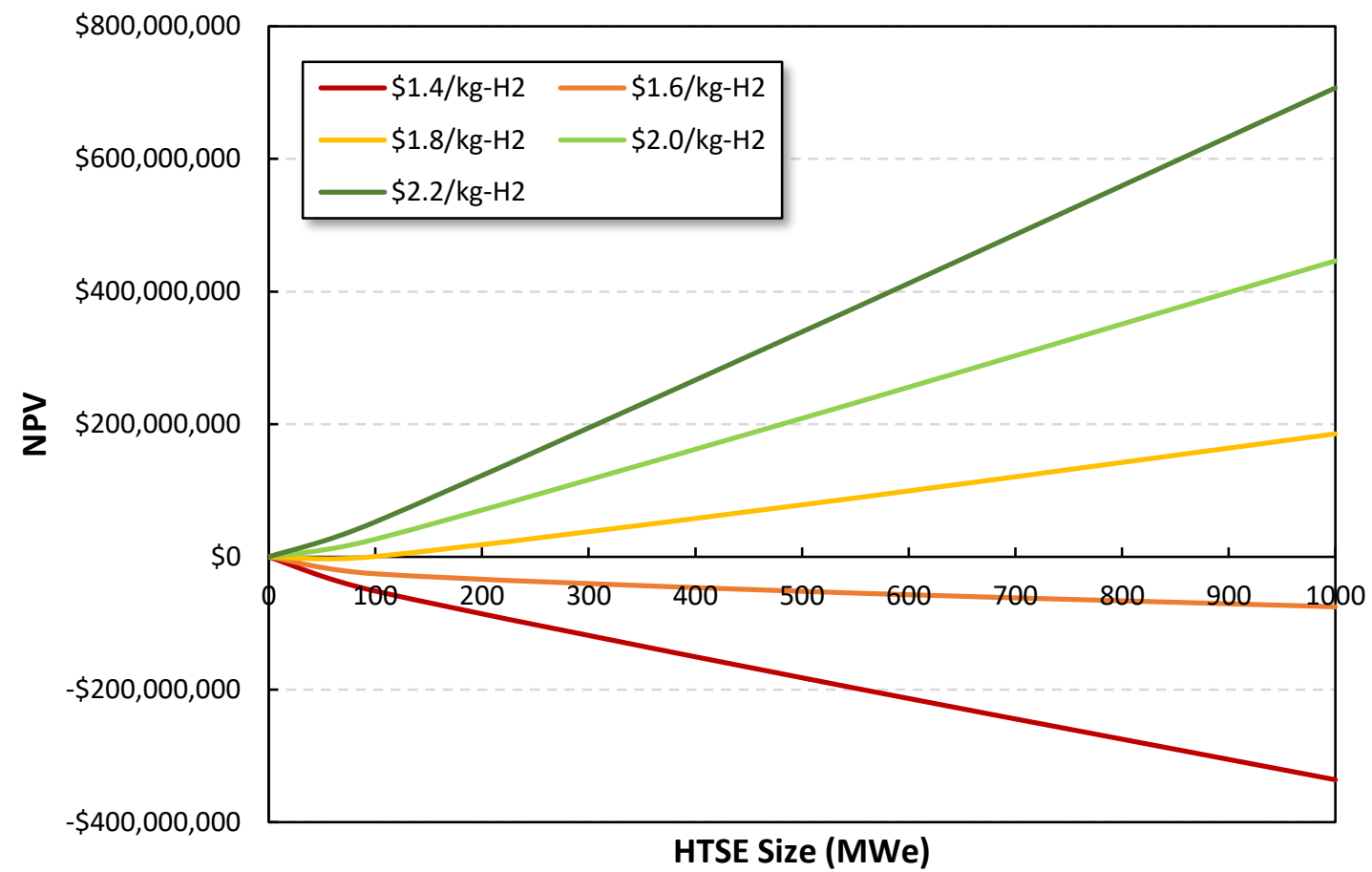

Figure 51. Impact of fixed hydrogen prices on the overall profitability of the system.

It is important to emphasize that all assumed parameters are held constant in this analysis (e.g., transportation distance, storage time, peak electricity payments). However, some level of feedback between these variables is likely in an actual deployment scenario. A complex grid-level simulation ${ }^{102}$, is needed to reach that level of fidelity. Nevertheless, Figure 51 provides a useful first order estimate for possibly viable sizes of NPP-HTSE hydrogen production with sample assumptions.

Under fixed hydrogen contract price conditions, profitability curves vary in a near-linear relation with HTSE size. As such, for price points that start out with a negative NPV (e.g., $\$ 1.6 / \mathrm{kg}-\mathrm{H}_{2}$ ), the losses are only exacerbated if the plant size is increased. However, at price points which start with a positive value (e.g., $\$ 1.8 / \mathrm{kg}-\mathrm{H}_{2}$ ) gains are compounded. Per this analysis and assumptions, to ensure a positive NPV under the assumed market conditions, the hydrogen contract sale price must be above $\$ 1.795 / \mathrm{kg}-\mathrm{H}_{2}$. A different type of behavior is observed under market response conditions, as will be discussed. 
Overall, assuming fixed hydrogen prices, it appears to be favorable to maximize the HTSE size under any positive NPV condition. However, this is not fully grounded in reality as it ignores potential competition. It is unlikely that the selling price of hydrogen for $100 \mathrm{MW}_{\mathrm{e}} \mathrm{HTSE}$ plant producing $20 \mathrm{kT}$ $\mathrm{H}_{2} /$ year will be the same as a $500 \mathrm{MW}_{\mathrm{e}}$ plant generating $100 \mathrm{kT}-\mathrm{H}_{2} /$ year. The main objective here is to illustrate the general trends available to operators considering hydrogen production at a given NPP.

\subsubsection{Dynamic Hydrogen Price Market Response}

The incumbent competitor to an NPP-HTSE hydrogen plant is NG SMR. As a result, the highest hydrogen price as a function of demand size will be determined by the economies of scale that an SMR plant can achieve. It should be noted, however, that the economics of NG plants are very different to those of an NPP-HTSE. While fuel costs are low for an NPP, they are the main contributor for an NG plant. While NG prices are currently very low, they have historically seen much variability. As a result, three conditions are considered in this subsection: (1) a medium gas price (similar to current market rates), (2) a low price, assuming gas prices drop further, and (3) a high NG price. Figure 52 plots the price of hydrogen as a function of demand for each of these three NG price conditions (as dictated by the cost of hydrogen production via SMR).

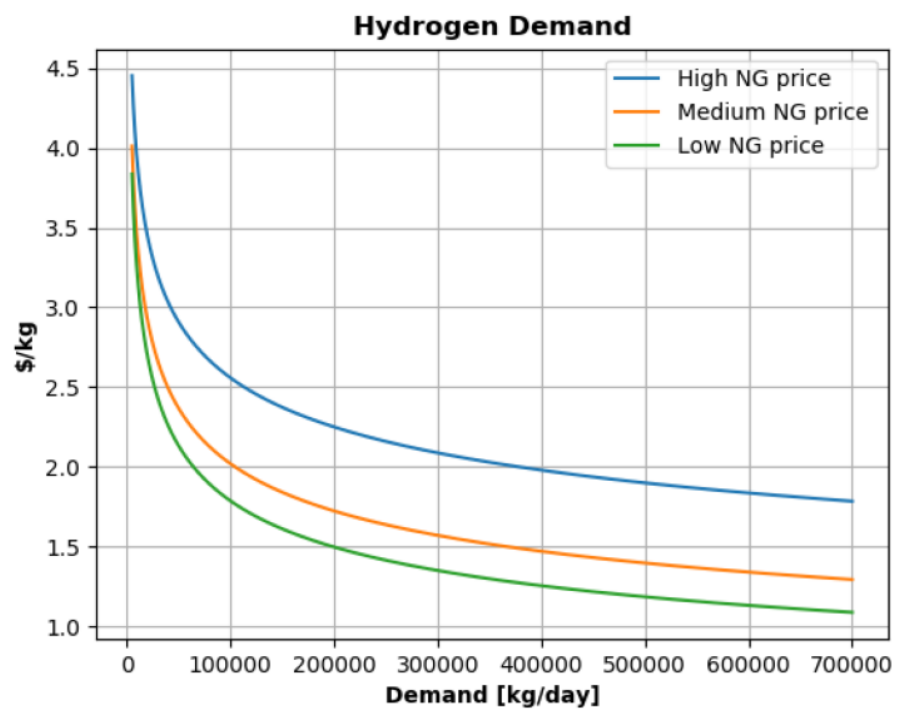

Figure 52. Price of hydrogen as a function of demand for low, medium, and high NG price assumptions (as dictated by the cost of hydrogen production via SMR) ${ }^{102}$..

Correlations from Figure 52 were plugged into the base-case model developed and previously described to express the hydrogen price as a function of the total supply quantity from the HTSE plant. This approach essentially assumes that, for a given size of the hydrogen market, the HTSE will have to compete with a new SMR plant of similar size. It does not account for the capability of an existing SMR plant to increase production, or for the ability of an SMR plant to service both the considered market alongside additional ones nearby. As a result, with the hydrogen price-to-demand correlations, the model accounts for feedback of increasing the HTSE size to supply larger demand. Figure 53 illustrates the NPV versus HTSE size when the hydrogen price-to-demand correlations are taken into account for the three selected NG prices. 


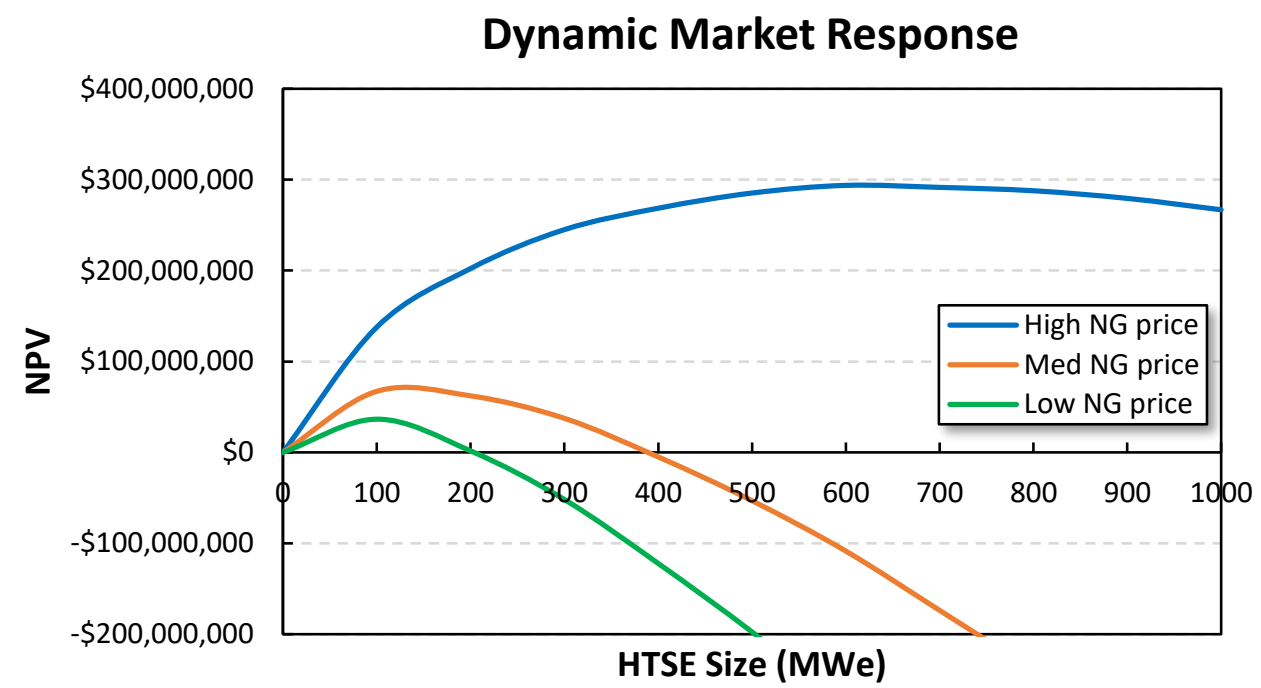

Figure 53. NPP-HTSE plant NPV as a function of HTSE size, assuming a dynamic hydrogen-marketprice response, based on competition with SMR using NG. Three price points for NG are considered for comparison.

The NPV versus HTSE size is no longer the linear behavior observed in Figure 51. As market size increases, SMR plants reach economies of scale faster than the modular HTSE plants; they therefore drive down market prices for hydrogen. On the other hand, HTSE plants are very economical in smaller markets where SMR plants are less cost efficient. As a result, the NPV values for a given NG price tends to peak at a certain market size, and these two competing effects balance each other. It is also observed that in some cases (med/low), a threshold exists beyond which the HTSE may not be economically attractive proposition. Table 20Error! Reference source not found. summarizes these different points for each NG price considered.

Table 20. HTSE size at which peak NPV is reached (optimal) and the largest HTSE size (maximum) with a positive NPV.

\begin{tabular}{|l|l|l|}
\hline & Optimal HTSE Size & Maximum HTSE Size \\
\hline Low NG Price & $50-150 \mathrm{MW}_{\mathrm{e}}$ & $\sim 200 \mathrm{MW}_{\mathrm{e}}$ \\
\hline Medium NG Price & $100-200 \mathrm{MW}_{\mathrm{e}}$ & $\sim 400 \mathrm{MW}_{\mathrm{e}}$ \\
\hline High NG Price & $600-700 \mathrm{MW}_{\mathrm{e}}$ & $>1,000 \mathrm{MW}_{\mathrm{e}}$ \\
\hline
\end{tabular}

The reported values show the range at which HTSE can compete with SMR. Under current market conditions for NG (medium price), the optimal plant size for an HTSE is approximately 100-200 MWe, and may be competitive up to $400 \mathrm{MW}_{\mathrm{e}}$. The prospects of NPP-HTSE hydrogen-production plant appear promising under the assumptions mentioned and will likely become more attractive in the future as HTSE technology improves and NPPs continue to bring their operating costs down. Again, it is important to keep in mind that these analyses, assumptions, and technologies are forward looking, preliminary estimations that are subject to change as models, technology, and assumptions improve. Large-scale HTSE demonstrations are still in the planning stages. When commissioned, they will provide much more valuable information. These analyses are not meant to be definitive, but to provide order-of-magnitude estimations of profitability to guide future research and development to catalyze change and improvement. 


\subsubsection{Sensitivity Analyses}

\subsubsection{Impact of estimated variable ranges}

This section illustrates some of the possible order-of-magnitude sensitivities of the overall plant profitability to the estimated parameters listed in Table 17. An assumed low/high end for each of these parameters was proposed. Starting from the base case of a $100 \mathrm{MW}_{\mathrm{e}}$ plant with a $\$ 1.8 / \mathrm{kg}-\mathrm{H}_{2}$ selling price, the resulting changes in NPV can be compared when one of these parameters is varied at a time while the others are held at their base-case settings. With the base conditions, a final NPV of \$786k was computed. The new NPV under each condition is illustrated in Figure 54. Varying the WACC has the most impact of all the parameters modeled.

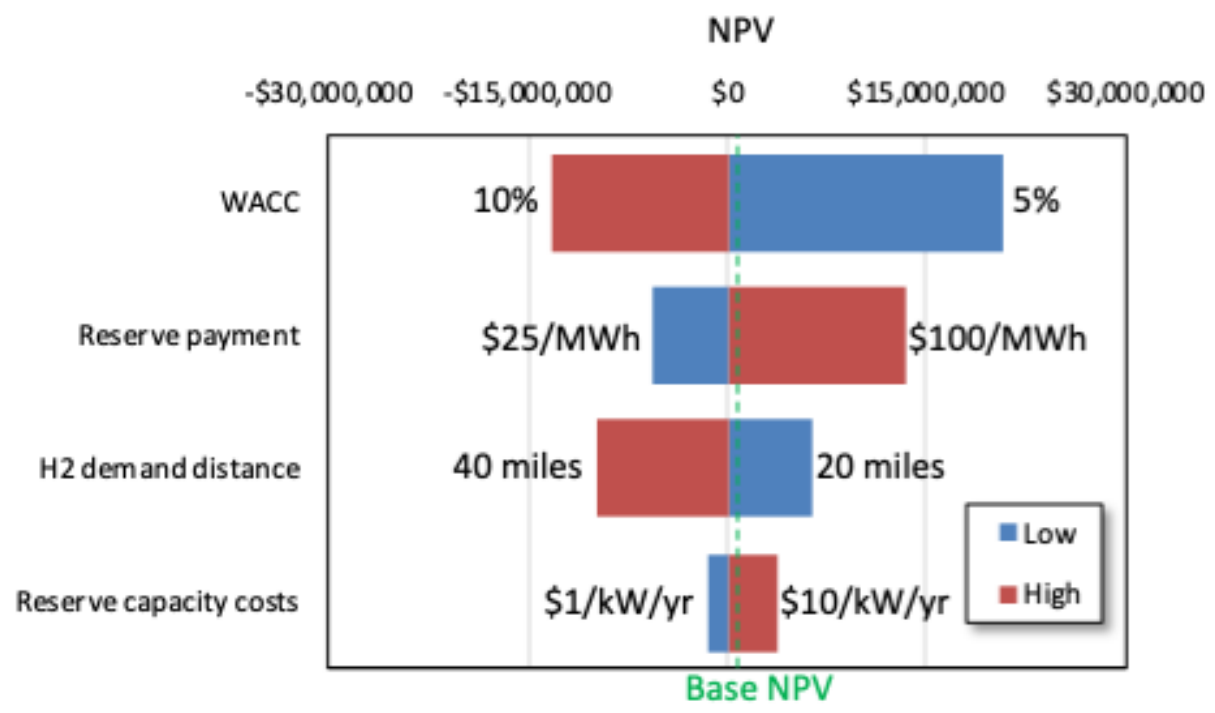

Figure 54. Sensitivity tornado chart of various low/high estimates for the different variables previously considered.

The final values are summarized in Table 21, along with a sensitivity coefficient to help estimate the NPV for variable values other than those considered. A linear approximation was found to be suitable in most cases. For instance, if the demand is at distance of 50 miles, the resulting NPV would be:

$\mathrm{NPV}(50$ mile $)=\alpha_{\text {distance }} \times(50-30)+\mathrm{NPV}(30)=-802,851 \times(20)+785,597=-\$ 15 M$

To verify the linear approximation, the 50-mile distance was manually input into the model and was found to agree within $7.6 \%$. The same analysis could be repeated for different variables, including fixed ones (e.g., NPP O\&M costs, storage time, etc.).

Table 21. NPV for the low and high estimates for the different variables previously considered.

\begin{tabular}{|l|l|l|l|}
\hline & Low & High & Sensitivity Coeff. \\
\hline Weighted average cost of capital & $\$ 20.7 \mathrm{M}$ & $-\$ 13.1 \mathrm{M}$ & $-\$ 677 \mathrm{M} / \mathrm{W}$ ACC \\
\hline Reserve capacity costs & $-\$ 1.5 \mathrm{M}$ & $\$ 3.7 \mathrm{M}$ & $\$ 0.58 \mathrm{M} /(\mathrm{kW} /$ year $)$ \\
\hline Peak electricity payment & $-\$ 5.5 \mathrm{M}$ & $\$ 13.4 \mathrm{M}$ & $\$ 0.25 \mathrm{M} /(\mathrm{MWh})$ \\
\hline $\mathrm{H}_{2}$ demand distance & $\$ 6.3 \mathrm{M}$ & $-\$ 9.7 \mathrm{M}$ & $-\$ 0.8 \mathrm{M} / \mathrm{mile}$ \\
\hline
\end{tabular}


Figure 54 highlights how the NPV is more sensitive to certain parameter than others. A decrease in the WACC of just 2.5 percentage points, can lead to a jump in NPV of over 2,500\%. It has an important compounding effect over the 20-year lifetime assumed for the HTSE. Conversely, reserve-capacity payments have a lower impact on the overall NPV due to their small contribution to the revenue for the given market conditions. The distance and peak electrical payments have a larger impact on the NPV, albeit lower than the WACC.

It should be noted that these estimates are simplistic in an attempt to be more generally applicable. Ideally, a case-by-case analysis should be conducted because regional variations can be substantial. This would allow parameters to be more-explicitly considered. For instance, future studies could use a moreaccurate framework to account for the interdependence of $\mathrm{H}_{2}$ demand and transportation costs. This could be done by considering the location of multiple sources of demand and their relative proximity to one another. A variable function of pipeline costs versus the hydrogen demand could then be constructed. Additionally, it may be useful to consider alternative transportation options, such as truck delivery. This could be in liquid- or gaseous-hydrogen form. A cost-benefit analysis would need to be conducted in more detail. This could be especially relevant if the demand for hydrogen proves too diverse (e.g., in the case of future FCEV-refilling stations).

\subsubsection{Impact of carbon tax}

The current and future price of hydrogen is tied to the NG industry, specifically the availability of NG in the U.S. market and the possible future implementation of a carbon tax or credit system. While the impact of the price of NG was considered previously, this section will investigate the implementation of carbon taxes. In theory, this could be both in the form of a traditional tax, or as a function of the cost of carbon sequestration. A low value of $\$ 25 / \mathrm{T}-\mathrm{CO}_{2}$ corresponds to the 2025 anticipated rate in the region considered $^{110}$. Some studies even envision prices as high as $\$ 100 / \mathrm{T}-\mathrm{CO}_{2}$ to reach deep decarbonization ${ }^{111}$. This will be selected as the high value.

The next step is to translate this tax to an increase in the market price for hydrogen (based on SMR production). Using estimates from NREL/TP-570-27637, the life-cycle emissions from an SMR plant can be calculated at around $8.9 \mathrm{~kg}-\mathrm{CO}_{2} / \mathrm{kg}-\mathrm{H}_{2}{ }^{112}$. For the low and high carbon-tax rates, this corresponds to an added $\$ 0.22 / \mathrm{kg}-\mathrm{H}_{2}$ and $\$ 0.89 / \mathrm{kg}-\mathrm{H} 2$ respectively.

Taking the medium price of NG from the previous section, new plots can be generated to estimate the new ranges of competitiveness of HTSE plants if carbon taxes are applied. Figure 55 plots the variation if no carbon tax is applied, the low-carbon tax is applied, and the high carbon tax is applied. Note that the 'no tax' curve corresponds to the same one from Figure 53. 


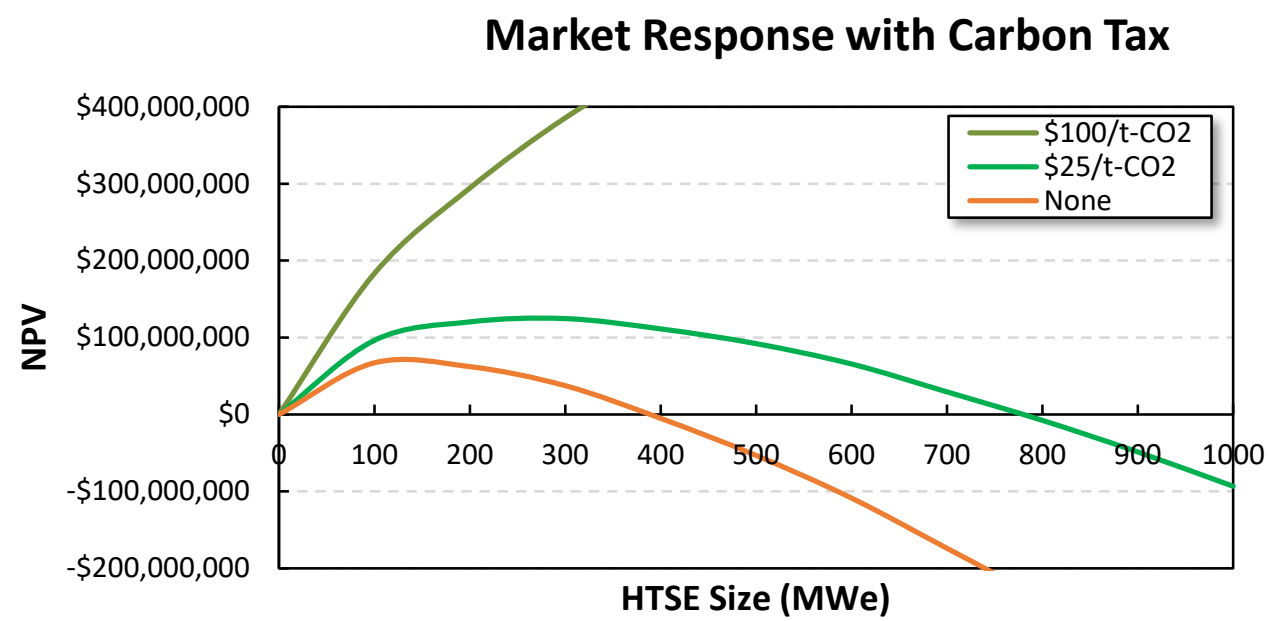

Figure 55. Impact of carbon tax on NPP-HTSE plant NPV curve as a function of HTSE size. Assumes a dynamic market response based on competition with an NG-powered SMR (at medium NG price).

The new dynamic that emerges greatly expands the profitability and the range of viable HTSE plant sizes. With $\$ 25 / \mathrm{T}-\mathrm{CO}_{2}$, the HTSE NPV remains positive up to $800 \mathrm{MW}_{\mathrm{e}}$. For the high carbon-tax rate, the range is above $1,000 \mathrm{MW}_{\mathrm{e}}$ although it should be noted that other alternative forms of hydrogen production might also become competitive under a high carbon-tax scenario. This would alter the hydrogen price curve as a function of demand. Nevertheless, this analysis still illustrates the competitiveness of an NPP-coupled HTSE for "green" hydrogen market.

Table 22 summarizes the different metrics for the two carbon tax scenarios. The range of viability of the HTSE plant greatly increases under these conditions. The case with low NG price and a low carbon tax corresponds roughly to the case with medium gas prices and no carbon tax, thereby doubling the viability range for the HTSE size. Similarly, under the current (medium) NG prices with only the low carbon-tax rate applied, the HTSE can remain competitive up to $800 \mathrm{MW}_{\mathrm{e}}$ while greatly increasing its overall profitability throughout that range. This highlights the strategic value of HTSE investments in regional markets where carbon taxes are anticipated in the near future.

Table 22. Impact of carbon tax and NG prices on HTSE economics.

\begin{tabular}{|c|c|c|c|}
\hline Carbon Tax & - & $\$ 25 / \mathrm{t}-\mathrm{CO}_{2}$ & $\$ 100 / \mathrm{t}-\mathrm{CO}_{2}$ \\
\hline $\mathrm{H}_{2}$ price at low NG for $100 \mathrm{MW}_{\mathrm{e}} \mathrm{HTSE}$ & $\$ 2.1 / \mathrm{kg}-\mathrm{H}_{2}$ & $\$ 2.3 / \mathrm{kg}-\mathrm{H}_{2}$ & $\$ 3.0 / \mathrm{kg}-\mathrm{H}_{2}$ \\
\hline $\mathrm{H}_{2}$ price at med NG for $100 \mathrm{MW}_{\mathrm{e}} \mathrm{HTSE}$ & $\$ 2.3 / \mathrm{kg}-\mathrm{H}_{2}$ & $\$ 2.5 / \mathrm{kg}-\mathrm{H}_{2}$ & $\$ 3.2 / \mathrm{kg}-\mathrm{H}_{2}$ \\
\hline $\mathrm{H}_{2}$ price at high NG for $100 \mathrm{MW}_{\mathrm{e}} \mathrm{HTSE}$ & $\$ 2.9 / \mathrm{kg}-\mathrm{H}_{2}$ & $\$ 3.1 / \mathrm{kg}-\mathrm{H}_{2}$ & $\$ 3.7 / \mathrm{kg}-\mathrm{H}_{2}$ \\
\hline Optimal HTSE Size at med NG & $100-200 \mathrm{MW}_{\mathrm{e}}$ & $\begin{array}{c}250- \\
350 \mathrm{MW}_{\mathrm{e}}\end{array}$ & $>1,000 \mathrm{MW}_{\mathrm{e}}$ \\
\hline Maximum HTSE Size at med NG & $\sim 400 \mathrm{MW}_{\mathrm{e}}$ & $\sim 800 \mathrm{MW}_{\mathrm{e}}$ & $>1,000 \mathrm{MW}_{\mathrm{e}}$ \\
\hline
\end{tabular}

\subsection{Economic Results Summary}

Overall, the analysis shows the viability of an NPP-HTSE coupling to act as a form of electricity storage during periods of peak energy demand and to also to provide an additional revenue source for a NPPs via hydrogen sales. While the model developed and presented depends on different key market 
assumptions, it does highlight the order-of-magnitude conditions under which hydrogen production may be profitable. The economic model was used to estimate the NPV of the project under different conditions: fixed hydrogen price, dynamic market response, and varying market conditions. The main findings are summarized in Table 23. With the current market assumptions, a price of hydrogen above approximately $\$ 1.8 \mathrm{~kg}-\mathrm{H}_{2} /$ year appears to show profitability. In a dynamic market, this corresponds to an approximate maximum HTSE capacity of around $400 \mathrm{MW}_{\mathrm{e}}$. If a carbon tax of $\$ 25 /$ ton- $\mathrm{CO}_{2}$ is considered, the range of profitability expands up to approximately $800 \mathrm{MW}_{\mathrm{e}}$. It should be emphasized how sensitive these estimates are to assumed parameters, including the WACC, the NPPP O\&M, the hot standby requirements, and electricity-storage requirements, etc. These need to be carefully evaluated on a case-bycase basis to determine the estimated profitability of an NPP-HTSE plant.

Table 23. Summary of key findings from the economic model evaluations.

\begin{tabular}{|l|l|}
\hline & \\
\hline Optimal HTSE size under dynamic market and medium NG prices & $100-200 \mathrm{MW}_{\mathrm{e}}$ \\
\hline Maximum profitable HTSE size in dynamic market and medium NG prices & $\sim 400 \mathrm{MW}_{\mathrm{e}}$ \\
\hline Sensitivity of NPV on the Weighted Average Cost of Capital (WACC) & $-\$ 677 / \mathrm{WACC}$ \\
\hline $\begin{array}{l}\text { Maximum profitable HTSE size in dynamic market, medium NG prices, and } \\
\text { low-carbon tax }\end{array}$ & $\sim 800 \mathrm{MW}_{\mathrm{e}}$ \\
\hline
\end{tabular}

\section{CONCLUSIONS}

In this study, nonelectric product markets have been studied generally both nationally and in diverse regions around the U.S. to ascertain the respective current and future possible market demands for nonelectric products that can be produced using the heat and electricity available from NPPs in the various regions. For each region, tables and charts have been provided showing the specific nonelectric product-demand sources and their distance from each NPP in the region. The goals of this study were to provide a sampling of the demand to the NPP operators so they could evaluate the options and make the best decision for their businesses.

The complimentary revenue model of producing non-electric products flexibly while supporting grid needs can help ensure the current fleet of LWRs can remain a sustainable pillar of the national electric grid while providing a bridge to future next generation advanced nuclear reactor deployments. LWRHybrid IES plants can provide a concentrated source of reliable clean energy that can operate flexibly producing grid electricity or non-electric products and intermediate products storage. They can support conversion of biomass and $\mathrm{CO}_{2}$ from ethanol plants to fuels and chemicals, produce fungible fuels to substitute or blend with motor gasoline or diesel, and support production of other chemicals such as methanol and formic acid. Finally, the heat requirements of these non-electric industrial process in an energy park could be provided by NPPs.

\subsection{Capacity Markets}

Capacity payments represent an attractive revenue stream, particularly in regions such as PJM where market prices have recently been as high as $>\$ 100 / \mathrm{MW}$-day. However, capacity prices have proven to be volatile and are under regulatory scrutiny as they increase as a fraction of the total wholesale electricity cost (Figure 5). The future rules, functionality, and prices of the PJM capacity market are unclear as of the publication of this report. Further, the large generating capacity of some NPPs (particularly those over $2 \mathrm{GW}$ ) may overwhelm the capacity market in some regions (e.g., NY-ISO's heavily segmented market), reducing prices or only allowing a fraction of the NPP capacity to be bid into the market. In addition, the 
storage and intermittency costs implied by electricity capacity production should be modeled and explicitly incorporated into revenue analyses.

\subsection{Markets for Direct Hydrogen and Indirect Hydrogen (DRI, Ammonia, Synfuels), Oxygen, and Polymers}

Sources of $\mathrm{CO}_{2}$ nationwide are shown in Figure 56 below. These sources of $\mathrm{CO}_{2}$ can be utilized to capture $\mathrm{CO}_{2}$ to be used for the manufacture of synfuel, formic acid and other synthetic chemicals. Ammonia $\left(\mathrm{CO}_{2}\right.$-Ammonia), steam methane reforming $\left(\mathrm{CO}_{2}-\mathrm{H}_{2}\right)$, and ethanol plants $\left(\mathrm{CO}_{2}\right.$-Ethanol $)$ are noted in the figure.

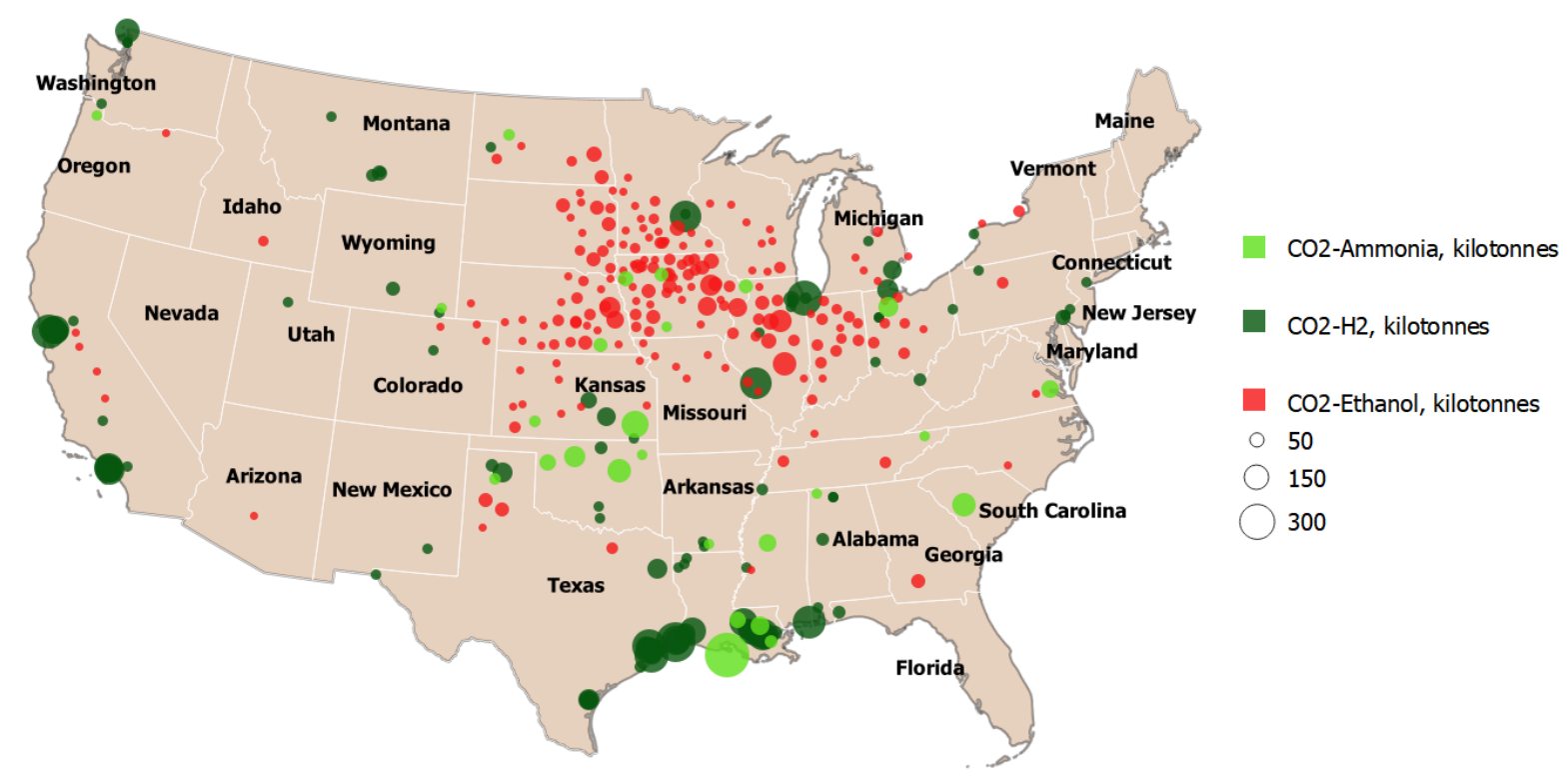

Figure 56. $\mathrm{CO}_{2}$ sources for use in synfuels production.

Table 1Table 24 below shows the approximate hydrogen prices to be competitive in the respective markets presented.

Table 24. Estimated threshold price for hydrogen to replace alternate feedstocks, by application.

\begin{tabular}{|l|l|l|}
\hline \multicolumn{1}{|c|}{ Application } & \multicolumn{1}{c|}{$\begin{array}{c}\text { Threshold Hydrogen } \\
\text { Production Price }\end{array}$} & \multicolumn{1}{c|}{ Notes } \\
\hline LD FCEVs & $\$ 2-3 / \mathrm{kg}$ & DOE targets for FCEVs \\
\hline $\begin{array}{l}\text { Medium- and HD } \\
\text { FCEVs }\end{array}$ & $\$ 2-3 / \mathrm{kg}$ & DOE targets for FCEVs \\
\hline Petroleum Refining & Up to $\$ 3 / \mathrm{kg}$ & $\begin{array}{l}\text { Competitive with SMR. No substitute } \\
\text { for hydrogen in refining process } \\
\text { (inelastic demand) }\end{array}$ \\
\hline $\mathrm{NH}_{3}$ & $\$ 2 / \mathrm{kg}$ & $\begin{array}{l}\text { Price to be competitive with imported } \\
\text { ammonia }\end{array}$ \\
\hline Synthetic FT Diesel & $\$ 1-1.5 / \mathrm{kg}$ & \begin{tabular}{l} 
Price to compete with petroleum diesel \\
\hline
\end{tabular} \\
\hline
\end{tabular}




\begin{tabular}{|l|l|l|}
\hline $\begin{array}{l}\text { Injection to NG } \\
\text { Infrastructure }\end{array}$ & $\begin{array}{l}\text { Price to compete with NG on thermal- } \\
\text { energy content, based on higher } \\
\text { heating value }\end{array}$ \\
\hline $\begin{array}{l}\text { Iron Reduction and } \\
\text { Steelmaking }\end{array}$ & $\$ 0.8-1 / \mathrm{kg}$ & $\begin{array}{l}\text { Price for hydrogen to compete with } \\
\text { NG in DRI }\end{array}$ \\
\hline
\end{tabular}

\subsection{Carbon Emissions Life-Cycle Analysis}

As expected, LCA shows that carbon emissions for products generated from nuclear energy are much lower than the incumbent processes that currently produce these nonelectric products. The case of a 30$70 \mathrm{vol} \%$ hydrogen with NG mixture in combustion turbines for power results in only an $\sim 8 \%$ reduction in carbon emissions. This is because this $30-70 \mathrm{vol} \%$ mixture is only $~ 9 \%$ hydrogen by energy; the volumetric heating value of hydrogen is approximately $30 \%$ of the corresponding heating value of NG. However, the amount of potential $\mathrm{CO}_{2}$ abatement is significant due to the large contribution of NG generating plants to the U.S. national GHG-emissions inventory. Furthermore, future turbine designs that can handle higher mixing ratios, and potentially combust $100 \%$ hydrogen, will have the potential to eliminate $\mathrm{CO}_{2}$ emissions from gas power-generation units. It is also noted that mixing hydrogen with NG in the near term is attractive compared to other new hydrogen end-use applications because it leverages the existing NG infrastructure and application end use (i.e., gas turbine); thus, little new capital investment is needed.

\subsection{Nuclear-Hydrogen Hybrid Sample Model Analysis}

With the current market assumptions, a price of hydrogen above approximately $\$ 1.8 \mathrm{~kg}-\mathrm{H} 2 /$ year appears to show profitability. In a dynamic market, this corresponds to an approximate maximum HTSE capacity of around $400 \mathrm{MWe}$. If a carbon tax of $\$ 25 /$ ton-CO2 is considered, the range of profitability expands up to approximately 800 MWe (Table 25). It should be emphasized how sensitive these estimates are to assumed parameters including the WACC, the NPPP O\&M, the hot-standby requirements, and electricity storage requirements, etc (Figure 57). These items need to be carefully evaluated on a case-bycase basis to determine the estimated profitability of an NPP-HTSE plant.

Table 25. Summary of key findings from the economic model evaluations.

\begin{tabular}{|l|l|}
\hline & \\
\hline Optimal HTSE size under dynamic market and medium NG prices & $100-200 \mathrm{MW}_{\mathrm{e}}$ \\
\hline Maximum profitable HTSE size in dynamic market and medium NG prices & $\sim 400 \mathrm{MW}_{\mathrm{e}}$ \\
\hline Sensitivity of NPV on the Weighted Average Cost of Capital (WACC) & $-\$ 677 / \mathrm{WACC}$ \\
\hline $\begin{array}{l}\text { Maximum profitable HTSE size in dynamic market, medium NG prices, and } \\
\text { low-carbon tax }\end{array}$ & $\sim 800 \mathrm{MW}$ \\
\hline
\end{tabular}




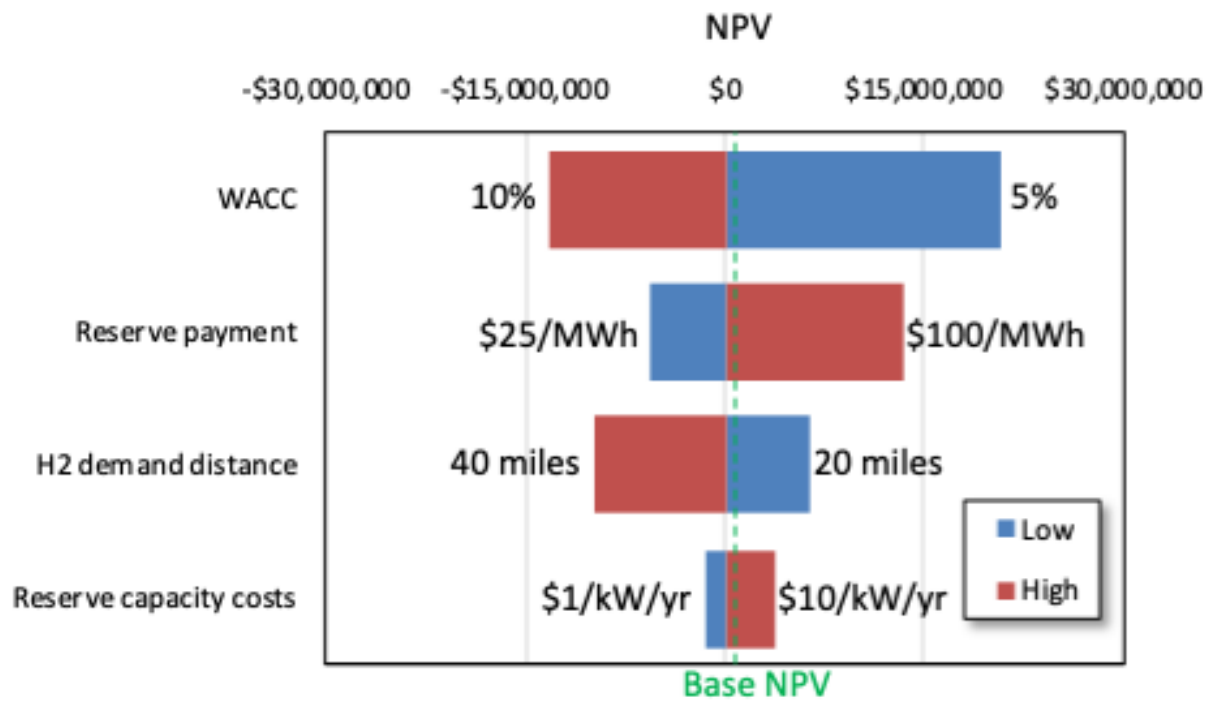

Figure 57. Sensitivity tornado chart of various low/high estimates for the different variables previously considered.

\subsection{Future Work}

Domestic fertilizer, polymer products, and iron/steel, methanol, and hydrogen fuel markets have the potential to continue rising and companies are beginning to look for cost-competitive clean products. This report focuses heavily on demand for hydrogen in and of itself and for use in making other products and chemicals such as DRI for steel production, ammonia and fertilizers, and synfuels etc). Demand for other products such as oxygen, FA, polymers and other applications are briefly discussed. An update to demand applications for heat from NPPs to form an energy park as well as more in-depth studies of synfuels and chemicals such as methanol coupling with NPPs will be the subjects of future studies. Some example steam-duty needs that could be met by NPPs include food processing, minerals concentration, plastics recycling, etc. A separate future study will also present analysis of the national discussion around creating a clean energy credit system for electricity and non-electric products produced using nuclear energy and propose various methods and school of thought for doing so. 


\section{REFERENCES}

1 Jamison, M. "Rate of Return: Regulation.” Public Utilities Research Center. Accessed on 5 March 2020 via https://bear.warrington.ufl.edu/centers/purc/docs/papers/0528_jamison_rate_of_return.pdf

2 Rodriguez, E. "Resource Assessment: Generation." (2018). Mid-Continent ISO Presentation. Accessed 27 February 2020 via https://cdn.misoenergy.org/201819\%20Winter\%20Resource\%20Assessment381789.pdf

3 Gramlich, R. \& Goggin, M. "Too Much of the Wrong Thing: The Need for Capacity Market Replacement or Reform. (Nov. 2019) Accessed 27 February 2020 via https://gridprogress.files.wordpress.com/2019/11/too-much-of-the-wrong-thing-the-need-forcapacity-market-replacement-or-reform.pdf

4 Mid-Continent ISO Report: "2019/2020 Planning Resource Auction Results.” (April 2019). Accessed 27 February 2020 via https://cdn.misoenergy.org/20190412_PRA_Results_Posting336165.pdf

5 PJM RTO Report: “Capacity Market: RPM.” (2019) Accessed 12 March 2020 via https://www.pjm.com/markets-and-operations/rpm.aspx

6 NYISO Report: "ICAP/UCAP Translation of the Demand Curve." (October 2019). Accessed 27 February 2020 via https://www.nyiso.com/documents/20142/8353973/ICAP-Translation-of-DemandCurve-Winter-2019-2020.pdf/d90d3d4d-3c77-272e-5b45-ce63c2670999

7 S\&P Global Insights. "PJM Capacity market auction could be delayed another year; uncertainty persists." (January 2020). Accessed 20 February 2020 via

https://www.spglobal.com/platts/en/market-insights/latest-news/electric-power/010820-pjm-capacitymarket-auction-could-be-delayed-another-year-uncertainty-persists

8 Federal Energy Regulatory Commission. "Order Rejecting Proposed Tariff Revisions, Granting in Part and Denying in Part Complaint, and Instituting Proceeding Under Section 206 of the Federal Power Act." (June 2018). Accessed 27 February 2020 via https://www.ferc.gov/CalendarFiles/20180629212349-EL16-49-000.pdf

9 DiSavino, S. (2020, Jan. 30). "Illinois governor wants clean energy legistlation, could push state out of PJM power grid.” Reuters. Accessed 5 February 2020 via https://www.reuters.com/article/us-usaillinois-pjm-nuclearpower/illinois-governor-wants-clean-energy-legislation-could-push-state-out-ofpjm-power-grid-idUSKBN1ZT259

10 Stephens, T., R. Levinson, A. Brooker, C. Liu, Z. Lin, A. Birkey, and E. Kontou, 2017b. Comparison of Vehicle Choice Models, ANL/ESD-17/19, Argonne National Laboratory, Argonne, IL

11 EIA, 2017a. Annual Energy Outlook 2017. DOE/EIA-0383(2017), U.S. Energy Information Administration, Washington, DC. https://www.eia.gov/outlooks/aeo/

12 CARB, 2016. Mobile Source Strategy, California Environmental Protection Agency, Sacramento, CA.

13 USCB, 2018. 'Annual Resident Population Estimates, Estimated Components of Resident Population Change, and Rates of the Components of Resident Population Change for States and Counties: April 1, 2010 to July 1, 2017.' U.S. Census Bureau. Washington, D.C. https://www2.census.gov/programssurveys/popest/datasets/2010-2017/counties/totals/co-est2017-alldata.pdf

14 USCB, 2015. 'Centers of Population by County for the 2010 Census.' U.S. Census Bureau. Washington, D.C. https://www.census.gov/geographies/reference-files/2010/geo/2010-centerspopulation.html 
15 EIA, 2018c. "Petroleum \& Other Liquids: Refinery \& Blender Net Input." https://www.eia.gov/dnav/pet/PET_PNP_INPT_A_EPOOOH_YIR_MBBL_A.htm.

16 Han, J., A. Elgowainy, M.Q. Wang, and V.B. DiVita, 2015. Well-To-Wheels Analysis of High Octane Fuels with Various Market Shares and Ethanol Blending Levels, ANL/ESD-15/10. Argonne National Laboratory, Argonne, IL.

17 Elgowainy, A., J. Han, H. Cai, M. Wang, G.S. Forman, and V.B. DiVita, 2014. "Energy Efficiency and Greenhouse Gas Emission Intensity of Petroleum Products at U.S. Refineries," Environmental Science \& Technology, Vol. 48(13):7612-7624. https://doi.org/10.1021/es5010347.

18 Elgowainy A, Mintz M, Han J, Lee U, Stephens T, Sun P, Vyas A, Zhou Y, Talaber L, Folga S, McLamore M. 'Assessment of the Potential Demand for Hydrogen in Vehicle and Industrial Applications.' Argonne National Laboratory. Lemont, Illinois. 2020.

19 Chevrier, V., 2018. "Hydrogen Uses in Ironmaking," presented at the H2@Scale Workshop, Chicago, IL (August 1). https://www.energy.gov/sites/prod/files/2018/08/f54/fcto-h2-scale-kickoff-2018-8chevrier.pdf

20 USGS, 2018, 'Metals and Minerals: U.S. Geological Survey Minerals Yearbook 2014, Volume I: Iron and Steel.' U.S. Geological Survey. Reston, Virginia. https://doi.org/10.3133/mybvI

21 USGS, 2017. Mineral Commodity Summaries 2017, U.S. Geological Survey, Reston, VA. https://minerals.usgs.gov/minerals/pubs/commodity/nitrogen/mcs-2017-nitro.pdf.

22 Ammonia Industry, 2018. "Ammonia Capacity in North America." https://ammoniaindustry.com/download-ammonia-capacity-in-north-america/

23 Market Study Report, LLC. (Feb. 2020). "Global Oxygen Market Growth 2020-2025: Summary.” Accessed 20 February 2020 via https://www.marketwatch.com/press-release/oxygen-market-size2020-global-industry-share-growth-trend-demand-top-players-opportunities-and-forecast-to-20252020-02-05

24 IBISWorld. "Oxygen and Hydrogen Gas Manufacturing in the US.” (July 2019). IBISWorld Industry Report 32512, accessed via IBISWorld Database.

25 U.S. Census Bureau. "Industrial Gases - Summary 2004.” (December 2004). MQ325C Quarterly Survey.

26 Future Market Insights, Inc. "Industrial Oxygen: Meeting Alternative Energy Demands." (July 2019). Summary accessed 1 February 2020 via https://www.prnewswire.com

27 Universal Industrial Gases, Inc. "Oxygen Properties, Uses, and Applications.” (2016). Accessed 25 January 2020 via https://www.uigi.com/oxygen.html

28 Hydrocarbon Processing. "Air Liquide starts up the world's largest oxygen production unit." (February 2018). Accessed on 20 February 2020 via https://www.hydrocarbonprocessing.com/news/2018/02/air-liquide-starts-up-the-world-s-largestoxygen-production-unit

29 Statista. "Steel Production in the United States from 2006 to 2019." (February 2020). Accessed 17 February 2020 via https://www.statista.com/statistics/209343/steel-production-in-the-us/

30 World Steel Association. "World Steel in Figures 2019: Steel Market Developments, Q2 2019." (December 2019). OECD Report JT03449878. 
31 U.S. Department of Commerce \& International Trade Administration. "Steel Industry Executive Summary: February 2020. (February 2020). Accessed 27 February 2020 via https://enforcement.trade.gov/steel/license/documents/execsumm.pdf

32 IBISWorld Market Reports. "Iron \& Steel Manufacturing in the US, Market Size 2005-2025. (2020). Accessed 10 February 2020 via https://www.ibisworld.com/industry-statistics/market-size/iron-steelmanufacturing-united-states/

33 Encyclopaedia Brittanica. "Steel.” (2011). Accessed 17 February 2020 via https://www.britannica.com/technology/steel

34 Global Syngas Technologies Council. "The Gasification Industry." (2017). Accessed 16 February 2020 via https://www.globalsyngas.org/resources/the-gasification-industry/

35 McCoy, Robert. (2005, Mar. 1). "Liquid oxygen applications from hospital to home.” Elite Healthcare. Accessed 24 February 2020 via https://www.elitecme.com/resource-center/respiratory-care-sleepmedicine/liquid-oxygen-applications-from-hospital-to-home/

36 Research and Markets, Inc. "Oxygen Therapy Equipment - Market Analysis, Trends, and Forecasts." (February 2020). Summary accessed 24 February 2020 via https://finance.yahoo.com/news/globaloxygen-therapy-equipment-market-120000074.html

37 Air Products and Chemicals, Inc. "On-Site Gas Generation.” (2014). Accessed 3 Marched 20202 via http://www.airproducts.com/Products/Gases/supply-options/onsite-gas-generation.aspx

38 Chemical Engineering Magazine. "Air Products to Build ASU for Steel Mill Expansion in Arkansas." (2019, Apr. 23). Accessed 9 March 2020 via https://www.chemengonline.com/air-products-to-buildasu-for-steel-mill-expansion-in-arkansas/?printmode $=1$

39 Federal Reserve Bank of St. Louis. "Producer Price Index by Industry: Industrial Gas Manufacturing: Oxygen." (February 2020). Accessed 8 March 2020 via https://fred.stlouisfed.org/series/PCU325120325120A

40 Alptekin, G. "Low Cost Air Separation Process for Gasification Applications." (2017, Mar. 9). Accessed 8 March 2020 via https://netl.doe.gov/sites/default/files/eventproceedings/2017/crosscutting/20170320-TrackC/20170320_1330C_Presentation_FE0026142_TDAResearch.pdf

41 Supekar, S.D., and S.J. Skerlos, 2014. "Market-Driven Emissions from Recovery of Carbon Dioxide Gas," Environmental Science \& Technology, Vol. 48(24):14615-14623. DOI: 10.1021/es503485z

42 EPA, 2017. Inventory of U.S. Greenhouse Gas Emissions and Sinks 1990-2016. Report EPA 430-R18-003, Washington, DC. https://www.epa.gov/sites/production/files/201801/documents/2018_complete_report.pdf

43 EIA, 2018d. Petroleum \& Other Liquids: U.S. Fuel Ethanol Plant Production Capacity Archives. https://www.eia.gov/petroleum/ethanolcapacity/archive/2017/index.php.

44 K. Müller, K. Brooks, and T. Autrey, "Hydrogen Storage in Formic Acid: A Comparison of Process Options," Energy \& Fuels Vol. 31 (2017), pp. 12603-12611, doi: 10.1021/acs.energyfuels.7b02997.

45 X. Lu, D.Y.C. Leung, H Wang, M.K.H. Leung, and J. Xuan, "Electrochemical Reduction of Carbon Dioxide to Formic Acid," ChemElectroChem Vol. 1 (2014), pp. 836-849, doi: 10.1002/celc.201300206. 
46 Markets and Markets, Inc. "Formic Acid Market worth \$618,80.7 Thousand by 2019." (2018).

Summary accessed 10 December 2018 via https://www.marketsandmarkets.com/PressReleases/formic-acid.asp

47 Bizzari, S.N., Blagoey, M. "CEH Marketing Research Report: Formic Acid.” (2010). Chemical Economics Handbook. SRI Consulting. Accessed 24 March 2020 via https://web.archive.org/web/20110914202313/http://www.sriconsulting.com/CEH/Public/Reports/65 9.2000/

48 BASF. "BASF raises formic acid price in Europe and the Americas." (2016, Jun. 2). BASF Press Release. Accessed 24 March 2020 via https://www.basf.com/us/en/media/news-releases/2016/06/PUS-16-067.html

49 BASF. "BASF to increase price for formic acid price in North America and South America." (2017, Jul. 3). BASF Press Release. Accessed 24 March 2020 via https://www.basf.com/us/en/media/news-releases/2016/06/P-US-16-067.html

50 Market Research Future. "Formic Acid Market Research Report - Forecast to 2027." (2018). Accessed 4 February 2020 via https://www.marketresearchfuture.com/reports/formic-acid-market-1132

51 Transparency Market Research. "Formic Acid Market - Global Industry Analysis, Size, Share, Growth, Trends, and Forecast 2017-2025.” (2018). Summary accessed 4 February 2020 via https://www.transparencymarketresearch.com/formic-acid-market.html

52 BASF. "Formic Acid: Household \& Industrial Cleaning." (2020). Promotional material. Accessed 24 March 2020 via https://www.basf.com/us/en/products/General-Business-Topics/formicacid/cleaning.html

53 OCO Chemicals. "OCOform Technology.” (December 2019). Accessed 4 February 2020 via https://ocochem.com/technology/

54 OCO Chemicals. "Formic Acid." (2019). Accessed 4 February 2020 via https://ocochem.com/formicacid/

55 Mordor Intelligence. "Formic Acid Market - Growth, Trends, and Forecast (2020-2025)." (2019). Accessed 4 February 2020 via https://www.mordorintelligence.com/industry-reports/formic-acidmarket

56 BASF. "Efficient Chemistry. Formic Acid." (2018). Accessed 4 February 2020 via https://www.basf.com/us/en/products/General-Business-Topics/formic-acid.html

57 United States Department of Agriculture. "Formic Acid - Livestock." (June 2011). Accessed 5 February 2020 via https://www.ams.usda.gov/sites/default/files/media/Formic\%20Acid\%20TR.pdf

58 Tullo, A. "Why Chemical Makers have Their Eyes on Formic Acid." (2015, Dec. 7). C\&EN Magazine. Accessed 8 February 2020 via https://cen.acs.org/articles/93/i48/Chemical-Makers-EyesFormic-Acid.html

59 U.S. Food \& Drug Administration Code of Federal Regulations Title 21. "Sec.186.1316: Formic acid." (Apr. 4 1980). Accessed 24 March 2020 via https://www.accessdata.fda.gov/scripts/cdrh/cfdocs/cfcfr/CFRSearch.cfm?fr=186.1316\&SearchTerm $=$ formic $\% 20$ acid

60 European Union Regulation 2017/940. "Document 32017R0940: Concerning the authorization of formic acid as a feed additive for all animal species." (June 1, 2017). Accessed 24 March 2020 via https://eur-lex.europa.eu/eli/reg_impl/2017/940/oj 
61 Harun, S.M.R. \& Ogneva-Himmelberger, Y. "Distribution of Industrial Farms in the United States and Socioeconomic, Health, and Environmental Characteristics of Counties." (2013) Geography Journal. https://doi.org/10.1155/2013/385893

62 BASF. "The Efficient Alternative to Acetic Acid: Formic Acid from BASF." (2011). Promotional Literature. Accessed 26 February 2020 via https://documents.basf.com

63 Muller, K., Brooks, K., \& Autry, T. "Hydrogen Storage in Formic Acid: A Comparison of Process Options.” Energy \& Fuels (2017) 31, pp. 12603-12611. DOI: 10.1021/acs.energyfuels.7b02997

64 BMT Netherlands B.V., Cargo Handbook. "Formic Acid.” (2009). Accessed 5 February 2020 via https://cargohandbook.com/index.php/Formic_acid.

65 H. Yang, J.J. Kaczur, S.D. Sajjad, and R.I. Masel, "Electrochemical conversion of CO2 to formic acid utilizing Sustainion ${ }^{\mathrm{TM}}$ membranes." (2017) Journal of CO2 Utilization, 20, pp. 208-217, doi: 10.1016/j.jcou.2017.04.011.

66 https://hdsam.es.anl.gov/index.php?content=hdsam

67 Ding, D., et al., "A novel low-thermal-budget approach for the co-production of ethylene and hydrogen via the electrochemical non-oxidative deprotonation of ethane." Energy and Environmental Science (2018) 11, 1710-1716. https://doi.org/10.1039/C8EE00645H

$68 \mathrm{Hu}$, Hongqiang et al., "Technoeconomic Analysis on an Electrochemical Nonoxidative Deprotonation Process for Ethylene Production from Ethane" (December 2019). Idaho National Laboratory, INL/EXT-19-56936, https://lwrs.inl.gov/Flexible\%20Plant\%20Operation\%20and\%20Generation/Technoeconomic_Analys is_on_an_Electrochemical_Nonoxidative_Deprotonation_Process.pdf

69 Garside, M. "Production capacity of ethylene worldwide in 2018 and 2030." (2019, Nov. 7). Statista. Accessed 26 February 2020 from https://www.statista.com/statistics/1067372/global-ethyleneproduction-capacity/

70 Garside, M. "Ethylene Production in the United States from 1990 to 2018." (2019, Oct. 10). Statista. Accessed 2 March 2020 via https://www.statista.com/statistics/974766/us-ethylene-productionvolume/.

71 Reuters Petrochemical Update. "Polyethylene investment still surging in North America (table by ICIS)" (2019). Accessed 2 March 2020 via https://analysis.petchem-update.com/engineering-andconstruction/polyethylene-investment-still-surging-north-america

72 Freedonia Group. "World polyethylene.” (2018). Summary accessed 2 February 2020 via https://www.freedoniagroup.com/industry-study/world-polyethylene-3210.htm

73 Research and Markets, Inc. "Global Polyvinyl Chloride (PVC) Market - by End-Use Industries, Products, and Region - Market Size, Demand Forecasts, Industry Trends and Updates (2018-2025)" (2017). Accessed 25 February 2020 via https://www.researchandmarkets.com/research/xxzw88/global_polyvinyl?w=4

74 Garside, M. "Production capacity of ethylene oxide worldwide in 2018 and 2023." (2019, Nov. 7). Statista. Accessed 2 March 2020 via https://www.statista.com/statistics/1065885/global-ethyleneoxide-production-capacity/

75 Reuters Petrochemical Update. "3 core challenges the US energy transformation created." (2019, Mar. 27). Accessed 30 January 2020 via https://analysis.petchem-update.com/supply-chain-logistics/3core-challenges-us-energy-transformation-created 
76 Lewandowski, S. "Ethylene - Global.” (2016). I.H.S. Markit. Accessed 25 February 2020 via https://cdn.ihs.com/www/pdf/Steve-Lewandowski-Big-Changes-Ahead-for-Ethylene-Implicationsfor-Asia.pdf

77 U.S. Energy Information Administration, “Annual Energy Outlook with Projections to 2050.” (2020, Jan. 29.) Accessed 30 January 2020 via https://www.eia.gov/outlooks/aeo/

78 Barry, D. "Polyethylene exports \& the U.S. \& China Trade War." (2019, Oct. 21) OpisBlog. Accessed 20 February 2020 via http://blog.opisnet.com/polyethylene-and-trade-war

79 Mid-Ohio Valley Regional Council, et al. "Ethane Cracker Supply Chain Market Study." (2014). Accessed 18 February 2020 via https://www.apeg.com/wpcontent/uploads/2015/06/Ethane_Cracker_Supply_Chain_-_Public_Final_-_May_2015.pdf

80 Reuters Petrochemical Update. "US downstream expansion momentum continues with new project announcements." (2019, Jul. 23). Accessed 18 February 2020 via https://analysis.petchemupdate.com/engineering-and-construction/us-downstream-expansion-momentum-continues-newproject-announcements

81 Schneider, K. "Shell Sees New Role for Former Steel Region: Plastics." (2019, Mar. 26). The New York Times. Accessed 20 February 2020 via https://www.nytimes.com/2019/03/26/business/shellpolyethylene-factory-pennsylvania.html

82 Plastics Insight. "LDPE (Low-Density Polyethylene): Production, Price, and its Properties." (2019). Accessed 20 February 2020 via https://www.plasticsinsight.com/resin-intelligence/resin-prices/ldpe/

83 Polymer Properties Database. "Plastics Industry Facts". Accessed 13 February 2020 via https://polymerdatabase.com/polymer\%20classes/Plastics\%20Industry\%20Facts.html

84 Hickey, D. "Strategies for Today’s U.S. Plastics Industry Site Selection” (2016, Dec. 6) Trade and Industry Development. Accessed 2 February 2020 via https://www.tradeandindustrydev.com/industry/plastics/strategies-today\%E2\%80\%99s-us-plasticsindustry-site-selec-12336

85 PwC. "Transporting Growth: Delivering a Chemical Manufacturing Renaissance." (2017, Mar.) American Chemistry Council Report. Accessed 15 March 2020 via https://www.americanchemistry.com/Transporting-Growth-Delivering-a-Chemical-ManufacturingRenaissance.pdf

86 Bailey, T. "Prospects to Enhance Pennsylvania's Opportunities in Petrochemical Manufacturing." (2017, Mar. 21 ) HIS Markit. Accessed 20 February 2020 via https://teampa.com/wpcontent/uploads/2017/03/Prospects_to_Enhance_PAs_Opportunities_in_Petrochemical_Mfng_Report _21March2017.pdf

87 Carr, C. "Global Propylene Market: Motivated to Change.” (2014, Sep.). IHS Asia Chemical Conference. Accessed 8 March 2020 via http://cdn.ihs.com/www/pdf/asia-chem-conf/Carr.pdf

88 Wood Mackenzie Chemicals. "Propylene Global Supply Demand Analytics Service. (2018, Mar. 4). Accessed 8 March 2020 via https://www.woodmac.com/news/editorial/propylene-global-supplydemand-analytics-service/

89 United States Nuclear Regulatory Commission. "List of Operating Nuclear Power Reactors (by Location or Name).” (2019). Accessed 10 October 2019 via https://www.nrc.gov/info-finder/reactors/ 
90 Ammonia Industry. "Ammonia Plants in North America." (2018). Ammonialndustry.org. Accessed 15 November 2019 via https://ammoniaindustry.com/ammonia-plants-in-north-america/

91 A Barrel Full Oil \& Gas Wiki. "U.S. Oil Refineries” (2015, Sep. 29). ABarrelFull.Wikidot. Accessed 20 January 2020 via http://abarrelfull.wikidot.com/us-refineries

92 AIM Market Research. "Steel Plants of North America”. (2010). Accessed 25 January 2020 via https://www.steel.org/Making\%20Steel/ /media/Files/AISI/Making\%20Steel/2010_SteelPlant_North America_HypocycloidVersion6.ashx accessed on 25 January, 2020.

93 Global Syngas Technologies Council, "Worldwide Syngas Database.” (2020). GlobalSyngas.org. Accessed 1 November 2019 via https://www.globalsyngas.org/resources/world-gasificationdatabase/

94 Garside, M. "Projection of the U.S. petroleum refinery end-use market output from 2020 to 2024." (2020, Feb. 4). Statista. Accessed 26 February 2020 via https://www.statista.com/statistics/407793/forecast-for-petroleum-refinery-end-use-market-output-inthe-united-states/

95 Garside, M. "Projection of the U.S. petroleum refinery end-use market output from 2020 to 2024." (2020, Feb. 4). Statista. Accessed 26 February 2020 via https://www.statista.com/statistics/407793/forecast-for-petroleum-refinery-end-use-market-output-inthe-united-states/

96 Gallen, T. "Phoenix leads U.S. cities in population growth, new Census data shows." (2019, May 23.) Phoenix Business Journal. Accessed 10 March 2020 via https://www.bizjournals.com/phoenix/news/2019/05/23/phoenix-leads-us-in-population-growth-newcensus.html.

97 Nicla, A. "Does Arizona really use less water now than it did in 1957?” (2019, Feb. 12). AZ Central/The Republic. Accessed 10 March 2020 via https://www.azcentral.com/story/news/local/arizona-environment/2019/02/12/arizona-waterusage-state-uses-less-now-than-1957/2806899002/

98 Arizona Water Facts. “Arizona’s Water Supplies.” Accessed 9 March 2020 via http://www.arizonawaterfacts.com/water-your-facts

99 Arizona Department of Water Resources. “AZ's Groundwater Management Act of 1980.” (2016, Nov. 18). Accessed 10 March 2020 via https://new.azwater.gov/news/articles/2016-18-11

100 Karabelas, A.J., et al., "Analysis of specific energy consumption in reverse osmosis desalination processes.” Desalination (2018), 431 (1):15-21. https://doi.org/10.1016/j.desal.2017.04.006

101 Installed Capacity Monthly Auction Summaries: View Monthly Auction Summary. (Winter 20192020). New York ISO. Accessed 26 February 2020 via http://icap.nyiso.com/ucap/public/auc_view_monthly_detail.do

102 Frick, K. et al., "Evaluation of Hydrogen Production Feasibility for a Light Water Reactor in the Midwest." (September 2019). Idaho National Laboratory, INL/EXT-19-55395, OSTI1569271. DOI: $10.2172 / 1569271$

103 NREL, “Annual Technology Baseline: 2018 ATB Cost and Performance Summary”, url: https://atb.nrel.gov/electricity/2018/summary.html, accessed 9/11/2019. 
104 Westinghouse Electric Corporation (1984). The Westinghouse Pressurized Water Reactor Nuclear Power Plant

105 B. Yildiz, K.J. Hohnholt, and M.S. Kazimi, "Hydrogen Production Using High-Temperature Steam Electrolysis Supported by Advanced Gas Reactors with Supercritical CO2 Cycles," Nuclear Technology, Vol. 155 No. 1 (2006), 1-21, doi: 10.13182/NT06-A3742

106 McCollum DL, Ogden JM. Techno-Economic Models for Carbon Dioxide Compression, Transport, and Storage and Correlations for Estimating Carbon Dioxide Density and ViscosityUCD-ITS-RR-06$14,2006$.

107 M. Mohitpour, H. Golshan, and A. Murray, Pipeline Design and Construction, ASME Press, New York, NY, 2003.

108 S.T. McCoy, and E.S. Rubin, "An engineering-economic model for pipeline transport of CO2 with application to carbon capture and storage," International Journal of Greenhouse Gas Control Vol. 2 (2008), pp. 219-229.

109 D.J. Zigrang, and N.D. Sylvester, "Explicit approximations to the solution of Colebrook friction factor equation," AIChE J. Vol. 28, No. 3 (1982), pp. 514-515.

110 Xcel Energy, Upper Midwest Integrated Resource Plan 2020-2034, Northern States Power Company Docket No. E002/RP-19-368, (2019).

111 D. McCollum et al., "Energy investment needs for fulfilling the Paris Agreement and achieving the Sustainable Development Goals", Nature Energy, vol. 3, 589-599 (2018).

112 P. Spath and M. Mann, "Life Cycle Assessment of Hydrogen Production via Natural Gas Steam Reforming”, National Renewable Energy Laboratory, NREL/TP-570-27637, (2001). 